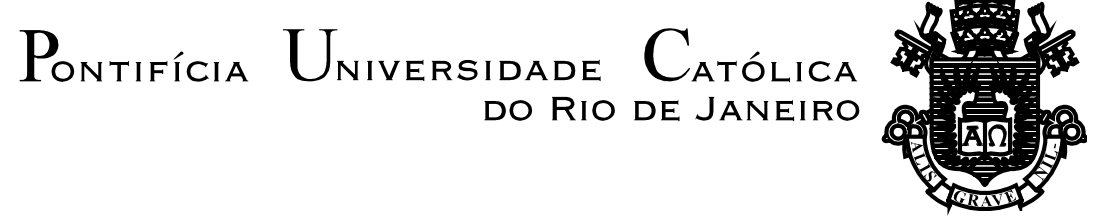

Danielle Novais Uchôa

A compreensão de orações relativas com pronomes resumptivos no Português do

Brasil

Tese de Doutorado

Tese apresentada ao Programa de Pós-graduação em Estudos da Linguagem da PUC-Rio como requisito parcial para obtenção do grau de Doutor em Letras/Estudos da Linguagem.

Orientadora: Profa. Erica dos Santos Rodrigues Co-orientadora: Profa. Cilene Rodrigues

Rio de Janeiro

Fevereiro de 2019 
Pontifícia Universidade Católica $_{\text {a }}$

DO RIO DE JANEIRO

Danielle Novais Uchôa

\title{
A compreensão de orações relativas com pronomes resumptivos no Português do Brasil
}

\begin{abstract}
Tese apresentada como requisito parcial para obtenção do grau de Doutor pelo Programa de Pós-graduação em Estudos da Linguagem da PUC-Rio. Aprovada pela Comissão Examinadora abaixo assinada.
\end{abstract}

Profa. Erica dos Santos Rodrigues

Orientador e presidente

Departamento de Letras - PUC-Rio

Profa. Cilene Aparecida Nunes Rodrigues

Co-orientadora

Departamento de Letras - PUC-Rio

Profa. Letícia Maria Sicuro Corrêa

Departamento de Letras - PUC-Rio

Profa. Marina Rosa Ana Augusto

UERJ

Prof. Eduardo Kenedy Nunes Areas

UFF

Profa. Mercedes Marcilese

UFJF

Profa. Monah Winograd

Coordenadora Setorial do Centro de Teologia

e Ciências Humanas - PUC-Rio

Rio de Janeiro, 14 de fevereiro de 2019. 
Todos os direitos reservados. É proibida a reprodução total ou parcial do trabalho sem autorização da universidade, da autora e da orientadora.

\section{Danielle Novais Uchôa}

Graduou-se em Letras (Português / Inglês e respectivas literaturas) na Universidade Federal de Juiz de Fora em 2009 e obteve o título de Mestra em Linguística em 2013.

Ficha Catalográfica

Uchôa, Danielle Novais

A compreensão de orações relativas com pronomes resumptivos no português do Brasil / Danielle Novais Uchôa ; orientadora: Erica dos Santos Rodrigues ; co-orientadora: Cilene Aparecida Nunes Rodrigues. -2019.

211 f. : il. color. ; $30 \mathrm{~cm}$

Tese (doutorado)-Pontifícia Universidade Católica do Rio de Janeiro, Departamento de Letras, 2019.

Inclui bibliografia

1. Letras - Teses. 2. Orações relativas. 3. Pronomes resumptivos. 4. Compreensão da linguagem. 5. Processamento sintático. 6. Custo derivacional. I. Rodrigues, Erica dos Santos. II. Rodrigues, Cilene Aparecida Nunes. III. Pontifícia Universidade Católica do Rio de Janeiro. Departamento de Letras. IV. Título.

CDD: 400 
Para meus pais, Carlos e Rosana, pelo amor, dedicação e apoio incondicionais. 


\section{Agradecimentos}

A Deus, por ter me dado saúde, força e resiliência para conseguir concluir este trabalho.

Aos meus pais, por toda doação, incentivo e amor, responsáveis por eu ter conseguido chegar até aqui.

Às minhas orientadoras, Erica e Cilene, pelo conhecimento partilhado e compreensão com minhas falhas.

Ao CNPq e à PUC-Rio, pelos auxílios concedidos, sem os quais este trabalho não poderia ter sido realizado.

À banca examinadora, pelo olhar cuidadoso e ricas contribuições com esta tese.

Ao Eduardo Kenedy, pelas contribuições com a parte metodológica, especialmente, pelo ensinamento do teste qui-quadrado.

À Chiquinha, pelo profissionalismo e doçura com que sempre nos tratou. Suas palavras, em um momento difícil, foram decisivas para que eu não desistisse.

Ao CAEd, pelo incentivo dado através das dispensas semanais, que viabilizaram o Doutorado.

Ao IFRJ, em especial aos colegas da equipe de Línguas Estrangeiras, por todo o incentivo, parceria, carinho e excelente clima de trabalho, sem os quais o caminho se tornaria muito mais difícil.

A cada aluno, do passado e do presente, pelas trocas proporcionadas, sorrisos sinceros, estímulo e animação constantes, que me energizavam sempre, tornando meus dias mais leves, agradáveis e me motivando a sempre fazer o meu melhor.

Ao ex-presidente Lula, por tudo que fez pelos professores e pela educação, dandonos incentivo para formação e condições de termos acesso a uma educação gratuita e de qualidade.

Ao DreamteamPUC, pelos momentos de aprendizado, trocas de experiências, mas, principalmente, de descontração. 
Às “Anas", sempre próximas, acompanhando de perto essa trajetória e me incentivando nos momentos difíceis (e foram muitos). Ana Paula Leal, minha amiga de longa data, obrigada por sua presença constante, por sua torcida, por nossos papos e amizade sincera. Ana Paula Jakubów, minha inspiração, agradeço pela paciência com que sempre me ouviu, me deu forças e me ensinou. Sua ajuda na reta final com os experimentos foi essencial. Obrigada! Sem vocês, com certeza seria muito mais difícil.

A todos os meus amigos, pela amizade, força, torcida, risadas e momentos alegres, que não me deixaram abater ao longo de todos esses anos.

Aos meus familiares, por serem sempre tão unidos, presentes e terem tanto orgulho de mim.

A cada professor que passou em minha vida, pela contribuição que cada um deixou para que eu hoje chegasse até aqui. Vocês são brilhantes!

A cada participante que, com muita boa vontade, contribuíram para a concretização desta pesquisa.

Ao Renê Forster, por toda ajuda com a programação do experimento e recrutamento de participantes.

À Yasmin, que sem nem mesmo me conhecer, ajudou a conseguir muitos participantes para os experimentos, sendo essencial para que eu conseguisse concluir a pesquisa.

À Andressa Christine, pela valiosa ajuda (e muita paciência) com a programação dos experimentos. Sem você, eu não teria conseguido. Obrigada!

À Aline Fonseca, pela boa vontade demonstrada em ajudar na programação dos experimentos, dirimindo minhas dúvidas.

Ao João, meu companheiro e cúmplice, por toda a paciência que teve em ouvir meus desabafos, em aguentar minhas crises de estresse e por ter sido tão compreensivo, principalmente na reta final, com os meus constantes "tenho que estudar". Obrigada por me achar muito melhor do que verdadeiramente eu sou, me passando confiança, tranquilidade e incentivo, fazendo-me sentir merecedora deste 
título. Obrigada pelos vários cafés enquanto eu estudava, por me fazer relaxar quando eu estava esgotada e pelos muitos momentos felizes juntos. Por você, eu não desisti. 


\section{Resumo}

Uchôa, Danielle Novais; Rodrigues, Erica dos Santos (Orientadora), Cilene Aparecida Nunes (Co-orientadora). A compreensão de orações relativas com pronomes resumptivos no Português do Brasil. Rio de Janeiro, 2019. 211p. Tese de Doutorado - Departamento de Letras, Pontifícia Universidade Católica do Rio de Janeiro.

Esta tese investiga a compreensão de orações relativas resumptivas no Português do Brasil. O trabalho busca articular teoria linguística de orientação gerativista e processamento linguístico. Estudos de orientação gerativista, baseados, principalmente, em julgamentos de aceitabilidade, sustentam que os pronomes resumptivos envolvem custo nas interfaces (pronomes como estratégias de último recurso - ROSS, 1967; SELLS, 1984; SHLONSKY, 1992; HORNSTEIN, 2001; GROLLA, 2005). Do ponto de vista do processamento, sua ocorrência está relacionada a situações não planejadas (FERREIRA e SWETS, 2005; CORRÊA et al., 2018) e a contextos de alto custo, que tornam o antecedente menos acessível (ARIEL, 1999): distância entre elemento anafórico e antecedente, posição sintática do elemento anafórico, natureza e características do antecedente, etc. No Português do Brasil, os pronomes resumptivos permanecem como estrutura marginal, embora sejam licenciados em diferentes posições sintáticas (TARALLO, 1988; LESSADE- OLIVEIRA, 2008,2009; RIBEIRO, 2009; MIRANDA, 2005). Pretendemos investigar, por meio de uma metodologia experimental, possíveis fatores de custos associados à compreensão dessas estruturas. Reportam-se quatro experimentos: dois de julgamento de aceitabilidade e dois de escuta automonitorada. No primeiro, contrastou-se a aceitabilidade de relativas padrão $v s$ resumptivas na posição de sujeito e em outras posições mais complexas (objeto direto, objeto preposicionado e genitivo), em que há sempre um elemento interveniente (FRIEDMANN, BELLETTI e RIZZI, 2009). No segundo experimento, foi avaliada a aceitabilidade de relativas padrão, cortadoras e resumptivas nas posições de oblíquo e genitivo. Os resultados mostraram uma preferência pela estratégia padrão. Resumptivos foram altamente rejeitados na posição de sujeito e apresentaram notas bem distribuídas pela escala nas demais posições investigadas. O terceiro e quarto experimentos avaliaram o processo de compreensão de relativas padrão e 
resumptivas (experimento 3) e de cortadoras e resumptivas (experimento 4) em função da posição sintática ocupada pelo elemento anafórcio (pronome/lacuna) e da distância linear (curta, média e longa) entre os elementos correferentes na compreensão de relativas. Nesses dois experimentos, observou-se que os pronomes resumptivos tornam o processamento mais rápido quando fatores adicionais de custo são evidentes (intervenção de DP e/ou distância linear). Na posição de sujeito, em que não há efeito de interveniência, os resumptivos tornaram o processamento mais fácil em distância longa, convergindo com os estudos de corpora (MOLLICA, 2003) e com o princípio da acessibilidade (ARIEL, 1999). Na posição de objeto direto, foram encontrados resultados significativos para distância curta (quando há somente o DP interveniente) e distância longa. Nas posições de oblíquo e genitivo, relativas resumptivas apresentam tempo de escuta menor e, à medida que a distância linear aumenta, o processamento de resumptivas se torna mais rápido que das cortadoras. Em conjunto, os experimentos mostram que, a despeito de os resumptivos terem sido menos aceitos que a estratégia padrão, eles não parecem comprometer o processo de compreensão, podendo servir como elementos facilitadores em situações de alta demanda, em termos de distância linear e de pouca acessibilidade do antecedente.

\section{Palavras-chave}

Orações relativas; pronomes resumptivos; compreensão da linguagem; processamento sintático; custo derivacional. 


\section{Abstract}

Uchôa, Danielle Novais; Rodrigues, Erica dos Santos (Advisor), Cilene Aparecida Nunes (Co-advisor), The comprehension of relative clauses with resumptive pronouns in Brazilian Portuguese. Rio de Janeiro, 2019. 211p. Tese de Doutorado - Departamento de Letras, Pontifícia Universidade Católica do Rio de Janeiro.

This thesis investigates the comprehension of resumptive relative clauses in Brazilian Portuguese. The study seeks to reconcile a linguistic theory grounded in generativism and language processing. Generativism-guided studies based mainly on acceptability judgment tasks support that resumptive pronouns have cost at the interfaces (pronouns as last resource strategy - ROSS, 1967; SELLS, 1984; SHLONSKY, 1992; HORNSTEIN, 2001; GROLLA, 2005). From the point of view of processing, its occurrence is related to non-planned situations (FERREIRA e SWETS, 2005; CORRÊA et al., 2018) and to high-cost contexts, being licensed in whenever the antecedent less accessible (ARIEL, 1999), when distance between the anaphoric element and its antecedent is too long, syntactic position of the anaphoric element, the nature and features of the antecedent etc. In Brazilian Portuguese, resumptive pronouns remain a marginal structure, although they are licensed in different syntactic positions (TARALLO, 1988; LESSA DE OLIVEIRA, 2008,2009; RIBEIRO, 2009; MIRANDA, 2005). We intend to investigate, through an experimental methodology, the possible costs of resumptives related to comprehension. We conducted four experiments: two acceptability judgment tasks, and two self-paced listening tasks. In the first one, it was contrasted the acceptability of standard vs resumptive strategies in subject position and in other more complex positions (direct object, prepositional object, and genitive) in which there is always an intervening element (FRIEDMANN, BELLETTI e RIZZI, 2009). In the second experiment, the acceptability of standard, chopped and resumptive relatives in oblique and genitive positions was evaluated. The results showed a preference for the standard strategy. Resumptives were highly rejected in subject position and had quite spread values through the scale in the other examined positions. The third and fourth experiments evaluated the comprehension process of standard and resumptive relatives (experiment 3 ) and of chopped and resumptive relatives (experiment 4), according to the syntactic position of the pronoun/gap and 
to the linear distance (short, middle, long) between the coreferent elements. In these two experiments, it was observed that resumptive pronouns seem to make processing faster when additional cost factors are added (intervention effects and linear distance). In the subject position, in which there is no intervention effect, resumptives made processing easier in long distance contexts. This result is in accordance with corpora studies (MOLLICA, 2003) and with the accessibility principle (ARIEL, 1999). In the direct object position, it was found significative results on short and long distance. In oblique and genitive positions, resumptive relatives have shorter listening times than chopped relatives, and as linear distance increases, the processing of resumptive relatives become faster than that of chopped ones. Taken together the experiments show that, despite resumptives being less acceptable than standard strategy, they do not compromise the process of comprehension, being able to act as a facilitator element in high-demand situations, in terms of linear distance and little accessibility of the antecedent.

\section{Keywords}

Relative clauses; resumptive pronouns; language comprehension; syntactic processing; derivational cost. 


\section{Sumário}

1. Introdução

2. Estudos diacrônicos acerca das orações relativas com pronomes resumptivos

3. Propostas teóricas para a estrutura das orações relativas restritivas 34

3.1 Head external analysis - Hipótese da adjunção com movimento de operador

3.2 Raising analysis - Hipótese da complementação com movimento de $\mathrm{N}$

3.3 Matching Analysis - Hipóteses da adjunção com dois núcleos idênticos

3.4 Em síntese

3.5 Estratégias de relativização no Português Brasileiro 46

3.5.1 Orações relativas restritivas padrão 46

3.5.2 Orações relativas restritivas não padrão 47

3.5.2.1 As orações relativas cortadoras 49

3.5.2.2 As orações relativas resumptivas 50

3.5.2.3 O status do pronome resumptivo 53

3.6 Custos associados à derivação de relativas: uma possível análise para as estratégias de relativização do PB

4. Processamento das orações relativas

4.1 Custos associados às orações relativas

4.1.2 Processamento de orações relativas com resumptivos

4.1.2.1 Estudos em compreensão

4.1.2.2 Estudos em produção

4.1.2.3 A hipótese da acessibilidade do antecedente 102

4.2 Custos associados ao processamento de relativas resumptivas 
5. Experimentos 107

5.1 Experimento 1: julgamento de aceitabilidade 108

5.1.1 Método 109

5.1.2 Hipóteses e previsões 112

$\begin{array}{ll}5.1 .3 \text { Resultados } & 115\end{array}$

5.1.4 Discussão dos resultados 119

5.2 Experimento 2: julgamento de aceitabilidade 121

5.2.1. Método 122

5.2.2. Hipóteses e previsões 123

$\begin{array}{ll}5.2 .3 \text { Resultados } & 124\end{array}$

5.2.4 Discussão dos resultados 127

5.2.5 Discussão geral dos experimentos 1 e $2 \quad 128$

5.3 Experimentos 3 e 4: escuta automonitorada 129

5.3.1 Experimento 3: relativas de sujeito e objeto direto 130

5.3.1.1 Método 131

5.3.1.2 Hipóteses e previsões 134

5.3.1.3 Resultados 135

5.3.1.4 Discussão dos resultados 139

5.3.2 Experimento 4: relativas de oblíquo e genitivo 141

5.3.2.1 Método 142

5.3.2.2 Hipóteses e previsões 143

5.3.2.3 Resultados 144

5.3.2.4 Discussão dos resultados 149

5.3.2.5 Análise dos tempos de reação para todas as posições sintáticas 151

5.3.2.6 Discussão geral dos experimentos 3 e 4

5.4 Em síntese 155

6.Considerações finais 158

$\begin{array}{ll}\text { 7. Referências bibliográficas } & 163\end{array}$

$\begin{array}{ll}\text { Anexos } & 173\end{array}$ 


\section{Lista de Figuras}

Figura 1: Imagem usada no experimento de Ferreira e Swets (2005) 91

Figura 2: Imagem usada no experimento de Corrêa et al (2018) 


\section{Lista de gráficos}

Gráfico 1: Valor percentual para cada nota por condição experimental - experimento 1

Gráfico 2: Proporção de notas por posição sintática - experimento 1

Gráfico 3: Proporção de notas por tipo de relativa testada experimento 1

Gráfico 4: Valor percentual para cada nota por condição experimental - experimento 2

Gráfico 5: Proporção de notas por posição sintática - experimento 2

Gráfico 6: Proporção de notas por tipo de relativa - experimento 2

Gráfico 7: Médias dos tempos de escuta do segmento crítico em função da posição sintática - experimento 3

Gráfico 8: Médias dos tempos de escuta do segmento crítico em função da distância linear - experimento 3

Gráfico 9: Médias dos tempos de escuta do segmento crítico em função do tipo de relativa - experimento 3

Gráfico 10: Médias dos tempos de escuta do segmento crítico em função da posição sintática e da distância linear- experimento 3

Gráfico 11: Médias dos tempos de escuta do segmento crítico em função da distância linear - experimento 4

Gráfico 12: Médias dos tempos de escuta do segmento crítico em função do tipo de relativa - experimento 4

Gráfico 13: Médias dos tempos de escuta do segmento crítico em função da posição sintática e distância linear - experimento 4

Gráfico 14: Médias dos tempos de escuta do segmento crítico em função da posição sintática e tipo de relativa - experimento 4

Gráfico 15: Médias dos tempos de escuta do segmento crítico em função do tipo de relativa e distância linear - experimento 4

Gráfico 16: Médias dos tempos de escuta do segmento crítico em função da posição sintática- experimentos 3 e 4 
Gráfico 17: Médias dos tempos de escuta do segmento crítico em função da distância linear- experimentos 3 e 4

Gráfico 18: Médias dos tempos de escuta do segmento crítico em função da posição sintática e distância linear-experimentos 3 e 4 


\section{Lista de tabelas}

Tabela 1: Distribuição das estratégias de relativização ao longo dos séculos (LESSA-DE-OLIVEIRA, 2009)

Tabela 2: Distribuição de relativas resumptivas por posição sintática ao longo dos séculos (LESSA-DE-OLIVEIRA, 2009)

Tabela 3: Condições experimentais do experimento de Keffala (2013) 79

Tabela 4: Exemplos de estímulos usados por condição experimental experimento 1

Tabela 5: Informações sobre perfil dos participantes - experimento 1110

Tabela 6: Quantidade de julgamentos por condição experimental experimento 1

Tabela 7: Exemplos de estímulos usados por condição experimental experimento 2

Tabela 8: Informações sobre perfil dos participantes - experimento 2123

Tabela 9: Quantidade de julgamentos por condição experimental experimento 2

Tabela 10: Percentual de notas agrupadas para cortadoras e resumptivas em posição de oblíquo e genitivo

Tabela 11: Exemplos de estímulos usados por condição experimentalexperimento 3

Tabela 12: Estatística descritiva para relativas de sujeito e objeto direto - experimento 3

Tabela 13: Exemplos de estímulos usados por condição experimentalexperimento 4

Tabela 14: Estatística descritiva para relativas de objeto preposicionado e genitivo - experimento 4 


\section{Lista de abreviaturas e siglas}

CGen: Cortadora de Genitivo

CObl: Cortadora de Oblíquo

COMP: Complementizador

CP: Complementizer Phrase

D: Determinante

DP: Determiner Phrase

Gen: Genitivo

LF: Logical Form

$\mathrm{N}$ : Noun

NP: Noun frase

OBL: Oblíquo

OI: Objeto Indireto

OPrep: Objeto Preposicionado

PB: Português do Brasil

PF: Phonetic form

PGen: Padrão de Genitivo

PGen: Padrão de Genitivo

PM: Programa Minimalista

PObl: Padrão de Oblíquo

POD: Padrão de Objeto Direto

POPrep: Padrão de Objeto Preposicionado

PP: Prepositional Phrase

PSuj: Padrão de Sujeito

RGen: Resumptiva de Genitivo

RGen: Resumptiva de Genitivo

RObl: Resumptiva de Oblíquo

ROD: Resumptiva de Objeto Direto

ROPrep: Resumptiva de Objeto Preposicionado

RSuj: Resumptiva de Sujeito

SOV: Sujeito, Objeto, Verbo

Spec: Specifier

TP: Tense Phrase 
"Olhar para trás após uma longa caminhada pode fazer perder a noção da distância que percorremos, mas se nos detivermos em nossa imagem, quando a iniciamos e ao término, certamente nos lembraremos o quanto nos custou chegar até o ponto final, e hoje temos a impressão de que tudo começou ontem. Não somos os mesmos, mas sabemos mais uns dos outros". 


\section{Introdução}

Este trabalho tem como objeto de pesquisa as orações relativas restritivas resumptivas. Buscando um diálogo entre Psicolinguística e Teoria Linguística, pretendemos investigar essas estruturas, tanto em termos do custo computacional e de representação nas interfaces, associado à derivação dessas estruturas, quanto no que tange aos fatores que podem afetar o seu processamento on-line e representar custo na compreensão de sentenças.

O estudo se insere na linha de pesquisa "Língua e Cognição: Representação, Processamento e Aquisição da Linguagem", do Programa de Pós-Graduação em projetos das professoras doutoras Erica dos Santos Rodrigues e Cilene Rodrigues denominados "Processamento sintático e questões de interpretação na interface sintaxe-semântica" (2014-atual) e "Pronomes: estruturação e desestruturação" (2017-atual), respectivamente.

A investigação de orações relativas numa perspectiva do processamento remonta às pesquisas da década de 60 , período em que Psicolinguística e Teoria Linguística de orientação gerativista mantiveram estreito diálogo (CHOMSKY e MILLER, 1963; CHOMSKY, 1965; MILLER e ISARD, 1964). O interesse no tópico, inicialmente associado, por um lado, a questões relativas à recursividade e produtividade linguísticas, e, por outro, a limites da memória de trabalho, tem-se ampliado ao longo dos anos, com discussões voltadas para fatores de ordem sintática que podem afetar o custo de processamento de diferentes tipos de relativas, como, por exemplo, efeitos de intervenção (GRILLO, 2009; FRIEDMANN, BELLETTI e RIZZI, 2009), fatores relativos à acessibilidade na memória de trabalho e recuperação do elemento relativizado (ARIEL, 1999), e também para a relação entre custo de processamento associado à possibilidade de diferentes estratégias de relativização em algumas línguas, como ocorre no Português Brasileiro (PB), em que convivem, ao lado da forma padrão, duas estratégias nãopadrão - a relativa cortadora e a relativa resumptiva - esta última focalizada particularmente em nosso estudo.

As orações relativas, em termos descritivos, caracterizam-se por serem encabeçadas por um pronome relativo e por modificarem uma expressão nominal 
antecedente na oração principal, mantendo com essa expressão uma relação sintático-semântica. Esse núcleo nominal ou antecedente é, por sua vez, associado, no interior da oração relativa, a uma posição vazia, uma lacuna ou mesmo um pronome resumptivo (no caso de algumas línguas).

Semanticamente, as relativas atuam delimitando ou restringindo o domínio de referência do antecedente. No exemplo (1), fica claro que a ação expressa na oração relativa aplica-se a um $\mathrm{N}$ específico, único.

No âmbito das relativas restritivas, Tarallo (1983) reconhece no PB três tipos de estratégias de relativização: padrão, cortadora e resumptiva. A denominada padrão apresenta uma lacuna na posição do correferente ao nome relativizado, como em (1):

(1) O livro ${ }_{1}$ de que eu preciso para estudar] esgotou nas livrarias

As estratégias denominadas de cortadoras e de resumptivas são consideradas não canônicas do ponto de vista da tradição gramatical, e, portanto, associadas a contextos mais informais e de fala (TARALLO, 1983).

As relativas cortadoras são aquelas em que a preposição que encabeça o sintagma preposicionado contendo o elemento anafórico dentro da relativa é apagada, gerando, assim, uma lacuna de sintagma preposicionado. São passíveis de ocorrer em estruturas envolvendo posse, como em (2), estruturas genitivas, e em estruturas com verbos que pedem complementos preposicionados, como em (3), objeto indireto, e (4) oblíquo. Nos exemplos abaixo apresentamos o contraste entre a relativa cortadora (a) e a relativa padrão (b).

(2) a. A menina 1 [que [o cabelo $t_{1}$ ] é muito comprido] foi apelidada de Rapunzel.

b. A menina 1 [cujo [ cabelo $t_{1}$ ] é muito comprido] foi apelidada de Rapunzel.

(3) a. O paciente ${ }_{1}$ [que a enfermeira deu o remédio errado $t_{1}$ ] foi internado b. O paciente $_{1}$ [pro qual a enfermeira deu o remédio $t_{1}$ ] errado foi internado. 
(4) a. A passageira 1 [que o comissário discutiu $t_{1}$ ] processou a companhia aérea.

b. A passageira 1 [com quem o comissário discutiu $t_{1}$ ] processou a companhia aérea.

Dados obtidos a partir de estudos diacrônicos (TARALLO, 1983; LESSADE-OLIVEIRA, 2008; 2009) atestam a preferência, no PB, pela estratégia cortadora, em estruturas envolvendo sintagmas preposicionados. No âmbito dos estudos gerativistas, afirma-se que tal preferência reside no fato de, nesses contextos sintáticos, a estratégia padrão ser considerada estranha à competência linguística natural do falante, que opta, então, pela utilização de estratégias alternativas, que são mais naturais e econômicas. É o que observa Kenedy (2007; 2008), a partir de dados experimentais, ao postular uma hipótese de acordo com a qual o Sistema Computacional (SC) não é capaz de gerar naturalmente relativas preposicionadas de pied-piping, preferindo derivações de estruturas menos custosas, como as cortadoras e resumptivas. Conclusão semelhante é reportada por Corrêa (1998), para quem a relativização de sintagmas preposicionados ocorre mediante aprendizagem formal, sendo associada a contextos mais formais.

Nas orações relativas resumptivas, a posição da lacuna é ocupada por um pronome resumptivo, isto é, um pronome pessoal que concorda em gênero, número e pessoa com a expressão nominal relativizada, como em (5).

(5) O livro 1 que eu preciso dele $\underline{\text { para }}_{1}$ pastudar esgotou nas livrarias 1.

No PB, a ocorrência do pronome resumptivo em orações relativas é atestada em diferentes posições sintáticas, conforme estudos conduzidos por Tarallo (1983) e Lessa-de-Oliveira (2008; 2009a)2, embora com distribuição distinta, sendo mais comuns e frequentes em determinadas funções sintáticas do que em outras. Estudo de dados de fala expõe fatores que favorecem a ocorrência da estratégia resumptiva, como determinados traços semânticos do antecedente, função sintática do elemento anafórico e distância entre elemento anafórico e antecedente (MOLLICA, 1997;2003).

1 No capítulo 3 apresentaremos algumas propostas teóricas para a estrutura dessas orações. 2 Cf. capítulo 2. 
Dentro do arcabouço teórico no qual o presente trabalho ancora-se, a Teoria Gerativa e, mais especificamente seu desenvolvimento mais atual, o Programa Minimalista (CHOMSKY, 1995) considera-se que a estratégia resumptiva envolve maior custo derivacional, com operações extras nas interfaces (HORNSTEIN, 2001; 2007; GROLLA, 2005a), sendo, por isso, considerada como estratégia de último recurso, utilizada somente quando necessária para garantir a convergência da derivação.

Sob o escopo do Programa Minimalista, o princípio que norteia a derivação de estruturas linguísticas é o da Economia, pelo qual estruturas mais econômicas devem ser preferidas. Dessa forma, a estratégia resumptiva, por envolver maior custo computacional em relação à estratégia de movimento (padrão), seria utilizada somente quando determinadas condições necessárias à convergência da derivação não podem ser satisfeitas.

Isso é claramente evidenciado no caso de línguas como o inglês, em que se aceitam pronomes resumptivos apenas em posições não porosas para movimento, como no caso de configurações de ilhas sintáticas (MCDANIEL e COWART, 1999; ALEXOPOULOU e KELLER, 2003; KEFALLA, 2013; HAN et al., 2012). O que ocorre neste caso é que o pronome interrogativo não pode se mover, pois o movimento viola uma barreira sintática, conforme ilustrado no exemplo 6 a seguir, em que a oração relativa introduzida por "that" bloqueia o movimento.

(6) Who does Mary meet the people that will fire $t /$ him? (ALEXPOULOU e KELLER, 2007)

'Quem Maria conhece as pessoas que demitirão t/ele?'

No Português, a ocorrência de resumptivos não se restringe a contextos de ilhas, já que podem ocorrer também dentro de constituintes não-ilhas, conforme visto nos exemplos (2) - (4). No entanto, resultados de estudos de processamento conduzidos com adultos e crianças em PB (cf. capítulo 4) indicam que os falantes não fazem uso irrestrito de relativas resumptivas, na medida em que fatores associados a custo de processamento parecem influenciar o processo de formulação dessas estruturas e também na compreensão. 
No que diz respeito ao processamento, a ocorrência de pronomes resumptivos em orações relativas parece estar atrelada a situações de alto custo para o processador linguístico. Esse custo, como será detalhado no capítulo 4, está relacionado, em especial, à necessidade de manutenção e recuperação do antecedente da relativa na memória de trabalho (GIBSON, 2000; 2005). Alguns fatores podem, entretanto, tornar esse custo ainda maior. Dentre eles, tem-se considerado questões relativas à quantidade e à natureza do material interveniente entre a posição de origem do elemento relativizado e o núcleo da relativa (GIBSON, 1998; 2000; GORDON et al., 2001). A ocorrência de resumptivos no PB parece, pois, estar associada a esses contextos em que é capaz de reduzir o custo associado ao processamento dessas sentenças.

Uma questão que tem sido abordada nos trabalhos em processamento diz respeito a possíveis diferenças no uso de resumptivos na produção e na compreensão de sentenças. Embora frequentes na produção (POLINSKY, et al. 2013; FERREIRA e SWETS, 2005; MIRANDA, 2008), resultados de testes envolvendo julgamento de aceitabilidade apontam que os pronomes resumptivos não atuam como elementos facilitatórios, causando um estranhamento no ouvinte (ALEXOPOULOU e KELLER, 2003; POLINKSY et al., 2013; KEFALLA, 2013).

Este trabalho motiva-se pela constatação de que, apesar da extensa literatura sobre as orações relativas resumptivas, poucos trabalhos foram desenvolvidos em PB. Diversos estudos de viés sociolinguístico, teórico e experimental pretendem descortinar possíveis aspectos envolvidos no fenômeno da resumpção, mas carecese, ainda, de uma investigação mais detalhada sobre esses aspectos. Dessa forma, esta pesquisa busca contribuir para melhor entendimento desse fenômeno linguístico, examinando pontos ainda em aberto, a partir de uma discussão sobre o papel dos pronomes resumptivos em uma perspectiva teórica e de processamento em tempo real. Assim, buscamos contribuir também para a aproximação entre as áreas de teoria formal da Gramática psicolinguística.

Conduzimos dois experimentos de julgamento de aceitabilidade para avaliar se e em quais contextos falantes nativos do PB consideram esses elementos naturais da gramática da língua em questão. Ainda, dois experimentos de escuta automonitorada pretendem testar se os pronomes resumptivos tornam o processamento de relativas mais fácil em função da distância linear e da posição sintática ocupada pelo elemento anafórico (lacuna / pronome resumptivo). 
Assume-se como hipótese, com base na literatura sobre o tópico, que os pronomes resumptivos são estruturas de alto custo, aplicadas como último recurso para salvar derivações não convergentes e também manifestas diante de demandas de processamento, conforme será detalhado nos capítulos 3 e 4 . Trata-se de um fenômeno com relevância tanto para as pesquisas em teoria da gramática quanto para a área de processamento. Estudos experimentais (reportados no capítulo 4) mostram que pronomes resumptivos são implementados em tempo real sob determinadas condições de processamento, tornando-o menos custoso, mas por outro lado "estranhados" / não bem avaliados pelo sistema da gramática. Esse desalinhamento entre sistema de gramática e sistema de processamento, captado pelas tarefas off-line e online apresentadas no capítulo 5, suscita a discussão sobre a distinção entre Gramática e mecanismos de processamento (LEWIS e PHILLIPS, 2015, p.31). Conforme será visto no capítulo 5, os resultados sugerem que o parser não parece exibir as mesmas restrições identificadas pela Gramática.

Assim, nosso objetivo geral é buscar determinar possíveis fatores que interferem na compreensão de orações relativas com resumptivos. A partir do objetivo geral, temos como objetivos específicos:

(i) Analisar possíveis custos atrelados a cada estratégia de relativização (padrão, cortadora e resumptiva).

(ii) Contrastar a aceitabilidade dos três tipos de relativa.

(iii) Investigar a aceitabilidade dos resumptivos em diferentes posições sintáticas.

(iv) Investigar em que medida distância linear e posição sintática do elemento anafórico afetam o processamento de relativas com resumptivos.

(v) Contribuir para a discussão acerca da relação entre gramática e processamento em tempo real.

(vi) Apresentar um panorama de trabalhos desenvolvidos sobre resumptivos.

A tese tem a seguinte organização: no próximo capítulo apresentamos, em linhas gerais, alguns estudos diacrônicos que oferecem contribuições importantes sobre as orações relativas restritivas resumptivas. No capítulo 3 , sintetizamos as principais análises teóricas para a estrutura de orações relativas canônicas e não canônicas. Em seguida, no quarto capítulo, apresentamos estudos realizados no 
âmbito do processamento acerca das orações relativas e, especialmente, das resumptivas, destacando os possíveis fatores que parecem afetar a produção e/ou compreensão dessas estruturas. No capítulo cinco, encontram-se os pressupostos metodológicos adotados, a descrição dos experimentos realizados e os resultados obtidos. O capítulo 6 apresenta uma discussão geral dos resultados e proposta de experimentos futuros. 


\section{2}

\section{Estudos diacrônicos acerca das orações relativas com pronomes resumptivos}

Embora este trabalho pretenda explorar, através de uma metodologia experimental, o processamento de orações relativas resumptivas sob o escopo da Psicolinguística, estudos conduzidos em uma perspectiva sociolinguística oferecem importantes contribuições à descrição das orações relativas no PB, apresentando um panorama histórico da distribuição dessas estruturas. Além disso, alguns desses estudos apontam para fatores que podem estar relacionados ao emprego das diferentes estratégias de relativização (fatores intra e extra-linguísticos). Neste capítulo, portanto, reportamos alguns importantes estudos nesta área.

Em um trabalho seminal, Tarallo (1983) relata a existência de outras duas estratégias de relativização em $\mathrm{PB}$, além da padrão: a cortadora e a resumptiva, esta última ocorre em diversas posições sintáticas, como sujeito; objeto direto; objeto indireto; oblíquo e genitivo, sendo preferida, no entanto, nestas três últimas posições, ou seja, em posições mais baixas / encaixadas.

Tarallo busca também desvelar, dentre outras coisas, fatores linguísticos e não linguísticos que determinam a escolha de um dos três tipos de estratégia de relativização. Para isso, constituiu corpora para análise sincrônica, contendo gravações realizadas entre os anos de 1981 e 1982, com 40 informantes pertencentes a diferentes faixas etárias e classe social3, textos de mídia constituídos por entrevistas, novelas, etc. no século XX-e diacrônica - cartas e peças teatrais dos séculos XVIII e XIX. Foram analisados fatores sintáticos e semânticos que influenciam na utilização do pronome.

Os dados obtidos revelam primeiramente que a ocorrência de relativas resumptivas é muito pequena, tanto nos dados sincrônicos $(9,5 \%)$, quanto nos diacrônicos $(3,5 \%)$.

No que concerne a fatores sintáticos, a hipótese do autor é que, a partir da hierarquia da acessibilidade defendida por Keenan e Comrie (1977), posições sintáticas mais baixas, como genitivo, objeto indireto e oblíquo, favorecem a

3 Metade dos falantes pertenciam a classes sociais mais baixas. 
ocorrência de pronomes resumptivos, enquanto que posições mais altas, como objeto direto e sujeito, desfavorecem esse tipo de pronome. De fato, os dados diacrônicos examinados pelo autor mostram uma preferência pelo emprego do pronome nas posições mais baixas, que têm, ao longo dos três períodos investigados (séculos XVIII, XIX e XX), um aumento na utilização da estratégia resumptiva. A posição de sujeito, que se apresentava como a menos favorecedora à ocorrência de pronome nos séculos XVIII e XIX, correspondendo a pouco mais de $1 \%$ do total de ocorrências, apresenta, no século XX, um crescimento na frequência de ocorrência dessa estratégia, chegando próximo dos $10 \%$. Já na posição de objeto direto, verifica-se exatamente o contrário: há uma redução no uso de pronomes resumptivos no século XX, que correspondem a apenas 2,6\% do total de ocorrência.

A estratégia resumptiva mostra-se mais frequente que a cortadora até a segunda metade do século XIX, período em que se nota uma mudança no sistema pronominal do $\mathrm{PB}$, e essa estratégia passa a ser a mais utilizada, correspondendo à $27,9 \%$ do total de relativas produzidas, em oposição à ocorrência de $5 \%$ das resumptivas (TARALLO, p. 206,1983). Considerando a frequência de uso das três estratégias de relativização somente nas posições sintáticas preposicionadas, observou-se que a cortadora é mais frequente que a resumptiva na primeira metade do século XIX $(5,1 \%$ x 3,4\%). Na passagem deste período para a segunda metade do século, para essas posições sintáticas, houve um crescimento expressivo das estratégias não canônicas e uma queda da padrão, que perde sua preferência4.

Tarallo apresenta outros fatores que contribuem para maior ou menor ocorrência de pronomes resumptivos. Relativas de encaixe final (ou à direita) favoreceriam, de acordo com o autor, a ocorrência de resumptivos, já que a distância entre o antecedente e a posição da lacuna/pronome é maior. Quando há também material interveniente entre o NP relativizado e a oração relativa, o processamento se torna difícil e há mais chance de ocorrência de um pronome resumptivo. A complexidade da sentença também pode favorecer a expectativa de emprego de pronomes resumptivos, de modo que, quanto mais orações encaixadas houver entre o antecedente e a oração relativa, maior será a distância e, consequentemente, maior a probabilidade de ocorrência do pronome resumptivo. Esses dados conversam com aqueles obtidos por estudos em processamento (cf. capítulo 4) e sinalizam, segundo

4Segunda metade do século XIX: relativas padrão: 19,2\%; resumptivas: $31 \%$; cortadoras: 90,6\%. Dados de Tarallo (1983, p.207). 
Tarallo (1983, p. 103), que pronomes resumptivos são empregados pelo falante como recurso para recuperar a estrutura sintática a ser produzida, de modo a não se perder quanto ao que está sendo dito.

Há também fatores semânticos que atuam de forma a determinar a utilização da estratégia resumptiva. Examinando os corpora criados, o autor observou que a natureza do NP antecedente ao pronome também exerce influência na escolha pela estratégia padrão ou resumptiva. Assim, em contextos onde o NP relativizado tem traços [+ humano], [+singular] e [+indefinido], o pronome resumptivo tende a ocorrer com mais frequência. Resultado semelhante foi encontrado por Mollica (1997) em análise de uma amostra representativa da classe semi-escolarizada carioca, que mostrou uma tendência de a estratégia copiadoras ocorrer com antecedentes de traço [+ humano], [+indefinido], [+coletivo] e distantes do elemento anafórico.

Tarallo também examinou a influência de fatores de background social, como classe social e registro linguístico e concluiu que falantes oriundos de classes sociais mais baixas fazem mais uso da estratégia resumptiva, sendo a diferença, quando comparada com classes mais altas (média e alta), significativamente relevante $(\mathrm{p}<.05)$. Na análise do uso das três estratégias de relativização para todas as posições sintáticas por cada grupo social, percebeu-se uma preferência em todos os grupos pela estratégia cortadora nas posições mais baixas e uma recusa pela estratégia copiadora na posição de objeto direto. Em relação à variação de registro, percebeu-se que, em situações de fala espontânea, o resumptivo tende a emergir com mais frequência, sugerindo que a utilização desses elementos está relacionada a contextos de pouco planejamento da fala, conforme atestado em estudos de produção (ver capítulo 4).

Em um teste de julgamento de aceitabilidade que contrastou diferentes estratégias de relativização em função da classe social e função sintática, o autor obteve indícios de que tanto no grupo de falantes de classe média, quanto no de classe alta, os pronomes resumptivos são menos aceitos que a forma padrão ou cortadora em todas as posições testadas, principalmente nas posições de sujeito e de objeto direto. Nessas, falantes de classe média preferiram o objeto nulo e os de

\footnotetext{
$5 \mathrm{O}$ termo copiadora é comumente usado em trabalhos da Sociolinguística para se referir à estratégia resumptiva, nomenclatura adotada por nós ao longo deste trabalho. Referiremo-nos ao nome copiadora quando este termo for assim empregado por algum autor.
} 
classe mais alta, os clíticos. Apesar dessa baixa aceitabilidade, verificou-se que a aceitabilidade aumenta nas posições de objeto indireto, oblíquo e genitivo.

Em uma outra tarefa, os participantes pertencentes à classe média e alta foram instruídos a unir duas orações em uma única sentença, em diferentes posições sintáticas. A expectativa do autor era que emergissem diferentes estratégias de relativização nas posições mais baixas. Para as relativas de sujeito e de objeto direto, ambos os grupos optaram pela forma padrão. Já para as funções de objeto indireto, oblíquo e genitivo, houve diferença entre os grupos: aqueles de classe mais alta rejeitaram o resumptivo nas funções de oblíquo e genitivo, priorizando a estratégia de apagamento (cortadora). Já o grupo pertencente à classe média priorizou o uso dos resumptivos na função de genitivo em detrimento das outras duas possibilidades de relativização.

Norteando-se por esse trabalho, Lessa-de-Oliveira (2008; 2009a) amplia os dados de Tarallo, comparando-os a cartas da segunda metade do século XVIII. A tabela abaixo, retirado de Lessa-de-Oliveira (2009a, p. 66) sintetiza os dados obtidos6:

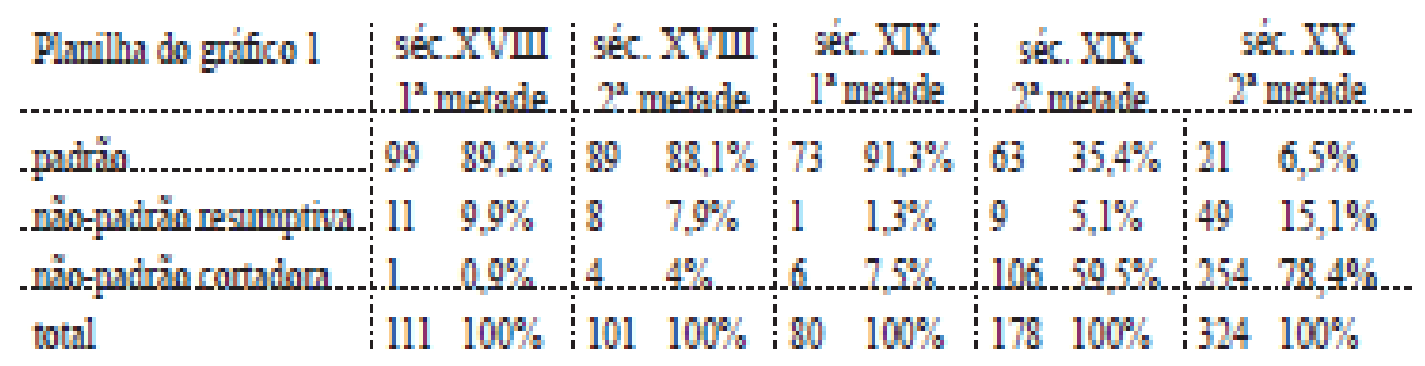

Tabela 1: Distribuição das estratégias de relativização ao longo dos séculos (LESSADE-OLIVEIRA, 2009)

Em relação à distribuição dos resumptivos em diferentes posições sintáticas, a autora apresenta a seguintes tabela, em RF indica a porcentagem de relativas resumptivas encontradas:

\footnotetext{
6 Cumpre observar que nos dados apresentados por Tarallo (1983) e Lessa-de-Oliveira (2009), encontram-se contabilizadas juntas, dentro do grupo das relativas resumptivas, as relativas encabeçadas por DP e por PP.
} 


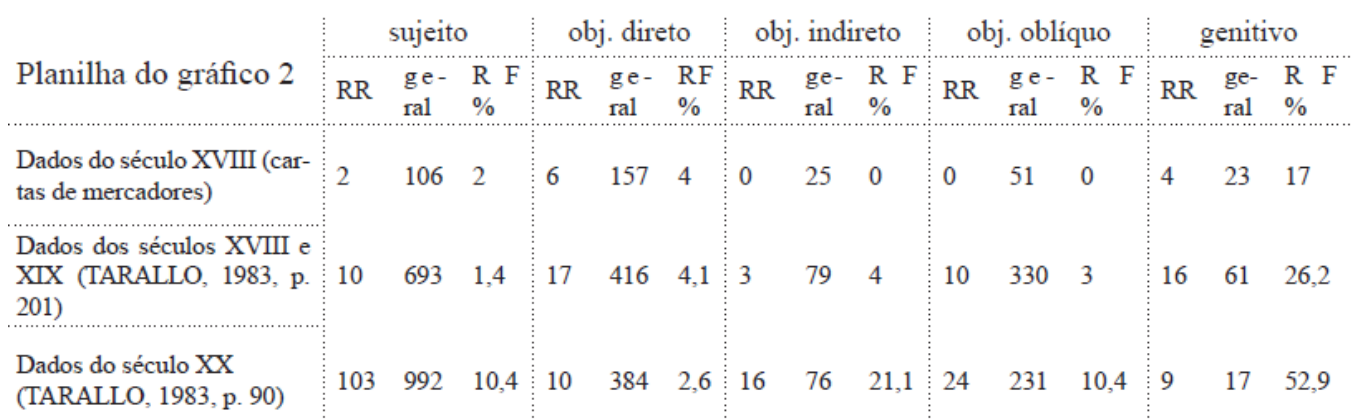

Tabela 2: Distribuição de relativas resumptivas por posição sintática ao longo dos séculos (LESSA-DE-OLIVEIRA, 2009)

A posição de genitivo foi a que mais favoreceu a ocorrência de resumptivos, em todos os séculos investigados. Com exceção da posição de objeto direto, a frequência de resumptivos aumentou ao longo dos séculos.

A partir da argumentação de Tarallo sobre a preferência por pronome nulo em detrimento do pleno na posição de objeto direto, a autora busca explicar o porquê do aumento de resumptivos na posição de sujeito. Seguindo Galves (1986 apud LESSA-DE-OLIVEIRA, 2009), que defende que em Português do Brasil o objeto nulo é altamente frequente, ao passo que a posição de sujeito preenchida é preferida em relação ao sujeito nulo, a autora defende que ocorreu uma modificação no sistema pronominal do PB entre os séculos XIX e XX. Essa mudança consistiu na perda do parâmetro pro-drop de marcação morfológica pelo verbo. Essa perda das marcas flexionais estaria levando o Português do Brasil a deixar de ser uma língua de sujeito nulo e a necessitar de explicitar o sujeito por meio de um pronome ou de um nome.

Além disso, outras mudanças são verificadas ao longo do tempo. Na posição de genitivo, no século XX, o pronome possessivo "seu" foi substituído por "de+ resumptivo". Já nas de objeto indireto, o oblíquo "lhe" deu lugar para também um sintagma preposicionado. Assim,

não deve ter sido por acaso que as relativas resumptivas nessas duas posições apresentaram o maior índice de aumento de frequência, destacando-se essas posições como as grandes favorecedoras da relativa resumptiva. Ou seja, esses dados mostram uma assimilação do padrão oblíquo. (LESSA-DE-OLIVEIRA, 2009 a, p. 75) 
Assim, a autora conclui que houve uma alteração no comportamento da relativa resumptiva, resultante de mudanças no sistema pronominal e flexional do $\mathrm{PB}$, tendo se tornado, de forma geral, mais frequentes ao longo do tempo.

Em suma, os trabalhos de Tarallo (1983) e Lessa-de-Oliveira (2009) mostram que, das três estratégias de relativização possíveis em $\mathrm{PB}$, a cortadora é a preferida. Os pronomes resumptivos, apesar de serem licenciados em diferentes posições sintáticas, apresentam frequência distinta entre elas, sendo mais comuns em posições baixas, em especial, em posições de complementos oblíquos e de objeto preposicionado. Essas conclusões, a partir da análise de corpus do século XX e de análise diacrônica, conversam com os trabalhos de viés experimental e com a sintaxe gerativa, como veremos nos capítulos a seguir.

Em outro estudo de corpora, com análise em tempo real, que busca diálogo com o trabalho de Tarallo (1983) está o de Mollica (2003), que se concentra no emprego de orações relativas em um lapso temporal de 20 anos. A autora analisa o uso da anáfora pronominal do NP antecedente nas posições sintáticas de sujeito, complemento preposicionado e complemento não preposicionado. Os dados coletados foram analisados a partir de fatores sociais, como escolaridade, sexo e idade, além de variáveis estruturais, tais como traço de animacidade do referente, função sintática e a distância entre o NP referente e o relativizador.

Os dados observados possibilitam definir os fatores que influenciam em sua ocorrência. Houve predomínio da estratégia copiadora quando há distância entre o referente e o pronome relativo, como no exemplo a seguir, observado nos corpora da autora: "a menina de cabelo louro com lacinho vermelho na cabeça que ela quebrou a perna ontem". Mollica pontua que, nesse caso, o emprego do elemento anafórico relaciona-se à demanda de processamento, facilitando a recuperação do antecedente da relativa, ou ainda, à desambiguização em relação ao antecedente, como no exemplo a seguir, também retirado dos corpora da autora, em que o pronome-cópia7 ("ele") deixa claro que o antecedente é "o professor" e não "escola": "o professor de matemática era o melhor da minha escola que eu estudei com ele na $8^{\mathrm{a}}$ série".

7Termo utilizado pela autora e por trabalhos em Sociolinguística para se referir ao pronome resumptivo. Utilizaremos aqui essa nomenclatura, para mantermo-nos fiel à linha teórica ao qual o estudo de Mollica se insere. 
Reafirmando o que já foi atestado em outros estudos (TARALLO, 1983; MOLLICA, 1997), constatou-se maior emprego da cópia quando o antecedente é do tipo [+humano].

Em relação à posição sintática, Mollica observou maior incidência da estratégia copiadora na posição de sujeito, indicando uma possível modificação de parâmetro na língua portuguesa, que revela uma tendência de a posição de sujeito ser preenchida, assim como mostra Lessa-de-Oliveira (2009).

Quanto ao fator escolaridade, Mollica observa que em contexto de maior distância, a estratégia de cópia tende a ocorrer, independentemente do grau de escolaridade. A escola, de acordo com a autora, monitoraria os casos mais estigmatizados, em que não há interferência do fator distância. Nesses contextos, de distância zero, a forma preferida é a cortadora.

No cruzamento das variáveis escolaridade e função sintática, notou-se que, em contextos envolvendo distância, somente os falantes menos escolarizados empregaram a copiadora em sintagmas preposicionados, os mais escolarizados a utilizaram exclusivamente em posição de sujeito. Nas palavras da própria autora, "pode-se concluir que essa é uma variável estrutural forte que aponta o "locus sintático" do sujeito como favorecedor dentre as demais funções".

Quanto aos outros fatores sociais, sexo e idade, os dados de fala apontaram uma tendência de os falantes do sexo feminino e de menos idade empregarem mais a estratégia de cópia.

De forma sucinta, os dados examinados pela autora indicam que o fator mais influente ao emprego da estratégia copiadora é a distância, evidenciando que o pronome tem uma função muito explícita e específica, que é facilitar a retomada de referentes. Quando o fator distância está em cena, é notado também influência da função sintática. Os resultados mostraram que à medida que o grau de escolaridade aumenta, a forma cortadora vai sendo preferida em relativas preposicionadas, enquanto que a copiadora é predominante na posição de sujeito. 


\section{3}

\section{Propostas teóricas para a estrutura das orações relativas restritivas}

Dentro do escopo da Teoria Gerativa, diversas propostas de caracterização das orações relativas restritivas vêm sendo apresentadas. Essas diferentes abordagens, no entanto, podem ser resumidas em três linhas de investigação: aquela que considera as orações relativas como adjuntos dentro do sintagma nominal, tal como proposto originalmente em Chomsky (1977), outra que toma essas estruturas como complemento, nos moldes de Kayne (1994) e, ainda, aquela que se apresenta como um meio-termo entre essas duas propostas (SAUERLAND,1998; 2001; SALZMANN, 2006). A seguir, apresentamos resumidamente cada uma dessas análises para as orações relativas.

\section{1}

\section{Head external analysis - Hipótese da adjunção com movimento de operador}

Buscando uma análise unificada para a derivação de relativas, topicalizações, clivadas e comparativas, Chomsky (1977) propõe que todas essas construções são derivadas via regra de Movimento QU-, apresentando as seguintes características:

(i) presença de uma lacuna (vestígio);

(ii) possibilidade de relações de longa distância;

(iii) sensibilidade a restrições de ilhass.

Especialmente para relativas, a proposta é que essas sejam estruturas de $\mathrm{COMP}_{9}$, envolvendo adjunção da relativa ao NP, e movimento do elemento QUpara o sintagma do COMP interno à relativa. Considere, como exemplo, a

$8 \mathrm{~A}$ restrição de movimento do pronome relativo para a posição de [spec $\mathrm{CP}$ ], atravessando uma barreira sintática, justifica-se pelo princípio da subjacência: "No rule may move an element from the position $\mathrm{Y}$ to the position $\mathrm{X}$...X...[ $\alpha \ldots[\beta \ldots \mathrm{Y} \ldots] \ldots \mathrm{X} \ldots$..., where $\alpha$ and $\beta$ are bounding nodes." (CHOMSKY, 1977, p.86).

9 No Modelo adotado em (1977), a regra de reescritura era: S' $\rightarrow$ COMP (complementizador) $\{$ S, S'\}, sendo o complementizador that o núcleo de COMP. 
derivação dada em (7). Em um primeiro passo derivacional (7a), o COMP relativizador adjunge-se ao NP a book. Em seguida (7b), a regra de movimento QU- aplica-se, movendo o item which para COMP. Na sequência which that, um dos itens é apagado, gerando (7c) e (7d):

(7) a. I found [NP a book [Comp that [s you can read which]]]

b. I found [NP a book [Comp which that [s you can read - ]]]

c. I found [NP a book [COMP that [s you can read - ]]]

d. I found [NP a book [Comp which [s you can read - ]]]

Portanto, na proposta de Chomsky (1977), as relativas são estruturas adjuntas ao NP modificado e envolvem movimento QU- para o CP da relativa. Em (7), embora o NP a book seja interpretado como o objeto lógico do verbo read, interno à relativa, ele não é gerado na posição de complemento deste verbo, mas sim na posição superficial em que aparece.

A questão é, portanto, explicar a relação interpretativa entre a expressão nominal relativizada e o verbo da relativa (book e read em (7)). Para Chomsky, essa relação é assegurada por uma regra de ligação (Bound anaphora), que atribui ao pronome relativo o mesmo índice que o NP antecedente, como em (8):

(8) I found [NP a book 1 [Comp which 1 that [s you can read - ]]]

A correferência entre o NP alvo e o elemento QU- é um processo que ocorre em LF, pelo qual a oração relativa atua como predicado adjunto ao NP. A relativa é, portanto, tomada como um sintagma aberto, um predicado, que precisa ser associado a um NP com referência ainda aberta, de modo a permitir uma interpretação anafórica em LF. (CHOMSKY, 1977, p.81)

Refinando essa análise, Safir (1986) busca dar conta da interpretação das relativas a partir de dois tipos de ligação: a ligação X, que é uma instância de ligação A-barra - tal como proposta por Chomsky- e a Ligação - R. Enquanto a ligação X diz respeito à indexação entre o operador QU- movido para posição spec/CP e o seu vestígio, a ligação - R, ou ligação por um antecedente relativo, trata da relação referencial entre a oração relativa e seu antecedente nominal. No exemplo (9), 
retirado de Safir (1986, p.665), o operador who está ligado, via ligação X ao seu vestígio, enquanto que o antecedente $a$ man está R- ligado tanto ao operador quanto ao vestígio.

(9) $\left[\mathrm{NP}[\mathrm{NP} \text { a man }]_{i} \mathrm{~S}\left[\mathrm{Comp}\left[\mathrm{who}_{i}\right]_{\mathrm{s}}\left[\right.\right.\right.$ Bill knows $\left.\left.\left.[\mathrm{e}]_{i}\right]\right]\right]$

Decorre disso, a condição de localidade (Locality Condition on R-Binding - LCR), atuante sobre a Ligação-R, a qual estabelece que:

(10) If $X$ is locally R-bound, then $X$ is the structurally highest element in CP. (SAFIR, 1986, p. 678)

Sendo assim, a relação entre o NP e a relativa é sempre mediada por um antecedente A-barra, isto é, o operador relativo, o que implica que na ligação-R deve haver a co-indexação do operador relativo a um antecedente expresso na oração principal. De acordo com o autor, é nesse sentido que a referência de núcleos restritivos é dependente da oração modificadora, leia-se relativa (SAFIR, 1986, p.668).

No caso das orações resumptivas, conclui-se que os pronomes estão sujeitos a ambos os tipos de ligação, tendo em vista que o pronome resumptivo também se mantém X ligado ao operador em CP, que, por sua vez, está R-ligado ao antecedente da relativa, um processo referencial que não ocorre na sintaxe visível, mas em LF.

Assim como em Chomsky, na proposta de Safir, o NP antecedente atua como uma espécie de predicador coindexado ao operador relativo em LF, em que se garante que ambos os elementos recebam o mesmo índice e sejam devidamente indexados e corretamente interpretados, obedecendo, assim, ao Princípio da Interpretação Plena.

Ambas as propostas não apresentam de forma satisfatória, no entanto, uma explicação para o estabelecimento da correferência entre NP e elemento QU-, na medida em que essas teorias preveem que essa regra de predicação ocorra somente em LF. Kenedy (2002, p. 34) ressalta que essas teorias não são capazes de explicar de que modo ocorre o compartilhamento de traços morfossintáticos entre NP e o elemento QU-, tendo em vista que a checagem desses traços não ocorre antes da Estrutura-Superficial, isto é, antes da divisão da derivação em PF e LF. Além disso, 
parecem considerar que o mecanismo da referência seja livre, sem restrições, como nas condições de ilha, já que, uma vez que ocorre em LF não está sujeito a relações de subjacência.

Com o amadurecimento da teoria gerativa, a partir do Programa Minimalista (PM), a operação de movimento passa a ser justificada como uma necessidade de checagem de traços formais. No que tange ao movimento de QU-, em Inglês por exemplo, o entendimento é que o elemento QU- e pronomes interrogativos têm um traço formal que força o movimento para a posição de especificador de $\mathrm{CP}$.

No modelo proposto por Chomsky (1995), a operação Move é resultado da combinação das operações Merge, Copy, Delete, sendo que Delete corre em PF para garantir a linearização da estrutura, de acordo com a proposta de linearização de Kayne (1994).

Dessa forma, na derivação de uma oração relativa, o elemento QU- move-se para checar traços formais, deixando uma cópia do elemento movido na posição de origem. Essa cópia é apagada em PF, reduzindo, assim, a cadeia formada via movimento. Isto é, os itens de uma cadeia formada por movimento A-barra, que não estão na posição de operador (Spec, $\mathrm{CP}$ ) são, via de regra apagados em $\mathrm{PF}$. É importante ressaltar que nesta perspectiva não é o item lexical em si que engatilha movimento, mas sim os traços formais não interpretáveis de uma categoria funcional. Esses traços formais, ao identificarem em seu domínio de complemento categorias lexicais com traços formais relevantes (i.e., que podem entrar numa relação de checagem/valoração de traços), desencadeiam o processo de Agree e Merge. Nesse processo, em caso de movimento antes de Spell-out, não apenas os traços formais da categoria lexical são copiados e concatenados dentro do domínio de checagem da categoria funcional, mas também os traços semânticos e fonológicos são carregados/piedpiped, junto com os traços formais relevantes.

Uma noção importante dentro do PM é a noção de custo derivacional. Primando pelo Princípio da Economia, o sistema computacional dá preferência a passos derivacionais que envolvam menos operações computacionais, ou seja, operações sintáticas com menos custo derivacional. Dessa forma, dado que Move é uma operação complexa, sendo uma combinação de outras três operações, a preferência do sistema é aplicar Merge sempre que possível, guardando a operação Move para casos em que sua aplicação é condição obrigatória para a convergência 
da estrutura gerada10. Essa preferência nos dá uma das máximas do PM: Merge over Move.

Dado Merge over Move, os três tipos de relativas que estamos pesquisando tornam-se uma questão importante. O tipo que tem mais custo computacional: (a) a estratégia padrão, em que o pronome relativo e o $\mathrm{N}$ relativizado, como veremos abaixo, formam um complexo, que depois é movido para $\mathrm{CP}$, carregando elementos dependentes, como preposições; (b) a estratégia cortadora, em que há apagamento da preposição na posição de origem do elemento relativizado, diminuindo, assim, o número de traços a serem copiados e concatenados na nova posição; ou (c) a estratégia resumptiva, na qual um pronome é inserido na posição de origem, fazendo com que a interpretação da cadeia seja facilitada pela presença do resumptivo?

Para entendermos melhor a relativização e melhor avaliar diferentes estratégias de relativização é preciso entender a estrutura interna das expressões nominais, a fim de compreender como se dá a relação entre a oração relativa e o nome relativizado.

A partir de várias evidências empíricas, Abney (1987) propõe a hipótese DP, pela qual a projeção máxima de uma expressão nominal não seria um NP, mas sim um sintagma determinante (DP), nucleado por uma categoria funcional: um determinante.

À semelhança das sentenças, que apresentam uma categoria funcional TP (tempo) que seleciona, como complemento, o VP, nucleado por uma categoria lexical, o DP seleciona como complemento o NP, também nucleado por uma categoria lexical, formando a seguinte estrutura11:

$$
\begin{array}{lrr} 
& \mathrm{DP} & \\
\mathrm{D} & & \mathrm{NP} \\
& 3 & \\
& \mathrm{~N} &
\end{array}
$$

10 Chomsky (1995, p. 220): "[...] derivation [of a linguistic expression of L] must be optimal, satisfying certain natural economy conditions: locality of movement, no "superfluous steps" in derivations, and so on. Less economical computations are blocked even if they converge".

11 É importante observar que estamos adotando aqui uma simplificação do domínio nominal, colocando de lado o fato de que há entre o $\mathrm{D}$ e $\mathrm{N}$ pelo menos uma outra projeção funcional. 
Evidência a favor da estrutura em (11) é o fato de os determinantes não ocorrerem sozinhos, mas, ao contrário, selecionarem obrigatoriamente um complemento NP. Quando determinantes aparecem sozinhos na sequência linear, sabemos que houve um processo de elisão do NP na estrutura sintática.

Em sentenças como (12), em que há DPs quantificados, a relativa modifica girl e não a expressão nominal no girl, como a forma lógica em (12b) indica, já que o quantificador em (12a) expressa que não há uma menina, tal que você gosta dessa menina e que essa menina veio para a escola hoje. Crucialmente, (12a) não significa que não há uma menina que você gosta. Portanto, a relativa that you like não pode estar modificando o DP todo. Ou seja, se a relativa for um adjunto, não pode estar adjunta ao DP.

(12) a. No girl that you like came to school today.

b. There is no $x$, such that $x$ is a girl and you like $x, x$ came to school today.

Desse modo, uma nova proposta de análise para as relativas faz-se necessária, já que nas propostas pré-Abney, as relativas eram analisadas como modificando o NP, a projeção máxima de uma expressão nominal, na qual o determinante ocupava a posição de especificador.

\section{2}

\section{Raising analysis - Hipótese da complementação com movimento de N}

Kayne (1994) oferece uma proposta de análise das orações relativas que se coloca como um contraponto à análise lançada em Chomsky (1977). Tal modelo considera que essas estruturas são derivadas via alçamento do $\mathrm{N}$ relativizado (ou raising).

Na proposta kayniana, a estrutura sintagmática determina a ordenação linear dos constituintes. De acordo com o Axioma de Correspondência Linear (Linear Correspondence Axiom - LCA - KAYNE, 1994), as relações de precedência na 
ordem linear refletem relações assimétricas de c-comando na estrutura sintática12, de modo que se X c-comanda assimetricamente $\mathrm{Y}$, então $\mathrm{X}$ precede $\mathrm{Y}$ linearmente. Decorre dessa relação de c-comando assimétrico que o LCA é um modelo mais rígido para o processo de ordenação de constituintes. Dita o LCA que a ordem especificador-núcleo-complemento é um princípio estrutural subjacente a todas as línguas, sendo assim, a ordem complemento-núcleo, encontrada em línguas SOV, como o Japonês, por exemplo, é derivada via movimento. Isso implica que a posição à direita do núcleo é reservada a complementos e a adjunção à direita é banida. Em outras palavras, no modelo de Kayne, adjuntos são gerados, sempre à esquerda do núcleo. Desse modo, as orações relativas não podem ser tratadas como adjuntos, tal como na proposta chomskyana13.

Kayne propõe que essas estruturas são CPs que ocupam a posição de complemento do determinante, como em (13):

$$
\text { (13) }\left[\mathrm{DP} \mathrm{D}^{0}[\mathrm{CP} \mathrm{C}]\right]
$$

Além disso, na proposta de Kayne, a lacuna em posição argumental dentro da relativa é gerada da seguinte maneira:

\section{(14) [DP o [CP trabalho2 [DP que $\left.t_{2}\right]_{1}$ [IP eu revisei $\left.\left.\left.t_{1}\right]\right]\right]$}

Portanto, diferentemente do modelo anterior, aqui, o nome alvo da relativização é gerado no interior da sentença relativa. Em (14), é possível observar que o $\mathrm{N}$ relativizado forma primeiramente um constituinte com o pronome relativizador ([que trabalho]), o qual é originalmente inserido na posição de complemento do verbo revisei, sendo depois alçado, no curso da derivação, para $\mathrm{C}^{0}$. Do núcleo do $\mathrm{CP}$, o nome move-se para Spec de $\mathrm{CP}$, deixando encalhado o

$12 \mathrm{C}$-comando: $\alpha$ não domina $\beta$ e $\beta$ não domina $\alpha$ e cada nódulo ramificante que domina $\alpha$ também domina $\beta$. (MIOTO, 2007)

13 "For languages like English, right adjunction has standardly been assumed in the characterization of various constructions. Every one of these constructions must be rethought in a way compatible with the unavailability of right adjunction. The range is substantial: right dislocation, right node raising, relative clause extraposition, heavy NP shift, coordination, multiple complements and multiple adjuncts, possessives like a friend of John's, partitives, and also relative clauses, which must be reanalyzed in the spirit of the rasing/promotion analysis that dates back to the early seventies." (KAYNE, 1994, p. 13-14) 
pronome relativizador. Por essa razão, a proposta de Kayne para a derivação das relativas, ficou conhecida como análise de alçamento.

A estrutura em (15) representa de forma sucinta as diferenças entre as duas propostas derivacionais para as relativas 14 :

(15) a. relativas como adjuntos de NP (CHOMSKY, 1977)

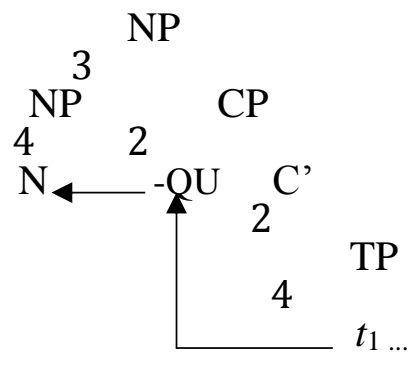

b. relativas como complementos de DP (KAYNE, 1994)

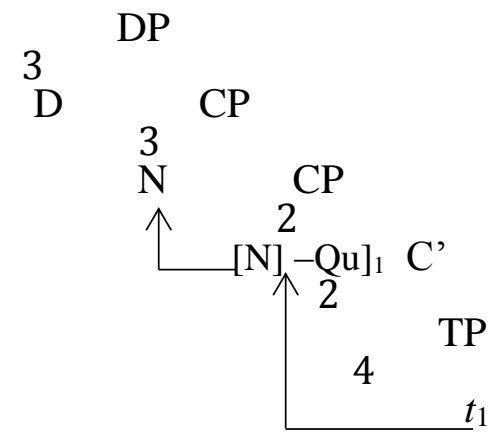

Uma grande vantagem do modelo em (15b) sobre o modelo de adjunção (15a) reside no fato de não ser necessário pressupor a existência de uma regra de predicação pós-sintática, em LF, para o estabelecimento da referência entre relativa e o nome antecedente. Na medida em que o Nome é derivado no interior da relativa, a interpretabilidade da derivação é garantida via computação sintática. Ainda, uma vez que uma oração relativa faz referência a um elemento nominal, delimitando e determinando-o, parece pouco coerente considerar Nome e oração relativa como 
estruturas independentes, tal como previsto no modelo de adjunção, originalmente proposto por Chomsky (1977).

Assim, embora à primeira vista a proposta de alçamento pareça ferir o princípio da economia por envolver um número maior de passos derivacionais dois movimentos sucessivos - o fato de a relação de correferência ser estabelecida em termos sintáticos torna a geração de uma estrutura relativa por complementação mais vantajosa do ponto de vista computacional, embora entendamos que seja difícil definir que tipo de derivação é menos custosa, em termos de passos derivacionais, para o sistema computacional, se aquela proposta por Chomsky, em que há necessidade de aplicação de princípios de ligação em LF, ou aquela proposta por Kayne, em que há dupla aplicação da operação Move. No entanto, é importante ressaltar que, ao se propor uma análise em que a relação de correferência é realizada via computação sintática, dispensa-se operações de binding, que são de difícil testagem.

\section{3}

\section{Matching Analysis - Hipótese da adjunção com dois núcleos idênticos}

Uma outra proposta que tem origem em Chomsky (1965) é a chamada matching analysis, a qual foi aprimorada e refinada ao longo dos anos, tendo seus desenvolvimentos mais recentes com Bhatt (2002), Sauerland (1998) e Salzmann (2006). A análise matching compartilha semelhanças tanto com a proposta de movimento QU- quanto com a de alçamento. Tal qual a proposta de movimento QU-, considera a existência de um núcleo relativo gerado fora da oração relativa e a adjunção da oração relativa ao núcleo nominal. Já com a proposta de alçamento, partilha da ideia de que existe uma representação interna do núcleo relativo.

Nessa proposta, as relativas assumem seguinte configuração (BHATT, 2002, p.5):

(16) The book which John likes. 


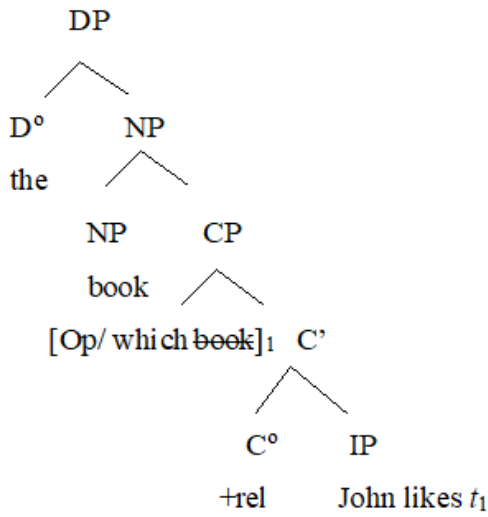

A estrutura em (16) mostra a adjunção da oração relativa (CP) ao NP (book). $\mathrm{O}$ núcleo relativo (book) é gerado na base e, portanto, fora do $\mathrm{CP}$ relativo. Esse núcleo, além de ser interpretado fora da oração relativa, também o é na posição interna (cópia). Esse núcleo interno é complemento do operador relativo, formando um DP (which book) que se move para [Spec, CP], posição na qual, em algumas propostas - Sauerland (1998) e Salzmann (2006) -, o núcleo interno é apagado em PF por identidade (que não precisa ser completa, conforme veremos adiante) com o núcleo externo. Esse apagamento da representação interna faz com que o núcleo externo seja o antecedente da relativa.

Na medida em que núcleo externo e interno não estão ligados por uma cadeia de movimento A', mas sim por um mecanismo de elisão, o núcleo externo (antecedente) pode ser representado por um pronome na elipse, o que permite a ausência dos efeitos do Princípio $\mathrm{C}_{15}$ nas orações relativas:

15 O Princípio C, proposto na Teoria da Ligação de Chomsky (1981) estabelece que as expressões referenciais-R sejam livres, ou seja, não ligadas (c-comandadas) a um elemento que porte o mesmo índice referencial. 
(17)

a. The picture of $\mathrm{John}_{1} \mathrm{he}_{2}$ likes
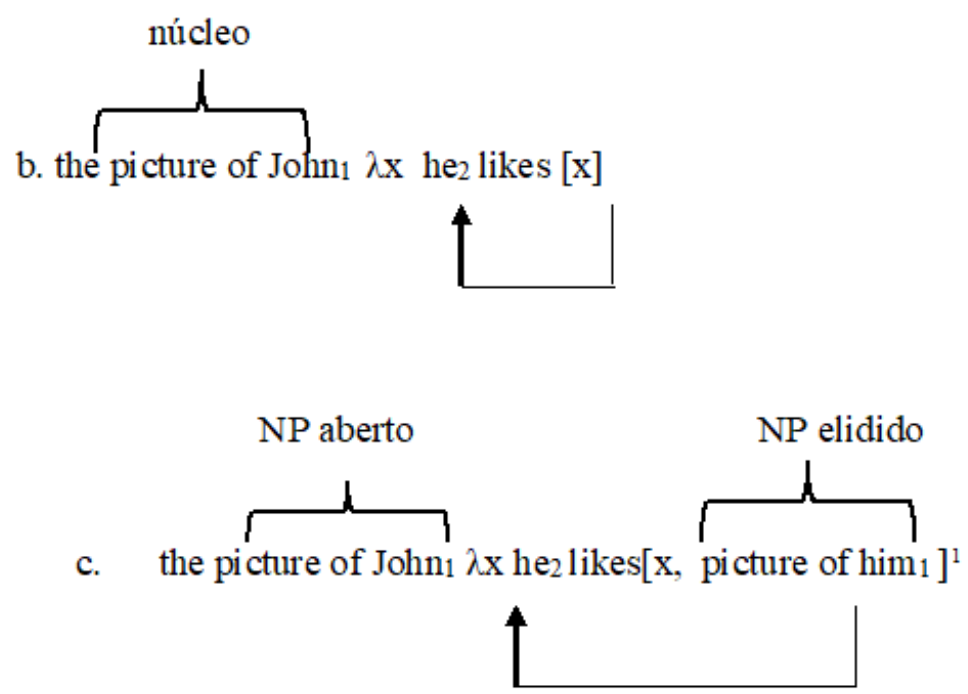

(SAUERLAND, 1998, p.76)

O exemplo (17) mostra que o núcleo externo picture of John está representado, internamente, pelo pronome him. Ambos estão relacionados por elipse e são interpretados em LF. Em PF, porém, o núcleo interno será apagado e o externo tomado como antecedente. A correferência entre os dois núcleos não fere o Princípio de $\mathrm{C}$, na medida em que o núcleo externo, expresso por uma expressão referencial, encontra-se livre, isto é, não possui antecedente que o c-comande 16 .

No entanto, assim como os outros dois modelos apresentados, a análise de matching também apresenta algumas inconsistências. Bhatt (2002) faz alguns apontamentos nessa direção ao questionar o porquê de a regra de elipse - pela qual a representação interna é apagada - ser obrigatória e, ainda, o porquê de o núcleo externo ser o elemento pronunciado e não o núcleo interno. Um terceiro argumento levantado diz respeito às relativizações com expressões idiomáticas. De acordo com a proposta matching, tanto o núcleo externo quanto o interno devem ser interpretados, porém, no caso de expressões idiomáticas, parece que o núcleo é

\footnotetext{
16 Análises que tomam a oração relativa como complementos do núcleo externo, como Kayne (1994), apresentam violação do Princípio C, já que a oração relativa é um complemento e deve ser inserido na posição original para receber papel temático, resultando em uma configuração em que a expressão referencial (antecedente) seja c-comandado pelo pronome: [DP [ D the[CP $\left[\mathrm{DP}_{\mathrm{j}}[\mathrm{NP}\right.$ Picture of $\mathrm{John}_{\mathrm{i}}$ ] [DP which ${ }_{\mathrm{ti}}$ [ C' he likes $\left.\left.\left.\left.\left.\left.t_{\mathrm{j}}\right]\right]\right]\right]\right]\right]$. Já nas propostas que a considera um adjunto, a oração relativa pode ser inserida após o movimento do núcleo interno para Spec $\mathrm{CP}$, deixando-a livre do c-comando do pronome.
} 
interpretado somente internamente. Ilustremos essa questão com um exemplo da expressão "quebrar um galho" formada por verbo + complemento:

(18) a. O galho que eu quebrei me deixou orgulhoso.

O complemento verbal ("galho") é o NP alvo da relativização. Em uma proposta de derivação por matching, temos:

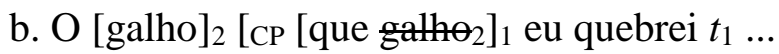

Por se tratar de uma expressão idiomática, deve haver entre "quebrar" e "galho" uma relação sintática de núcleo + complemento, o que pressupõe que devem, ambos, ser gerados no interior da relativa, assim como propõe a análise raising. Ao contrário, pela análise matching representada em (18b), o complemento verbal seria gerado em uma posição externa à relativa, dissociável, portanto, do núcleo verbal, o que não é suficiente para explicar as relativizações de expressões idiomáticas.

Embora apresente evidências a favor de uma análise matching para as relativas, Sauerland (1998;2001), Hulsey e Sauerland (2006) e também Bhatt (2002) consideram a insuficiência de apenas uma proposta de análise para dar conta da derivação de orações relativas. Sauerland ressalta que as relativas do Inglês possuem natureza ambígua, relacionada à posição em que o núcleo da relativa é interpretado. Em alguns casos, esse núcleo externo deve ser interpretado exclusivamente em posição interna, como propõe a análise raising, e em outros, deve ser interpretado interna e externamente, como na proposta matching. Nessa proposta, relativas com estrutura raising se restringem a casos envolvendo expressões idiomáticas, ligação de variáveis 17 - quando anáforas/variáveis no núcleo relativo estão vinculadas a um elemento dentro do $\mathrm{CP}$ relativo $-\mathrm{e}$ de

17 Exemplo de ligação de variáveis envolvendo análise raising é dada por Hulsey e Saurland (2006, p. 113):

a. Mary liked the picture of himself that John sent.

b. Mary liked the kx John sent the $x$ picture of himself $x$ 
escopo18, enquanto que a análise matching seria a estrutura padrão, justificada, principalmente, pela ausência de violação ao princípio C.

\section{4}

\section{Em síntese}

As três propostas de análise para as orações relativas diferem-se, basicamente, em dois pontos, quais sejam, na posição de origem do núcleo relativizado (antecedente) e quanto à relação de adjunção ou complementação das relativas. Todas, no entanto, consideram que a geração dessas estruturas envolve ocupação de posição A-barra.

De todas as propostas apresentadas, somente a chomskyana oferece, de forma mais explícita, um tratamento às relativas formadas com pronomes resumptivos, assumindo que tais estruturas não são derivadas via movimento, mas sim geradas na posição de base. Isso porque, a convergência de pronomes resumptivos não satisfaz a duas restrições a movimento: não são sensíveis a domínios de ilha, e podem ocorrer em posição onde um vestígio poderia ter sido gerado.

Cada uma dessas propostas tem como objetivo dar conta de explicar o fenômeno da relativização, mas, como vimos, todos apresentam virtudes e falhas. Não é foco deste trabalho, no entanto, assumir algum desses modelos teóricos, mas tão somente, oferecer um panorama acerca das principais linhas teóricas que buscam descrever a derivação de uma oração relativa.

\section{5}

\section{Estratégias de relativização no Português Brasileiro}

\subsection{1}

\section{Orações relativas restritivas padrão}

As relativas padrão, que também podem ser referidas como o tipo canônico na gramática tradicional, são caracterizadas por apresentarem uma lacuna (representada aqui pelo símbolo -) no lugar do elemento movido. Este tipo de need for vet school. (need > many)" o núcleo relativo deve ter escopo em posição interna. 
relativa pode ser encabeçada pelos pronomes "que", como em (19 a), "cujo" (19 b) e por um PP (19 c), essas últimas também conhecidas como pied-piping (KENEDY, 2003):

(19) a. A atriz que o fã viu -

b. A atriz cujo cachorro rasgou o livro

c. A atriz com quem o fã conversou -

Além da estratégia padrão, existem duas outras possibilidades de relativização, que veremos a seguir.

\subsection{2}

\section{Orações relativas restritivas não padrão}

São consideras estratégias não-padrão, as cortadoras e as resumptivas, que diferem da padrão pelo fato de apresentarem, respectivamente, apagamento da preposição ou cópia pronominal na posição de extração no interior da relativa.

Uma das grandes indagações teóricas em torno das estratégias não padrão reside em questões sobre suas derivações, se envolvem ou não movimento de constituintes, tal como acontece nas relativas padrão. Não existe na literatura consenso acerca dessa questão. Autores como Tarallo (1983), McCloskey (1990), Shlonsky (1992), Grolla (2000; 2005a), Alexandre (2000) e Lessa-de-Oliveira (2008; 2009b) defendem que a diferença entre as relativas do tipo padrão e as não padrão reside no fato de essas últimas não envolverem movimento do elemento relativizado para uma posição A-barra, sendo o operador QU- gerado na base. Outras propostas consideram, ao contrário, que essas relativas são formadas por movimento (KATO e NUNES, 2009; AOUN, 2000 e HORNSTEIN, 2001; 2007).

Destaca-se, especialmente, a proposta de Kato e Nunes (2009) para o Português do Brasil. Os autores propõem uma análise unificada para os três tipos de relativas no PB, a partir da análise de alçamento (KAYNE, 1994). Nessa proposta, as relativas são formadas a partir da relativização de elementos deslocados à esquerda (Left Dislocation - LD), que podem ser retomados internamente por pronomes lexicais ou nulos (no caso de relativas de objeto direto inseridos em ilhas sintáticas). O elemento "que" é tratado como determinante 
relativo, sendo que a diferença estrutural entre a estratégia padrão e a não padrão é a posição de onde esse determinante é movido. Nas relativas padrão, o "que" sai de uma posição argumental e se move para Spec, CP, apresentando, portanto, efeitos de ilha e de pied-piping (20). Como PPs não podem ser deslocados à esquerda (21), as relativas pied-piping devem ser geradas via movimento e não podem ocorrer com resumptivos (22):

(20) $\left[\mathrm{o}\left[\mathrm{CP}\left[\mathrm{PP} \text { livro } \mathrm{i}\left[\mathrm{PP} \text { de }\left[\mathrm{DP} \mathrm{t}_{\mathrm{i}}\left[\mathrm{DP} \text { que } \mathrm{t}_{\mathrm{i}}\right]\right]\right]\right]_{\mathrm{k}}\left[\mathrm{CP} \mathrm{C}\right.\right.\right.$ [IP você precisa $\left.\left.\left.\left.\mathrm{t}_{\mathrm{k}}\right]\right]\right]\right]$

(21) $\left(^{*} \mathrm{com}\right)$ [aminha amiga]i, você falou com elai por telefone.

$(22) * E s t a$ é [aminha amiga $]_{i}$ com que $/$ /quem $_{i}$ você falou com elai por telefone. (KATO E NUNES, 2014).

Estruturas em que o "que" determinante é gerado na posição do elemento deslocado à esquerda são relativas não padrão, sem efeitos de ilha e sem piedpiping. A configuração de uma relativa resumptiva nessa proposta é a seguinte:

(23) a. Eu tenho [uma [CP [DP amiga $\left[\right.$ DP que $\left.\left.t_{i}\right]\right]_{k}\left[{ }_{C P} C\right.$ [DE $t_{k}[I P$ ela é muito engraçada]]]]]

b. Este é [o [CP [DP livroi $\left[\right.$ DP que $\left.\left._{\mathrm{i}}\right]\right]_{\mathrm{k}}\left[\mathrm{CP} \mathrm{C}\right.$ [DE $\mathrm{t}_{\mathrm{k}}[\mathrm{IP}$ você vai precisar dele $_{\mathrm{k}}$ amanhã]]]]

Percebe-se em (23) que o DP, contendo o pronome relativo e o nome, ligase ao vestígio em posição deslocada à esquerda, o qual é correferente ao pronome resumptivo em IP. Uma vez que a posição de LD é gerada na base e ocorre a coindexação entre o DP deslocado e uma posição no interior da relativa, essa proposta seria bastante econômica, já que o custo computacional está associado à operação de LD e não há necessidade de se pressupor que a ligação entre os elementos correferentes ocorra em um processo pós-sintático. A derivação por LD permite prever a ocorrência de relativas resumptivas sem, necessariamente, associálas a último recurso, tendo em vista que o tipo de elemento anafórico a ser empregado é definido a priori e já inserido no curso da derivação.

Como não é objetivo deste trabalho debater em mais detalhes essas propostas, passaremos à caracterização de cada uma dessas estratégias não canônicas. 


\subsubsection{1}

\section{As orações relativas cortadoras}

As relativas cortadoras, ou $P P$-chopping são passíveis de ocorrer nas posições sintáticas em que o nome relativizado aparece em posição sintática preposicionada, como objeto indireto e oblíquo19, com o apagamento da preposição20, e também na de genitivo, caracterizada pela omissão do possuidor (cf. (23)).

Conforme visto no capítulo 2, essa estratégia é a mais recente no PB, tendo surgido, segundo Tarallo (1983) e Lessa-de-Oliveira (2009 a), na segunda metade do século XIX, como alternativa à padrão e à resumptiva.

A ocorrência da relativa cortadora está associada à impossibilidade da existência de preposição-órfã ( $P$-stranding) na língua portuguesa, tanto em sua vertente europeia, quanto brasileira21. Assim, nessas línguas, uma sentença como (21 a) é agramatical, pois a preposição aparece desgarrada do pronome relativo que se movimentou. Ao contrário, o exemplo (21 b) ilustra uma relativa cortadora, cuja convergência é garantida pelo apagamento de todo o PP:

(21) a. *A menina ${ }_{1}$ que eu conversei com $\mathrm{t}_{1}$

b. A menina $a_{1}$ que eu conversei com $\mathrm{t}_{1}$

Em Inglês, por outro lado, a possibilidade de uma preposição-órfã torna agramatical a estratégia cortadora:

(22) a. The boy I talked to.

b. *The boy I talked.

\footnotetext{
19 Alexandre (2000, p. 64) distingue as posições de objeto indireto e de oblíquo dizendo que o pronome resumptivo em posição de OI apresenta marcas de caso Dativo. Quando aplicado sobe a posição de oblíquo, aparece antecedido por uma preposição selecionada pelo verbo da oração relativa.

20 Para exemplos retomar a subseção 3.3.1.

21 Kenedy $(2008$, p.94) observa que preposições lexicais podem aparecer órfãs em determinadas estruturas sintáticas, como ocorre em: "O autor que o professor falou sobre na última aula" e "É uma uma coisa que eu não consigo ficar sem". Segundo o autor, em alguns contextos específicos, as preposições "sobre" e "sem" podem aparecer órfãs. Já "com" e "de" não permitem esse tipo de construção.
} 
Nas genitivas, a estratégia cortadora22 realiza-se por meio do pronome "que":

(23) A tenista que o treinador _ pediu demissão não vai disputar o próximo campeonato.

No capítulo 5, voltaremos às relativas de genitivo.

\subsubsection{2}

\section{As orações relativas resumptivas}

Ao contrário das relativas padrão, em que o movimento do elemento -QU para a posição de especificador do $\mathrm{CP}$ da relativa gera na posição de origem uma lacuna, e das cortadoras, em que o apagamento do PP também gera lacuna, nas resumptivas, a posição de cauda da cadeia formada entre posição de base e posição de interpretação do elemento movido é preenchida por um pronome correferente ao antecedente (cf. Capítulo 1), sendo, por isso, referido como pronome-cópia. Dessa forma, este pronome apresenta marcas morfofonológicas de traços- $\varphi$ (i.e., pessoa, número e gênero) iguais às do nome antecedente. A estratégia resumptiva parece ser licenciada, no Português do Brasil, em todas as posições sintáticas:

(24) a. Sujeito: Eu conheço uma menina que ela derrubou o copo...

b. Objeto Direto: Eu conheço uma menina que o irmão derrubou ela no chão...

c. Pied-piping: Eu conheço uma menina que o irmão derrubou o copo com $\underline{\text { ela }} \ldots$

d. Genitivo: Eu conheço uma menina que o irmão dela derrubou o copo...

Os pronomes resumptivos não parecem estar sujeitos às mesmas restrições impostas às estruturas derivadas por movimento. Não se aplicam a eles, por exemplo, a condição de subjacência 23 e a restrição de localidade, o que implica que

\footnotetext{
22 A proposta que apresentamos aqui está de acordo com a descrição feita por Alexandre (2000) para o Português Europeu. Diverge, portanto, da análise de Kenedy (2007) no PB, para quem as relativas cortadoras e resumptivas só se aplicam às relativas preposicionadas.

23 Em uma cadeia formada por movimento, a ligação entre vestígio e antecedente não deve conter mais do que uma barreira.
} 
o pronome resumptivo pode estar inserido em uma ilha sintática e estabelecer relações de longa distância com seu antecedente. Mais do que isso, tornam-se imprescindíveis à convergência de derivações quando o movimento é bloqueado:

(25) a.*Those songs we don't know who composed (MCCLOSKEY, 1990)

'Aquelas músicas que nós não sabemos quem compôs __'.

b. Those songs we don't know who composed them. (MCCLOSKEY, 1990)

‘Aquelas músicas que nós não sabemos quem compôs elas'.

Alexandre (2000) defende que os pronomes resumptivos são redundantes por redobrarem o conteúdo semântico do antecedente, o que os tornam último recurso para formar uma derivação bem-sucedida em contextos de ilha24.

Algumas línguas parecem ser mais restritas ao uso de resumptivos do que outras, aceitando-os somente em contextos em que a derivação sem a presença do pronome não poderia convergir. É o caso do Inglês, por exemplo, em que os resumptivos parecem ser estruturas agramaticais, sendo licenciados somente quando há uma restrição gramatical que impede o movimento de constituintes, como uma barreira sintática (26). Vários estudos experimentais apresentam resultados nessa direção, conforme será apresentado no capítulo 4, embora mostrem que, em contextos de maior complexidade, a ocorrência de resumptivos aumente (HOFMEISTER e NORCLIFFE, 2013; ALEXPOUOLOU e KELLER, 2007; ARIEL, 1999).

Línguas como o Português, europeu e brasileiro, ao contrário, são menos rígidas em relação à ocorrência desse pronome, já que o mesmo não está restrito somente a contextos envolvendo ilhas sintáticas. Ainda que sejam estruturas menos aceitas e frequentes que as outras alternativas de relativização em determinados contextos, nessas línguas, as sentenças com resumptivos são menos marginais se comparadas ao Inglês.

\footnotetext{
24 Por outro lado, em termos de processamento, em determinadas condições, como quando o antecedente está distante de sua posição de origem, a presença do pronome resumptivo pode favorecer a recuperação de um nome anteriormente expresso.
} 
Em casos extremos, como o Hebraico, o resumptivo parece ser de ocorrência bem mais livre. A esse respeito, Shlonsky (1992) mostra que em Hebraico, os resumptivos parecem estar em livre alternância com as lacunas nas posições de objeto direto (26a) e sujeito encaixado (26b), são obrigatórios em posição de oblíquo (26c) e de NP interno (genitivo) (26d) e agramaticais em posição de sujeito mais alto (26e):

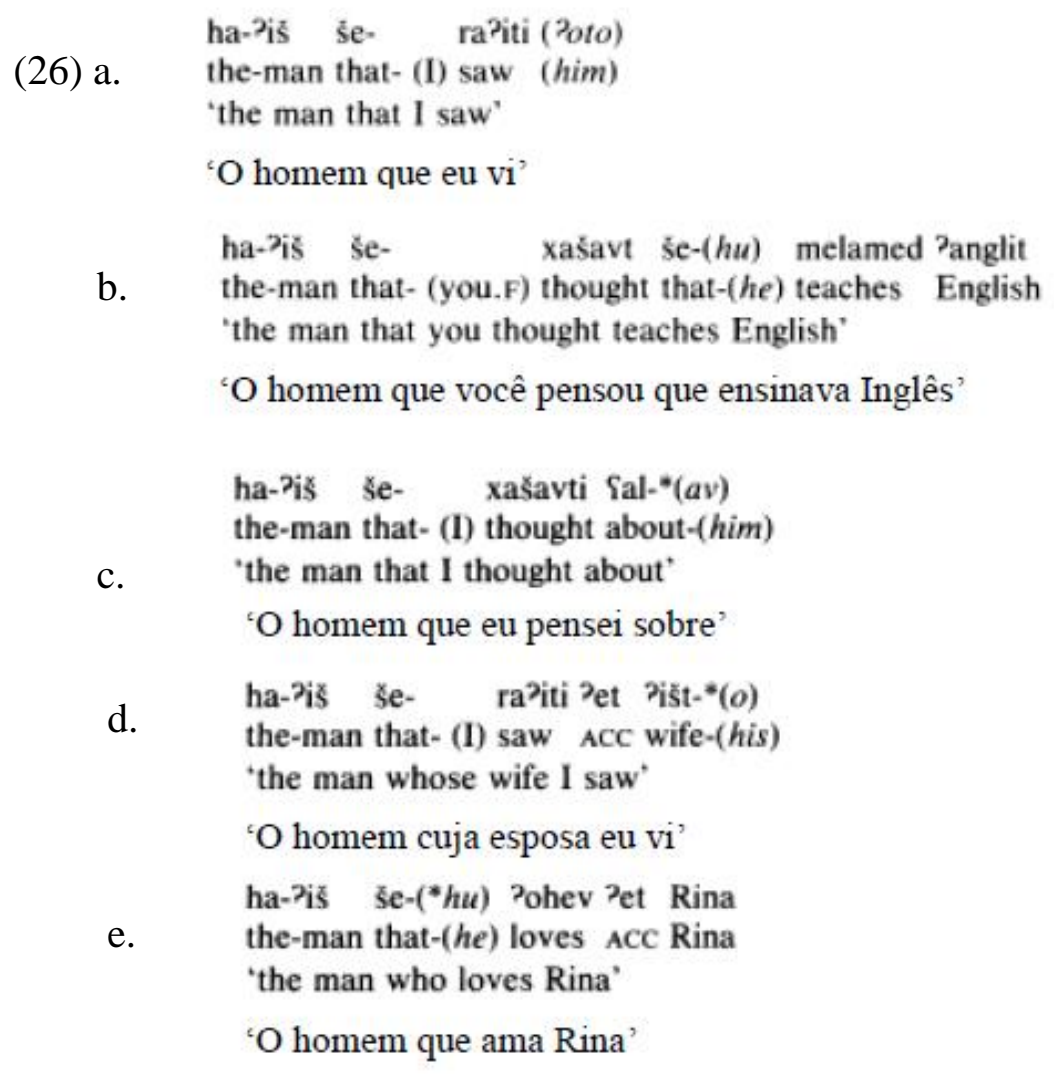

(SHLONSKY, 1992, p.445)

Essa diferença de comportamento dos pronomes resumptivos nas diferentes línguas faz-nos supor que o licenciamento desses elementos resulta de escolhas paramétricas. A partir dessa constatação, Sells (1984) distingue dois tipos de resumptivos: aqueles que se constituem como uma opção gramatical na língua, sendo por isso denominado de resumptivos verdadeiros (true resumptives) e aqueles que não são licenciados pela gramática, os intrusivos (intrusive resumptives). Esse último tipo ocorre como último recurso em línguas como Inglês, em que o pronome só é licenciado quando o movimento é bloqueado (restrições de ilhas sintática, por exemplo). 
Apesar da vasta literatura sobre o tema, algumas questões sobre o status e papel do resumptivo nas gramáticas das línguas e sua incorporação na derivação ainda permanecem em aberto. Na próxima seção apresentaremos algumas propostas que buscam caracterizar os pronomes resumptivos.

\subsubsection{3}

\section{O status do pronome resumptivo}

Hornstein (2001;2007), analisando relações de ligação (Princípio A e B), propõe que estruturas derivadas por movimento são mais econômicas do que aquelas que utilizam pronome-cópia, sendo este artefato empregado ante a impossibilidade de aplicar somente a operação Move. Pronomes resumptivos, são, pois, estratégias de último recurso.

Para o autor, esses elementos não estão presentes na numeração e são inseridos somente quando necessários para a convergência da derivação. Portanto, derivações em que pronome resumptivo é inserido quando a operação Move não incorre em nenhum tipo de violação são consideradas mais onerosas para o sistema computacional, ou seja menos econômicas, quando comparadas aquelas em apenas Move foi aplicado. Ou seja, a geração e inserção de resumptivos na derivação durante o curso derivacional tem um custo para o sistema, sendo, portanto, possível apenas diante da impossibilidade de Move. Portanto, os pronomes são usados em situações específicas, (i) para "salvar" a derivação em contexto de ilha; (ii) para fazer ligação quando movimento não se fizer suficiente; (iii) como elementos expletivos para permitir a convergência quando não houver nada mais na numeração25; e para que a derivação sem pied-piping possa convergir, em língua que não permite encalhamento de preposição, como o PB. Do contrário, a estrutura com movimento é a utilizada.

A proposta de Hornstein para os pronomes resumptivos ajusta-se a línguas como Inglês, em que o uso desses pronomes parece estar limitado a situações de último recurso, quando "salvam" a derivação. No entanto, não é capaz de explicar

25 Exemplos das situações descritas em (ii) e (iii):

(ii) Who did you tell me that he was kissing a dog.

(iii) It seems that John was told that Mary left. 
quando e como os resumptivos são incorporados na derivação, já que não parecem fazer parte da gramática do inglês.

Shlonsky (1992) defende que, mesmo no Hebraico, a ocorrência de resumptivos está atrelada a último recurso. A opcionalidade entre resumptivo e lacuna nos exemplos (26 a e b) é apenas aparente. Para o autor, existem no Hebraico dois complementizadores morfofonologicamente idênticos que podem ocupar uma posição A ou A-barra. Se A é escolhido, o movimento é bloqueado e o resumptivo é obrigatório - exceto na posição de sujeito mais alto. Se, por outro lado, A' é selecionado, o movimento é permitido e a lacuna irá ocorrer. A escolha por um ou outro é, de acordo com o autor, livre e a opção pelo pronome resumptivo no Hebraico é uma ilusão criada pela ausência de traços morfológicos discretos para os dois complementizadores (SHLONSKY, 1992, p. 453).

Visão semelhante é adotada por Grolla (2004; 2005a), que analisa a distribuição de pronomes resumptivos em diferentes posições sintáticas no Português, assim como no Hebraico, demonstrando que, também no PB, esse recurso é empregado para salvar derivações que sem ele não convergiriam, ou seja como estratégia de último recurso.

A autora analisa resumptivos inseridos em quatro posições sintáticas: sujeito, objeto direto, oblíquo e o que ela denomina de NP interno, mas que corresponde à função de genitivo. Em (27) temos exemplos apresentados pela autora para cada posição:

(27) a. O homem que (*ele) ama Maria

(SUJEITO)

b. O homem que eu vi a mulher $(\mathrm{d}-*(\mathrm{ele}))$

(NP interno/GENITIVO)

c. O homem que eu conversei (com*(ele))

(OBLÍQUO)

d. O homem que eu vi (ele)

(OBJETO DIRETO)

A impossibilidade de ocorrência de resumptivos na posição de sujeito sem que haja uma ilha sintática, como em (27a) é explicada por princípios de economia. Uma vez que o movimento curto da posição de [spec, TP] para [spec, CP] é permitido, o pronome não é necessário. Ainda, a inibição da ocorrência de resumptivo nesse contexto é explicada por McCloskey (2007) a partir da condição de restrição do sujeito mais alto. Tal restrição estipula que o pronome não pode 
ocupar uma posição de sujeito que esteja imediatamente subjacente ao elemento ao qual está ligado, por uma violação do Princípio B26.

Nota-se, no entanto, que, embora a derivação com pronome resumptivo na posição de sujeito em (27a) seja considerada agramatical por Grolla, ela é possível em PB, conforme mostram os dados experimentais e de corpora (TARALLO, 1988; LESSA-DE-OLIVEIRA, 2009; MIRANDA, 2005). Além disso, a possibilidade de ocorrência de um resumptivo na posição de sujeito pode ser maior se houver distância linear entre pronome resumptivo e antecedente e também se o antecedente apresentar o traço [+indefinido]. (MOLLICA, 2003)27.

No caso das posições de oblíquo e de genitivo a obrigatoriedade do resumptivo é explicada pelo Princípio da Categoria Vazia (ECP - Empty Category Principle)28. Em Português, semelhantemente ao que ocorre em Hebraico, não ocorreria o fenômeno de preposição-orfã. A gramaticalidade desses tipos de estruturas pode ser garantida, então, por meio de dois recursos: pelo pronome resumptivo, resultando em uma sentença como: "o homem que eu conversei com ele" e "o homem que eu vi a mulher dele" 29 , ou o apagamento de todo o sintagma preposicional e sua substituição por uma lacuna (“O homem que eu conversei”; "o homem que eu vi a mulher"), que resultaria em uma estratégia cortadora.

No caso das relativas de objeto direto, a aparente alternância entre lacuna e pronome resumptivo impõe um problema à hipótese de último recurso. No entanto, a autora busca resolver esse impasse justificando que a legitimidade de ambas as formas (lacuna e pronome) é possível pois, nesse caso, a lacuna não corresponde a um vestígio oriundo de movimento, mas, na verdade, a um pronome resumptivo nulo. A hipótese é sustentada por Grolla (2005b) pela possibilidade de a lacuna ocorrer dentro de ilhas, o que evidencia a ausência de movimento e, portanto, a tese de que se trata de um pronome resumptivo nulo (pro):

(28) a. Esse é o livro 1 que o João conhece [ a autora que escreveu ele 1 ]

\footnotetext{
${ }_{26}$ O Princípio B, na Teoria de Regência e Ligação estabelece que a relação entre um pronome e seu antecedente não pode ocorrer dentro do mesmo domínio de ligação (CHOMSKY, 1981). 27 Um exemplo desse tipo de estrutura seria: Minha mãe conhecia o homem que todo dia de manhã bem cedinho ele entregava o jornal.

28 Trata-se de uma princípio universal que legitima os vestígios, determinando que esses sejam regidos apropriamente

29 Exemplos retirados de Grolla (2005, p.75).
} 
b. Esse é o livro1 que o João conhece [ a autora que escreveu _ 2 ] (GROLLA, 2005b, p.172)

Assim, para a autora, a hipótese de último recurso não é inviabilizada no caso das relativas de objeto direto, visto que a aparente variação entre lacunas e pronomes é na realidade uma variação entre pronome nulo e pronome resumptivo e não entre movimento/inserção de pronome. Entretanto, Kato e Nunes (2009) trazem à discussão o fato de que somente em configurações de ilhas é possível a existência de um pronome nulo em posição de objeto direto. Fora desse contexto, a derivação de uma relativa de objeto direto está associada a operação de movimento. De acordo com os autores, se correta, essa proposta está de acordo com a proposta de Hornstein (2001; 2007), pela qual a operação de movimento é favorecida em relação à resumpção se ambas opções levarem à convergência de derivação.

Diante do exposto, assumimos para o $\mathrm{PB}$ que os pronomes resumptivos são recursos disponíveis e aplicados somente como último recurso, dado seu alto custo. Entende-se o conceito de último recurso aqui de forma não tão restrita como no Inglês, tendo em vista que em Português do Brasil os resumptivos parecem ocorrer também em contextos de não-ilha. Portanto, são empregados não somente quando há uma restrição gramatical (efeito de ilha, preposição-órfã, etc.), mas também para suprir demandas impostas por condições de interface.

\section{6. \\ Custos associados à derivação de relativas: uma possível análise para as estratégias de relativização do PB}

$\mathrm{Na}$ seção anterior, descrevemos aspectos estruturais e derivacionais envolvidos na construção de orações relativas, discutiremos agora os possíveis custos envolvidos na geração dessas orações, com foco nas três estratégias de relativização do PB. É importante distinguir diferentes tipos de custo relacionados às relativas: o custo derivacional, atrelado às operações computacionais consideradas no momento de geração da estrutura e o custo pós-sintático relacionado a condições impostas pelas interfaces lógica e fônica.

Retomando o que já foi dito anteriormente, a computação linguística deve zelar pelo Princípio da Economia, o que significa que deve favorecer derivações 
e, consequentemente, representações menos complexas. Se entendermos que estruturas complexas têm maior custo derivacional, e que esse custo pode ser medido tanto durante a derivação (e.g. merge over move), como nas representações nas interfaces (REINHART, 2004), então segue-se que operações envolvendo movimento, como as que envolvem a derivação de relativas, são por si só custosas (CHOMSKY, 1995)30. No entanto, observa-se também uma possível assimetria de custo no que tange aos diferentes tipos de estratégias de relativização. Essa assimetria é provocada por diferentes fatores que devem ser considerados nas interfaces. No restante da seção, concentraremos-nos na apresentação desses fatores.

O efeito de intervenção é, comumente, considerado como fator de custo na compreensão de relativas. Grillo (2009) argumenta em favor desse fator a partir da proposta de minimalidade relativizada de Rizzi (2004), a qual prevê que as relações sintáticas devam ser satisfeitas no domínio estrutural mais local. Essa relação em uma configuração do tipo $[\mathrm{X} Z \mathrm{Y}]$ deve ser estabelecida entre $\mathrm{X}$ e Y se $\mathrm{Z}$ não intervir entre $\mathrm{X}$ e $\mathrm{Y}$ e não for do mesmo tipo estrutural que $\mathrm{X}$. $\mathrm{O}$ efeito de intervenção nesse caso só ocorre, portanto, se o elemento $\mathrm{Z}$ apresentar as mesmas características morfossintáticas que $\mathrm{X}$, definidas em termos da classe estrutural a qual pertence (por exemplo, argumental, quantificacional, de modificador, etc.). A atuação desse efeito permite explicar, por exemplo, o porquê de relativas de objeto direto serem mais difíceis de serem compreendidas do que as de sujeito.

Friedmann, Belletti e Rizzi (2009) propõem uma extensão da noção miminalidade relativizada (RIZZI, 1990) para explicar dificuldades na produção e compreensão de relativas de objeto. Para os autores, em uma configuração do tipo [X Y Z], uma dependência A-barra entre X e Z apresentará um efeito de intervenção se Y é um candidato a participar da dependência. Em casos de relativas de objeto, o sujeito intervém na relação A-barra entre o antecedente (o pronome QU- (ou o DP [Pronome + nome] na análise de Kayne) na posição de especificador de CP) e a posição lacunada na posição de objeto. Em (29), por exemplo, a dependência formada pela lacuna e seu antecedente é dificultada pelo efeito da intervenção do DP “o professor”.

30 Independentemente da proposta de análise teórica assumida, conforme visto, todas elas envolvem, de alguma forma, a operação de movimento. 
(29) A aluna que o professor elogiou _ ganhou uma bolsa de estudo.

Em contraste, relativas de sujeitos (30) não envolvem efeito de intervenção, pois não há um DP interventor entre o antecedente e a posição lacunada.

(30) A aluna que _ elogiou o professor ganhou uma bolsa de estudo.

Em relação às genitivas, temos a seguinte estrutura em (31):

(31) $\left[\mathrm{DP}\right.$ a ... [NP aluna [CP cujo [C $\mathrm{C}^{\prime}\left[\mathrm{TP}[\mathrm{DP} \text { pai [PossP }]_{1}\right]\left[\mathrm{T}^{\prime}\right.$ elogiou $2\left[\mathrm{VP} t_{1} t_{2}[\mathrm{DP}\right.$ o presidente...

Nessas, o movimento para [Spec, CP], deve cruzar o DP sujeito que contém o elemento em movimento, criando assim efeito de ilha (left branch), tornando sua derivação complexa e, portanto, impondo maior custo à representação31 nas interfaces.

No tocante às relativas de pied-piping, que são encabeçadas por um PP (32), seu custo é potencializado pelo fato de o movimento envolver um maior número de traços, que são copiados e concatenados em [Spec, CP] (Pied-piping do PP) (ALEXANDRE, 2000). No caso de apenas o elemento contendo o traço QUmover, ocorre preposição encalhada ( $P$-stranding), que não é licenciado em PB.

(32) A escritora [ст [рP de quem] [C' [тр eu gosto __] ] ganhou um prêmio.

Alinhado com a proposta de Alexandre (2000), Kenedy (2007; 2008; 2010), a partir do princípio de economia derivacional do Programa Minimalista, defende a hipótese da anti-naturalidade de pied-piping (APP) em relativas, segundo a qual essas estruturas, por violarem o princípio da economia, não fariam parte da competência linguística dos indivíduos, sendo, pois, fruto de aprendizagem formal e da cultura escrita. Para o autor, a geração de uma relativa preposicionada padrão viola o princípio de economia Mova F, que estabelece que o movimento deve

$31 \mathrm{O}$ termo representação, tal como empregado na teoria gerativa, relaciona-se à codificação da estrutura gerada nas interfaces fônica e lógica. 
conter o menor número possível de traços, devido ao fato de envolver o movimento do DP que contém o traço QU- e também do PP. A hipótese do autor é sustentada por dados de experimentos de julgamento de gramaticalidade e de leitura automonitorada desenvolvidos com adultos brasileiros e portugueses, que demonstraram dificuldade e estranhamento com as orações relativas padrões envolvendo movimento de sintagmas preposicionados32. Ainda, Corrêa (1998), ao analisar a ocorrência de relativas preposicionadas em textos de alunos do Ensino Médio, observou que a utilização de estruturas de relativas preposicionadas ocorre por meio da aprendizagem, em ambiente escolar, o que justifica a sua rejeição e consequentemente substituição por outras construções sintáticas menos custosas, como as cortadoras e resumptivas.

De todo modo, tendo em vista os custos atrelados à derivação de relativas padrão, é possível supor que estratégias de relativização não padrão (resumptivas ou cortadoras) sejam favorecidas em contextos com mais custo. Na proposta de Reinhart $(1999 ;$ 2004)33, a manifestação de uma ou outra estratégia de relativização ocorre por meio da competição e comparação de um conjunto de derivações possíveis. A ideia subjacente é que, dado um conjunto de derivações possíveis, as necessidades de interface determinarão qual será a estrutura convergente, isto é, a mais econômica.

Vamos pressupor que tanto a estratégia cortadora quanto a estratégia resumptiva sejam estratégias de último recurso. Isto é, são usadas apenas quando a derivação apresenta algum tipo de violação na interface. A estratégia cortadora aplica-se em PF e é usada para evitar efeito de P-stranding. Como esta estratégia aplica-se apenas em PF, e não no curso derivacional, duas observações são necessárias: (a) são de uso específico de uma gramática (PB, no caso) e (b) seu custo é menor, já que tem impacto apenas em uma das interfaces (PF). A estratégia resumptiva é um pouco mais complexa-A inserção de um pronome

32 No capítulo 4 serão detalhados os resultados do experimento conduzido.

33 Reinhart apresenta a hipótese de computação a partir de um conjunto de referência. Nas palavras da autora, "the reference set consists of pairs $<\mathrm{d}, \mathrm{i}>$ of derivation and interpretation, and it is motivated by interface needs: A given $\langle\mathrm{d}, \mathrm{i}\rangle$ pair is blocked if the same interface effect could be obtained more economically (i.e., there is a more economical $<$ d,i $>$ competitor in the reference set) (REINHART, 2004, p. 117)". Nessa proposta, defende-se que quando há mais de uma derivação possível, ocorre uma competição e a mais econômica gera sobrecarga na memória irá convergir. Defende-se que essa competição gera um custo de memória, já que se deve manter mais de uma estrutura na memória ao mesmo tempo. 
pleno implica em inserção de traços semânticos e fonológicos e, por isso, têm consequências para as interfaces de PF e LF. Sendo assim, pronomes plenos têm também maior custo que a estratégia cortadora, que ocorre apenas em PF.

$\mathrm{Na}$ derivação de relativas de sujeito, em que o movimento A-barra não incorre em nenhum tipo de violação nas interfaces, não havendo efeito de intervenção, ilha ou P-stranding, consideramos que não ocorre nenhuma estratégia de último recurso. Se ocorrer, aumenta-se o custo computacional, e a representação é descartada, de acordo com o processo de competição entre representações nas interfaces, proposto por Reinhart (2000).

Nas relativas preposicionadas, dado a anti-naturalidade do pied-piping, apenas o elemento QU- é movido, encalhando a preposição. Em PF, dado a violação de P-stranding, o PP, contendo a preposição, é apagado. Observe, que neste tipo de relativa, a estratégia resumptiva é uma possibilidade. No entanto, a inserção de um pronome pleno tem maior custo, e a inserção de um pronome nulo não resolve a violação de P-stranding. Assim sendo, para este tipo de relativa, a melhor solução é a cortadora.

As relativas de objeto são as mais complexas. Neste tipo de relativa, ocorre, como observamos anteriormente, efeito de intervenção, o que dificulta a recuperação do antecedente da lacuna. A estratégia cortadora, que ocorre em PF, não soluciona o efeito observado, já que o mesmo é em LF e não envolve preposição. Dado que o PB é um língua de objeto nulo (CYRINO, 1994), há as seguintes possibilidades para essas relativas: (a) não aplicação da estratégia resumptiva, o que incorre em maior dificuldade no processo de interpretabilidade da sentença; (b), inserção de pronome pleno, o que incorre em maior custo computacional. Portanto, relativas de objeto apresentam maior complexidade derivacional, o que explica o fato de este tipo de relativa ser evitado. Em tarefas de produção eliciada conduzidas com falantes de PB, foi verificado que, crianças e adultos usam, no lugar das relativas de objeto outras estruturas, em que não há presença de um elemento interventor (GROLLA e AUGUSTO, 2016; CORRÊA et al., 2018). Em tarefas de compreensão, essas relativas também se mostam difíceis de serem processadas, conforme veremos com mais detlhes no próximo capítulo. 


\section{4}

\section{Processamento das orações relativas}

O processamento de orações relativas é um dos tópicos de pesquisa mais investigados no âmbito da Psicolinguística, com trabalhos que remontam à década de 60, período em que a Psicolinguística manteve um diálogo bastante estreito com os trabalhos desenvolvidos pela Teoria Linguística de orientação Gerativista (CHOMSKY e MILLER, 1963; CHOMSKY, 1965; MILLER e ISARD, 1964; YNGVE, 1960). Conforme apontam Corrêa et al. (2012, p. 175), o interesse original no tópico está associado às discussões relativas à recursividade e produtividade linguísticas e a questões concernentes aos limites impostos pela memória humana no processamento, pontos que estão no cerne da distinção entre competência e desempenho linguísticos.

As pesquisas sobre relativas têm buscado examinar, sob a ótica do processamento, os fatores que poderiam explicar os custos associado à produção e compreensão de tais estruturas, com destaque para os trabalhos que exploram diferenças de custo derivadas da posição de encaixe da relativa e a assimetria no processamento entre orações relativas de sujeito e de objeto.

No que tange especificamente a estudos sobre resumptivos, as pesquisas em geral partem da proposta, formulada no âmbito da Teoria Linguística, de que os resumptivos são estratégias de último recurso, usados para salvar derivações sintáticas (ver capítulo 3). Assim, as pesquisas em Psicolinguística buscam avaliar as condições que podem favorecer o emprego de orações relativas com resumptivos na produção, e questões de acessibilidade e retomada de antecedentes por elementos resumptivos (vs. vestígios/ cópias não pronunciadas) na compreensão.

Neste capítulo, em que buscamos fazer uma revisão dessa ampla literatura, focamos, na primeira seção (4.1), no processamento das orações relativas, apresentando fatores que podem tornar a compreensão/ produção dessas estruturas mais ou menos custosa. Já em 4.1.2 reportamos resultados de trabalhos experimentais que tratam especificamente dos pronomes resumptivos, discutindo o papel que esses exercem na compreensão (4.1.2.1) e na produção (4.1.2.2). 


\section{1}

\section{Custos associados às orações relativas}

Orações relativas são estruturas que impõem desafios ao processador linguístico no momento de sua produção e/ou compreensão. São orações estruturalmente complexas (cf. capítulo 3), que envolvem relações de longa distância, e, consequentemente, demandam recursos de memória de trabalho.

O custo associado ao processamento dessas estruturas tem sido atribuído a um conjunto de fatores, entre os quais a posição de encaixe da relativa (GIBSON, 2005), a distância entre o elemento relativizado e a lacuna (GIBSON, 1998; 2000; 2005; HOFMEISTER e NORCLIFFE, 2013), a presença e a natureza de elementos intervenientes (WARREN e GIBSON, 1999), função sintática do NP relativizado sujeito ou objeto - (WANNER e MARATSOS, 1978; HOLMES e O'REGAN, 1981; FRAZIER, 1989; GIBSON, 2005; GOUVÊA, 2005; COSTA et al., 2011; KWON et al., 2013) e fatores semânticos, como a animacidade do elemento relativizado (MAK et al., 2002; CABRAL et al., 2015).

Os pesquisadores da área têm focalizado especialmente as demandas de processamento associadas à posição de encaixe da relativa e à distinção entre relativas de sujeito e de objeto. $\mathrm{O}$ trabalho de Wanner e Maratsos, ainda na década de 70 (1978), já aponta para a maior facilidade de processamento de relativas de sujeito em comparação às de objeto direto. Outro estudo, Holmes e O'Regan (1981), também apresentou evidências, por meio da técnica de fixação do olhar, em favor de uma assimetria no processamento de relativas de sujeito e objeto direto, com essas apresentando mais regressões do que aquelas.

No que tange ao tipo de encaixe, diversos trabalhos, no âmbito da teoria linguística (CHOMSKY, 1965; CHOMSKY e MILLER, 1963; MILLER e ISARD, 1964) consideram as relativas centrais como sendo estruturas mais complexas que as finais por demandarem mais recursos de memória de curto prazo34. Ainda, diversos estudos experimentais apresentam evidências de que quanto maior o número de encaixamentos, maior é a dificuldade de processamento (BLAUBERGS

\footnotetext{
34 "Consequently, we would expect that nested constructions should become difficult to understand $[\ldots]$, since available memory $[\ldots]$ is clearly quite limited for real-time analytic operations $[\ldots]$ ". (CHOMSKY e MILLER, 1963, p. 471).
} 
e BRAINE,1974; FOSS e LYNCH, 1969; HAKES e CAIRNS, 1970 apud GIBSON et al., 2005; MILLER e ISARD, 1964; STOLZ, 1967).

No curso do processamento, o processador linguístico necessita armazenar na memória de trabalho as dependências sintáticas incompletas que vão sendo analisadas até que o parsing seja concluído. Nas relativas centrais, a relativa interrompe a oração na qual está encaixada, fazendo com que mais informação seja mantida na estrutura de memória. Ao contrário, nas finais, o processamento da oração principal está em fronteira oracional, refletindo em menos sobrecarga de memória e, portanto, mais facilidade de processamento.

A diferença na complexidade dos dois tipos de encaixe é ilustrada por Gibson (2005) a partir dos seguintes exemplos, que apresentam duas orações relativas encaixadas, sendo (a) de encaixe central e (b) final:

(33) a. The student who the professor who the scientist collaborated with advised copied the article.

'O aluno que o professor que o cientista colaborou com aconselhou copiou o artigo'.

b. The scientist collaborated with the professor who advised the student who copied the article.

'O cientista colaborou com o professor que aconselhou o aluno que copiou o artigo'.

Em (a), a oração "who the scientist collaborated with" está encaixada dentro da outra relativa "who the professor... advised", que por sua vez está inserida na oração "The student... copied the article". Já em (b), as orações relativas estão encaixadas à direita da oração principal.

Nota-se que a compreensão de (a) é mais custosa do que de (b) porque cada oração relativa interrompe a oração na qual está encaixada. Sendo assim, o processamento da oração completa só é concluído após todos os elementos das orações encaixadas serem retidos na memória. No caso de (b), as orações encaixadas não interrompem a oração principal, a qual está totalmente processada até o momento da primeira relativa. Dessa forma, não há sobrecarga de memória nessas relativas finais. 
Em relação ao contraste entre relativas de sujeito e de objeto, tem-se observado, em várias línguas, uma assimetria no custo de processamento associado a essas orações. Nos exemplos supracitados de Gibson (2005), observa-se que, além do custo associado à posição de encaixamento da relativa, há também diferença quanto à posição sintática ocupada pelos pronomes relativos. Em (a), os pronomes relativos exercem função de objeto, enquanto que em (b) os pronomes relativos exercem função de sujeito.

Resultados de trabalhos conduzidos com adultos envolvendo diferentes técnicas experimentais (leitura automonitorada - King e Just (1991), Gibson (2005), Gouvea (2005); rastreamento ocular - Frazier (1989); Traxler, Morris e Rachel (2002); ERPs - King e Kutas (1995); tarefa de correspondência sentença-figura Costa et al. (2011) apontam para maior custo associado às relativas de objeto. Essa assimetria se observa até mesmo no caso de línguas em que a relativa é pré-nominal, como no caso do japonês, chinês e coreano (KWON et al. 2013).

Várias explicações têm sido apresentadas para justificar essa diferença. Conforme apresentado no capítulo 3, há, nas relativas de objeto, um efeito de intervenção do DP sujeito da relativa (FRIEDMAN, BELLETI e RIZZI (2009)), que como potencial candidato a antecedente da posição lacunada, torna o processamento mais difícil.

Outras propostas baseiam-se no grau de ativação do elemento relativizado na memória, em que a dificuldade de processamento é analisada em função da distância linear/temporal entre o elemento relativizado e a lacuna (GIBSON, 1998, 2000; WARREN e GIBSON, 2002; GIBSON et al., 2005)35.

Considerando que a compreensão de uma sentença envolve a integração de diferentes tipos de informações, restringida pelos recursos computacionais disponíveis, Gibson $(1998 ; 2000)$ propõe uma teoria - Teoria da Localidade da Dependência, Dependency Locality Theory (DLT) - que busca associar recursos computacionais a custos de processamento de integração e armazenamento envolvidos na compreensão de sentenças. Nesse modelo, considera-se que a complexidade de processamento durante o parsing é determinada pelo custo de

35 Kwon et al. (2013) mencionam também propostas que levam em conta a distância hierárquica entre o elemento relativizado e o gap (O’Grady's, 1997 - phrase-structural distance hypothesis) e propostas que estabelecem uma relação entre hierarquia de acessibilidade associada à posição da relativização e facilidade de processamento (KEENAN e COMRIE, 1977; HAWKINS, 1999, 2004). 
integração estrutural, relacionado à localidade ou distância entre os elementos que estão sendo integrados, e pelo processamento de elementos discursivos novos, que demandam mais recursos para serem processados.

Assim, o processo de compreensão de sentenças é baseado na ativação, visto que integrar uma nova projeção máxima (XP), cujo núcleo é $\mathrm{X}$, a uma projeção anterior (YP), cujo núcleo é $\mathrm{Y}$, requer manter aspectos de $\mathrm{X}$ na memória. À medida que novas palavras intervenientes vão sendo integradas à estrutura, essa ativação diminui, tornando o processamento mais difícil.

Quanto ao armazenamento, prevê-se que, para cada núcleo sintático que precisa ser retido, há o custo de uma unidade de memória, de modo que, quanto mais tempo uma categoria tiver que ser mantida na memória, maior será o custo desse armazenamento.

Levando em conta a teoria de Gibson, é possível prever, por exemplo, a partir de experimentos de leitura automonitorada, maior dificuldade de processamento, decorrente de maior custo de integração, de orações relativas de objeto em relação às de sujeito. Isso porque, há, nas relativas de objeto, entre o NP relativizado (sujeito da oração principal) e o verbo, que o toma como complemento (objeto direto), elementos intervenientes, incluindo o NP sujeito da relativa ("The reporter who the senator attacked admitted the error"), acarretando um custo de integração duas vezes maior do que nas de sujeito, em que apenas uma unidade deve ser integrada -o verbo- e a distância entre sujeito e verbo é local ("The reporter who attacked the senator admitted the error").

Na medida em que a Teoria da Localidade da Dependência de Gibson trata da utilização de recursos computacionais no parsing sintático, essas previsões de custo seriam propriedade geral das línguas e não só do inglês. A assimetria observada entre relativas de sujeito e de objeto também foi verificada em outras línguas, a partir de experimentos conduzidos em japonês (BABYONSHHEV e GIBSON, 1999 apud GIBSON, 2005), alemão (GIBSON, 2000), Português Europeu (COSTA et al., 2011) e, ainda, no Português do Brasil (GOUVÊA, 2005). Todos esses trabalhos, portanto, apresentam resultados compatíveis com a DLT de Gibson.

Em trabalho de 2005, Gibson et al. ampliam os estudos conduzidos até então sobre o custo de processamento- em termos de tempos de leitura - de orações relativas, considerando o tipo de encaixe (sem encaixe ou com encaixe), o tipo de 
relativa (sujeito e objeto), e também a função sintática do elemento modificado pela relativa (sujeito ou objeto). A partir da manipulação dessas três variáveis os autores pretendem testar a hipótese do custo de armazenamento.

O design experimental foi $2 \times 2 \times 2$, resultando em 8 condições, que estão ilustradas nos exemplos abaixo (GIBSON, 2005, p.320):

(34) Modificadora de sujeito, relativa de objeto (SO), não encaixada

a. The reporter who the senator attacked on Tuesday ignored the president.

'O repórter que o senador atacou na terça-feira ignorou o presidente'.

b. Modificadora de objeto, relativa de objeto $(\mathrm{OO})$, não encaixada

The president ignored the reporter who the senator attacked on Tuesday.

' $O$ presidente ignorou o repórter que o senador atacou na terça-feira'.

c. Modificadora de sujeito, relativa de sujeito (SS), não encaixada

The reporter who attacked the senator on Tuesday ignored the president.

'O repórter que atacou o senador na terça-feira ignorou o presidente'.

d. Modificadora de objeto, relativa de sujeito (OS), não encaixada

The president ignored the reporter who attacked the senator on

Tuesday.

' $O$ presidente ignorou o repórter que atacou o senador na terça-feira'.

e. Modificadora de sujeito, relativa de objeto (SO), encaixada

The fact that the reporter who the senator attacked on Tuesday ignored the president bothered the editor.

' $O$ fato de que o repórter que o senador atacou na terça-feira ignorou o presidente irritou o editor'.

f. Modificadora de objeto, relativa de objeto (OO), encaixada

The fact that the president ignored the reporter who the senator attacked on Tuesday bothered the editor.

' $O$ fato de que o presidente ignorou o repórter que o senador atacou na terçafeira irritou o editor.'

g. Modificadora de sujeito, relativa de sujeito (SS), encaixada 
The fact that the reporter who attacked the senator on Tuesday ignored the president bothered the editor.

' $O$ fato de que o repórter que atacou o senador na terça-feira ignorou o presidente irritou o editor.'

h. Modificadora de objeto, relativa de sujeito (OS), encaixada

The fact that the president ignored the reporter who attacked the senator on Tuesday bothered the editor.

' $O$ fato de que o presidente ignorou o repórter que atacou o senador na terçafeira irritou o editor.'

A partir da hipótese de armazenamento (GIBSON, 2000) era esperado que as relativas modificadoras de objeto, isto é, quando o NP antecedente da relativa está na posição de objeto direto, fossem mais fáceis de serem processadas, pois nesse caso a oração relativa não interrompe a oração em que está inserida - (b), (d), (f), (h).

Em relação à posição de extração da oração relativa (tipo de relativa - sujeito ou objeto), é prevista maior facilidade para as de sujeito, por envolverem menor custo de integração (GIBSON, 1998; 2000) - (c), (d), (g), (h). Por fim, espera-se que as relativas encaixadas - (e), (f), (g), (h) - sejam mais custosas para o processamento.

Os dados obtidos mostraram efeito principal para todas as variáveis examinadas, mas não houve interação entre elas. Foram confirmadas as previsões feitas em relação a encaixamento, com as encaixadas tendo tempos de leitura maiores, e à posição de extração (tipo de relativa), tendo as de objeto tempos maiores. Quanto ao termo modificado pela relativa (sujeito ou objeto), verificou-se que as relativas modificadoras de sujeito foram lidas mais rapidamente, contrariando as previsões feitas pelas hipóteses de armazenamento e integração.

Os autores explicam esse resultado a partir da formulação da hipótese do fluxo da informação (information-flow account). A ideia subjacente é que informações velhas, conhecidas, geralmente apresentadas na posição de sujeito, são processadas mais facilmente do que informações novas, expressas no predicado. Como orações relativas restritivas identificam um referente em um conjunto de entidades, usando para isso informações previamente conhecidas/compartilhadas por falante e ouvinte, é razoável supor que o processamento dessas orações torna- 
se mais fácil quando aparece no começo da sentença (em posição central), modificando o sujeito. Assim, ao lado das hipóteses de armazenamento e integração, essa terceira também tem papel atuante no processamento de estruturas relativas.

Motivada pela pesquisa de Gibson (2005), Gouvêa (2005) busca analisar o processamento online de orações relativas em função da posição de encaixe (central/ final) e da posição de extração (sujeito/objeto), no Português do Brasil e em Inglês a partir de diferentes técnicas experimentais. Além do trabalho de Gibson para o Inglês, a autora baseia-se em um trabalho anterior, utilizando uma tarefa offline, através da técnica apresentação Visual Serial Rápida (GOUVÊA, 2003), que apontou para maior dificuldade com relativas centrais em Português e, ao contrário, ausência de dificuldade no Inglês.

Neste trabalho mais recente, a autora quis avaliar o processamento de relativas na posição sintática de sujeito e objeto em função da posição de encaixamento, por meio da técnica de leitura automonitorada palavra a palavra. Os exemplos das condições experimentais e estímulos utilizados foram:

(35) a. Sujeito/ 1 encaixe central: O estudante que abraçou a colega de cabelo comprido insultou o professor depois do exame na escola pública.

b. Objeto direto / 1 encaixe central: $\mathrm{O}$ estudante que a colega de cabelo comprido abraçou insultou o professor depois do exame na escola pública.

c. Sujeito / 1 encaixe final: O professor insultou o estudante que abraçou a colega de cabelo comprido depois do exame na escola pública.

d. Objeto direto / 1 encaixe final: O professor insultou o estudante que a colega de cabelo comprido abraçou depois do exame na escola pública 3.

As orações relativas de objeto apresentaram maior dificuldade de processamento do que as de sujeito, tanto em PB como em Inglês37. Quanto ao encaixamento, a autora também encontrou resultados semelhantes para as duas

\footnotetext{
36A autora inseriu um PP "de cabelo comprido" após o NP "a colega" a fim de separar o NP do verbo principal nas orações centrais. Isso foi feito para evitar que qualquer dificuldade com a leitura do NP não se refletisse no verbo. Analogamente, foi inserido o advérbio de lugar "depois do exame" para separar o verbo da última região da sentença, de modo que uma possível dificuldade com o verbo da relativa ("abraçou") não recaísse sobre o advérbio "na escola pública".
}

37 A autora não apresenta os resultados estatísticos para essas variáveis. 
línguas. Tratando especificamente do $\mathrm{PB}$, o tempo residual de leitura - medido dentro da oração relativa - foi maior para as finais $(34,6 \mathrm{~ms})$ em oposição às centrais (16,8 ms), revelando que as orações relativas de encaixe final foram mais difíceis de serem processadas. A autora não é capaz, entretanto, de explicar a causa da dificuldade das orações relativas de encaixe final.

No que concerne aos resultados obtidos do cruzamento das variáveis, foi observado na região do verbo principal ("insultou") que as relativas de objeto com encaixamento central ("O estudante que a colega de cabelo comprido abraçou insultou o professor depois do exame na escola pública"), em que a oração relativa intervém entre sujeito e predicado da oração principal, tiveram tempos de leitura maiores, sugerindo que é o efeito combinado de posição (relativa de objeto) e encaixamento (central) que traz dificuldades ao processamento.

A diferença no processamento de relativas de sujeito e de objeto está prevista, também, na hipótese denominada Active Filler Strategy (FRAZIER, 1989), segundo a qual o parser, no curso do processamento, prevê a ocorrência de uma lacuna - e não de um sintagma - tão logo identifique o seu filler (antecedente). Portanto, o processador linguístico apresenta uma leitura incial das sentenças que envolvem movimento de constituintes, qual seja a de estabelecer a vinculação de um possível filler a um gap. A posição de sujeito é a que apresenta menor distância entre o filler e o gap, sendo a preferida pelo parser no processamento de relativas. Nas relativas de objeto direto, em que há a concorrência de dois NPs ao papel de antecedente, o estabelecimento dessa cadeia se torna mais difícil, levando a uma maior dificuldade de processamento.

Outro fator que parece afetar o processamento das relativas de objeto está relacionado à natureza dos referentes discursivos intervenientes. Em um teste de compreensão, Warren e Gibson (1999)38 aplicaram um questionário em que os participantes deveriam avaliar, a partir de uma escala de 1 a 5, o grau de dificuldade de compreensão de orações relativas. As sentenças utilizadas apresentavam uma gradação de complexidade, em função do tipo de NP usado na posição de sujeito mais encaixada, sendo a primeira considerada mais simples e a última mais difícil:

38 Também apresentado em Gibson (2000). 
(36) a. The reporter [who the senator [who $\underline{I}$ met] attacked] disliked the editor].

'O repórter [que o senador [ que $\underline{e u}$ conheci] atacou] desgostou do editor]'.

b. The reporter [who the senator [who $\underline{\text { John }}$ met] attacked] disliked the editor].

'O repórter [que o senador [ que $\underline{\text { John }}$ conheceu] atacou] desgostou do editor]'.

c. The reporter [who the senator [who the professor met] attacked] disliked the editor].

'O repórter [que o senador [ que $\underline{o \text { professor }}$ conheceu] atacou] desgostou do editor].'

A previsão dos autores é a de que, quando o sujeito da oração relativa encaixada é um pronome referencial, o processamento da sentença é mais fácil, pois nesse caso o referente é identificado pelo próprio contexto. Já quando o sujeito é representado por uma expressão referencial não pronominal, o processamento torna-se mais difícil.

Os resultados obtidos mostraram que, embora todas as sentenças apresentem o mesmo número de dependências, o grau de complexidade varia. A presença de um pronome de $1^{\mathrm{a}} / 2^{\mathrm{a}}$ pessoa, como em (36 a), torna a compreensão mais fácil, tendo em vista que esses referentes estão presentes no contexto discursivo, exigindo menos recursos de processamento e, portanto, menor custo de integração. O mesmo raciocínio explica o porquê de a presença de um nome próprio tornar uma sentença menos complexa do que um DP definido: o referente "John" (36 b) está mais acessível no contexto do que o DP "the professor" (36 c).

Ainda em relação à possível interferência de diferentes tipos de NP no processamento de relativas de sujeito e de objeto, Gordon, Hendrick e Johnson (2001) conduziram uma série de experimentos, a partir dos achados de Gibson (1998) e Gibson e Warren (1999).

Os experimentos foram feitos utilizando a técnica de leitura automonitorada seguida de um teste de compreensão que requeria a compreensão das relações sintático-semânticas entre os NPs e o verbo da oração principal. Além da diferença 
em relação ao tipo de tarefa, os estímulos usados também apresentavam estrutura diferente: as relativas eram tanto de sujeito (37 a), quanto de objeto (37 b) e não eram encaixadas. Abaixo, temos um exemplo:

(37) a. The banker that praised the barber climbed the mountain just outside the town before it snowed.

' $\mathrm{O}$ banqueiro que elogiou o barbeiro subiu a montanha fora da cidade antes de nevar'.

b. The banker that the barber praised climbed the mountain just outside the town before it snowed.

'O banqueiro que o barbeiro elogiou subiu a montanha fora da cidade antes de nevar'.

Em um primeiro experimento, contrastaram-se os tempos de leitura para relativas de sujeito e de objeto, que continham $\mathrm{SNs}$ definidos e relacionados a papéis humanos (barber). Os tempos de leitura para as relativas de objeto foram significativamente maiores em relação às de sujeito e a taxa de acerto menor, corroborando a ideia de que essas estruturas são mais difíceis de serem processadas do que as relativas de sujeito.

No segundo experimento, a posição de segundo NP foi ocupada por um pronome indexical (you), isto é, que depende do contexto para estabelecerem seus referentes, tais como os pronomes pessoais. Compatível com os resultados já descritos por Warren e Gibson (1999), a presença desse elemento torna o processamento mais rápido e fácil em comparação com NP definido. Além disso, não houve diferença significativa nos tempos de leitura entre os dois tipos de relativa na condição envolvendo o pronome referencial, sugerindo que esse fator reduz/elimina a assimetria existente.

Ainda na linha de Gibson, os autores encontraram o mesmo resultado quando o segundo NP era um nome próprio (Sue): o processamento foi significativamente mais rápido em relação aos NPs definidos. A comparação dos tempos de leitura dos dois tipos de relativa na condição com nome próprio não foi significativa.

Considerando que no modelo DLT o custo de processamento está relacionado à integração de novos referentes e que o NP próprio apresenta um novo referente que não está implícito na situação discursiva, nas relativas de objeto, em que o NP 
intervém entre componentes, era esperado que o custo de processamento fosse maior do que nas de sujeito. No entanto, os resultados foram contrários à previsão deste modelo, visto que a presença de um nome próprio como segundo NP tornou a interpretação das relativas de objeto tão fácil quanto as de sujeito. Esse resultado é explicado pelos autores à luz da similarity-based interference, em que constituintes de natureza similar estrutural ou semanticamente aumentam a complexidade do processamento, já que dificultam a recuperação do núcleo nominal, dada a semelhança entre os elementos, ao passo que itens de tipos diferentes tornam o processamento mais fácil.

Quando elementos semelhantes eram empregados nas sentenças, as relativas de objeto direto apresentaram maior dificuldade de processamento em relação às de sujeito. Isso porque, nessas, a integração de elementos é mais tardia e, como os dois núcleos nominais são semelhantes, é mais custoso manter a representação na memória, o que interfere no armazenamento da informação associada às duas representações.

Já quando se tem elementos de natureza diferente, essa diferença na dificuldade de processamento das relativas de objeto direto e de sujeito é diminuída ou eliminada, pois a presença de tipos diferentes de NPs reduz a interferência no armazenamento de informação. Esses dados refinam os resultados de trabalhos anteriores ao apresentar um novo fator que interfere no processamento das orações relativas, influenciando na maior ou menor complexidade dessas estruturas.

Compatível com esses achados é o trabalho de Corrêa et al (2012) para o PB, em que se assume um custo de processamento variável para as relativas de objeto em função da natureza referencial do antecedente a ser recuperado. Como vimos anteriormente, o processamento de uma oração relativa de objeto cujo elemento interveniente é um DP definido é mais custoso se comparado ao de uma oração relativa de objeto cujo elemento interveniente é um DP pronominal, mas esse custo pode ser relativizado de acordo com o imediatismo com que essa informação é recuperada em um dado contexto discursivo. Assim, para a compreensão dessas relativas, assume-se que não é necessário que o parser encontre o verbo para que possa estabelecer a correferência entre a lacuna (no interior da relativa), que ocorre em posição de argumento interno, e o DP antecedente (que se encontra externo à relativa), se determinados tipos de informação (visual e discursiva, por exemplo) 
que permitem a antecipação dessa relação são previamente disponibilizadas. Nas palavras dos autores,

Nesse caso, o referente do DP pode ser previsto, antes de a posição do gap ser preenchida. [...] A reativação do núcleo da relativa, mediante identificação do gap na posição de objeto, viria, nesse caso, confirmar o que foi antecipado. (CORRÊA, et al., 2012, p. 176-177)

Cabral et al (2015) investigam a possível atuação de traços semânticos, especificamente a animacidade, durante o parsing de orações relativas. Os autores pressupõem que o parser já teria acesso, desde o início do processo de compreensão, a informações de ordem semântica e que essas poderiam influenciar na maior ou menor facilidade do processamento. Essa visão contraria a visão modularista (FODOR, 1983; CHOMSKY, 1980), segundo a qual somente fatores sintáticos são considerados no momento inicial do processamento.

Tomando como ponto de partida estudo conduzido em holandês e alemão (MAK, et al., 2002), que indicou que o fator animacidade influenciou na compreensão de orações relativas, os autores replicaram em PB experimentos semelhantes ao realizado com falantes de holandês e alemão.

$\mathrm{O}$ primeiro experimento contrastou orações relativas de sujeito e de objeto que continham somente NPs animados e humanos (nomes próprios) empregando a técnica de leitura automonitorada. Cada uma das frases experimentais foi dividida em cinco segmentos, porém somente o segundo, que continha a oração relativa, e o terceiro, que poderia conter efeitos de espraiamento, foram analisados. Abaixo, exemplos de sentenças usadas:

(38) João/ que encontrou José/ naquele dia/ não quis/ pedir perdão.
$\mathrm{S} 1$
$\mathrm{S} 2$
$\mathrm{S} 3$
S4
S5

(39) João/ que José encontrou/ naquele dia/ não quis/ pedir perdão.
$\mathrm{S} 1$
S2
S3
S4
S5

Nesse primeiro experimento, os autores não manipularam o traço animacidade e a expectativa era de que as relativas de objeto fossem lidas mais lentamente do que as de sujeito, como já bem documentado na literatura. 
Trinta e um participantes realizaram o teste e, assim como esperado, os tempos de leitura para as relativas de objeto direto foram significativamente maiores em relação às de sujeito.

No segundo experimento, usando a mesma técnica do anterior e seguindo o mesmo procedimento, tomou-se também o fator animacidade como variável, gerando quatro condições experimentais: (i) sujeito [+ANIMADO]; (ii) sujeito [ANIMADO]; (iii) objeto direto [+ANIMADO]; (iv) objeto direto [- ANIMADO]. Para cada condição, foram criadas sentenças como:

(40) (i) A moça/ que alvejou o soldado/ na cena/ tinha menos de / vinte anos.

(ii) A arma/ que alvejou o soldado/ na cena / era considerada/ inofensiva.

(iii) A moça/ que o soldado segurou / na cena / tinha sido / sua namorada.

(iv) A arma/ que o soldado segurou/ na cena/ pertencia / à corporação policial.

Analisadas isoladamente, as variáveis tipo de relativa e animacidade não apresentaram resultados significativos, mas a interação entre as duas mostrou-se relevante estatisticamente. Esses resultados mostram, segundo os autores, que a assimetria entre relativas de sujeito e de objeto foi neutralizada devido à manipulação do fator animacidade, que nesse caso afetou os tempos de leitura. Ao contrastar os tempos médios obtidos para cada condição experimental, verificaram que as relativas de objeto inanimado foram as que demandaram menor custo de processamento em relação a todas as outras. Para os autores, o fato de todas as condições apresentarem a mesma estrutura encaixada do ponto de vista sintático, diferindo apenas quanto a animacidade, é indício de que esse traço já seria acessado pelo parser no início do processo de compreensão, contrariando propostas modularistas que defendem que informações de ordem semânticas não são acessadas pelo parser em um primeiro momento.

Ainda em PB, Kenedy (2007) investigou a compreensão de relativas preposicionadas $\mathrm{x}$ cortadoras por meio de uma tarefa de julgamento de gramaticalidade39 e de leitura automonitorada. Conforme mencionado no capítulo

$39 \mathrm{Na}$ tarefa, os participantes liam, na tela do computador, frases que continham orações relativas preposicionadas e, deveriam emitir, de forma imediata, julgamento de aceitável ou inaceitável. Cada frase permanecia na tela por 6 segundos. Após esse tempo, a frase era substituída por ???, que 
3, o autor parte da hipótese de que relativas pied-piping não fazem parte da gramática natural do falante, sendo fruto de aprendizagem formal e tardia. Assim, de acordo com a hipótese da anti-naturalidade de pied-piping, os participantes devem distinguir com facilidade cortadoras gramaticais de cortadoras agramaticais. Ao passo que encontrarão mais dificuldades em julgar a forma preposicionada como aceitável ou inaceitável. Além da variável tipo de relativa, cortadora ou piedpiping, foi manipulada a gramaticalidade das sentenças, em dois níveis: gramatical ou agramatical. Era esperado que a gramaticalidade de relativas cortadoras fosse julgada mais facilmente em relação às preposicionadas padrão. A seguir, exemplificamos as condições experimentais resultantes da manipulação das variáveis:

(41) a. Cortadora Gramatical (CG): O petróleo é um recurso natural que todas as economias dependem.

b. Cortadora Agramatical (CA): *O petróleo é um recurso natural o qual todas as economias dependem.

c. Preposicionada padrão Gramatical (PPG): O petróleo é um recurso natural de que todas as economias dependem.

d. Preposicionada padrão Agramatical (PPA): *O petróleo é um recurso natural de qual todas as economias dependem.

As variáveis dependentes foram tipo de julgamento (aceitável x inaceitável) e tempo de julgamento. Os 20 sujeitos que participaram da pesquisa estavam cursando o primeiro período de graduação, estando, portanto, inseridos em ambiente altamente letrado. Havia um total de 20 frases experimentais, organizadas por meio de um quadrado latino, e 40 distratoras. Cada participante foi exposto 5 vezes a cada uma das 4 condições experimentais. As frases eram apresentadas por inteiro na tela do computador por 6 segundos. Após esse tempo, os participantes deveriam julgar as sentenças.

Os resultados foram ao encontro da hipótese do autor, já que no contraste entre par, houve um efeito significativo $(\mathrm{p}<0,001)$ entre os julgamentos das condições CG e CA, que apresentaram, respectivamente, $72 \%$ e $28 \%$ de aceitação.

indicavam que o participante deveria emitir o julgamento, pressionando a tecla correspondente a cada julgamento. 
Já o contraste entre os julgamentos para PPG e PPA não foi significativo: as duas condições tiveram índice de aceitação muito próximos - 65\% e 61\%, sugerindo que os participantes aceitam, indistintamente, as duas formas como sendo gramaticais40. Esses resultados são interpretados como sendo favoráveis à hipótese da antinaturalidade de pied-piping (APP), revelando que cortadoras são percebidas como uma derivação natural, ao passo que os falantes demonstram dificuldade em avaliar as preposicionadas. Quanto aos tempos de julgamento, não houve diferença significativa em nenhum cruzamento feito.

Observações devem ser feitas, no entanto, quanto aos resultados desse experimento. Embora os julgamentos de gramaticalidade tenham apresentado resultados relevantes, a ausência de contraste significativo para as preposicionadas nos tempos demandados para processamento precisa ser considerada com mais atenção. Analisando os estímulos experimentais utilizados, nota-se que a agramaticalidade das orações cortadoras é mais nítida do que a das preposicionadas. Nessas, tanto a forma gramatical, quanto a agramatical são introduzidas pela mesma preposição (de, por exemplo), o que muda é a presença ou não do artigo definido junto à preposição: de que (gramatical), de qual (agramatical). Talvez a dificuldade de julgamento tenha se dado não pela preposição, mas sim pelo estranhamento gerado pela ausência do artigo definido depois da preposição na forma agramatical.

Em outro teste de julgamento de gramaticalidade, Kenedy buscou testar a hipótese da antinaturalidade de pied-piping, avaliando se analfabetos seriam capazes de distinguir relativas de pied-piping gramaticais de agramaticais. A hipótese é de que, sendo essas estruturas completamente estranhas à competência linguística dos falantes nativos de PB, não haverá a diferenciação entre sentenças gramaticais e agramaticais. Os resultados foram na direção esperada, mostrando que ambas as formas - gramatical e agramatical - foram, indistintamente aceitas. Para o autor, a insensibilidade demonstrada em relação à violação gramatical mostra que relativas de pied-piping não fazem parte da competência desses indíviduos. Um dado interessante foi que os sujeitos analfabetos aceitaram, preferencialmente, as formas agramaticais e gramaticais, em vez de terem negado as agramaticais ou oscilado em seus julgamentos. Segundo o autor, os analfabetos podem ter associado as estruturas de pied-piping a um suposto uso correto da língua.

${ }_{40} \mathrm{O}$ autor também aplicou o mesmo experimento com estudantes Portugueses, obtendo o mesmo resultado. 
Em síntese, o conjunto de trabalhos reportados nesta seção mostra que um conjunto de fatores de ordem sintática e semântica pode interferir nessa complexidade de processamento das orações relativas. Fatores como posição de origem do antecedente relativizado, função sintática na oração matriz do NP relativizado, posição do encaixamento, natureza dos elementos intervenientes (semelhantes ou não; NPs ou pronomes) e animacidade do antecedente e do elemento interveniente, interferem no processamento de orações relativas, tornando-as mais ou menos difíceis de serem processadas pelo parser.

\subsection{2}

\section{Processamento de orações relativas com resumptivos}

$\mathrm{Na}$ subseção anterior, apresentamos um levantamento de trabalhos que investigaram fatores que afetam o processamento de orações relativas. Nesta, forneceremos um panorama dos estudos envolvendo orações relativas com resumptivo, nos quais o processamento dessas estruturas é investigado de forma direta ou mesmo indireta, no âmbito de uma discussão mais ampla sobre o papel de resumptivos como estratégias de último recurso e sobre o papel de resumptivos na compreensão.

\subsubsection{1}

\section{Estudos em compreensão}

Conforme veremos, nas pesquisas em compreensão aqui reportadas, grande parte dos trabalhos não focaliza diretamente o processamento de relativas resumptivas. Na verdade, o foco é na discussão sobre os resumptivos serem ou não aplicados como último recurso. Nesse sentido, destaque é dado para estudos sobre aceitabilidade de sentenças, em especial de sentenças interrogativas complexas, envolvendo encaixamento de orações. Nesses trabalhos, interessa-nos, particularmente, verificar que fatores podem afetar a aceitabilidade desses elementos pronominais. $\mathrm{O}$ entendimento desses fatores pode ser informativo no exame dos contextos que podem ou não favorecer o emprego de relativas com resumptivo (vs. demais estratégias de relativização) em PB. 
No caso do Inglês, o resumptivo só é aceito em situações nas quais o movimento não é permitido (POLINSKY et al., 2013; MCDANIEL e COWART, 1999). Diante dessa premissa, vários estudos buscaram testar experimentalmente os julgamentos de estruturas com pronomes resumptivos com vistas a verificar a aceitabilidade desses elementos em contextos estruturais complexos, tais como os que envolvem violações de ilha e de múltiplos encaixamentos. A seguir apresentamos uma síntese dos principais trabalhos que investigam essas questões de um ponto de vista experimental.

Em relação ao papel dos resumptivos inseridos em contextos de ilhas sintáticas, uma variedade de trabalhos mostra que a aceitabilidade da estrutura pronominal, em comparação à lacuna, é maior quando esta ocorre em posição de extração de sujeito. A esse respeito, destacamos, primeiramente, o trabalho de McDaniel e Cowart (1999), por ter servido de ponto de partida para vários outros. Nesse estudo, os autores testaram a hipótese do pronome resumptivo como estratégia de último recurso, sendo empregado somente quando o movimento é ilícito, a partir da comparação da aceitabilidade dos pronomes resumptivos e lacunas inseridos em ilhas sintáticas fracas, como as orações completivas introduzidas por wh- em duas posições sintáticas: sujeito e objeto, como exemplificado a seguir:

(42) a. That's the girl that I wonder when (she/ -) met you.

'Esta é a garota que eu questiono quando (ela/ - ) conheceu você'.

b. That's the girl that I wonder when you met (her/-).

'Esta é a garota que eu questiono quando você conheceu (ela/ - )'.

Conforme já extensamente reportado na teoria linguística, contextos como (42 a) favorecem a ocorrência de um resumptivo, já que o movimento do NP relativizado é ilícito, dada a intervenção de uma ilha sintática fraca ("when you met”). A ausência do pronome provocaria a violação do Princípio da Categoria Vazia (ECP) - CHOMSKY (1981); MCDANIEL e COWART (1999); MCLOSKEY (1990). Ao contrário, em (43 b), em que há uma extração da posição de objeto direto, apesar de haver violação de movimento, a lacuna não é impedida de ocorrer, já que ela se encontra em posição de argumento interno do verbo e é 
tematicamente regido pelo verbo, não violando, portanto, o ECP. Dessa forma, o resumptivo não melhora a violação de ilha, e, portanto, não se prevê aceitabilidade diferenciada entre pronome e lacuna.

O teste de julgamento de aceitabilidade foi feito a partir de uma sentença de referência e utilizava uma escala de 10 pontos, por meio de um procedimento denominado de scannable line-drawing procedure 4 . Não houve diferença significativa entre resumptivos e lacunas na posição de objeto, mas a aceitabilidade dos pronomes nas de sujeito foi significativamente maior do que as lacunas. Importante ressaltar que o tipo de tarefa conduzida pode determinar os resultados obtidos. Ackerman (2018) mostra, por meio de diferentes experimentos, que os resumptivos são capazes de melhorar as violações de ilha em uma tarefa de escolha forçada. Dessa forma, a aparente discrepância entre resumptivos na produção vs compreensão seria determinada pelo viés metodológico, relacionado ao tipo de tarefa experimental.

Kefalla (2013) contrastou a aceitabilidade de resumptivos em oposição às lacunas em quatro tipos de estruturas: (i) não ilha; (ii) oração com that; (iii) ilha fraca com $w h$; (iv) ilha forte com oração relativa, nas posições sintáticas de sujeito e objeto direto. Os exemplos de estímulos usados em cada condição são apresentados a seguir:

\section{Sujeito}

a) Sem ilha

b) Sem ilha (oração com "that")

c) Ilha fraca com elemento"QU-"

d) Ilha forte (oração relativa)
This is the chef that (she) prepared the potatoes. This is the chef that Ted realized that (she) prepared the potatoes.

This is the chef that Ted inquired how (she) prepared the potatoes.

This is the chef that Ted devoured the potatoes that (she) prepared.

\section{Objeto}

These are the potatoes that Ted prepared (them).

These are the potatoes that Ted realized that the chef prepared (them).

These are the potatoes that Ted inquired how the chef prepared (them).

These are the potatoes that Ted flirted with the chef that prepared (them).

Tabela 3: Condições experimentais do experimento de Keffala (2013)

${ }_{41}$ " [...] this procedure required subjects to report their judgments via a ten-point scale on a standard machine-readable response form. They were taught to regard each series of response values as a line. This imaginary line begins at the left edge of the series and each score value corresponds to a possible rightward end point for that line. A reference sentence presented at the outset of the judgment task was assigned a value of 5. Each response indicated how much better or worse than the reference sentence each sentence seemed." (MCDANIEL e COWART, 1999, p. 20). 
A hipótese subjacente é que resumptivos apresentam nível de aceitabilidade uniforme entre as condições, ao passo que a aceitabilidade das lacunas é variável. Na linha do que McDaniel e Cowart (1999) investigaram, a autora acredita que nos casos em que as lacunas violam restrições de ilha e criam efeitos do Princípio da Categoria Vazia (ECP) - orações completivas encabeçadas por that -, os pronomes resumptivos seriam mais aceitos.

Para a condição envolvendo ilhas (c e d), os resultados obtidos foram convergentes com os obtidos pelos autores anteriores, já que os resumptivos só foram mais aceitos que as lacunas na posição de sujeito, em que houve violação do ECP. Neste mesmo tipo de estrutura, para a posição de objeto, não houve diferença significativa entre lacunas e resumptivos.

No entanto, para a condição sem ilha (a e b), em que o ECP também é violado, a aceitabilidade dos resumptivos mostrou-se inferior à das lacunas, contrariando a proposta de McDaniel e Cowart (1999), para quem os resumptivos são manifestações de traços que ocorrem quando o vestígio é ilícito e este princípio é desrespeitado.

Analisando as médias de nota para cada condição, a autora confirmou a hipótese de que a aceitabilidade dos resumptivos não flutua, ao passo que as lacunas apresentam maior variação nos julgamentos:

English has not grammaticized the use of pronouns as 'true' resumptives (Sells 1984), structures that contain resumptive pronouns are just consistently rated as marginal, and receive some sort of uniform penalty. (KEFFALA, 2013, p. 152)

$\mathrm{Na}$ interpretação da autora, a baixa e uniforme aceitabilidade dos resumptivos reflete a dificuldade de processamento imposta por esses elementos, a qual reside na necessidade de o parser reinterpretar a sentença ao se deparar com um pronome resumptivo no lugar de uma lacuna, gerando custo de processamento. Esses resultados e essa análise feita pela autora estão em diálogo com a proposta de Frazier (1989), na medida em que o parser prevê a existência de uma lacuna na posição de onde o filler foi extraído. Ao se deparar, no entanto, com um pronome, uma releitura necessita ser feita, a fim de determinar a referência entre pronome e antecedente. 
Utilizando uma outra técnica experimental, qual seja estimativa de magnitude, Han et al. (2012) também investigaram a aceitabilidade dos resumptivos vs. lacunas em função da posição sintática (sujeito x objeto direto) e do tipo de sentença (ilha/não ilha). Foram conduzidos dois experimentos, variando somente na forma de apresentação dos estímulos: texto e áudio.

Os resultados convergem na direção da literatura sobre tema. A análise estatística não mostrou diferença significativa entre as condições com pronome, ou seja, a aceitabilidade de resumptivos é baixa em todas das condições, ao contrário das lacunas, que apresentaram variação na aceitabilidade, nos moldes do que obteve Kefalla (2013). Os autores defendem que essa preferência baixa e uniforme, não é devido ao resumptivo

but is due to the fact that the subject empty gap isle relatives have a very low acceptability, as compared to the object empty gap isle relatives, a well-documented fact in theoretical syntax (CHOMSKY, 1981; RIZZI, 1990), which is also replicated by our experiments. (HAN et al., 2012, p.157)

A forma de apresentação dos estímulos (escrito e por áudio) não parece ter influenciado os resultados: ambos os experimentos apresentam evidências de que os pronomes resumptivos são pouco aceitos.

Os autores explicam a assimetria entre dados de produção e de compreensão dos resumptivos na linha do que propõem Alexpoulou e Keller (2007) e também Frazier (1999) e Hawkins (1999). Na produção, os falantes têm disponíveis duas estratégias: a de movimento e a de anáfora, mas, na compreensão, parece haver prioridade para a de movimento, o que se refletiria na baixa aceitabilidade dos resumptivos. Assim, defendem que, na compreensão, o parser assume, por default, uma interpretação considerando movimento e, ao se deparar com o pronome, precisa mudar para uma estratégia anafórica, porém o custo de processamento envolvido na interpretação da sentença até o ponto em que o pronome é encontrado não é eliminado, o que acarreta a baixa aceitabilidade.

Em um trabalho anterior, as autoras Alexpoulou e Keller (2007) analisaram não só o comportamento dos resumptivos (vs. lacunas) em situações com e sem violação de ilhas sintáticas (fortes: formada por orações relativas e fracas: perguntas indiretas), como também manipularam a profundidade de encaixamento dos pronomes, medida em relação à quantidade de orações intervenientes, podendo ser 1 (oração relativa ou completiva) ou 2 (uma oração relativa ou completiva 
encaixada em outra) em três diferentes línguas: inglês, alemão e grego. Para cada uma das variáveis, havia a condição controle em que não havia ilha sintática e nem encaixamento.

Os tipos de estímulos usados pelas autoras foram:

(43) Sem violação de ilha:

a. Who will we fire $\mathrm{t} / \mathrm{him}$ ? (sem encaixamento)

'Quem de nós irá demitir t/ele?'

b. Who does Mary claim that we will fire t/him? (um encaixe)

'Quem Mary afirma que nós iremos demitir t/ele?"

c. Who does Jane think that Mary claims that we will fire t/him? (duplo encaixe)

'Quem Jane acha que Mary afirma que nós iremos demitir t/ele?'

\section{Violação de ilha fraca}

a. Who does Mary wonder whether we will fire $t / h i m$ ? (um encaixe)

'Quem Mary imagina que nós iremos demitir t/ele?'

b. Who does Jane think that Mary wonders whether we will fire t/him? (duplo encaixe)

'Quem Jane pensa que Mary imagina que nós iremos demitir t/ele?'

\section{Violação de ilha forte}

a. Who does Mary meet the people that will fire $t / h i m$ ? (um encaixe)

'Quem Mary conhece as pessoas que demitirão t/ele?'

b. Who does Jane think that Mary meets the people that will fire t/him? (duplo encaixe)

'Quem Jane pensa que Mary conhece as pessoas que demitirão t/ele?'

Utilizando a técnica de estimativa de magnitude, os dados indicaram que os pronomes resumptivos não salvam violações de ilha, seja em ilha forte ou fraca, sendo em todos esses casos menos aceitos que as lacunas. A aceitabilidade aumenta quando o grau de encaixamento é maior - acima de 2 -, embora não chegue a superar a lacuna. 
Cabe ressaltar, no entanto, que as autoras investigaram somente orações interrogativas em que o pronome exerce função de objeto direto, o que pode explicar os resultados obtidos.

As autoras defendem que os pronomes resumptivos estabelecem uma dependência anafórica (e não sintática) que é mais facilmente construída em longa distância do que a dependência criada com lacunas. Apesar disso, dependências construídas com resumptivos não são livres de custo, tendo em vista que o parser assume a existência de uma dependência com lacuna e, ao se deparar com o resumptivo, deve promover uma busca pelo seu antecedente, o que gera um custo.

Ampliando esse trabalho, Heestand et al (2011) consideram a assimetria existente entre a ocorrência de resumptivos na produção e sua pouca aceitação na compreensão e assumem a hipótese de que, na produção, os pronomes resumptivos são um mecanismo que auxilia o falante a manter o controle sobre as relações de correferência, mas, em contrapartida, na compreensão, não facilitam o processamento. A ocorrência de resumptivos na produção deve-se, segundo os autores, às restrições de tempo42 impostas aos falantes no momento da produção43 (HEESTAND et al., 2011, p. 8).

Os autores conduziram dois experimentos: o primeiro replicando a técnica de Alexopoulou e Keller (2007), com apresentação escrita dos estímulos, e o segundo usando estímulos auditivos, a fim de garantir o contexto natural (predominantemente oral) de maior ocorrência da forma resumptiva. Em todos os estímulos, o resumptivo estava na posição de objeto direto. Foram incluídas, além de interrogativas, sentenças declarativas (envolvendo relativas, com lacuna/pronome resumptivo em uma ilha - ex.: "This is the man that the policeman who arrested_/him saved the President's life" ou adjuntos, com lacuna/pronome resumptivo no interior de uma ilha - ex.: "This is the dish that, although the chef overcooked_it, the guests were not upset") e estabeleceu-se na compreensão a mesma pressão de tempo (pouco tempo para resposta e sem possibilidade de registro escrito da resposta) da produção. O primeiro experimento consistiu em

\footnotetext{
42 Nestes experimentos, o tempo de resposta era limitado de modo a evitar que o participante pudesse estudar a sentença - embora os autores não especifiquem de quanto era o tempo -, cada estímulo era apresentado uma única vez e não era permitido fazer anotações.

43 Os autores citam o trabalho de Ferreira e Swets (2005) como evidência de que a produção de resumptivos está atrelada a demandas de processamento (pouco planejamento da fala). Além disso, os autores falam que estudos de corpus e de produção atestam a alta frequência de resumptivos na produção. No entanto, os autores não mencionam referências desses trabalhos.
} 
leitura automonitorada palavra por palavra seguida de uma tarefa de julgamento de aceitabilidade off-line. $\mathrm{O}$ segundo experimento foi um estudo piloto de julgamento de aceitabilidade online usando áudio e somente frases declarativas. A seguir apresentamos exemplos das sentenças testadas pelos autores:

(44) Ilhas sintáticas formadas por relativas, em declarativas (a) e interrogativas (b):

a. This is the man that the policeman who arrested _ / him saved the President's life.

'Este é o homem que o policial que prendeu __ele salvou a vida do presidente'.

This is the man that the policeman who arrested the thief saved (Controle)

'Este é o homem que o policial que prendeu o ladrão salvou a vida

b. Which person did Mary think that the policeman who arrested / him saved the President's life?

'Que pessoa Mary achou que o policial que prendeu _ _ ele salvou a vida do presidente?'

Which man did Mary think that the policeman who arrested the thief saved_? (Controle)

'Que homem Mary achou que o policial que prendeu o ladrão salvou $/ ?^{\prime}$

(45) Ilhas sintáticas formadas por adjuntos, em declarativas (a) e interrogativas (b):

a. This is the dish that, although the chef overcooked _ / it, the guests were not upset.

'Este é o prato que, embora o chefe tenha cozinhado demais __ ele, os convidados não ficaram chateados'.

This is the dish that, although the chef overcooked the sauce, the guests enjoyed (Controle)

'Este é o prato que, embora o chefe tenha cozinhado demais o molho, os convidados gostaram

b. Which dish did Gina think that, although the chef overcooked _ / it, the guests were not upset?

'Que prato Gina achou que, embora o chefe tenha cozinhado demais __ele, os convidados não ficaram chateados?' 
Which dish did Gina think that, although the chef overcooked the sauce, the guests enjoyed __? (Controle)

'Que prato Gina achou que, embora o chefe tenha cozinhado demais o molho, os convidados gostaram __?'

Os resultados deste primeiro experimento indicaram que, independentemente de apresentarem lacuna ou resumptivo, as orações interrogativas são menos aceitas do que as declarativas. Na direção do resultado obtido por McDaniel e Cowart (1999), não houve diferença significativa na aceitabilidade de lacunas e pronomes resumptivos.

Especificamente em relação aos tempos de leitura, a única diferença significativa observada foi para as perguntas QU-, nas quais os resumptivos apresentaram tempos menores que as sentenças controle. Nas declarativas, o tempo de leitura das orações resumptivas foi menor, mas marginalmente significativo do ponto de vista estatístico $(\mathrm{p}=.08)_{44}$.

No segundo experimento, em que os estímulos foram apresentados por meio de áudio, também não houve diferenças significativas na aceitabilidade de pronomes e lacunas em ambos os tipos de orações.

Juntos, os resultados dos dois experimentos mostram que os resumptivos não são bem aceitos, sendo incapazes, portanto, de "salvar" violações de ilha. Apesar disso, são frequentes na fala. A despeito dessa aparente disparidade entre ocorrência de resumptivos na produção $v s$. baixa aceitação na compreensão, os autores defendem que o falante, no ato da produção, considera somente seus próprios interesses, sem se ater às necessidades do seu ouvinte, diante das pressões de desempenho (situações de pouco planejamento, natureza incremental da produção, etc), que o fazem utilizar os resumptivos para a manutenção da correferência.

Beltrama e Xiang (2014) investigaram o papel facilitatório dos resumptivos na compreensão de sentenças em Inglês e Italiano. Nas duas línguas, apesar de ser considerado agramatical, o pronome resumptivo é bem aceito em contextos em que há violação de ilha. Diferentemente do Inglês, porém, em Italiano, o pronome resumptivo é licenciado em estruturas que envolvem topicalizações.

${ }_{44}$ Os autores assumem no texto que o valor de $\mathrm{p}=.08$ é marginalmente significativo, embora, na literatura, essa seja uma questão controversa. 
Esta pesquisa apresenta uma importante contribuição metodológica em relação aos trabalhos anteriores, que é o foco na compreensão em detrimento da aceitabilidade, e na apresentação dos estímulos em um contexto prévio, tornando o referente mais acessível.

Um exemplo de estímulo utilizado pelas autoras é:

(46) Contexto prévio: Yesterday there were riots in the street, e some people were wounded by the police. Oh my, have you heard about this?

Ieri ci sono stati disordini per strada, e alcune persone sono rimaste ferite dalla polizia.

'Ontem havia tumultos na rua e algumas pessoas foram feridas pela polícia. Ah, você ouviu sobre isso?'

Oração alvo: This is the boy that the cop who was leading the operation arrested (him/ /)!

Questo è il ragazzo che il poliziotto che $\left\{1^{\prime} / \ldots\right\}$ picchiato deve essere sospeso.

'Este é o garoto que o policial que estava conduzindo a operação prendeu $(\mathrm{ele} /)$ !'

As três variáveis independentes manipuladas foram: ilha (oração relativa gramatical/oração relativa agramatical, com violação de ilha); tipo de retomada (resumptivo ou lacuna); encaixamento (dois ou três níveis):

(47) a. Ilha / 2 ou 3 níveis de encaixamento: This is the guy that (the newspaper reports that) the cop who led the operations $\{$ him/_ $\}$ has beaten.

'Este é o cara que (os jornais dizem que) o policial que conduziu as operações foi agredido.'

"This is the guy that (the paper reports that) the cop who was leading the operation beat $\{\mathbf{h i m} / \ldots\}$ up”.

'Este é ocara que (o jornal diz que) o policial que estava conduzindo a operação agrediu $\{$ ele/ __ $\}$ '.

Para o Italiano, em contextos de ilha, os resumptivos receberam notas maiores do que lacunas. O nível de encaixamento, em contextos fora de ilha, dificultou a compreensão das orações com lacunas, mas não dos resumptivos. 
Dentro de ilhas, não houve diferença significativa do encaixamento para os dois tipos de relativa.

Assim, os resumptivos parecem favorecer a compreensão em contextos em que há uma ilha sintática, mas não ajudam quando a dependência é longa, tendo em vista que não houve diferença na compreensão de lacunas e de resumptivos nos dois níveis de encaixamento testados.

O mesmo experimento foi replicado em Inglês, com a diferença que os estímulos foram apresentados na forma escrita. Assim como no Italiano, dentro de ilhas sintáticas, os resumptivos receberam julgamentos melhores que as lacunas. Considerando a variável encaixamento, as lacunas receberam notas mais altas em estruturas com 2 encaixamentos do que em estruturas com 3 . Não houve diferença significativa para os resumptivos.

Os resultados das duas línguas mostram que o papel facilitador dos resumptivos em contextos de dependências complexas não está atrelado a parâmetros específicos de uma única língua, parecendo refletir características comuns a diferentes gramáticas.

Em relação à ausência de efeito significativo para a variável encaixamento, as autoras explicam que, pelo fato de as orações diferirem em apenas um nível de encaixamento, o papel facilitador dos resumptivos pode não ter sido detectado. Por outro lado, porém, as autoras defendem que os pronomes resumptivos apresentam um efeito indireto de facilitação de processamento, na medida em que, apesar de não melhorarem a compreensão em dependências sintáticas mais longas (três encaixamentos), evitam que as sentenças se tornem piores, como acontece com as lacunas em contextos sem ilha, mas com 3 níveis de encaixamento.

Baseado em estudos prévios (HEESTAND et al., 2011; ALEXOPOULOU e KELLER, 2003) que sugerem que os resumptivos auxiliam na compreensão em orações relativas com dependências mais longas, Hofmeister e Norcliffe (2013) conduziram dois experimentos com vistas a investigar o papel dos resumptivos na compreensão. Assim como o trabalho de Heestand et al. (2011), dados de processamento são confrontados com dados de julgamento de aceitabilidade, por meio de dois experimentos.

No primeiro, investigou-se como resumptivos afetam os julgamentos de aceitabilidade em sentenças com diferentes graus de complexidade de processamento. 
O julgamento de aceitabilidade foi feito utilizando a metodologia do julgamento do termômetro (thermometer judgment). Nessa tarefa, os participantes deveriam julgar os itens baseados em duas sentenças de referência, uma ruim e outra boa, atribuindo os valores arbitrários 20 e 30. Cada sentença era apresentada palavra a palavra de forma automática e era seguida de uma pergunta de compreensão.

Diferentemente dos outros estudos reportados, neste, os resumptivos aparecem inseridos em orações relativas. As variáveis independentes manipuladas foram: tamanho da dependência (longa $\mathrm{x}$ curta) e tipo de relativa (lacuna $\mathrm{x}$ resumptivo). Na condição de dependência longa, entre o referente e seu antecedente havia duas orações - relativa e completiva -, enquanto que, na de dependência curta, apenas a oração relativa intervinha entre os elementos. A seguir apresentamos exemplos de sentenças usadas pelos autores, em que (a) e (b) ilustram uma dependência longa, e (c) e (d) uma dependência curta, sem e com resumptivo, respectivamente:

(48) a. Mary confirmed that there was a prisoner who the prison officials had acknowledged that the guard helped to make a daring escape.

'Mary confirmou que havia um prisioneiro que os agentes penitenciários tinham conhecimento que o guarda ajudou a fazer a ousada fuga'.

b. Mary confirmed that there was a prisoner who the prison officials had acknowledged that the guard helped him to make a daring escape.

'Mary confirmou que havia um prisioneiro que os agentes penitenciários tinham conhecimento que o guarda ajudou ele a fazer a ousada fuga'.

c. The prison officials had acknowledged that there was a prisoner that the guard helped to make a daring escape.

'Os agentes penitenciários tinham conhecimento de que havia um prisioneiro que o guarda ajudou a fazer uma ousada fuga'.

d. The prison officials had acknowledged that there was a prisoner that the guard helped him to make a daring escape.

'Os agentes penitenciários tinham conhecimento de que havia um prisioneiro que o guarda ajudou ele a fazer uma ousada fuga'. 
A hipótese que se assumiu foi a de que sentenças mais complexas (i.e., dependências longas) impõem maior dificuldade de processamento em relação às mais curtas.

Os resultados, analisados a partir dos modelos lineares de efeitos mistos (LMEMs), indicaram efeito principal de ambas as variáveis no julgamento dos itens. Os resumptivos foram menos aceitos do que as lacunas nos dois tipos de dependência. Além disso, dependências longas receberam julgamentos inferiores às curtas. Apesar da preferência por lacunas em ambas condições, houve uma interação significativa entre tamanho da dependência e resumpção: a rejeição dos pronomes em sentenças na condição longa foi menor. Assim, embora os pronomes resumptivos não tornem as sentenças melhores, são menos rejeitados em contextos de difícil processamento, como no caso das dependências longas. Já a comparação entre tipo de relativa e tipo de dependência mostrou que a diferença na aceitabilidade de resumptivos é 2.5 vezes menor nas dependências curtas do que nas longas. Ou seja, embora resumptivos sejam menos aceitos que lacunas, em contextos de maior dificuldade de processamento, como em dependências mais longas, a aceitabilidade do pronome é maior, conforme já previsto por Alexopoulou e Keller (2007); Heestand et al. (2011).

Hofmeister e Norcliffe (2013) apresentam duas hipóteses para explicar os achados. A primeira prevê que a saliência da violação causada pela presença do pronome é reduzida dada a distância entre os referentes. A segunda estabelece que o pronome pode exercer uma função em dependências longas, que é facilitar o processamento, sendo por isso mais aceito nesses contextos. Para testar essas duas hipóteses, foi feito um segundo experimento de leitura automonitorada online. Os autores partem da previsão de que os resumptivos não tornam o processamento mais rápido em nenhum contexto.

Os tempos residuais de leitura da região crítica, formada pelas duas palavras seguindo o resumptivo/a lacuna, foram analisados e apontam para o papel facilitador dos resumptivos em dependências longas, já que os tempos de leitura nessa condição foram os menores de todas as condições. No entanto, os resultados obtidos nos dois experimentos não permitem, à primeira vista, tecer um paralelo entre restrições estruturais e de processamento, já que a rapidez de processamento dos resumptivos em estruturas complexas não correspondeu à maior aceitabilidade dos itens. Para os autores, a baixa aceitabilidade dos pronomes resumptivos parece 
estar relacionada a restrições estruturais que impedem a sua ocorrência, apesar de facilitarem o processamento, medido em termos de tempo de leitura.

Em suma, o conjunto de trabalhos reportados converge para a ideia de que, apesar de serem elementos poucos aceitos na compreensão, contextos sintáticos de maior complexidade podem reduzir essa rejeição aos pronomes resumptivos.

\subsubsection{2}

\section{Estudos em produção}

Poucos trabalhos têm se concentrado na produção. Um desses é o de Ferreira e Swets (2005), que conduziram dois experimentos para eliciar a produção de resumptivos, que depois tiveram sua aceitabilidade julgada pelos mesmos participantes. Partindo da ideia de que estruturas como resumptivos emergem por pressões impostas no momento da produção, no primeiro experimento, os participantes não tinham tempo determinado para iniciarem a produção. Já no segundo, os participantes possuíam até $1750 \mathrm{~ms}$ para iniciarem a produção.

A previsão das autoras era de que, em condições em que há pressões de tempo, os participantes demorariam mais tempo para darem início à produção.

A tarefa consistia na apresentação de 3 figuras, as duas primeiras servindo como descritoras e a última com a informação a ser completada. A ideia é que as sentenças descritoras levem à produção da estrutura pretendida, formada por ilha com resumptivo.

Os tempos de iniciação e de duração das palavras foram medidos em comparação às sentenças-controle.

Os estímulos foram organizados em duas listas com 48 arranjos em cada uma. Cada arranjo era constituído por 3 figuras com 3 descrições. Após analisarem o trio de imagens e descrições, os participantes respondiam à pergunta "What is this?" para a primeira descrição (conforme ilustrado na figura 1), utilizando de uma sentença completa formada por pelo menos um substantivo, um verbo e o conteúdo da descrição. Após descreverem a primeira imagem, os participantes respondiam à mesma pergunta para as próximas duas figuras em cada slide, sendo que a terceira correspondia à resposta a ser analisada pelas pesquisadoras, formada por "don't know" (ilha +resumptivo), ou "doesn't know" (controle). As figuras utilizadas foram do tipo: 


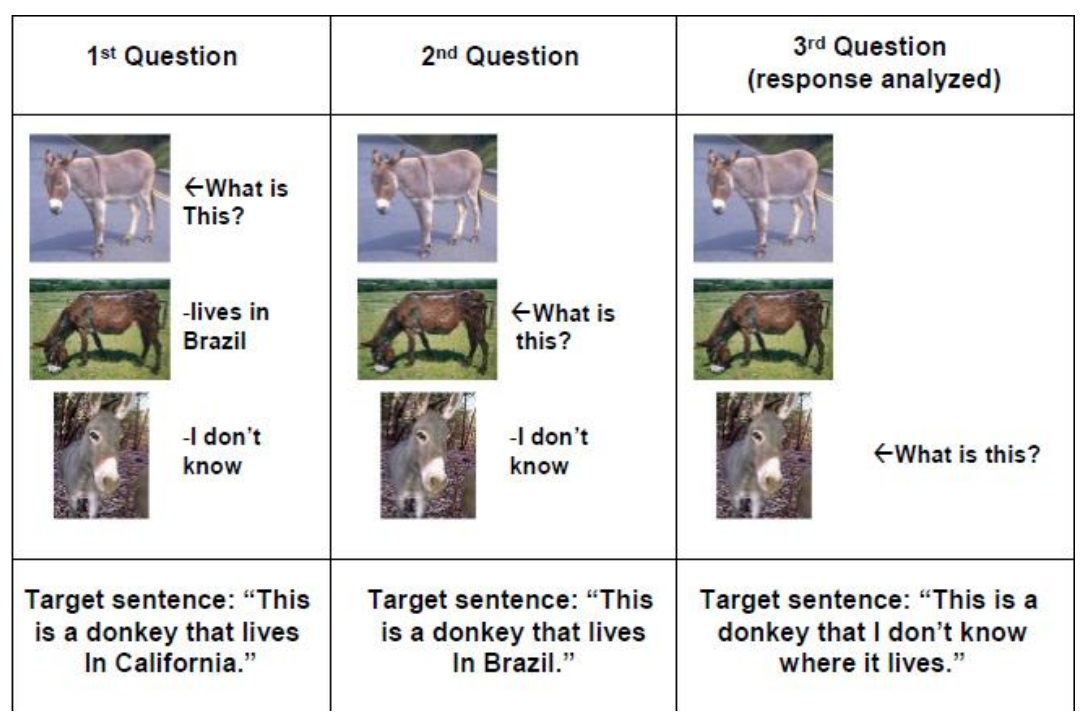

Figura 1: Imagem usada no experimento de Ferreira e Swets (2005)

Os participantes viram uma figura por vez e, após cada uma, ouviam a pergunta "What is this?", que deveria ser respondida com uma sentença contendo um nome, um verbo e o conteúdo da descrição, como, por exemplo, "This is a donkey that I don't know where it lives". Para análise, foi considerado o tempo de iniciação da segunda oração até o início da última ("where it lives") da descrição da última figura de cada trio.

Em ambos os experimentos, o tempo de duração das orações formadas por ilha + resumptivos foi maior em relação ao das sentenças-controle e o tempo de produção da oração "where it lives" foi significativamente maior do que "that I don’t know”, sugerindo que essas estruturas são mais difíceis de serem processadas. De igual modo, os tempos de iniciação das orações com resumptivos foram maiores, embora a diferença não tenha sido significativa em relação à outra condição nos dois experimentos. Ainda, a pressão de tempo imposta no segundo experimento fez com que os participantes iniciassem a produção mais cedo, em média, pela metade do tempo. Comparando os tempos de duração de segmentos das sentenças em ambos os experimentos, verifica-se que, quando não há tempo limite para produção, a dificuldade de processamento surge logo no início, dada a alta duração verificada já no núcleo da oração relativa, o nome "donkey". Ao contrário, quando havia pressão de tempo para produção, a dificuldade de processamento aparecia mais tarde na sentença, a partir do complementizador "that". Segundo as autoras, esses dados mostram que o sistema de produção da linguagem atua de 
forma mais incremental em contextos de pressão de tempo. Isso é evidenciado pelo baixo tempo de iniciação e também de duração total da sentença. Ao contrário, quando não é estabelecido um tempo limite para produção e, portanto, há mais tempo para planejamento da mensagem, a produção não ocorre de forma totalmente incremental, o que se revelou, no experimento 1, em tempos de iniciação e duração maiores em relação ao segundo.

Nota-se, portanto, que a ocorrência de resumptivos na produção é frequente, como já sinalizado em outros trabalhos e até mesmo pela intuição linguística. Essas estruturas, entretanto, quando submetidas a um teste de julgamento de aceitabilidade, não são bem aceitas, revelando uma assimetria entre os sistemas de produção e de compreensão.

Surpreendentemente, a frequência de ocorrência de resumptivos em situações de pouco planejamento foi menor do que naquelas de maior planejamento45. Esses resultados divergem da crença de que a produção dessas estruturas (ilha+ resumptivo) está relacionada a contextos de pouco planejamento. Os participantes optaram por outras formas para evitar a produção dessas estruturas com resumptivos, como alternativas envolvendo coordenação ("This is a donkey and I don't know where it lives") e deslocamento à esquerda (“This donkey, I don't know where it lives"). Esse resultado se assemelha aos obtidos em PB (conforme veremos adiante), em que os participantes recorreram a outras estratégias para não utilizar resumptivos (GROLLA e AUGUSTO, 2016; CORRÊA et al., 2018).

Tendo em vista a existência de poucos estudos dedicados à produção de resumptivo, Morgan e Wagers (2018) buscam caracterizar sua distribuição em contextos mais amplos por meio de tarefa de produção controlada. Além disso, buscam oferecer uma perspectiva conciliatória entre dados de produção e compreensão, motivo pelo qual apresentaremos nessa subseção não só o experimento conduzido em produção, mas também em compreensão.

Na primeira atividade experimental, os participantes eram apresentados a uma sentença base (49 a) e então a uma sentença padrão (que continha o início de uma oração relativa - 49 b) que deveria ser completada:

45 Embora as autoras afirmem que a diferença foi estatisticamente significativa, os valores de p não foram apresentados. 
(49) a. The News that the alien dissected the woman shocked Karl.

'A notícia de que o alienígena dissecou a mulher chocou Karl'.

b. I know the woman who the news that

'Eu conheço a mulher que a notícia que

A ideia subjacente é que a frase produzida contivesse uma lacuna ou resumptivo. As variáveis manipuladas foram (i) posição sintática do lugar de extração: sujeito ou objeto e (ii) domínio de encaixamento (local de extração), em 6 níveis: Emb 1 (encaixamento único sem ilha), Emb 2 (encaixamento duplo sem ilha), Completivas QU-, adjuntos, sujeitos complexos, objetos complexos.

Conforme pode-se observar, foram examinados neste experimento diferentes ambientes sintáticos e não só em dependências de ilha sintática, o que permite-nos obter uma visão mais abrangente acerca da ocorrência de resumptivos na produção.

Os resumptivos foram mais frequentes em estruturas mais encaixadas, e, portanto, mais complexas. Os resultados sugerem que a produção de resumptivos depende do contexto sintático, sendo incomuns, por exemplo, em estruturas mais simples, que envolvem a posição de um sujeito mais alto e mais frequentes quando a posição de extração do sujeito está dentro de uma ilha sintática.

Em um segundo experimento, os autores investigaram a aceitabilidade das sentenças produzidas no primeiro, tendo como hipótese que a produção de um pronome resumptivo está atrelada à sua aceitabilidade.

Os resultados indicam que à medida que a aceitabilidade da lacuna cai, a frequência de produção de um resumptivo nessa estrutura aumenta. A partir desses achados, os autores defendem que há uma relação entre sistema de produção e compreensão, de tal modo que a produção de um pronome resumptivo estará relacionada à baixa aceitabilidade de uma lacuna. Essa interpretação busca resolver uma questão central na literatura sobre resumptivos que é a assimetria existente entre produção e compreensão. Levando em consideração o modelo de produção de Levelt (1989), os autores assumem que, em um dado momento da produção antes da ocorrência de uma lacuna, o parser verifica a aceitabilidade da estrutura planejada. Em caso de a lacuna não ser aceita, o pronome resumptivo tenderá a ser produzido. Desse modo, a produção dessa estrutura pronominal seria proporcional, nessa hipótese, à baixa aceitabilidade da lacuna. 
Ainda quanto à produção de relativas resumptivas, destaca-se o trabalho de Miranda (2008) no Português do Brasil, que teve como objetivo investigar a hipótese do resumptivo como estratégia de último recurso. A hipótese subjacente é que o resumptivo é uma estratégia do formulador sintático frente à dificuldade no processamento online. Para isso, empregou a técnica de produção induzida a partir de preâmbulo. A tarefa dos participantes consistia em retomar a informação apresentada por estímulo sonoro após a pergunta. Primeiramente, o participante ouvia uma voz masculina (voz do João) que introduzia o tópico da sentença ou elemento envolvido no evento a ser relatado. Em seguida, aparecia na tela - por um tempo de $5000 \mathrm{~ms}$ - a informação que João havia transmitido. Após a mensagem sumir da tela, uma voz feminina perguntava “ O que João contou? ”. A tarefa do participante era, então, responder a essa pergunta, retomando a informação apresentada na tela. Veja abaixo um exemplo apresentado pela autora (MIRANDA, p. 136, 2005):

Voz do João: Vou contar algo sobre a enfermeira de um senhor velho.

Sentença na tela: A enfermeira de quem o senhor depende trocou o remédio do coração.

Voz feminina: $O$ que o João contou?

As variáveis independentes foram foco (sujeito, objeto direto, objeto indireto e genitivo) e encaixamento (sujeito e objeto direto) e a dependente foi o total de orações relativas resumptivas com mesmo foco e encaixamento da sentença apresentada na tela. As oito condições experimentais testadas foram:

SS - foco e encaixe no sujeito: $O$ rapaz que ajudou a deficiente perdeu o notebook no aeroporto;

SOD - foco no objeto direto e encaixe no sujeito: A aeromoça que o passageiro importunava derrubou a bandeja no chão;

SOI - foco no objeto indireto e encaixe no sujeito: A enfermeira de quem o idoso depende trocou o remédio do coração;

SGEN - foco no genitivo e encaixe no sujeito: $O$ aluno cujo pai ofendeu a professora saiu da escola essa semana; 
OS - foco no sujeito e encaixe no objeto direto: O jogador de futebol abraçou a fã que gritou durante todo o treino;

OOD - foco e encaixe no objeto direto: A enfermeira pesou o bebê que a pediatra atendeu ontem no berçário;

OOI- foco no objeto indireto e encaixe no objeto direto: $O$ chefe demitiu $o$ rapaz de quem a mulher reclamou ontem na oficina;

OGEN - foco no genitivo e encaixe no objeto direto: A milionária destratou o empregado cujo filho estava esperando na cozinha.

Na criação dos estímulos, foram controlados animacidade (+ANIMADO, +HUMANO), número (SINGULAR), gênero dos referentes (alternância entre feminino e masculino) e número de sílabas.

A partir da hipótese de trabalho e da hierarquia da acessibilidade (KEENAN e COMRIE, 1977), a autora prevê maior ocorrência de resumptivos nas estruturas de complemento de preposição (OI e GEN) por gerarem mais custos de processamento.

Das sentenças produzidas, 29 continham o pronome resumptivo, das quais 24 , correspondentes a $3,41 \%$ do total, apresentavam mesmo foco e encaixamento da sentença original apresentada. Somente essas foram analisadas pela autora.

Conforme esperado, houve efeito de encaixamento $(\mathrm{p}=.01)$, com as relativas de encaixe de objeto sendo mais produzidas que as de sujeito: médias de respostas 0,24 x 0,03 , respectivamente. As médias obtidas $(0,24$ para as de objeto e 0,03 para as de sujeito) sugerem que a ramificação à direita é mais propícia à ocorrência de pronome resumptivo.

Além disso, verificou-se efeito de foco $(\mathrm{p}=.02)$, com a direção das médias indicando maior ocorrência de resumptivos nas posições preposicionadas de OI $(0,25)$ e GEN $(0,23)$, seguidas das de OD $(0,05)$ e SUJ $(0,02)$. Ainda, houve interação entre as variáveis foco e encaixamento $(\mathrm{p}=.01)$, com as seguintes médias: SS - 0,05; SGEN - 0, 09; OOD - 0,09; OOI - 0,5; OGEN - 0,36. Para as condições SOD, SOI e OS não houve produção de resumptivos.

Assim, os resultados obtidos dão suporte à hipótese de que os resumptivos são empregados como estratégias de último recurso em contextos sintáticos de difícil processamento, como nas funções preposicionadas. 
Comparando a frequência de ocorrência dos resumptivos no trabalho de Miranda em PB e de Ferreira e Swets para o Inglês, percebe-se que a ocorrência foi muito menor em $\mathrm{PB}$, ou seja, a estratégia resumptiva não parece ser a preferida pelos falantes brasileiros. Além da diferença de língua, essa discrepância pode ter ocorrido em virtude de os resumptivos em Inglês estarem inseridos em ilhas sintáticas, que favorecem a ocorrência desses elementos, bem como por diferenças metodológicas quanto à técnica empregada para eliciação da estrutura. Além desses fatores, em Inglês, na posição de objeto, há apenas a estratégia de pronome pleno. Em PB, há a possibilidade de essa posição ser preenchida tanto pelo pronome pleno, que é uma forma estigmatizada, quanto pelo pronome nulo (cf. capítulo 3).

Com vistas a testar em que medida os custos de processamento relacionados à geração de estruturas complexas podem ser minimizados pelo uso de estratégias mais econômicas, como, por exemplo, a produção de passivas de sujeito em vez de relativas de objeto direto e cortadoras, e resumptivas em vez de relativas preposicionadas e genitivas, Corrêa et al (2018) conduziram um experimento de produção eliciada. O estudo partiu da hipótese de que o uso de estratégias de minimização de custo está atrelado às demandas impostas pelas condições de produção como a possibilidade (ou não) de planejamento da fala.

Eram apresentados, na tela do computador, um prêambulo46 a ser lido em voz alta, juntamente com duas imagens, na qual uma correspondia ao referente do DP a ser produzido:

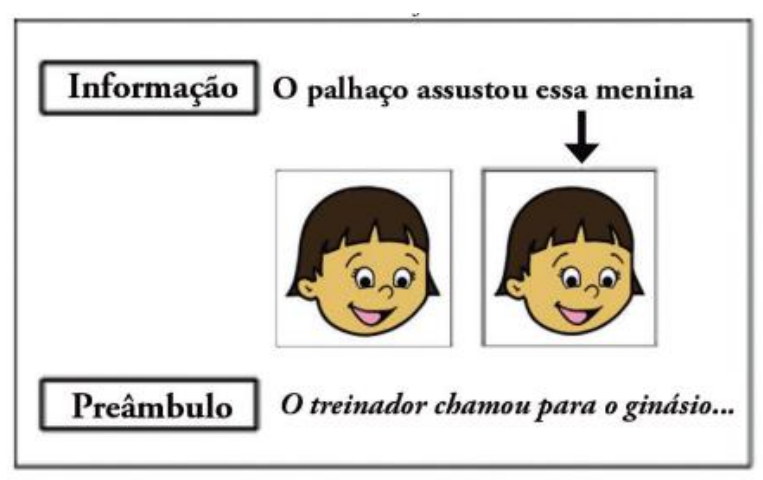

Figura 2: Imagem usada no experimento de Corrêa et al. (2018)

A ideia era que o participante desse continuasse ao preâmbulo, produzindo um DP que fizesse referência a uma das figuras. Nas condições de teste, esse DP

46 Exemplo de preâmbulo utilizado: O treinador chamou para o ginásio... 
deveria ser modificado por uma oração relativa restritiva e, nas distratoras, por um adjetivo ou PP.

$\mathrm{Na}$ condição planejada, o falante sabia previamente a qual dos referentes deveria fazer referência, enquanto que, na não planejada, o falante dá início à leitura do preâmbulo sem saber qual será o referente. As variáveis independentes foram demanda de processamento (alta, em situação de não planejamento; e baixa, quando planejada) e tipo de relativa (OD, OI com preposição funcional, OI com preposição lexical e Genitivo). O número de respostas padrão foi tomado como variável dependente.

As autoras previram que, em condições de baixa demanda, a produção de estruturas padrão seria maior, enquanto que a produção de estruturas minimizadoras seria mais esperada em situações de pouco planejamento, sendo mais comum em posições menos acessíveis, de acordo com a hierarquia da acessibilidade.

Os resultados foram na direção esperada, com as sentenças padrão sendo mais produzidas em condições de baixa demanda. Porém, nas relativas de objeto direto e de genitivo, não houve efeito desse fator. As relativas de genitivo foram pouco produzidas em ambas as condições de produção. No caso das relativas de objeto direto, houve, na condição de alta demanda, considerável variedade de respostas, as quais corresponderam a mais da metade do total de sentenças produzidas. Resultado semelhante foi obtido também por Grolla e Augusto (2016), em estudo conduzido no PB com crianças de 4 e de 5 anos, em uma tarefa que visava eliciar relativas de objeto direto, como por exemplo "A melancia que a Magali tá comendo/cortando". As autoras partiram da hipótese de que relativas de objeto direto, por serem de difícil processamento, dado efeitos de intervenção, são evitadas e substituídas por outras estratégias. Os resultados indicam que de fato crianças e adultos (grupo controle) se esquivam da produção de relativas de objeto, preferindo utilizar outros tipos de estruturas, como relativas de sujeito ("A melancia que tá cortada"), voz passiva (“A melancia que está sendo comida/cortada") ${ }_{47}$, no caso principalmente de adultos, e construções absolutivas ("A melancia que tá comendo/cortando"), nas crianças de 4 e 5 anos. A ocorrência de resumptivos foi muito baixa em todos os grupos, correspondendo, na produção de crianças de 4 e 5

47 Houve uma pequena ocorrência de passivas entre crianças de 5 anos, mas não em crianças de 4 anos. 
anos a $6,25 \%$ e $7,5 \%$, respectivamente, e de apenas $1,25 \%$ entre os adultos, sendo, portanto, uma estratégia bastante evitada.

Para as funções de OI e de Gen, as relativas resumptivas ocorreram em menor número em relação às outras estruturas produzidas, o que evidencia, de acordo com as autoras, que os pronomes resumptivos são estratégias de último recurso.

Grolla e Augusto (2014) conduziram experimentos, com crianças e adultos (grupo controle), para avaliar especificamente a produção de resumptivos em diferentes posições sintáticas- sujeito, objeto direto e genitivo - e a compreensão de estruturas de tópico-comentário48.

As autoras eliciaram a produção de relativas resumptivas de sujeito, objeto direto e genitivo. $\mathrm{Na}$ tarefa, eram apresentadas duas figuras que apresentavam um mesmo personagem em duas atividades distintas. Após uma breve descrição de cada uma pelo experimentador, o participante deveria colar um adesivo na figura escolhida e, ainda, contar a um fantoche de olhos vendados qual foi a escolha.

A maior ocorrência de orações relativas foi verificada na posição de sujeito, seguida da de objeto direto e de genitivo cortadora, em ambos os grupos. Houve diferença significativa entre adultos e crianças na produção de relativas genitivas e de objeto, de forma que essas foram de uso menos expressivo que nos adultos.

$\mathrm{Na}$ direção dos resultados de Miranda (2005), houve maior ocorrência de resumptivos em contextos de maior complexidade estrutural (relativas de genitivo, $42,1 \%$ ), demonstrando que, em PB, os pronomes resumptivos não são amplamente usados, sendo empregados como estratégias para facilitar a produção de uma sentença mais complexa. A posição de sujeito foi a que apresentou menor percentual de resumptivos, correspondendo a apenas $1,28 \%$ do total.

$\mathrm{Na}$ última atividade experimental, as autoras avaliaram o efeito de facilitação na compreensão de pronomes resumptivos inseridos em estruturas de tópicocomentário de objeto direto49. Para isso, utilizaram a técnica de julgamento de valorverdade a partir de histórias e imagens, em que os participantes deveriam julgar as proposições como verdadeiras ou falsas. As variáveis independentes foram faixa

\footnotetext{
48 Embora o foco das autoras seja na aquisição da linguagem, adultos foram testados como grupocontrole e os resultados encontrados fornecem discussões interessantes sobre o desempenho desses dois grupos frente ao emprego dos pronomes resumptivos, motivo pelo qual reportamos esta pesquisa aqui.

49 Exemplo de sentença utilizada: A cobra, a galinha foi pentear ela.
} 
etária (crianças de 3 e 4 anos) e adultos (grupo-controle) e tipo de sentença (com ou sem pronomes resumptivos).

$\mathrm{Na}$ tarefa, histórias eram contadas no computador e o participante deveria, ao final, confirmar a um fantoche se o que ela disse sobre a história havia acontecido ou não.

Os dados obtidos revelaram que os pronomes resumptivos não influenciaram no comportamento dos participantes em estruturas topicalizadas. Assim, se na compreensão não parecem atuar como elementos facilitadores, na produção, ao contrário, os pronomes resumptivos estão relacionados a demandas de processamento impostas por estruturas mais complexas de serem produzidas.

Os resultados obtidos no estudo de compreensão, porém, não nos permite tecer generalizações sobre o papel dos resumptivos durante o parsing, isto porque foi analisada somente a posição sintática de objeto direto em estrutura de tópico, em que o antecedente do pronome está em evidência, altamente acessível ao parser, o que pode justificar os resultados. A fim de se buscar evidências mais contundentes, é necessário investigar os pronomes resumptivos em outras posições sintáticas e ainda em estruturas que não envolvam topicalização, já que essa parece dispensar a utilização de um pronome resumptivo por já tornar proeminente o seu antecedente. Dessa forma, esta tese pretende contribuir para essa discussão, apresentando, no próximo capítulo, resultados experimentais.

Em estudo mais recente, Rangel (2017) eliciou a produção de relativas de objeto direto e preposicionado por crianças com idades entre 4 e 6 anos e adultos, com o objetivo de verificar quais configurações de animacidade do sujeito da relativa (elemento interveniente) e do núcleo relativizado conduzem à maior dificuldade para as relativas de objeto. Na tarefa, eram apresentadas na tela do computador duas figuras que se diferenciavam somente pela ação desempenhada pelos personagens, seguidas de uma contextualização das cenas feita pelo pesquisador. O participante deveria escolher uma das figuras após ser indagado pelo pesquisador. Foram apresentados 24 pares de figuras para eliciar 12 relativas de objeto direto e 12 de objeto preposicionado. Intercalado entre os pares de figura havia a eliciação de uma sentença distratora, que correspondia a uma relativa de sujeito.

O teste foi feito com 20 adultos e 90 crianças distribuídas em três faixas de idade: 4,5 e 6 anos. 
As variáveis independentes foram o traço de animacidade do núcleo relativizado e do sujeito da oração relativa e a posição sintática dentro da relativa: objeto direto ou preposicionado. A variável dependente foi a quantidade de estrutura produzida. Exemplos dos materiais utilizados no experimento:

\section{Objeto direto (sujeito e núcleo relativizado [+animado]):}

Pesquisador: "Nessa figura, a menina está empurrando o cachorro e nessa figura a menina está abraçando o cachorro. Qual cachorro você escolhe?" Participante: “... o cachorro que a menina está empurrando/abraçando”.

\section{Objeto preposicionado (sujeito e núcleo relativizado [+animado]):}

Pesquisador: "A menina colocou o chapéu no menino e a menina tirou o chapéu do menino. Qual menino você escolhe?"

Participante: “... o menino em quem a menina colocou o chapéu / de quem a menina tirou o chapéu”.

Compatível com outros estudos reportados (GROLLA e AUGUSTO, 2016; CORRÊA et al., 2018), foi verificado que estratégias de esquiva foram amplamente usadas por todos os grupos50: aos 4 anos a porcentagem é 74,7\%; aos 5 anos de $58,6 \%$; aos $668,9 \%$ e na fase adulta $63,3 \%$.

Quanto à produção da estrutura alvo, isto é, de relativas de objeto direto, observa-se que a frequência aumenta de acordo com a idade. Dessa forma, crianças de 4 anos são as que menos produzem, seguidas das de 5 e 6 anos e, então, dos adultos, que apresentam uma frequência de produção de relativas de objeto direto correspondente a $98,9 \%$.

Em relação à produção de relativas resumptivas, foi verificado que sua ocorrência se torna menos frequente de acordo com a idade. A produção de relativas de objeto direto com resumptivos por crianças de 4 anos $(12,1 \%)$ é quase 2 vezes maior em relação aos grupos de 5 e 6 anos ( $6 \%$ e 5,4\%, nesta ordem). Na fala dos adultos, o emprego de resumptivos é ainda menor, correspondendo a 1,1\%.

Em relação às relativas de objeto preposicionado, os dados revelaram que adultos e crianças preteriram o uso da estratégia envolvendo um sintagma preposicionado, utilizando, em vez dessas, várias outras estruturas (que corresponderam a $62,5 \%$ para os adultos e em torno de $74,3 \%$ para as crianças). A 
ocorrência de relativas resumptivas foi uniformemente baixa tanto na produção de crianças, quanto na de adultos, mas foi ainda menor neste último grupo, correspondendo a apenas $2,2 \%$ das ocorrências. Já as cortadoras aparecem em número maior na fala dos adultos $(77,8 \%)$ em relação aos três grupos de crianças (em média 63,96\%). Esses resultados comungam da ideia de que relativas preposicionadas são custosas e complexas, sendo substituídas por outras alternativas na língua. Além disso, a comparação entre as estratégias não-padrão mostrou que as cortadoras são preferidas em relação às resumptivas, sugerindo que essas são mais custosas.

No que concerne ao fator animacidade para relativas de objeto direto, resultados indicaram maior dificuldade de produção quando apresentam um sujeito inanimado e núcleo relativizado animado ("a cachorra que o aspirador limpou"). Isso se deve pelo fato de essa posição sintática ser comumente preenchida por argumento animado. A utilização de outras estratégias de esquiva mostra que a animacidade é fator determinante para facilitar ou dificultar a produção de relativas de objeto direto.

Para as relativas preposicionadas, todas as configurações de animacidade foram difíceis para os participantes o que mostra que essas estruturas são difíceis para a produção.

Com relação ao uso de resumptivos, para os dois tipos de relativas, os dados apontam para uma maior ocorrência desses elementos quando o núcleo relativizado é [+ animado] ("o menino que a onda só molhou ele"; "a menina que o computador toou música pra ela).

Em um trabalho semelhante, mas para o Português Europeu, Costa et al. (2015) eliciaram a produção de orações relativas de sujeito, de objeto direto (referida como relativas de objeto DP pelos autores) e de objeto preposicionado (relativas de objeto PP) em 20 participantes por meio da tarefa de preferência. Cada participante ouvia 24 histórias curtas, sendo 6 com eliciação de sujeito, 6 de objeto DP e 12 de PP. As perguntas que eliciavam as relativas de sujeito descreviam 2 pessoas desempenhando 2 ações - ou 2 verbos diferentes ou 1 objeto do mesmo verbo. As perguntas de objeto - OD e PP - tinham 2 pessoas que eram tema de uma ação feita por 2 pessoas diferentes ou 2 ações diferentes desempenhadas pela mesma pessoa, sendo 2 verbos que tem um complemento DP, ou verbos que tem um PP. A eliciação era garantida pela exigência de que o participante respondesse 
a cada questão começando com "Eu preferia ser...", ou "O homem...". Exemplo de eliciação de relativa de objeto PP usada no experimento foi:

Há dois homens. Uma borboleta toca aquele homem e um mosquito toca aquele homem. Que homem você preferia ser?

Resposta-alvo: Eu preferia ser o homem que a borboleta toca.

Os resultados obtidos mostram que para a posição de sujeito, a produção de relativas foi de 100\%, confirmando a hipótese de Keenan e Comrie (1977) que coloca a posição de sujeito como a favorita à relativização. A produção de relativa de objeto DP correspondeu a 26,8\% das ocorrências. Nesse caso, a estratégia de relativização foi substituída por outras, como relativas de sujeito com passiva (47\%). Esse resultado está compatível com os achados de Correa et al. (2018) para o Português do Brasil. Quase 30\% das estruturas produzidas na condição de objeto PP corresponderam à estratégia resumptiva $(29,9 \%)$, contra $12,3 \%$ na posição de objeto DP, resultado também parecido com o PB. A omissão da preposição, correspondente à estratégia cortadora, foi bastante alta, correspondendo a 73,4\%. Em conjunto, esses dados mostram que a estratégia padrão parece estar perdendo para formas alternativas, que se mostram mais econômicas ao processador. Nas relativas preposicionadas, a omissão da preposição parece ser a estrutura preferida, seguida da resumptiva. Já nas relativas de objeto DP, também são preferidas outras alternativas, seja a relativa de sujeito apassivada, ou também, a resumptiva.

No capítulo seguinte, buscamos avançar nessas discussões ainda em aberto, conduzindo uma série de experimentos que buscam elucidar questões referentes ao papel exercido pelo pronome resumptivo no processamento da sentença.

\subsubsection{3}

\section{A hipótese da acessibilidade do antecedente}

Tratando especificamente do processamento de orações relativas, Ariel (1999) desenvolve o princípio da acessibilidade para explicar a manifestação de pronomes resumptivos na compreensão/ produção.

A autora parte do estudo seminal de Keenan e Comrie (1977), que propõe uma hierarquia da acessibilidade do NP, capaz de determinar as possibilidades de relativização nas línguas, e associa a estratégia de relativização adotada ao princípio 
da acessibilidade. De acordo com esse princípio, antecedente acessíveis são retomados por lacunas. Ao contrário, com antecedentes pouco salientes, a retomada é preferivelmente feita via o pronome resumptivo.

O grau de acessibilidade é definido levando-se em consideração a conjugação de múltiplos fatores, que irão influenciar e determinar o aparecimento de um pronome resumptivo ou lacuna. Alguns desses fatores já foram testados experimentalmente e estão apresentados na seção anterior. São eles:

(i) Cruzamento de ilhas sintáticas: grau de acessibilidade do NP diminui.

(ii) Tipo de relativa: nas restritivas, a oração principal e a relativa estão conectadas de forma dependente, coesa para a recuperação da entidade à qual se referem. Nessas, portanto, o antecedente está altamente acessível. Nas explicativas, ao contrário, há independência entre as orações (marcada por pausa), o que torna o antecedente pouco acessível e favorece a ocorrência de um pronome resumptivo.

(iii) Tamanho do antecedente: quanto maior for o antecedente, em termos da quantidade de palavras de conteúdo que compõem o antecedente, maior a probabilidade de ocorrência de um pronome resumptivo $(55,65 \%)$. Por outro lado, quando o antecedente tem apenas uma ou duas palavras de conteúdo, a ocorrência de lacunas é preferida em quase $90 \%$ dos casos. Apesar dessa diferença entre lacunas e resumptivos, a autora salienta que os outros $45 \%$ dos antecedentes apresentam lacuna, indicando que esse fator complexidade não é forte o bastante para determinar a distribuição de resumptivos e lacunas.

(iv) Distância: quanto maior a distância entre o NP relativizado e a posição de origem desse NP, menor sua acessibilidade.

(v) Obrigatoriedade de argumento do NP relativizado: quando o argumento interno do verbo é obrigatório, ele é saliente e a representação do NP relativizado é acessada pela lacuna. Quando, porém, o argumento é opcional, a acessibilidade diminui e o PR auxilia na recuperação da informação.

(vi) Definitude do NP: NPs definidos são antecedentes acessíveis e, portanto, a recuperação via resumptivos não seria necessária. Ao contrário, NPs indefinidos introduzem entidades novas, com baixo grau de acessibilidade, o que favoreceria a ocorrência de pronomes resumptivos.

A hipótese levantada por Ariel busca determinar, do ponto de vista do processamento, fatores que favorecem (ou não) a ocorrência de resumptivos. 
A maior aceitabilidade de pronomes resumptivos em contextos mais complexos, determinado em termos de distância entre lacuna/pronome e antecedente, e posição sintática, por exemplo, pode ser explicada, por essa hipótese, em termos da maior ou menor saliência do núcleo relativizado. Essa hipótese será melhor detalhada no capítulo seguinte, quando reportaremos uma série de experimentos conduzidos.

\section{2.}

\section{Custos associados ao processamento de relativas resumptivas}

No capítulo 3, apresentamos alguns fatores que tornam a derivação de estruturas relativas complexas. Foi ressaltado que mesmo a ocorrência de um pronome resumptivo apresenta um custo, o qual estaria manifesto nas interfaces. Derivação envolvendo essa estratégia ocorrem mediante situações específicas, como contextos de ilhas sintáticas, efeitos de intervenção e encalhamento de preposições, por exemplo. Dessa forma, embora seja licenciado com mais liberdade em PB, a inserção de pronome resumptivo é considerada como sendo uma estratégia de último recurso. Aqui, iremos nos concentrar naqueles fatores que parecem impor uma sobrecarga ao processamento dessas estruturas. Valeremo-nos, para tanto, das contribuições trazidas pela vasta literatura reportada nas seções anteriores.

O custo de processamento envolvido na compreensão de uma oração relativa está atrelado à resolução da dependência entre lacuna (gap) e antecedente (filler). Admite-se que há uma preferência do processador linguístico por uma dependência formada com lacuna (FRAZIER, 1989; HAWKINS,1999; ALEXPOULOU e KELLER, 2007; HAN et al., 2012).

Durante o parsing, o antecedente deve ser mantido na memória de trabalho até que a lacuna seja encontrada e a vinculação entre eles seja estabelecida, o que gera um custo de memória. O custo oriundo da resolução dessa dependência, no entanto, pode ser relativizado, a depender de alguns aspectos, conforme veremos a seguir.

Diferentes estudos experimentais mostram que a distância linear entre elementos de uma dependência, por exemplo, no caso entre lacuna e antecedente, interfere no processamento, isto porque, quanto maior for essa distância, maior parece ser o custo de armazenamento e de integração (GIBSON, 2000;2005). Neste caso, há mais material linguístico interveniente, o que torna o antecedente (filler da 
dependência) menos acessível ao parser (ARIEL,1999). Há ainda o custo relativo à distância estrutural entre antecedente e elemento anafórico (HOFMEISTER e NORCLIFFE, 2013), de modo que com o aumento da distância, o resumptivo torna o processamento mais rápido. A natureza do material interveniente também é questão importante para o custo de processamento. Estudos de Warren e Gibson (1999) e Gordon et al. (2001) indicam que o custo de processamento de uma oração relativa pode ser influenciado pelo tipo de antecedente utilizado (pronome, expressão referencial ou nome próprio). Nesses contextos, os pronomes resumptivos parecem facilitar a compreensão, na medida em que explicitam morfologicamente as marcas da lacuna, facilitando, assim, a referência com o seu antecedente. Trabalhos experimentais como o de Hofmeister e Norcliffe (2013) e de Alexpoulou e Keller (2003) apresentam evidências quanto a esse papel facilitador dos pronomes resumptivos.

Ainda relacionado à acessibilidade do antecedente, está a posição sintática de extração, ou seja, a posição original de movimento. Inúmeros trabalhos mostram, como visto nas seções anteriores, que relativas de sujeito são mais fáceis de serem processadas, seja pela proximidade entre elementos da dependência, seja pela posição saliente do antecedente. Ao contrário, em posição de objeto (direto ou indireto), por exemplo, em que há efeito de intervenção (FRIEDMAN et al., 2004) e, portanto, maior custo de armazenamento, o custo de processamento é maior.

Parece razoável supor que, nesses contextos mais complexos, que exigem mais do parser, estratégias alternativas, como pronomes resumptivos tornem a identificação do antecedente mais fácil.

No entanto, considerando que a análise inicial do parser é pela dependência formada com lacuna, a realização de um resumptivo quebra a expectativa e um processo de reanálise deve ser feito, o que também acarreta em custo (HAWKINS, 1999), já que o processador deve retomar a sentença para solucionar a referência. Esse custo de reanálise pode ser compensado em contextos de maior complexidade, em que a presença do pronome resumptivo pode vir a facilitar a recuperação do antecedente da relativa.

Dessa forma, é possível observar um descompasso nas implicações de custo da inserção de resumptivos no que tange ao modo como é caracterizado pela Teoria Gerativa - o processo de computação sintática - e ao modo como se dá o processamento online, conforme investigado pela Psicolinguística. Do ponto de 
vista da teoria linguística, a inserção de um pronome resumptivo implica alto custo relacionado à manifestação morfofonológica e semântica de traços do antecedente nas interfaces, sendo, por isso, pior avaliados que a forma padrão por adultos falantes do Português do Brasil (conforme será visto no experimento 1 no próximo capítulo). Já para o processamento, esses elementos atuam de forma a reduzir os custos associados à manutenção dos nomes na memória de trabalho e sua posterior integração à estrutura.

No próximo capítulo, reportaremos uma série de experimentos que buscam investigar os custos envolvidos na compreensão de orações relativas, a partir do contraste entre relativas com resumptivas vs cortadoras e/ou padrão. 


\section{Experimentos}

Neste capítulo, apresentamos o conjunto de quatro atividades experimentais realizada por nós: dois experimentos de julgamento de aceitabilidade e dois de escuta automonitorada51.

Os experimentos de julgamento de aceitabilidade 52 visam a verificar como os falantes do PB avaliam a presença de pronomes resumptivos inseridos em diferentes posições sintáticas no contexto de sentenças relativas, as quais apresentam diferentes graus de complexidade em termos derivacionais e também de processamento. Buscase, examinar, se há uma preferência pelo resumptivo em posições sintáticas mais baixas (genitivo, objeto indireto e oblíquo), conforme proposto por Tarallo (1983) com base na hierarquia de acessibilidade defendida por Keenan e Comrie (1977), e também como a estratégia resumptiva é avaliada em relação a outras estratégias de relativização possíveis no $\mathrm{PB}$ - a estratégia padrão e a estratégia cortadora.

Os dois experimentos de escuta automonitorada foram concebidos com vistas a verificar a influência do fator distância linear no processamento de orações relativas resumptivas, em comparação com as estratégias padrão (experimento 3) e cortadora (experimento 4). No experimento 3, contrastamos relativas padrão e resumptivas nas posições de sujeito e objeto direto inseridas em distâncias curtas, médias e longas. No experimento 4, trabalhamos com relativas cortadoras e resumptivas em posição de oblíquo e de genitivo, mantendo as três medidas de distância usadas no experimento 3.

Também busca-se investigar, a partir desse conjunto de experimentos, o efeito da presença de um elemento interveniente (uma expressão referencial - DP) entre o antecedente e a posição sintática de origem, fator que vem sendo considerado tanto no âmbito da teoria gerativa - hipótese da intervenção (FRIEDMANN, BELLETTI e RIZZI, 2009)- como nos estudos em processamento, com destaque para a Teoria da Localidade da Dependência - Dependency Locality Theory (GIBSON, 1998;

\footnotetext{
51 A pesquisa foi submetida e teve parecer favorável pelo Comitê de Ética da PUC-Rio (Anexo I). 52 Utilizamos o termo aceitabilidade e não gramaticalidade seguindo Schutze e Sprouse (2014, p. 2), os quais argumentam que a gramática é um constructo mental não acessível à consciência, de modo a não ser possível para o falante ter impressões sobre a gramaticalidade de uma sentença. $\mathrm{O}$ julgamento de aceitabilidade, ao contrário, envolve a percepção espontânea em resposta a um estímulo, avaliando em que medida determinada sentença é boa ou ruim.
} 
2000; WARREN e GIBSON, 1999) e para a hipótese da interferência baseada em similaridade de traços - Similarity-based interference hypothesis (GORDON, HENDRICK e JOHNSON, 2001). Nesse contexto, avalia-se o papel do pronome resumptivo ( $v s$ lacunas) na recuperação do antecedente, tendo em vista tanto aspectos relativos a custo computacional quanto a custo de manutenção do antecedente na memória de trabalho, como discutido por Ariel (1999).

\section{1}

\section{Experimento 1: julgamento de aceitabilidade}

Este experimento teve como objetivo investigar (i) como falantes do PB avaliam a estratégia de relativização resumptiva em contraste com a estratégia padrão e (ii) se há uma preferência pelo pronome resumptivo em posições mais baixas na estrutura, conforme proposto por Tarallo (1983), a partir da hierarquia de acessibilidade de Keenan e Comrie (1977). Explora-se, portanto, efeito de um DP interventor no contraste entre relativas de sujeito e demais tipos de relativas.

As variáveis independentes foram (i) tipo de relativa (padrão e resumptiva) e (ii) posição sintática do elemento anafórico (sujeito, objeto direto, objeto preposicionado53 e genitivo).

A variável dependente foi o valor atribuído à sentença em uma escala Likert de 5 pontos, em que 0 correspondia a sentenças não aceitas na língua e 4, plenamente aceitas.

O tipo de relativa (padrão vs. resumptiva) foi tomado como fator grupal e a posição sintática como fator intra-sujeito, em um design $2 \times 4$, totalizando 8 condições experimentais, ilustradas na tabela a seguir:

\footnotetext{
53 Estamos usando a nomenclatura objeto preposicionado para designar os complementos verbais encabeçados por preposição. Todos os verbos utilizados são, de acordo com o dicionário Aurélio, transitivos diretos e indiretos.
} 


\begin{tabular}{|c|c|c|}
\hline & Padrão & Resumptivas \\
\hline & $\begin{array}{l}\text { O porteiro que salvou uma } \\
\text { menina ganhou uma recompensa. }\end{array}$ & $\begin{array}{l}\text { O porteiro que ele salvou uma } \\
\text { menina ganhou uma recompensa. }\end{array}$ \\
\hline \multicolumn{3}{|l|}{ Sujeito (Suj) } \\
\hline & $\begin{array}{l}\text { A médica indicou o psicólogo que } \\
\text { estudou na melhor universidade do } \\
\text { país. }\end{array}$ & $\begin{array}{l}\text { A médica indicou o psicólogo que } \\
\text { ele estudou na melhor } \\
\text { universidade do país. }\end{array}$ \\
\hline \multirow{3}{*}{ Objeto Direto (OD) } & $\begin{array}{l}\text { A funcionária que o supervisor } \\
\text { elogiou ganhou um aumento. }\end{array}$ & $\begin{array}{l}\text { A funcionária que o supervisor } \\
\text { elogiou ele ganhou um aumento. }\end{array}$ \\
\hline & & \\
\hline & $\begin{array}{l}\text { O advogado defendeu a garota } \\
\text { que o vizinho acusou de roubo. }\end{array}$ & $\begin{array}{l}\text { O advogado defendeu a garota } \\
\text { que o vizinho acusou ela de } \\
\text { roubo. }\end{array}$ \\
\hline \multirow{3}{*}{ Objeto Preposicionado (OPrep) } & $\begin{array}{l}\text { O menino pro qual a enfermeira } \\
\text { deu o antibiótico errado foi pro } \\
\text { CTI ontem. }\end{array}$ & $\begin{array}{l}\text { O menino que a enfermeira deu } \\
\text { pra ele o antibiótico errado foi pro } \\
\text { CTI ontem. }\end{array}$ \\
\hline & $\begin{array}{l}\text { A advogada interrogou o menino } \\
\text { pro qual a empresária doou grande } \\
\text { quantia de dinheiro. }\end{array}$ & $\begin{array}{l}\text { A advogada interrogou o menino } \\
\text { que a empresária doou pra ele } \\
\text { grande quantia de dinheiro. }\end{array}$ \\
\hline & $\begin{array}{l}\text { A jogadora cujo empresário } \\
\text { desapareceu abandonou a carreira. }\end{array}$ & $\begin{array}{l}\text { A jogadora que o empresário dela } \\
\text { desapareceu abandonou a carreira. }\end{array}$ \\
\hline \multicolumn{3}{|l|}{ Genitivo (Gen) } \\
\hline & $\begin{array}{l}\text { O médico demitiu a secretária que } \\
\text { cujo primo agrediu um paciente. }\end{array}$ & $\begin{array}{l}\text { O médico demitiu a secretária que } \\
\text { o primo dela agrediu um paciente. }\end{array}$ \\
\hline
\end{tabular}

Tabela 4: Exemplos de estímulos usados por condição experimental - experimento 1

5.1.1

Método

Participantes

192 adultos realizaram o teste de julgamento de aceitabilidade, sendo 102 no grupo padrão e 90 no grupo de resumptivas. Desse total, contudo, 60 de cada grupo concluíram a tarefa com êxito e foram contabilizados para análise. Conforme será descrito em Procedimento, o teste foi realizado em uma plataforma online, sendo registrado o horário de início e término da pesquisa e a média de tempo demandado (em torno de 20 minutos). Assim, excluímos participantes que desviaram desse tempo para menos (10 minutos) ou para mais (acima de 40 minutos). Na tabela a seguir apresentamos os dados do perfil dos participantes: 


\begin{tabular}{cll}
\hline \multirow{2}{*}{ Sexo } & \multicolumn{1}{c}{ Padrão } & \multicolumn{1}{c}{ Resumptivas } \\
& Feminino: 35 & Feminino: 40 \\
Entre 21 e 35 anos: 28 & Entre 21 e 35 anos: 31 \\
& Entre 36 e 50: 15 & Entre 36 e 50: 13 \\
& Acima de 51: 14 & Acima de 51: 9 \\
& Abaixo dos 20: 4 & Abaixo dos 20: 7 \\
& Pós-graduação completa: 21 & Pós-graduação completa: 26 \\
& Pós-graduação incompleta: 2 & Pós-graduação incompleta: 9 \\
Escolaridade & Graduação completa: 17 & Graduação completa: 8 \\
& Graduação incompleta:17 & Graduação incompleta: 8 \\
& Ensino médio concluído: 3 & Ensino médio concluído: 3 \\
Naturalidade & Rio de Janeiro: 36 & Ensino médio incompleto: 6 \\
Domínio de & Inglês: 43 & Rio de Janeiro: 24 \\
outro idioma & Duas ou mais línguas: 19 & Minas Gerais: 24 \\
\hline
\end{tabular}

Tabela 5: Informação sobre o perfil dos participantes - experimento 1

\section{Material}

Para a condução do experimento foram utilizadas um total de 40 sentenças em cada grupo, sendo 16 experimentais (4 para cada condição) e 24 distratoras, formadas por sentenças que variavam quanto ao nível de aceitabilidade, ou seja, havia exemplares de estruturas em todos os pontos da escala, indo de pouco aceitáveis a muito aceitáveis54. As distratoras constituíam-se, por exemplo, por estruturas pouco aceitas, formadas com pronome cujo usados indevidamente, ambiguidade estrutural, verbos inergativos transitivos (ex. "correr/ emagrecer/ nadar alguém"), repetição do pronome "que" (o que que ...); e por estruturas mais aceitas, como orações encabeçadas com “que” em função de pronome interrogativo, complemetizador, etc.

$\mathrm{Na}$ criação dos estímulos experimentais, cuidamos para controlar fatores que poderiam comprometer o experimento. Todos as sentenças eram iniciadas por um DP formado por um determinante no singular e definido seguido de nomes biformes e com o traço [+ANIMADO]. A utilização de antecedentes do tipo [+ humano] deveu-se ao fato de estudos de corpora (TARALLO, 1983; MOLLICA, 1997; 2003) revelaram uma tendência de maior uso de pronomes resumptivos nessa condição.

${ }_{54} \mathrm{O}$ rol de sentenças distratoras utilizadas pode ser conferido no Anexo IV, juntamente com as sentenças experimentais. 
Além disso, cuidou-se para que metade dos estímulos iniciassem com um determinante no feminino e a outra metade no masculino ("o porteiro que ele salvou uma menina..."; “a aluna que ela denunciou o professor...”) e, ainda, que os nomes utilizados fossem de gêneros diferentes, de modo a não dificultar o estabelecimento da referência, visto que essa pista semântica não está sendo testada e poderia influenciar nos resultados (“o passageiro que a aeromoça conhecia ele...”; “a

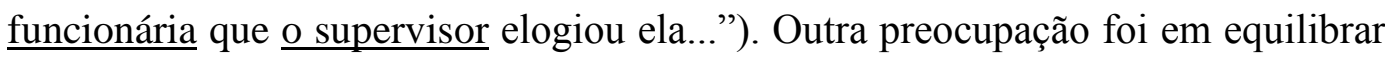
o encaixamento da relativa na oração principal, de modo que metade das sentenças de cada condição apresentava encaixe central e metade encaixe final. Por fim, procuramos criar sentenças factíveis e com palavras familiares aos participantes55.

Todos os estímulos foram apresentados por áudio e tratados no programa Audacity. Embora alguns trabalhos tenham mostrado que a forma de apresentação de estímulo não parece interferir no julgamento do falante (cf. capítulo 4), acreditamos, como Tarallo (1983), que, por ser a estratégia resumptiva uma estrutura informal e típica da fala espontânea, a escuta torna mais natural as estruturas investigadas.

\section{Procedimento}

O experimento foi programado em na plataforma Pesquisa Online56. A ideia de aplicar o experimento utilizando uma plataforma de pesquisa na web deu-se pela possibilidade de atingirmos um grande número de participantes e uma população heterogênea57, permitindo um maior alcance da pesquisa. Além disso, a plataforma utilizada apresenta facilidade de aplicação, tendo em vista que o participante pode responder à pesquisa através de diferentes aparelhos (celular, computador, tablete) e sem sair de casa.

Apesar de esse tipo de ferramenta não possibilitar o contato direto entre participante e pesquisador, impossibilitando o controle de fatores externos que possam a vir a interferir na atividade e de possibilitar que participante ouça ao áudio mais de uma vez, julgamos ser positiva a utilização de plataformas web por permitir

\footnotetext{
55 A lista completa dos estímulos usados encontra-se no Anexo IV. 56 Site da plataforma: www.onlinepesquisa.com

57 Apesar de o uso da plataforma online permitir o alcance de uma população heterogênea, nosso grupo de participantes apresentava uma certa homogeneidade possivelmente pelo fato de o convite ter sido feito via redes sociais e com isso ter alcançado pessoas de um círculo mais restrito.
} 
o acesso rápido e fácil a um vasto número de participantes, tornando mais robustos e significativos os resultados alcançados 58 .

O participante deveria acessar o link da pesquisa59 e ler as instruções apresentadas em duas telas (Anexo II), que continham, além de orientações para a realização da tarefa, informações sobre procedimentos éticos envolvidos na pesquisa.

A tarefa iniciava com a escuta de três sentenças-treino como forma de habituar o participante à tarefa. Em seguida, as sentenças-teste eram apresentadas de forma aleatória ao participante.

O participante deveria julgar a aceitabilidade de cada sentença ouvida, atribuindo as notas $0,1,2,3$ ou 4 , que correspondiam a uma gradação de aceitabilidade.

No final, havia um questionário sociolinguístico, que nos possibilitou traçar um perfil do participante, por meio de informações como idade, sexo, naturalidade, grau de escolaridade e conhecimento de língua estrangeira (Anexo III). Cabe destacar que essa pesquisa não tem como pretensão fazer uma análise de ordem sociolinguística desses dados, mas tão somente, rastrear, em linhas gerais, um perfil de participante.

\section{1 .2}

\section{Hipóteses e previsões}

Neste primeiro experimento optamos por contrastar apenas dois tipos de relativas: as relativas padrão e as relativas com resumptivos. A ideia era comparar duas estruturas que, em princípio, com base na revisão da literatura, seriam custosas tanto em termos de uma análise da derivação sintática quanto no que tange ao processamento.

A seguir, detalhamos, para as diferentes estruturas, nossas hipóteses e previsões, formuladas com base nos que foi desenvolvido nos capítulos 3 e 4 .

\section{Relativas preposicionadas e genitivas:}

58 Experimentos conduzidos via plataforma web (Amazon Mechanical Turkey - AMT) e através de softwares que captam medidas relativas aos tempos de reação apresentaram resultados semelhantes, mostrando a validade de se utilizar mecanismos alternativos às pesquisas tradicionais feitas em laboratório. (ENOCHSON, K.; CULBERTSON, J., 2014; SPROUSE, 2011)

${ }_{59}$ Cada lista correspondia a um link de acesso. 
No caso das relativas padrão preposicionadas, o custo derivacional é alto, pois, além do movimento do DP com traço QU-, também ocorre o deslocamento da preposição. Assim, considerando o princípio de economia que opera sobre Move, estabelecendo que o movimento deve conter o menor número possível de traços, nossa hipótese é que outras estratégias de relativização mais econômicas como a cortadora e a resumptiva serão preferidas. De acordo com a hipótese de antinaturalidade de pied-piping, proposta por Kenedy (2007), relativas de pied-piping são estruturas não naturais no PB. A exemplo do que o autor verificou em tarefa off-line de julgamento de gramaticalidade, é esperado que os participantes reconheçam essas relativas como parte de seus conhecimentos linguísticos, já que são construções ensinadas na escola, porém receberão julgamentos mais baixos que as alternativas não padrão, que fariam parte da competência linguística natural.

Nas genitivas padrão, o movimento deve cruzar o DP sujeito, tornando também sua derivação complexa. Portanto, também para esses casos, espera-se que as relativas padrão sejam evitadas, dando preferência para a relativas resumptivas ou as relativas cortadoras.

Dentre as duas alternativas não padrão, a cortadora será preferida por implicar menor custo nas interfaces, seguida das resumptivas (ver capítulo 3). No experimento 1 , avalia-se, no contraste com a padrão, apenas a estratégia resumptiva. Com base nas considerações de que as resumptivas implicam custo tanto em PF quanto em LF, espera-se uma atribuição de valores em faixas intermediárias, ou seja, não serão tidas como ótimas - dado que a língua tem uma alternativa mais econômica nas interfaces (a cortadora) - mas também não serão atribuídos valores muito baixos, visto que, sobrevivendo a preposição, o resumptivo é obrigatório.

Essa previsão também encontra sustentação na literatura em processamento. Embora em todas as preposicionadas e genitivas haja um DP sujeito interveniente, não há outro fator (distância linear, por exemplo) que, em princípio, dificulte/comprometa a recuperação do antecedente. Assim, também é esperado que sejam atribuídos valores intermediários na escala de aceitabilidade às resumptivas nessas posições.

\section{Relativas não preposicionadas de sujeito e de objeto:}

No caso da relativa de sujeito, conforme visto no capítulo 2, Grolla (2005a) considera agramaticais as relativas de sujeito com resumptivo. Segundo a autora, 
dado que nessas estruturas o movimento é curto, da posição de [spec, TP] para [spec, CP], o pronome não é necessário (ver capítulo 3). Argumenta ainda, com base na condição de restrição de sujeito mais alto, conforme proposta por McCloskey (2007), que o pronome não pode ocupar posição de sujeito que esteja subjacente ao elemento a que está ligado, por uma violação do princípio B. Assim, no caso das relativas de sujeito, apenas a relativa padrão estaria disponível. A despeito dessa restrição, contudo, não podemos desconsiderar o estudo de Lessade-Oliveira (2008), que incorpora dados de Tarallo (1983), estudo esse que mostra ter havido, ao longo do tempo, um incremento de resumptivos em relativas de sujeito, embora o número de resumptivas seja bastante reduzido. Algumas características do antecedente favoreceriam a ocorrência do resumptivo, com destaque para distância linear entre elementos correferentes (MOLLICA, 2003), fator esse que afetaria tanto indivíduos escolarizados quanto não escolarizados. Segundo a autora, esse incremento seria reflexo de uma mudança no sistema pronominal do $\mathrm{PB}$ caracterizado por um crescente preenchimento fonético do sujeito.

Tendo isso em vista, nossa hipótese é que as relativas de sujeito padrão, dentre os demais tipos de relativas, são as que apresentam menor custo computacional e receberão valores altos na escala de aceitabilidade. As relativas com resumptivo, por sua vez, deverão receber os valores mais baixos na escala de aceitabilidade. A mesma previsão se faz com base na literatura sobre processamento dado que o antecedente e o pronome estão bastante próximos, tanto em termos de distância hierárquica quanto linear. Ou seja, o antecedente está altamente acessível.

No caso das relativas de objeto, seguindo a literatura - tanto em teoria linguística quanto em psicolinguística -, nossa hipótese é que a presença de um DP sujeito interventor, com traços similares ao do DP antecedente, torna mais custoso o processamento das relativas de objeto. Logo, essas, assim como as preposicionadas, deverão receber valores na escala de acessibilidade menores do que as relativas de sujeito.

Quanto ao contraste entre relativa padrão e relativa com resumptivo pleno, nossa hipótese é que estas serão mais custosas do que aquelas, pois, independentemente da análise assumida para a padrão (movimento ou resumptivo nulo, cf. Grolla 2005b), a relativa com pronome realizado implica um custo tanto em LF quanto em PF, enquanto a padrão não terá custo em PF. Espera-se, portanto, 
que as relativas de objeto padrão recebam valores mais altos na escala do que as relativas com resumptivo.

\section{1 .3}

\section{Resultados}

Os resultados computados correspondem às avaliações dos participantes em uma escala graduada. Por se tratar de dados discretos, foram analisados por meio do teste qui-quadrado60, que analisa se a proporção de notas obtidas deveu-se à atuação das variáveis independentes. A seguir apresentamos uma tabela com os valores absolutos e percentuais dos julgamentos para cada item da escala, por condição experimental. Para facilitar a visualização de como as notas estão distribuídas em cada condição, incluímos o gráfico 1 .

\begin{tabular}{|c|c|c|c|c|c|c|c|c|}
\hline & PSuj & POD & PGen & POPrep & RSuj & ROD & RGen & ROPrep \\
\hline & 0 & 2 & & 12 & 16 & 11 & 22 & 23 \\
\hline $\mathbf{0}$ & $(0 \%)$ & $(0,83 \%)$ & $4(1,66 \%)$ & $(4,98 \%)$ & $(6,64 \%)$ & $(4,58 \%)$ & $(9,16 \%)$ & $(9,58 \%)$ \\
\hline & 0 & 4 & & & 93 & 34 & 10 & 10 \\
\hline 1 & $(0 \%)$ & $(1,66 \%)$ & $7(2,92 \%)$ & $7(2,92 \%)$ & $(38,75 \%)$ & $(14,16 \%)$ & $(4,16 \%)$ & $(4,16 \%)$ \\
\hline & 2 & 6 & & & 78 & 52 & 81 & 58 \\
\hline 2 & $(0,83 \%)$ & $(2,5 \%)$ & $9(3,75 \%)$ & $9(3,75)$ & $(32,5 \%)$ & $(21,66 \%)$ & $(33,75 \%)$ & $(24,16 \%)$ \\
\hline & 16 & 23 & 50 & 44 & 32 & 63 & 74 & 80 \\
\hline 3 & $(6,66 \%)$ & $(9,58 \%)$ & $(20,83 \%)$ & $(18,33 \%)$ & $(13,33 \%)$ & $(26,25 \%)$ & $(30,83 \%)$ & $(33,33 \%)$ \\
\hline & 222 & 205 & 170 & 168 & 21 & 80 & 53 & 69 \\
\hline 4 & $(92,5 \%)$ & $(85,41 \%)$ & $(70,83 \%)$ & $(70 \%)$ & $(8,75 \%)$ & $(33,33 \%)$ & $(22,08 \%)$ & $(28,75 \%)$ \\
\hline otal & $\begin{array}{c}240 \\
(100 \%)\end{array}$ & $\begin{array}{c}240 \\
(100 \%)\end{array}$ & 240 & 240 & 240 & $\begin{array}{c}240 \\
(100 \%)\end{array}$ & $\begin{array}{c}240 \\
(100 \%)\end{array}$ & 240 \\
\hline
\end{tabular}

Tabela 6: Quantidade de julgamentos por condição experimental - experimento 1

60 O software utilizado para essa análise foi o Action Stat, em sua versão demo, disponível no site: www.portalaction.com.br. 


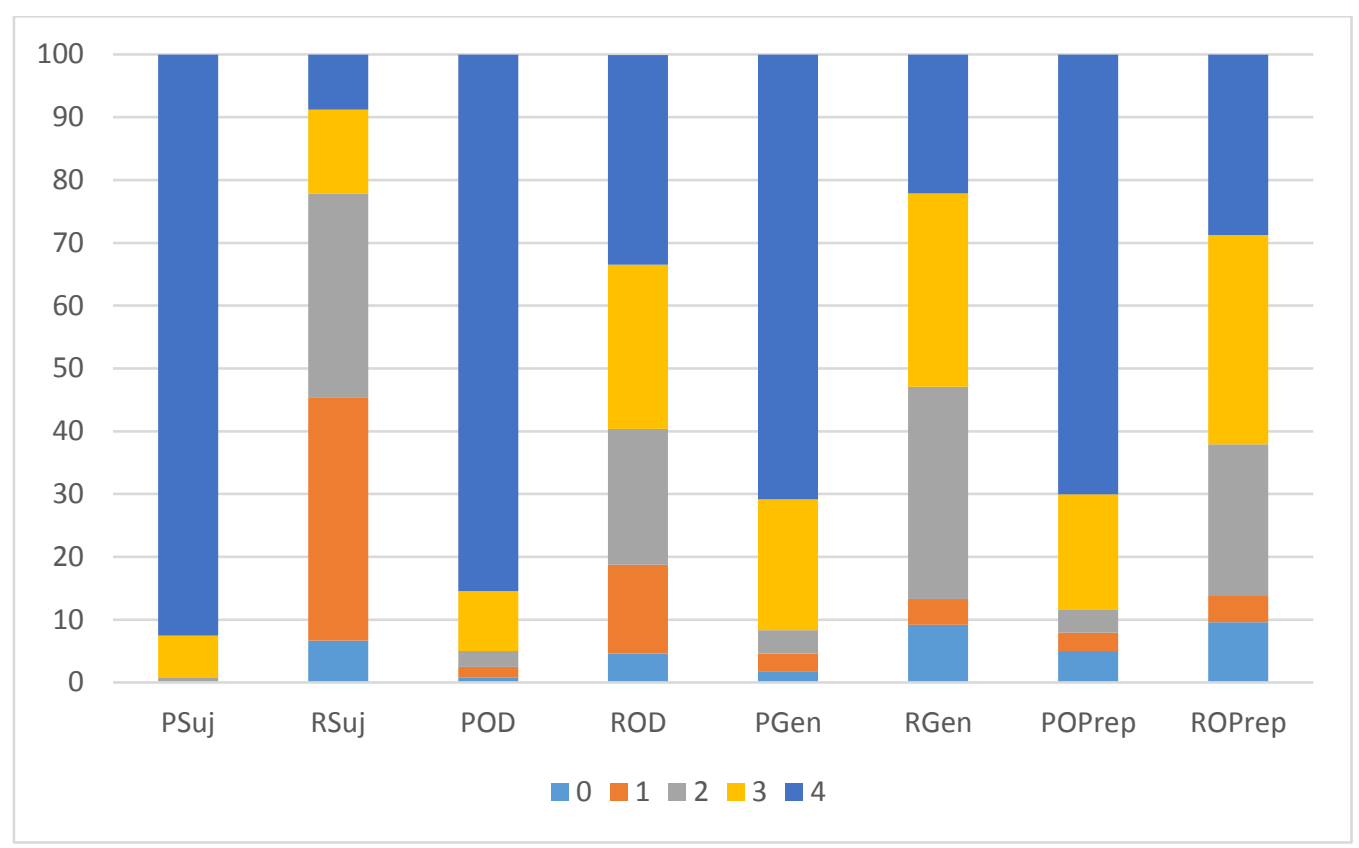

Gráfico 1: Valor percentual para cada nota por condição experimental - experimento 1

Dentre as relativas padrão, a maior aceitabilidade foi para a posição de sujeito, seguida da de objeto direto, e a menor para as de genitivo e objeto preposicionado. Em relação às resumptivas, a maior aceitabilidade ocorreu na condição envolvendo objeto direto, enquanto que a maior rejeição do pronome foi na posição de sujeito (considerando-se as notas 0 e 1 ).

A análise estatística para verificar se houve diferença entre as notas atribuídas dentro de cada condição indicou uma diferença significativa entre os julgamentos das condições PSuj (estatística de Pearson = 5; p= 0,02), POD (estatística de Pearson; $\mathrm{p}=$ 0,02 ) e PGen (estatística de Pearson; $\mathrm{p}=0,02$ ).

Em relação à influência das variáveis nos julgamentos, o teste qui-quadrado de homogeneidade, que avalia o efeito de cada variável separadamente, mostrou que as variáveis posição sintática e tipo de relativa influenciaram nas notas atribuídas. Os gráficosøa abaixo ilustram as proporções de notas em razão de cada variável.

${ }_{61}$ Os gráficos apresentados são gerados pelo programa Action Stat, utilizado para rodar os testes estatísticos de qui-quadrado. 


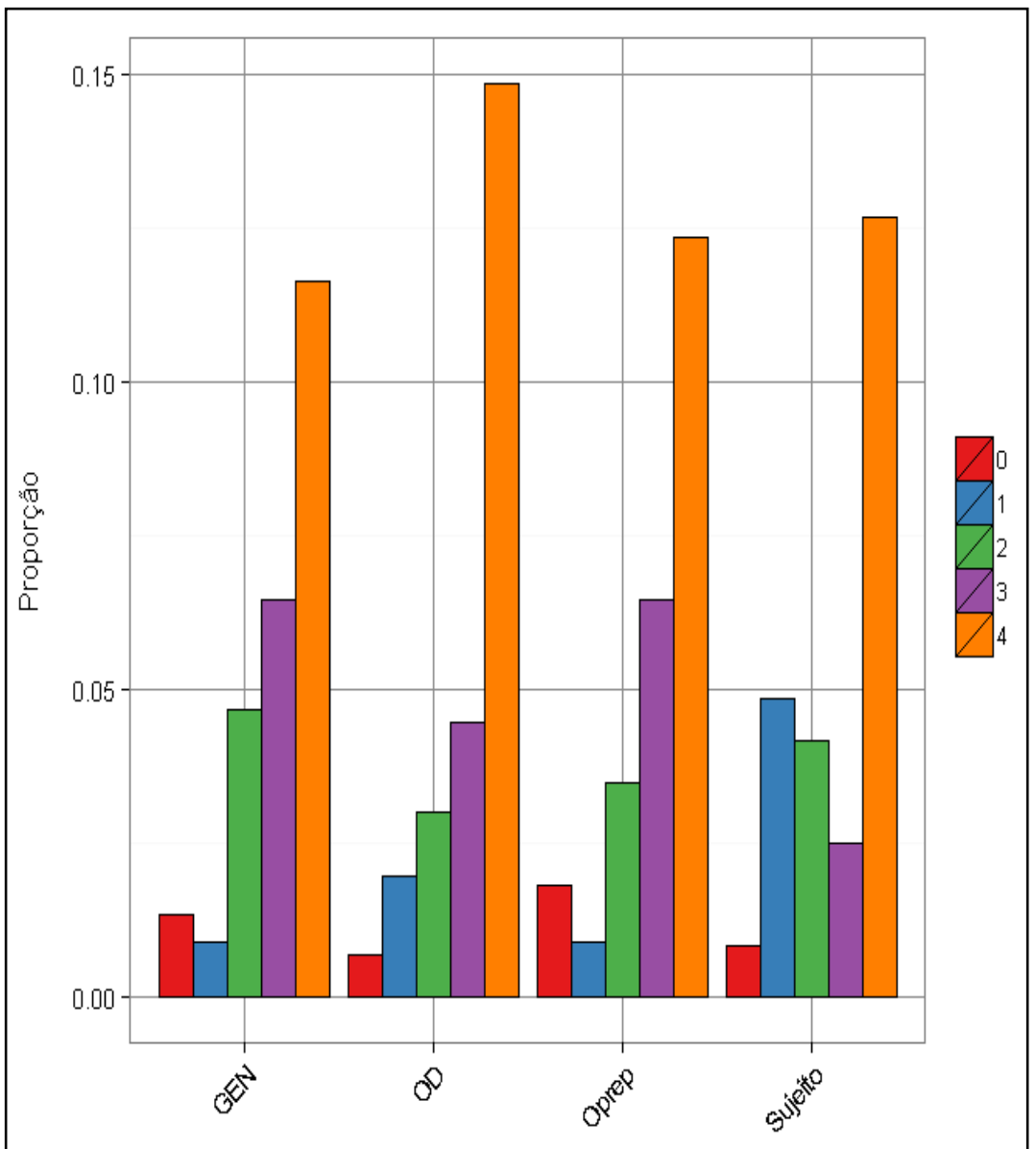

Gráfico 2: Proporção de notas por posição sintática - experimento 1

No gráfico 2 (proporção de notas por posição sintática), em que as duas estratégias de relativização estão consideradas em conjunto, apreende-se que a posição de objeto direto foi a mais aceita $\left(X^{2}=165,38 ; p=4,17 \mathrm{E}-29\right)$, resultado não esperado, mas que se explica pelo fato de essa posição ter recebido valores altos para a estratégia padrão ( $2^{\circ}$ mais aceito, após sujeito) e de os julgamentos terem se concentrado nas notas 2,3 e 4, para os resumptivos. 


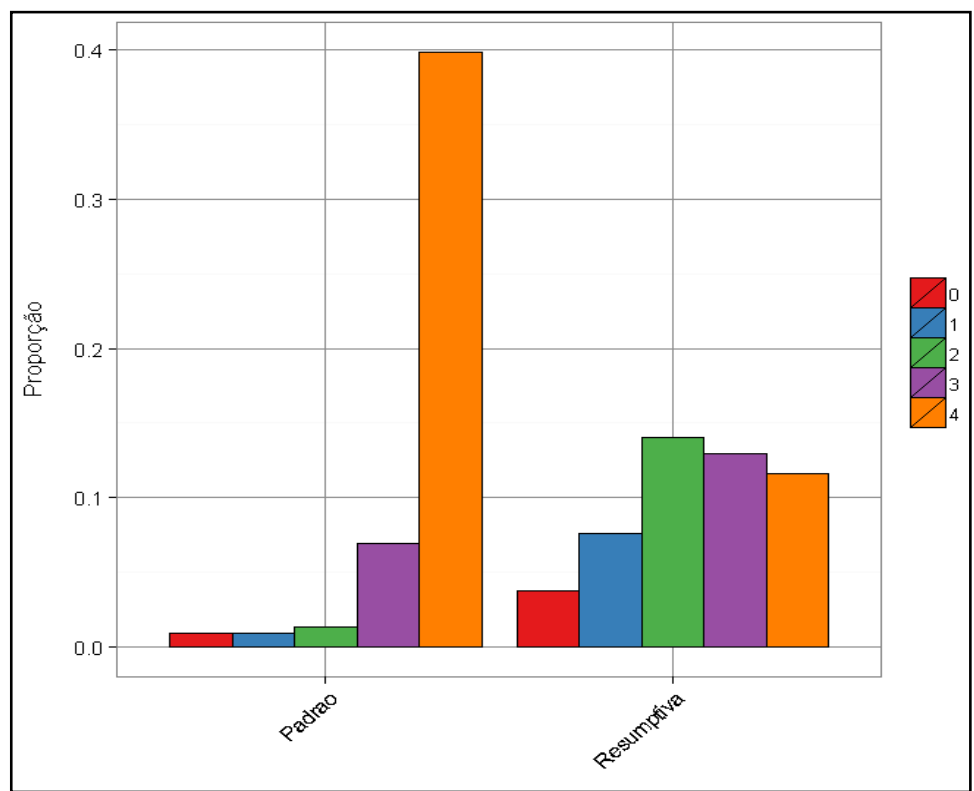

Gráfico 3: Proporção de notas por tipo de relativa testada - experimento 1

No gráfico 3 (proporção de notas por tipo de relativa), verifica-se que as relativas do tipo padrão foram, proporcionalmente, mais aceitas $\left(X^{2}=665,97 ; p=\right.$ $8,10025 \mathrm{E}-143)$ e seus julgamentos concentraram-se majoritariamente nos valores mais altos da escala (notas 3 e 4). Já as relativas resumptivas tiveram julgamentos mais diluídos e bem distribuídos ao longo da escala. Apesar dessa dispersão das notas pelos valores da escala, é possível notar que essas orações não são totalmente rejeitadas pelos participantes, tendo em vista que a maior parte das notas está no valor intermediário da escala (nota 2).

No que tange à interação entre essas duas variáveis, o resultado não foi significativo, indicando que os julgamentos obtidos não podem ser explicados pela conjugação dessas variáveis.

Por fim, procedemos ao contraste entre pares, comparando a diferença entre as condições. Para a estratégia padrão, houve diferença significativa entre todas as comparações envolvendo a posição de sujeito, tendo esta sido mais bem aceita que a de objeto direto $(Z=6,57 ; p=0,01)$, de objeto preposicionado $(Z=22,26 ; p=2,48$ E-06) e de genitivo ( $\mathrm{Z}=25,19 ; \mathrm{p}=5,18 \mathrm{E}-07)$. Houve também resultado significativo nos contrastes envolvendo objeto direto vs. objeto preposicionado $(Z=4,98 ; p=$ $0,02)$ e objeto direto vs. genitivo $(Z=6,51 ; p=0,01)$, com as de objeto direto sendo mais bem avaliadas.

Para as relativas resumptivas, só houve diferença significativa nos pares em que se contrastou o sujeito com outra posição sintática, com as de sujeito sendo, 
significativamente, pior avaliadas que as de objeto direto $(\mathrm{Z}=41,11 ; \mathrm{p}=1,43 \mathrm{E}-10)$, objeto preposicionado $(Z=38,35 ; p=5,91 \mathrm{E}-10)$ e genitivo $(Z=26,07 ; p=3,28 \mathrm{E}-07)$.

No que tange à comparação pareada entre padrão e resumptivas, todos os contrastes foram significativos, com a estratégia padrão tendo maior aceitação em relação à resumptiva. $\mathrm{Na}$ posição de sujeito, foram encontrados os valores estatísticos de $Z=274,97$ e $p=9,36 E-62$. Para a de objeto direto, $Z=90,80$ e $p=$ 1,58E-21, objeto preposicionado $\mathrm{Z}=60,82$ e $\mathrm{p}=6,25 \mathrm{E}-15$ e, finalmente, na de genitivo $\mathrm{Z}=72,70$ e $\mathrm{p}=1,50 \mathrm{E}-17$.

\section{1 .4}

\section{Discussão dos resultados}

Os resultados relativos à variável tipo de relativa indicaram uma preferência pela estratégia padrão em todas as posições testadas. Esse resultado está de acordo com os dados de julgamento de aceitabilidade obtidos por Tarallo (1983), descritos no capítulo 2 da presente tese. Em relação à posição de sujeito, nossas hipóteses foram confirmadas, já que a estratégia padrão foi altamente aceita, enquanto a resumptiva foi a mais rejeitada. Assim, no caso das relativas de sujeito, em que não há nenhum efeito de intervenção e o antecedente está bastante acessível, a forma padrão - envolvendo movimento curto - é a estratégia preferida. Cabe ressaltar que, em todos os estímulos, o antecedente da relativa era constituído por DPs definidos, característica que desfavorece, conforme mostram os trabalhos de Tarallo (1983); Mollica (1997); Kato e Nunes (2009)62 e Ariel (1999), a ocorrência de pronome resumptivo. Dessa forma, permanece como um desdobramento de pesquisa uma investigação sobre a avaliação dos pronomes resumptivos com DPs indefinidos como antecedentes.

Nas relativas de objeto direto, um cenário complexo emerge, pois tanto a estratégia padrão quanto a resumptiva têm implicações em termos de custo derivacional e de processamento, devido ao efeito de intervenção. Verifica-se uma alta aceitação das relativas de objeto padrão $(85,41 \%$, com nota 4$)$, ou seja, a

62 Nas palavras dos autores, "For unclear reasons, relative clauses involving an overt resumptive in the subject position is generally acceptable if the "head" of the relative is indefinite; if the head is definite, the resumptive pronoun cannot be subjacent to the relative pronoun." (KATO e NUNES, p. 92, 2009). 
despeito da presença de um elemento interventor, estas foram bem avaliadas. Houve, contudo, conforme esperado, diferença estatística significativa entre a padrão de objeto e a de sujeito. Em relação à estratégia resumptiva, apresentamos a hipótese de que esta seria mais custosa do que a padrão, pois, independentemente da análise assumida para a padrão (movimento ou resumptivo nulo, cf. Grolla 2005b), haveria na resumptiva custos associados à presença do pronome pleno tanto em LF quanto em PF. Embora, de fato, a estratégia padrão tenha sido, significativamente, mais aceita que a resumptiva, os julgamentos para as resumptivas distribuíram-se entre os pontos da escala 2,3 e 4, com pouca rejeição à presença do pronome $(18,74 \%$, somando-se notas 0 e 1$)$. Ou seja, a relativa com pronome não é tratada como agramatical, mas sua aceitabilidade não é plena63.

Em relação às posições mais baixas, era esperado, com base na hipótese da Anti-naturalidade do Pied-pipping (KENEDY, 2007; 2008), que as relativas padrão preposicionadas de pied-piping apresentassem valores mais baixos que as resumptivas na escala de aceitabilidade. Não foi isso, contudo, o que se verificou. Mesmo para as relativas padrão de genitivo, com o pronome "cujo", a aceitação foi da ordem de $90 \%$ se considerarmos notas $3(20,83 \%)$ e 4 (70,83\%). Para explicar a diferença entre nossos resultados e os de Kenedy, é importante observar, primeiramente, que os estímulos não foram apresentados auditivamente. Outra diferença é que os tipos de estímulos usados em nosso experimento e aqueles usados por Kenedy (que manipulou também a gramaticalidade das sentenças - ver capítulo 4), bem como a natureza da tarefa de cada experimento (julgamento rápido de aceitabilidade vs. julgamento de aceitabilidade sem pressão de tempo). Além disso, é importante considerar que o contraste verificado por Kenedy foi entre formas padrão e cortadoras, não havia presença de resumptivos nos estímulos. No experimento de escuta automonitorada, retomaremos este ponto.

Em relação às formas resumptivas, observamos um comportamento similar ao que havíamos registrado para as de objeto direto. Estatisticamente, a única diferença obtida foi no contraste entre essas posições e a posição de sujeito, em que, como vimos, a forma resumptiva foi rejeitada. Logo, embora haja um DP sujeito

${ }_{63}$ Em desdobramento a este trabalho, pretende-se examinar o comportamento individual dos participantes em relação às resumptivas de objeto, no sentido de avaliar se a distribuição dos julgamentos na escala reflete efetivamente um comportamento do grupo. 
interveniente e, portanto, a acessibilidade do antecedente possa estar em certa medida afetada, como a distância é curta, o pronome resumptivo não é crucial para a correferência nesse caso, ficando os valores situados no plano intermediário da escala de aceitabilidade.

Considerando a literatura linguística (capítulo 3) e psicolinguística (capítulo 4), que convergem para a ideia de que a estratégia cortadora é a alternativa mais econômica e, portanto, mais aceita, em relação à padrão e resumptiva, aplicamos um segundo experimento que pretende contrastar essas três estratégias. Como apenas formas preposicionadas permitem uma avaliação das três estratégias, não incluímos as relativas de sujeito e de objeto. Para que pudéssemos ter um total não muito grande de itens experimentais por participante visto que projetamos um design within, optamos no experimento 2 por examinar apenas dois tipos de relativas preposicionadas: de genitivo e de oblíquo, esta última não testada no experimento 1 .

\section{2}

\section{Experimento 2: julgamento de aceitabilidade}

No presente experimento foram manipuladas as seguintes variáveis independentes: (i) tipo de relativa (padrão, cortadora e resumptiva) e (ii) posição sintática (oblíquo e genitivo).

A variável dependente foi o valor atribuído à sentença em escala Likert de 5 pontos, em que zero correspondia a sentenças não aceitas na língua e quatro plenamente aceitas. O desenho experimental foi do tipo within com design fatorial (3x2). Os estímulos foram organizados em três listas, por meio do quadrado latino.

As condições experimentais resultantes da combinação dos níveis das variáveis independentes estão representadas na tabela abaixo. Na tabela também, colocamos exemplos de sentenças com encaixe central e final, um fator controlado no experimento. 


\begin{tabular}{|c|c|c|c|}
\hline & Padrão & Cortadora & Resumptiva \\
\hline G & $\begin{array}{l}\text { A jogadora cujo } \\
\text { empresário desapareceu } \\
\text { abandonou a carreira. }\end{array}$ & $\begin{array}{l}\text { A jogadora que o } \\
\text { empresário desapareceu } \\
\text { abandonou a carreira. }\end{array}$ & $\begin{array}{l}\text { A jogadora que o } \\
\text { empresário dela } \\
\text { desapareceu abandonou a } \\
\text { carreira. }\end{array}$ \\
\hline \multirow{2}{*}{ Oblíquo } & $\begin{array}{l}\text { A diretora premiou o } \\
\text { professor cuja aluna } \\
\text { ganhou } \\
\text { competição. } \\
\text { A funcionária com quem } \\
\text { o diretor simpatiza } \\
\text { ganhou uma promoção. }\end{array}$ & $\begin{array}{l}\text { A diretora premiou o } \\
\text { professor que a aluna } \\
\text { ganhou } \\
\text { competição. } \\
\text { A funcionária que o } \\
\text { diretor simpatiza ganhou } \\
\text { uma promoção. }\end{array}$ & $\begin{array}{l}\text { A diretora premiou o } \\
\text { professor que a aluna dele } \\
\text { ganhou uma competição. } \\
\text { A funcionária que o diretor } \\
\text { simpatiza com ela ganhou } \\
\text { uma promoção. }\end{array}$ \\
\hline & $\begin{array}{l}\text { O reitor acusou a } \\
\text { professora com quem o } \\
\text { inspetor brigou na } \\
\text { semana passada. }\end{array}$ & $\begin{array}{l}\text { O reitor acusou a } \\
\text { professora que } \\
\text { inspetor brigou na } \\
\text { semana passada. }\end{array}$ & $\begin{array}{l}\text { O reitor acusou a } \\
\text { professora que o inspetor } \\
\text { brigou com ela na semana } \\
\text { passada. }\end{array}$ \\
\hline
\end{tabular}

Tabela 7: Exemplos de estímulos usados por condição experimental - experimento 2

\subsubsection{Método}

\section{Material}

Foram criadas 36 sentenças experimentais (6 sentenças por condição) e 36 distratoras (Anexo IV). As sentenças foram organizadas em formato de quadrado latino (Anexo V), conforme já mencionado.

Em relação às distratoras, metade era agramatical e a outra metade, gramatical. As gramaticais foram construídas utilizando o "que" em contextos diferentes ao examinados neste trabalho. Já as agramaticais abarcaram construções envolvendo a variante europeia do Português, casos de ambiguidade, preposições desgarradas, pronome "cujo" indevidamente usado, duplicação do "que" e outras envolvendo alternância transitiva/inergativa.

A fim de garantir cadência e prosódia próximas de um contexto natural de fala, assim como no experimento 1, gravamos as sentenças e tratamos o áudio com o programa Audacity, que nos permitiu equalizar os tons de voz, reduzir ruídos e cortar os estímulos.

Foi mantido o controle de todos os fatores descritos no primeiro experimento e também a forma de apresentação dos estímulos. 
Participantes

129 adultos acessaram o experimento na plataforma online, mas desse total, apenas 72 concluíram a tarefa e foram contabilizados para análise, sendo 24 em cada uma das 3 listas. A participação por lista foi totalmente aleatória.

A tabela abaixo apresenta os dados relacionados ao perfil dos participantes:

\begin{tabular}{|c|c|c|c|}
\hline & Lista 1 & Lista 2 & Lista 3 \\
\hline Sexo & Feminino: 20 & Feminino: 20 & Feminino: 19 \\
\hline Naturalidade & $\begin{array}{l}\text { Entre } 21 \text { e } 35 \text { anos: } 16 \\
\text { Entre } 36 \text { e } 50: 2 \\
\text { Acima de } 51: 2 \\
\text { Abaixo de } 20: 4 \\
\text { Rio de Janeiro: } 16\end{array}$ & $\begin{array}{l}\text { Entre } 21 \text { e } 35 \text { anos: } 13 \\
\text { Entre } 36 \text { e } 50: 5 \\
\text { Acima de } 51: 2 \\
\text { Abaixo de } 20: 4 \\
\text { Rio de Janeiro: } 14\end{array}$ & $\begin{array}{l}\text { Entre } 21 \text { e } 35 \text { anos: } 15 \\
\text { Entre } 36 \text { e 50: } 2 \\
\text { Acima de 51: } 2 \\
\text { Abaixo de 20: } 5 \\
\text { Rio de Janeiro: } 15\end{array}$ \\
\hline Escolaridade & $\begin{array}{l}\text { Graduação } \\
\text { incompleta: } 12 \\
\text { Graduação completa: } \\
6 \\
\text { Pós-graduação } \\
\text { completa: } 4 \\
\text { Ensino } \\
\text { completo: } 2\end{array}$ & $\begin{array}{l}\text { Graduação incompleta: } \\
11 \\
\text { Graduação completa: } 2 \\
\text { Pós-graduação } \\
\text { incompleta: } 3 \\
\text { Pós-graduação } \\
\text { completa: } 3 \\
\text { Ensino } \\
\text { incompleto: } 1 \quad \text { Médio } \\
\text { Ensino } \\
\text { completo: } 4 \quad \text { Médio }\end{array}$ & $\begin{array}{l}\text { Graduação incompleta: } \\
10 \\
\text { Graduação completa: } 8 \\
\text { Pós-graduação } \\
\text { completa: } 3 \\
\text { Ensino } \\
\text { completo: } 3\end{array}$ \\
\hline $\begin{array}{l}\text { Domínio de } \\
\text { outro idioma }\end{array}$ & $\begin{array}{l}\text { Inglês: } 22 \\
\text { Duas ou mais línguas: } \\
8\end{array}$ & $\begin{array}{l}\text { Inglês: } 21 \\
\text { Duas ou mais línguas: } 6\end{array}$ & $\begin{array}{l}\text { Inglês: } 20 \\
\text { Duas ou mais línguas: } 7\end{array}$ \\
\hline
\end{tabular}

Tabela 8: Informações sobre o perfil dos participantes - experimento 2

Procedimento

O procedimento adotado foi o mesmo do experimento1.

\section{2 .2}

\section{Hipóteses e previsões}

Dentre as três estratégias de relativização, a cortadora é considerada a mais produtiva nas posições preposicionadas e de genitivo, de acordo com estudos de corpora (TARALLO, 1988; LESSA-DE-OLIVEIRA, 2009). Conforme visto no capítulo 3, a estratégia cortadora seria a mais econômica, por envolver movimento 
apenas do elemento QU- e apagamento em PF. Sendo assim, é esperado que essa seja mais aceita que a resumptiva e a padrão.

Em relação à posição sintática, tanto na posição de oblíquo (39a) quanto na de genitivo (39b) há elemento interveniente entre o nome relativizado e o pronome resumptivo. Embora a posição de genitivo envolva, conforme visto no capítulo 3, efeito de ilha (left branch extraction), nos estímulos usados no presente experimento, a posição de genitivo ocorre no interior do sujeito da relativa e, nesse sentido, há menos nódulos intervenientes linearmente e estruturalmente entre o antecedente e lacuna/pronome resumptivo. Assim, quanto à recuperação de informação na memória, o antecedente, em termos de distância linear, está mais acessível na relativa de genitivo do que na relativa de oblíquo. Logo, a previsão é que a aceitabilidade de pronome resumptivo será maior na condição oblíquo do que na de genitivo.

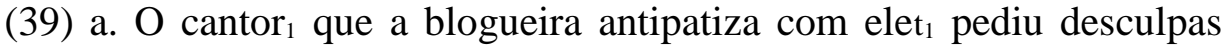
publicamente. (Oblíquo central)

$\mathrm{O}$ reitor defendeu a professora ${ }_{1}$ que $\mathrm{o}$ inspetor brigou com elat ${ }_{1}$ semana passada. (Oblíquo final)

b. A noiva ${ }_{1}$ que o fotógrafo delat ${ }_{1}$ desmarcou o ensaio cancelou o contrato. (Genitivo central)

$\mathrm{O}$ torcedor ofendeu a jogadora ${ }_{1}$ que o técnico dela $\mathrm{t}_{1}$ invadiu o campo na hora do gol. (Genitivo final)

\section{2 .3}

\section{Resultados}

Os julgamentos obtidos para cada condição experimental estão dispostos na tabela abaixo e no gráfico 4 a seguir:

\begin{tabular}{ccccccc}
\hline & Padrão & Padrão & Cortadora & Cortadora & Resumptiva & Resumptiva \\
Oblíquo & Genitivo & Oblíquo & Genitivo & $\begin{array}{c}\text { Oblíquo } \\
\text { Genitiva }\end{array}$ & 58 \\
0 & 4 & 24 & 50 & 74 & 41 & $(13,42 \%)$ \\
& $(0,92 \%)$ & $(5,55 \%)$ & $(11,57 \%)$ & $(17,13 \%)$ & $(9,49 \%)$ & 85 \\
& 10 & 15 & 55 & 75 & 105 & $(19,67 \%)$ \\
\hline
\end{tabular}




\begin{tabular}{ccccccc}
\hline & 19 & 37 & 75 & 84 & 86 & 102 \\
2 & $(4,39 \%)$ & $(8,56 \%)$ & $(17,36 \%)$ & $(19,44 \%)$ & $(19,90 \%)$ & $(23,61 \%)$ \\
& 59 & 71 & 115 & 88 & 85 & 88 \\
3 & $(13,65 \%)$ & $(16,44)$ & $(26,62 \%)$ & $(20,37 \%)$ & $(19,67 \%)$ & $(20,37 \%)$ \\
& 340 & 285 & 137 & 111 & 115 & 99 \\
4 & $(78,70 \%)$ & $(65,97 \%)$ & $(31,71 \%)$ & $(25,69 \%)$ & $(26,62 \%)$ & $(22,91 \%)$ \\
\hline
\end{tabular}

Tabela 9: Quantidade de julgamentos por condição experimental - experimento 2

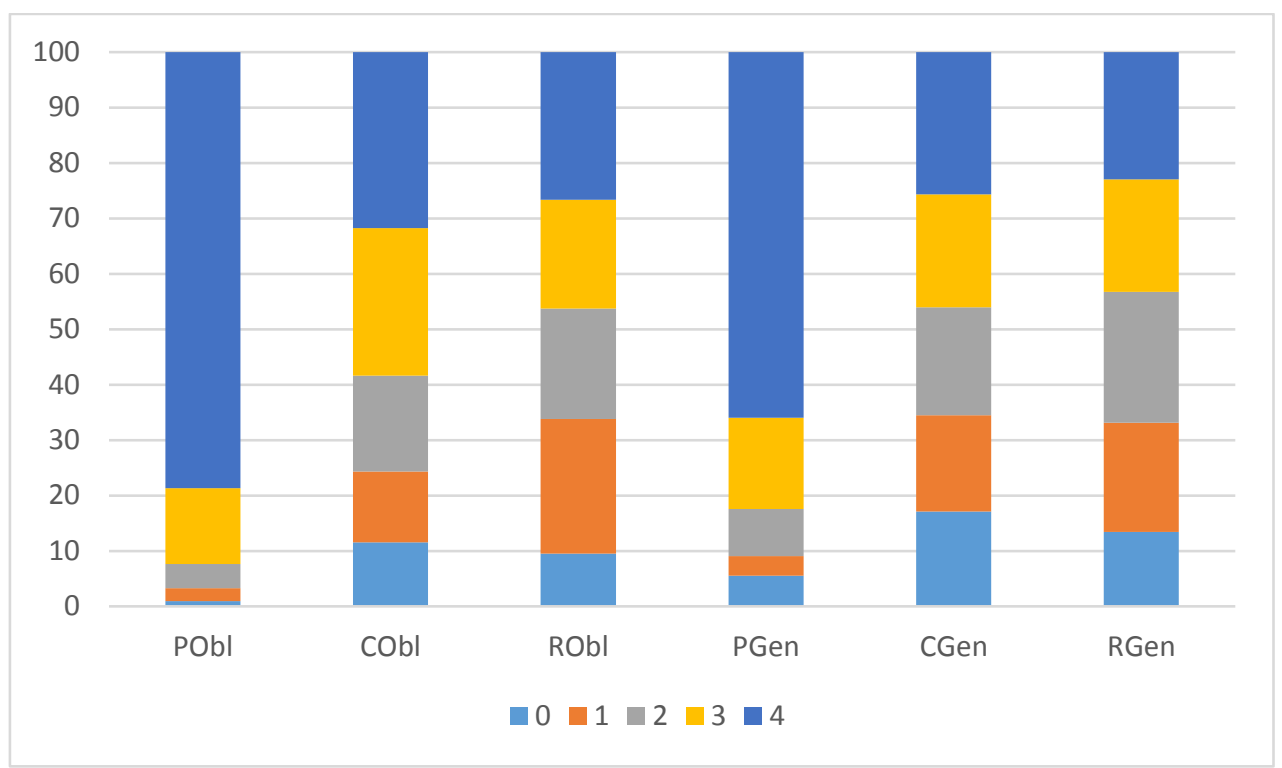

Gráfico 4: Valor percentual para cada nota por condição experimental - experimento 2

A variável posição sintática teve efeito significativo $(\mathrm{X}: 28,42 ; \mathrm{p}=0,00001)$, com as relativas de oblíquo recebendo notas maiores, conforme verificado no gráfico 5 a seguir:

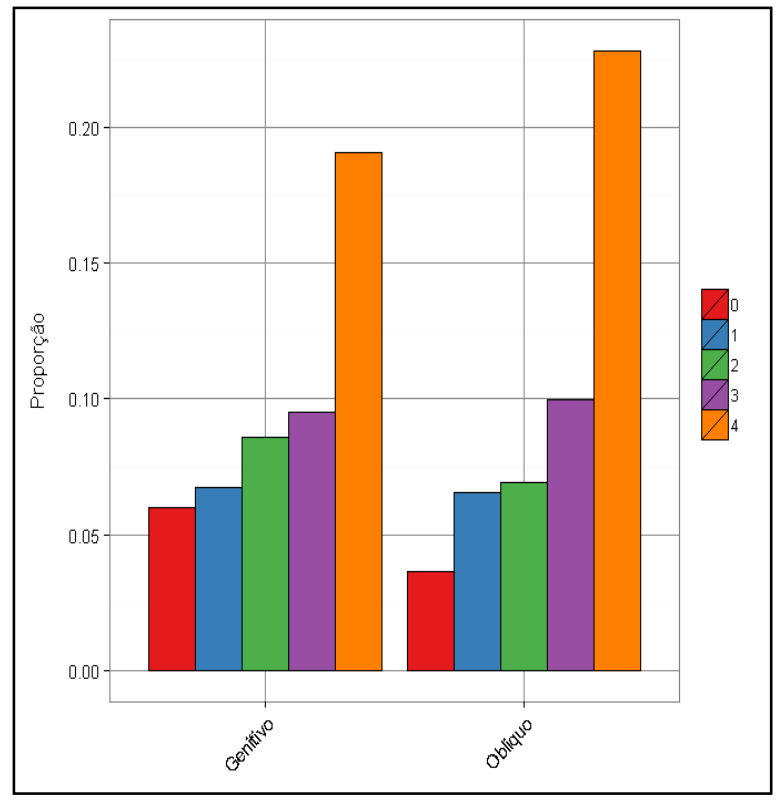

Gráfico 5: Proporção de notas por posição sintática - experimento 2 
Verificou-se também resultado significativo para a variável tipo de relativa, com as relativas padrão tendo sido mais aceitas do que as cortadoras e resumptivas, conforme ilustrado no gráfico 6 a seguir. Os valores obtidos por meio do teste de qui-quadrado foram: $\mathrm{X}=: 555,42 ; \mathrm{p}=8,87 \mathrm{E}-115$.

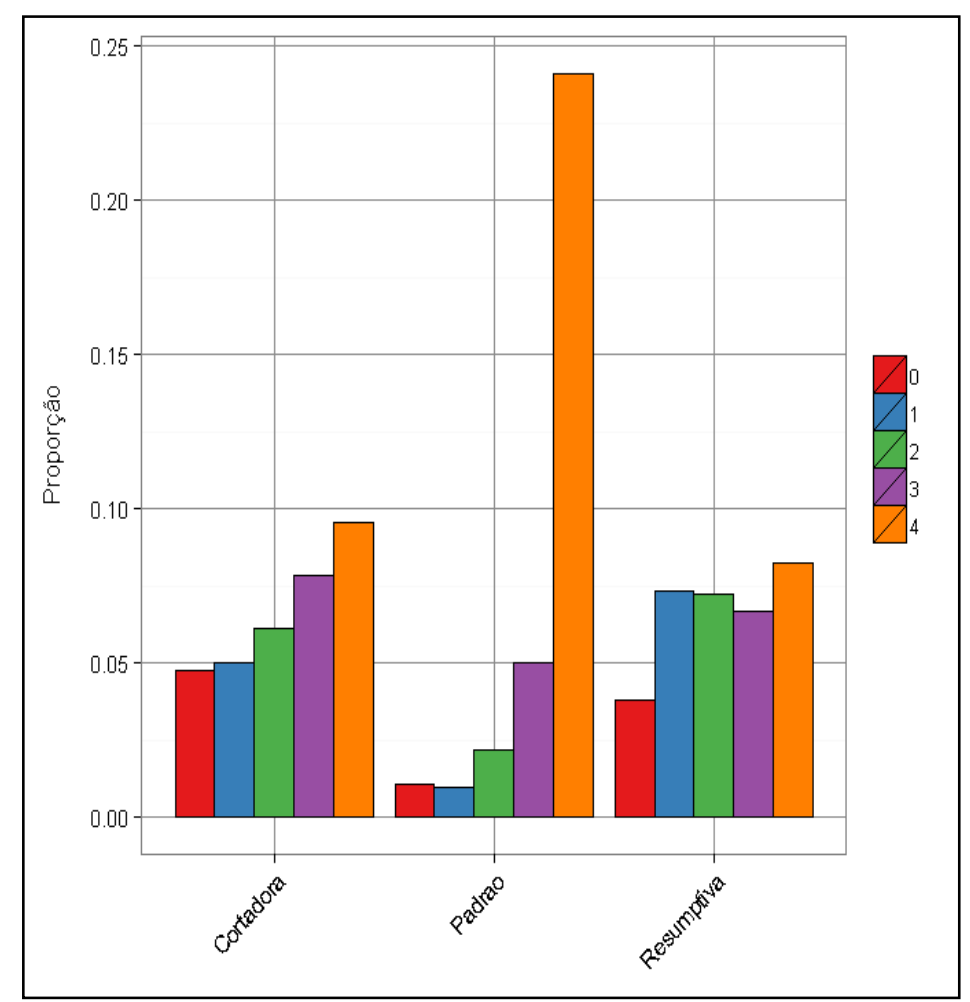

Gráfico 6: Proporção de notas por tipo de relativa - experimento 2

Na comparação entre pares, alguns resultados foram significativos. Para a posição de oblíquo, foram significativos os seguintes contrastes relacionados ao tipo de relativa: a estratégia padrão foi significativamente mais aceita que a cortadora $(Z=90,27 ; p=2,069524 \mathrm{E}-21)$ e a resumptiva $(Z=60,86 ; p=6,10928 \mathrm{E}$ $15)$.

Em relação às relativas de genitivo, a estratégia padrão também foi significativamente mais aceita que as cortadoras $(Z=72,65 ; p=1,54339 \mathrm{E}-17)$ e resumptivas $(\mathrm{Z}=74,95 ; \mathrm{p}=4,815074 \mathrm{E}-18)$.

Em ambas as posições sintáticas, não houve contraste significativo entre resumptivas e cortadoras.

No que tange à posição sintática, a aceitabilidade das relativas de oblíquo foi maior do que a das de genitivo em todos os contrastes feitos. O valor obtido na 
comparação entre as duas posições na estratégia padrão foi $\mathrm{Z}=11,80 ; \mathrm{p}=0,0005$; na cortadora foi $Z=5,63 ; p=0,017$ e na resumptiva, $Z=17,91 ; p=0,00002$.

\section{2 .4}

\section{Discussão dos resultados}

A hipótese de que a estratégia cortadora seria menos custosa e, portanto, teria maior aceitabilidade do que as estratégias padrão e resumptiva não foi sustentada, já que a padrão foi a que apresentou valores mais altos na escala de aceitabilidade, assim como no experimento 1 . Além disso, não foi verificada diferença significativa entre as estratégias não padrão. A preferência pela estrutura padrão pode estar associada à influência do ensino formal, pois, neste experimento, assim como no primeiro, os participantes apresentavam nível de escolaridade alto, sendo altamente influenciado pelo ambiente acadêmico, formal e calcados em uma tradição gramatical de cunho normativista, podendo tê-los feito estranhar as formas não canônicas de relativização. Além disso, o fato de ter sido uma tarefa offline, em que não houve pressão de tempo para o julgamento, pode ter influenciado nos resultados.

Quanto ao contraste entre cortadoras e resumptivas, para o qual não foi verificada diferença estatisticamente relevante, cumpre fazer algumas observações. Primero, diferentemente do ocorre com as relativas padrão, os julgamentos são mais espraiados entre os pontos da escala, conforme pode ser observado na tabela 9. Se, contudo, agruparmos as notas 0 e 1, por um lado, e 3 e 4, por outro (ver tabela 10 abaixo), temos um quadro um pouco mais informativo:

\begin{tabular}{ccccc}
\hline Cortadora & $\begin{array}{c}\text { Cortadora } \\
\text { Oblíquo }\end{array}$ & $\begin{array}{c}\text { Resumptiva } \\
\text { Oblíquo }\end{array}$ & $\begin{array}{c}\text { Resumptiva } \\
\text { Genitiva }\end{array}$ \\
\hline e 1 & $24,3 \%$ & $34,49 \%$ & $33,79 \%$ & $33,09 \%$ \\
2 & $17,36 \%$ & $19,44 \%$ & $19,90 \%$ & $23,61 \%$ \\
3 e 4 & $58,33 \%$ & $46,06 \%$ & $46,29 \%$ & $43,28 \%$ \\
\hline
\end{tabular}

Tabela 10: Percentual de notas agrupadas para cortadoras e resumptivas em posição de oblíquo e genitivo

No caso das relativas de oblíquo, as cortadoras ("o reitor acusou a professora que o inspetor brigou na semana passada") apresentam percentual de aceitação mais alto do que de rejeição; o mesmo ocorre com as de genitivo ("o reitor acusou a 
professora que o inspetor brigou com ela na semana passada"), mas nestas últimas a distância entre os percentuais é menor, não atingindo 50\% a soma das notas 3 e 4 $(46,06 \%)$. Ou seja, embora não tenha sido significativo o contraste, parece ser mais definida a questão da aceitabilidade para as de oblíquo do que para as de genitivo.

Já no caso das relativas resumptivas, as diferenças de percentuais são menos explícitas, tanto para as de oblíquo quanto de genitivo: embora a aceitabilidade seja maior do que a rejeição, a distância entre os percentuais não é tão expressiva, e isso ocorre tanto nas de oblíquo quanto de genitivo. Assim, parece que a presença do resumptivo de alguma forma "perturba"/“divide" os julgamentos.

Em relação especificamente às relativas de genitivo, esperávamos, com base no trabalho de Rodrigues e Dal Pozzo (2017, p. 468), uma diferença entre cortadoras e resumptivas. As autoras verificaram que, em casos de posse inalienável (todos os casos examinados no estudo eram desse tipo), em línguas de pro-drop parcial (PB e Finlandês), o preenchimento da posição do possuidor por pronome pleno foi bem mais aceitável do que o preenchimento por pronome nulo, diferentemente do que se observa para línguas pro-drop pleno (ex. Espanhol e Italiano). No nosso experimento, não houve evidências nessa direção. Ou seja, “A diretora premiou o professor que a aluna dele ganhou uma competição" não difere estatisticamente, em termos de julgamento, de "A diretora premiou o professor que a aluna ganhou uma competição". Note que nos nossos experimentos usamos posse alienável. Este é um tópico a ser explorado em estudos futuros, com a relativa de genitivo em outras posições na sentença, como no exemplo (51), e com um controle rígido da natureza da relação de posse para todos os estímulos (alienável vs. inalienável).

(51) A atriz que o crítico de cinema elogiou a atuação dela/ no filme vai concorrer ao Urso de Ouro.

\section{2 .5}

\section{Discussão geral}

Os experimentos apresentados nesta seção visaram testar a aceitabilidade de pronomes resumptivos em comparação a outras estratégias de relativização em 
diferentes posições sintáticas. De acordo com a literatura, a derivação de relativas padrão envolve custo relacionado à operação de movimento e em LF, sobretudo nas posições preposicionadas, em que há mais elemento a ser carregado durante o movimento. Nesse caso, estratégias cortadoras e resumptivas seriam uma alternativa para minimizar esse custo. É sabido, porém, que as estratégias resumptivas também são custosas, por envolverem custo nas interfaces. Nossos resultados dos experimentos de julgamento de aceitabilidade, no entanto, foram em sentido contrário, revelando uma preferência pela estratégia padrão, o que pode, no caso das relativas preposicionadas, estar relacionado ao perfil de participante testado. No caso das relativas de objeto direto, o pronome foi menos aceito que a forma lacunada, porém não se pode ignorar o fato de que em relação à quantidade de notas atribuídas, essa foi a posição que mais aceitou pronome resumptivo.

Exceto pela posição de sujeito que, claramente, recusa a ocorrência de pronome, observa-se uma distribuição uniforme ao longo das outras condições, em que há sempre um elemento interveniente que dificulta a recuperação do antecedente.

Por se tratar de uma tarefa offline, os testes de julgamento de aceitabilidade captam a percepção do falante em um processo pós processamento, pode ser que o estranhamento gerado pela presença do pronome não seja compatível com o papel facilitador que esse elemento venha a desempenhar no processamento em tempo real. Sendo assim, consideramos importante investigar, por meio de uma tarefa online, o comportamento dos pronomes resumptivos durante o processamento de relativas em situação de compreensão.

\section{3}

\section{Experimentos 3 e 4: escuta automonitorada}

Os experimentos reportados nesta seção avaliam o processamento online por meio da extração dos tempos de escuta - das diferentes estratégias de relativização, buscando mensurar os custos atrelados ao processamento em tarefa de compreensão.

Os fatores analisados foram (i) posição sintática ocupada pelo elemento anafórico: sujeito vs. objeto direto, no experimento 3, e oblíquo vs. genitivo, no experimento 4, e (ii) distância linear entre o elemento anafórico e seu antecedente, 
manipulada a partir da inserção de sintagmas preposicionados adjuntos. Nos dois experimentos também foi manipulado (iii) o tipo de relativa: padrão/cortadora (com lacuna) e resumptiva.

A técnica utilizada foi a escuta automonitorada e o experimento programado no software DMDX 64 .

\subsection{1}

\section{Experimento 3: relativas de sujeito e objeto direto}

As variáveis independentes foram (i) tipo de relativa (padrão vs. resumptiva); (ii) distância linear (curta, média e longa) e (iii) posição sintática (sujeito vs. objeto), essa última tomada como fator grupal.

$\mathrm{O}$ design experimental para cada experimento, $2 \times 3 \times 2$, resultou em 6 condições experimentais para cada grupo, que estão exemplificadas na tabela $11 \mathrm{a}$ seguir, em que as barras separam cada segmento e o trecho em negrito indica o segmento crítico6s:

C2- Média / Resumptivo (MR)

Sujeito: Eu/agradeci/o jogador/que/ele/ leiloou/as chuteiras usadas.

C1- Curta / Resumptivo (CR)

Objeto direto: Eu/conheci/a reitora/que/o formando/ elogiou/ ela/ pela fala / de encerramento.

Sujeito: Eu/agradeci/o jogador/que/no final da partida/ele/ leiloou/as chuteiras usadas.

Objeto direto: $\mathrm{Eu} / \mathrm{conheci} / \mathrm{a}$ reitora/que/após a formatura/ o formando/ elogiou/ ela/ pela fala / de encerramento.

Sujeito: Eu/agradeci/o jogador/que/no final da partida /no jogo beneficente /ele/ leiloou/as chuteiras usadas.

C3- Longa / Resumptivo (LR)

Objeto direto: Eu/conheci/a reitora/que/após a formatura/ no ginásio da faculdade/o formando/ elogiou/ ela/ pela fala / de encerramento.

Sujeito: Eu/agradeci/o jogador/que/ leiloou/as chuteiras

C4- Curta / Lacuna (CL) usadas.

Objeto direto: Eu/conheci/a reitora/que/o formando/ elogiou/ pela fala/ de encerramento.

${ }_{64}$ University of Arizona. Disponível em: http://www.u.arizona.edu/ kforster/dmdx/dmdx.htm ${ }_{65}$ Segmento que pode ser informativo sobre diferença entre as condições testadas, no caso o segmento imediatamente após a posição do pronome/lacuna. 


\begin{tabular}{ll}
\hline & $\begin{array}{l}\text { Sujeito: Eu/agradeci/o jogador/que/no final da } \\
\text { partida/leiloou/as chuteiras usadas. }\end{array}$ \\
C5- Média/Lacuna (ML) & $\begin{array}{l}\text { Objeto direto: Eu/conheci/a reitora/que/após a formatura/ o } \\
\text { formando/ elogiou/pela fala / de encerramento. }\end{array}$ \\
& $\begin{array}{l}\text { Sujeito: Eu/agradeci/o jogador/que/no final da partida/no jogo } \\
\text { beneficente / leiloou / as chuteiras usadas. }\end{array}$ \\
C6- Longa/Lacuna (LL) & $\begin{array}{l}\text { Objeto direto: Eu/conheci/a reitora/que/após a formatura/ no } \\
\text { ginásio da faculdade/o formando/ elogiou/ pela fala / de } \\
\text { encerramento. }\end{array}$ \\
\hline
\end{tabular}

Tabela 11: Exemplos de estímulos usados por condição experimental- experimento 3

As variáveis dependentes foram os tempos de escuta no segmento crítico, que correspondia ao elemento seguinte ao pronome ou lacuna.

\subsubsection{1 \\ Método}

\section{Material}

Foram criadas 24 sentenças experimentais (4 de cada condição) e 48 distratoras66. Para garantir que cada frase só fosse apresentada a cada participante em uma única condição, os estímulos foram organizados em 6 listas por meio de quadrado latino (anexo VIII). Cada lista foi apresentada de forma aleatória para cada participante.

As frases de cada condição obedeceram a um mesmo padrão. Todas eram iniciadas pelo pronome "eu" seguido de um verbo apresentacional e, então, do NP antecedente da relativa, sendo metade deles no masculino e outra metade no feminino. A ideia de se criarem sentenças com essa estrutura visa a garantir que nenhum custo de processamento adicional, além daqueles manipulados no experimento, influenciem os resultados. Por isso, a utilização de um pronome anafórico de primeira pessoa, que, como visto no capítulo 4 (WARREN e GIBSON, 1999), apresenta baixa sobrecarga de processamento, e também a apresentação de toda a oração principal, de modo que seu processamento esteja concluído e sem interrupção quando do advento da oração relativa encaixada.

66 A lista de distratoras usadas nos experimentos 3 e 4 encontra-se no Anexo VI. 
Nas relativas de sujeito curtas, seguindo a oração principal, temos a oração relativa modificadora de sujeito, que apresenta a seguinte estrutura: pronome relativo "que" + pronome resumptivo ou lacuna + verbo trissílabo + NP (nome +adjetivo) (ver exemplos na tabela 8). Em distância média, após a introdução da oração relativa, havia um adjunto adverbial de tempo interveniente, enquanto que, na longa, seguia-se ao adjunto de tempo um adjunto adverbial de lugar.

Nas relativas de objeto direto curtas, após a oração principal ("eu”+ verbo apresentacional + NP) vem a oração relativa, introduzida pelo "que" + NP - de gênero incongruente ao NP antecedente da oração principal-, então um verbo trissílabo, seguido de pronome resumptivo ou lacuna e, dois sintagmas preposicionais (PP). As condições de distância média e longa seguiram a mesma lógica e estrutura das de sujeito, conforme pode ser observado na tabela 8.

Além da estrutura seguida em todas as sentenças, houve controle dos seguintes fatores: animacidade e gênero dos NPs (somente nomes com o traço [+ ANIMADO]), sendo metade no feminino e metade no masculino; tamanho e natureza dos elementos intervenientes nas condições média e longa, sendo esses formados por adjuntos adverbiais de tempo e lugar; verbos trissílabos na oração relativa. Além disso, cada segmento de cada sentença tinha a mesma duração em milissegundos.

Todas as sentenças foram gravadas por inteiro, garantindo uma prosódia mais natural e, em seguida, segmentadas e tratadas no programa Audacity. Foi controlado o tempo de duração, em milissegundos, de cada segmento, garantindo que cada segmento de cada frase tivesse o mesmo tempo em milissegundos.

Já as sentenças distratoras abrangeram cinco diferentes estruturas, sendo (i) $\mathrm{eu}+$ verbo apresentacional + complementizador que (ex: Eu / reconheci/ que/ na semana passada/ em uma praia deserta/ fotografei/ uma modelo /sem permissão); (ii) eu+ NP + verbo apresentacional + complementizador que (ex: Eu e meu amigo/observamos/ que/ durante a viagem/ na estrada perigosa/ o motorista/ dormiu/ no volante); (iii) NP+ complementizador que (ex: O deputado/ admitiu /que/ quando interrogado/ na delegacia/ mentiu /em depoimento); (iv) orações interrogativas indiretas (ex: O vendedor/ perguntou/ que tamanho/ de calça/ a cliente/ levaria/ de presente/para seu marido); (v) complementizadores com pronomes oblíquos (ex: A jornalista/ admitiu /que/o deputado/ assediou-a/ durante uma entrevista/ no gabinete). 
As perguntas de compreensão feitas ao fim de cada sentença visavam a garantir a atenção do participante na tarefa, e eram do tipo sim ou não. Foi criada uma pergunta para cada sentença, de modo que para todas as condições experimentais a pergunta era a mesma (Anexo VII).

\section{Participantes}

Para o grupo das relativas de sujeito, 24 participantes -4 em cada lista participaram da tarefa, porém 1 foi eliminado pelo fato de o tempo de escuta estar 2 desvios padrão afastado da média. Os 23 participantes contabilizados são residentes do Rio de Janeiro, predominantemente do sexo feminino (59,09\%), cursam ensino médio e/ou técnico em uma escola federal e têm, em média 23,59 anos67 (desvio padrão: 7,42).

O grupo de participantes que avaliaram relativas de objeto direto também era formado por 24 estudantes, porém 2 foram eliminados por terem apresentado tempo de reação do segmento crítico inferior ao tempo total de duração do segmento, o que significa que acionaram a passagem antes de terem ouvido todo o segmento. Outros 2 foram eliminados, posteriormente, por estarem 2 desvios padrão distantes da média. Os 20 participantes contabilizados também são todos naturais do Rio de Janeiro, são em sua maioria do sexo feminino (55\%), cursam ensino médio e/ou técnico em uma escola federal e têm, em média 26,25 anos (desvio padrão: 9,28).

\section{Procedimento}

Antes da aplicação do teste, a pesquisadora explicou aos informantes em que consistia a tarefa e, em seguida, solicitou que lessem e assinassem o termo de consentimento livre e esclarecido (anexo VI).

O teste foi realizado em um ambiente confortável e livre de ruídos, com duração média de 20 minutos. Foi utilizado um laptop e fones de ouvido.

O experimento tinha início com a apresentação, na tela do computador, das instruções a serem seguidas na atividade. Neste momento, a pesquisadora enfatizou 
a necessidade de o participante ouvir todo o segmento para somente então passar para o próximo. Tal orientação foi importante a fim de garantir que o participante ouvisse o trecho por completo e não fosse descartado posteriormente. Em seguida, passou-se à fase de treino, acompanhada pela pesquisadora, que sanou possíveis dúvidas. Após sentir-se apto, o participante era, então, deixado sozinho na sala para a realização da tarefa.

A tarefa consistia na escuta de segmentos que formavam uma frase. A passagem de cada fragmento era controlada pelo participante por meio da barra de espaço. O tempo de reação era computado a partir do momento que o participante pressionava a barra de espaço.

Ao final de cada sentença, aparecia na tela uma pergunta interpretativa a ser respondida, a fim de garantir que o participante não realizasse a tarefa de forma automática. O tempo máximo para passagem dos segmentos e para resposta às perguntas era de 8000 milissegundos.

\subsubsection{2 \\ Hipóteses e previsões}

Tendo em vista os possíveis fatores de custo associados ao processamento de orações relativas, nossa hipótese é que com o aumento da distância linear entre o elemento anafórico (lacuna/pronome resumptivo) e seu antecedente, a dificuldade de processamento também aumenta, o que se refletirá em tempos de escuta maiores para as relativas longas.

Em relação à variável posição sintática, diversos estudos experimentais, que se encontram reportados no capítulo 4, apresentam evidências de que relativas de objeto direto são mais difíceis de serem processadas. Nessa posição, conforme visto em capítulos anteriores, há um elemento interveniente (DP sujeito da relativa), que torna o antecedente mais distante e, portanto, menos acessível (ARIEL, 1999). O alto custo de processamento dessas relativas relaciona-se à necessidade de manutenção de dois elementos na memória de trabalho - o antecedente e o DP interveniente -, à recuperação do antecedente, que se encontra menos acessível, e a sua integração à estrutura processada. Já nas relativas de sujeito, em que não há elemento interventor, o elemento anafórico e seu antecedente estão próximos, o que facilita sua recuperação. Dessa forma, é esperado que relativas de sujeito sejam 
mais fáceis de serem processadas, apresentando tempos de escuta menores que as de objeto direto.

Quanto ao tipo de relativa, assumimos que a acessibilidade do antecedente na memória é fator que afeta o tipo de elemento a ser usado na retomada. No capítulo 2, foram reportados resultados de estudos sociolinguísticos que mostram ser distância linear um fator que influencia o tipo de estratégia de relativização usada pelo falante, com aumento no número de resumptivos associado à distância longa (MOLLICA, 1997; 2003). Foi visto no capítulo 4 que a distância e a natureza das informações entre o antecedente e o elemento anafórico impacta o processo de armazenamento e de integração no processamento da correferência (GIBSON, 2000;2005). Especificamente quanto ao elemento usado na retomada, foi apresentada a proposta de Ariel (1999), segundo a qual pronomes resumptivos são usados em contextos em que o antecedente está menos acessível, sendo distância entre o antecedente e o elemento anafórico relevante na definição do tipo de elemento usado. Dessa forma, é esperado que, à medida que a distância linear é ampliada (no caso, com a inclusão de sintagmas adjuntos), os resumptivos sejam ouvidos mais rapidamente. Portanto, espera-se que os resumptivos tenham tempos de escuta menores que as lacunas em distância longa, dado que os pronomes podem facilitar a recuperação do antecedente da relativa. Para as relativas de objeto direto em dependências longas, é esperado resultados compatíveis com os obtidos por Hofmeister e Norcliffe (2013), com os resumptivos facilitando o processamento nesse contexto. No caso das relativas de sujeito, espera-se um efeito menor, visto que estas são menos complexas do que as relativas de objeto e não há um DP em posição sintática que possa gerar efeito de intervenção.

\subsubsection{3}

\section{Resultados}

A tabela a seguir apresenta os resultados referentes à estatística descritiva dos tempos de escuta, para relativas de sujeito e de objeto, em cada uma das 6 condições testadas. 
SU JEITO

\begin{tabular}{|c|c|c|c|c|c|c|c|c|c|c|}
\hline & Média & Mediana & $\begin{array}{l}\text { Desvio } \\
\text { Padrão }\end{array}$ & $\begin{array}{l}\text { Valor } \\
\text { mínimo }\end{array}$ & $\begin{array}{l}\text { Valor } \\
\text { máximo }\end{array}$ & Média & Mediana & $\begin{array}{l}\text { Desvio } \\
\text { Padrão }\end{array}$ & $\begin{array}{l}\text { Valor } \\
\text { mínimo }\end{array}$ & $\begin{array}{l}\text { Valor } \\
\text { máximo }\end{array}$ \\
\hline $\mathrm{Cl}$ & 154,96 & 129,18 & 98,25 & 41,30 & 355,54 & 154,96 & 173,78 & 62,19 & 35,05 & 244,27 \\
\hline $\mathrm{C}_{2}$ & 175,13 & 150,79 & 104,60 & 70,30 & 359,59 & 187,33 & 166,32 & 89,35 & 58,68 & 352,93 \\
\hline $\mathrm{C}_{3}$ & 172,44 & 175,13 & 112,10 & 64,28 & 565,37 & 307,24 & 302,95 & 90,89 & 203,95 & 576,62 \\
\hline $\mathrm{C}_{4}$ & 181,77 & 168,87 & 115,62 & 40,27 & 465,89 & 192,07 & 202,42 & 93,74 & 69,12 & 425,48 \\
\hline C5 & 172,32 & 167,56 & 110,70 & 24,99 & 472,26 & 212,85 & 190,51 & 103,73 & 22,19 & 416,21 \\
\hline C 6 & 246,16 & 246,39 & 114,85 & 77,44 & 500,36 & 340,17 & 323,23 & 93,74 & 209,83 & 626,61 \\
\hline
\end{tabular}

Tabela 12: Estatística descritiva para relativas de sujeito e objeto direto experimento 3

$C 1=$ Curta/Resumptivo; $C 2=$ Média/Resumptivo; $C 3=$ Longa/Resumptivo $; C 4=$ Curta/Lacuna; C5= Média/Lacuna; C6= Longa/Lacuna

Os tempos de escuta do segmento crítico (segmento após elemento anafórico) foram submetidos à análise da variância e foi verificado efeito principal para a variável posição sintática, com as médias do tempo de escuta para as relativas de objeto direto $(232,43 \mathrm{~ms})$ sendo significativamente maiores em relação às de sujeito $(183,79 \mathrm{~ms}): \mathrm{F}(1,42)=7,381 ; \mathrm{p}=0,01$. O gráfico 7 a seguir ilustra a diferença encontrada:

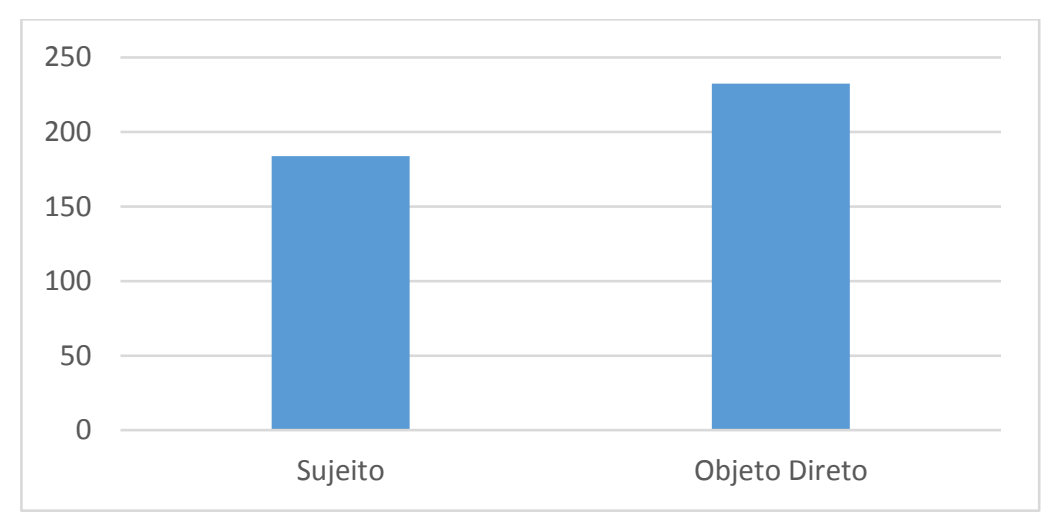

Gráfico 7: Médias dos tempos de escuta do segmento crítico em função da posição sintática experimento 3

Para a variável distância linear, a média dos tempos de escuta do segmento crítico em distância longa foi de $266,50 \mathrm{~ms}$, em oposição aos valores obtidos para distância curta e média que foram, respectivamente, de 170,94 ms e 186,91 ms, uma diferença significativa do ponto de vista estatístico $(F(1,42)=52,605 ; p=0,0001)$. O gráfico seguinte mostra as diferenças encontradas: 


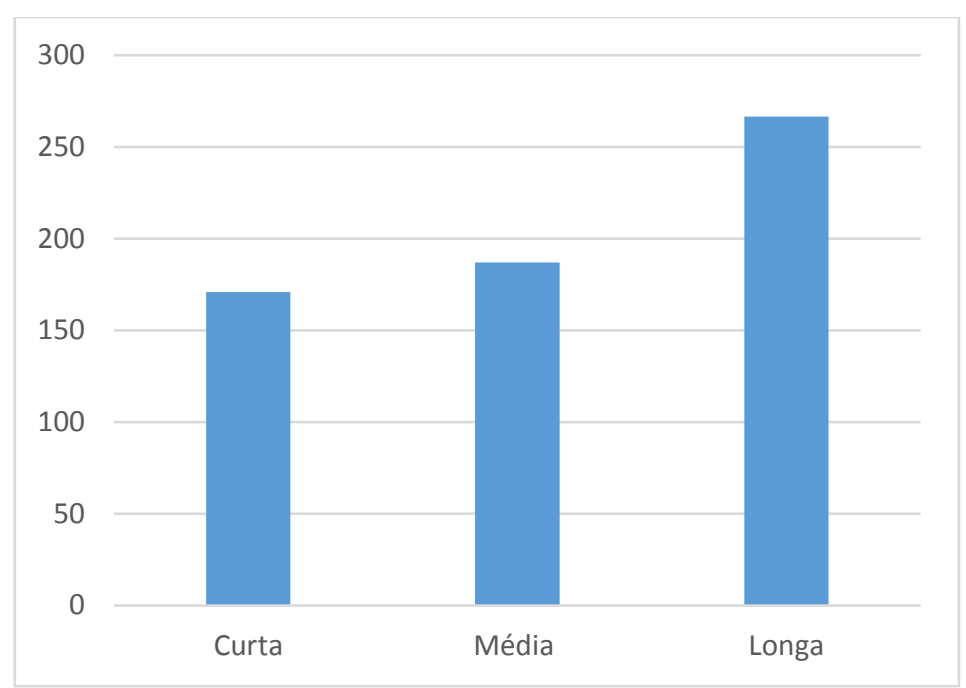

Gráfico 8: Médias dos tempos de escuta do segmento crítico em função da distância linear - experimento 3

Houve efeito principal para tipo de relativa $(\mathrm{F}(1,42)=19,386 ; \mathrm{p}=0,0001)$, com as resumptivas apresentando tempos menores (192,01 ms vs 224,22 ms):

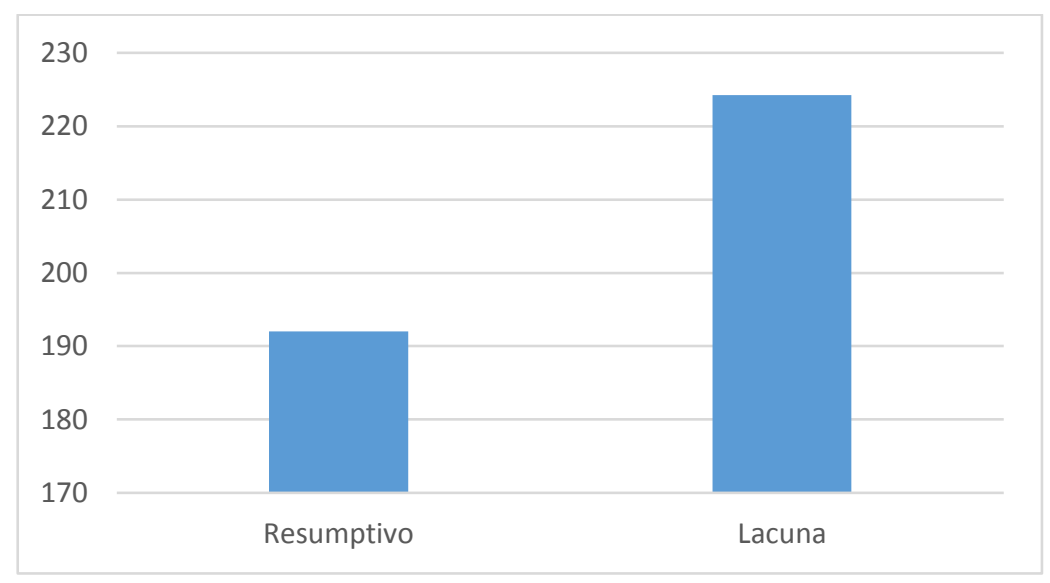

Gráfico 9: Médias dos tempos de escuta do segmento crítico em função do tipo de relativa - experimento 3

A interação entre posição sintática e distância linear foi significativa (F $(1,42)=17,188 ; \mathrm{p}=0,0001)$. No gráfico a seguir nota-se que com o aumento da distância, o tempo de processamento se torna maior, principalmente para a posição de objeto direto: 


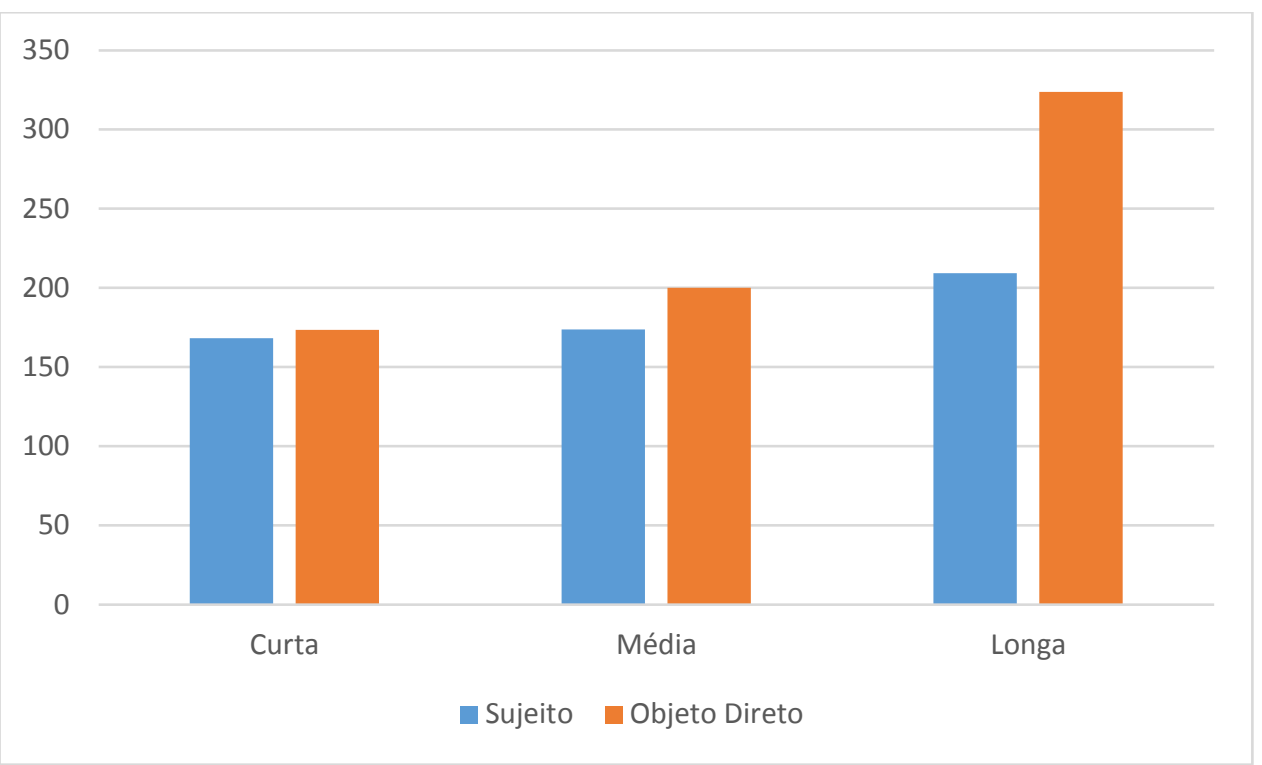

Gráfico 10: Médias dos tempos de escuta do segmento crítico em função da posição sintática e da distância linear- experimento 3

Não houve efeito de interação entre as variáveis tipo de relativa $v s$. distância linear. Também não foi verificado efeito de interação entre as três variáveis independentes examinadas (tipo de relativa vs. distância linear vs. posição sintática).

Reportaremos a seguir os contrastes em pares que foram significativos:

Padrão de sujeito vs. objeto direto em distância longa: $(\mathrm{t}(42)=-3,350$; $\mathrm{p}=0,002)$, com as relativas de sujeito apresentando tempo de escuta menor $(340,17$ ms vs $246,16 \mathrm{~ms})$.

Resumptiva de sujeito vs. objeto direto em distância longa: $(t(42)=-5,733$; $\mathrm{p}=0,0001)$, com relativas de sujeito apresentando tempos de escuta menor $(307,24$ ms vs. 172,44 ms).

\section{Padrão de sujeito em função da distância:}

-distância curta $v s$. distância longa: $\mathrm{t}(22)=-2,0375 \mathrm{p}=0,0538$, com as curtas tendo tempos menores $(246,16 \mathrm{~ms} v s .181,77 \mathrm{~ms})$.

-distância média $v s$ distância longa: $\mathrm{t}(22)=-2,472 \mathrm{p}=0,0216$, com tempos maiores para as longas (246,16 $\mathrm{ms} v s 172,32 \mathrm{~ms})$.

\section{Relativas de sujeito em função do tipo de relativa e distância:}

- resumptivo vs. lacuna em distância longa: $\mathrm{t}(22)=-3,311 \mathrm{p}=0,0032$, com os resumptivos tendo tempos menores (246,16 ms vs. 172,44 ms). 


\section{Resumptivas de objeto direto em função da distância:}

-distância curta $v s$ distância longa: $\mathrm{t}(19)=-8,539 \mathrm{p}=0,0001$, com as curtas tendo tempos menores (307,24 ms vs 154,96 ms).

-distância curta vs média: $\mathrm{t}(19)=-5,813 ; \mathrm{p}=0,0001$, com as curtas tendo tempos, significativamente menores (187,33 vs $154,96 \mathrm{~ms})$.

\section{Padrão de objeto direto em função da distância:}

-distância curta vs distância longa: $(\mathrm{t}(19)=-8,168 ; \mathrm{p}=0,0001)$, com as curtas tendo tempos menores $(340,17 \mathrm{~ms}$ vs $192,07 \mathrm{~ms})$.

-distância média vs distância longa: $\mathrm{t}(19)=-5,509 ; \mathrm{p}=0,0001$, com a média tendo tempo de escuta menor (340,17 ms vs $212,85 \mathrm{~ms})$.

\section{Relativas de objeto direto em função do tipo de relativa e distância:}

-resumptivo vs lacuna em distância curta: $t(19)=-2,329 \quad p=0,03$, com resumptivos tendo tempos menores (192,07 ms vs 154,96 ms).

-resumptivo vs lacuna em distância longa: $p=0,037159$, com resumptivos tendo tempos menores (340,17 ms vs 307,24 ms).

\subsubsection{4}

\section{Discussão dos resultados}

Os resultados para a variável posição sintática indicam que as relativas de objeto direto apresentam maior dificuldade de processamento em relação às de sujeito, o que está de acordo com a literatura revisada. O processamento de relativas de objeto direto impõe mais sobrecarga ao processador linguístico, devido à necessidade de manutenção de mais material linguístico na memória. Vejamos um exemplo: no curso do processamento sintático de uma relativa de objeto direto como "a aluna que o professor elogiou recebeu um prêmio", o processador linguístico deve manter na memória o antecedente "a aluna" e também "o professor", um DP interventor de mesma natureza que "a aluna" que deve se manter ativo na memória até que o processamento seja concluído e a devida referência entre a lacuna e "a aluna" seja estabelecida. Em uma relativa de sujeito, por outro lado, como em "a aluna que recebeu um prêmio", não há fator que dificulte a rápida 
retomada no antecedente, visto que não existe outro possível DP para ocupar a posição de antecedente.

Quanto ao fator distância linear, foi verificado que o aumento deste tipo de distância torna o processamento mais lento, sobretudo das relativas de objeto direto. Era esperado que, com o aumento da distância linear, o tempo de processamento de relativas resumptivas diminuísse. Em contexto de maior distância, de acordo com o princípio da acessibilidade de Ariel (1999), o antecedente da oração relativa está menos acessível e a ocorrência do pronome resumptivo favoreceria a sua recuperação. Nossos resultados, entretanto, não mostraram efeito de interação entre distância e tipo de relativa que permita confirmar essa hipótese. Cabe notar, no entanto, que as médias de tempo de escuta do segmento crítico foram na direção esperada, com o tempo de processamento das resumptivas sendo menor (em relação às padrão) à medida que a distância aumenta: distância curta (154, 96 ms vs 186,92 ms); distância média (181,23 ms vs 192,58 ms); distância longa (239,94 ms vs 293,16 ms).

Havia, ainda, a expectativa de que relativas resumptivas de objeto direto fossem processadas mais rápidas que a padrão em distância longa, na mesma direção dos dados obtidos por Hofmeister e Norcliffe (2013) para o inglês, cujos resultados apontam para maior favorecimento de resumptivos (vs. lacunas) em dependências longas. Os resultados obtidos confirmaram essa previsão. É importante ressaltar, no entanto, que os autores em questão utilizaram um design experimental diferente do nosso. Os autores contrastaram dependências curtas e longas que envolviam distância hierárquica. A dependência curta era constituída por uma oração relativa, enquanto que na longa, além da relativa, havia também uma oração completiva. Nessa configuração, o antecedente está muito mais encaixado e distante -linear e hierarquicamente - do elemento anafórico.

Destaca-se aqui que nas relativas de objeto direto, os resumptivos facilitaram o processamento também em distância curta, se comparados às lacunas. Nessa posição, conforme visto anteriormente, há sempre um elemento interventor que torna o processamento mais difícil. Assim, mesmo quando não há outro fator de custo, no caso distância, o pronome resumptivo parece ter um papel importante, facilitando o processamento. Em distância média, não houve diferença significativa entre resumptivos e lacunas, porém as médias de tempo de escuta são maiores para as relativas lacunadas $(212,85 \mathrm{~ms} v s .187,33 \mathrm{~ms})$, como era esperado. 
Em relação às de sujeito, a expectativa era encontrar um efeito menos evidente do fator distância, já que é uma estrutura menos complexa que a de objeto direto, pois não tem efeito de intervenção. Os dados obtidos mostram que, embora não exista nas relativas de sujeito um fator intrínseco de custo como nas de objeto direto, o aumento da distância linear torna o processamento mais difícil, lento, já que o antecedente está mais distante e menos acessível. Em distância longa, portanto, a presença do resumptivo facilita a retomada do antecedente, tornando o processamento mais eficiente. Esses dados estão em convergência com os dados de fala analisados por Mollica (2003), que mostram a variável distância como fator de custo que eleva as chances de ocorrência de pronome resumptivo na posição de sujeito.

Ainda na posição de sujeito, deve-se observar que as lacunas não foram favorecidas - em relação aos resumptivos - nem mesmo em distância curta. Em PB, sabe-se que é possível tanto a omissão, quanto o preenchimento da posição sujeito. Estudos diacrônicos (LESSA-DE-OLIVEIRA, 2009; MOLLICA, 2003) mostram que ao longo do tempo, o PB deixou de ser uma língua predominantemente de sujeito nulo, para ser, preferencialmente, uma língua com sujeito manifesto, isto é, realizado foneticamente por meio de um pronome pleno. No que diz respeito ao processamento sintático, parece que a natureza do sujeito (omisso ou realizado) é indiferente ao parser.

\section{3 .2}

\section{Experimento 4: relativas de oblíquo e genitivo}

No quarto experimento, foram manipuladas as seguintes variáveis: (i) tipo de relativa (cortadora $v s$. resumptiva); (ii) distância linear (curta, média e longa) e (iii) posição sintática (oblíquo vs. genitivo), essa última variável tomada como fator grupal para que o experimento não ficasse muito longo.

A variável dependente foi o tempo de escuta do segmento crítico. As condições experimentais resultantes da manipulação das variáveis aparecem na tabela 13 a seguir, em que o trecho em negrito indica o segmento crítico. 
C1- Curta / Resumptivo (CR)

C2- Média / Resumptivo (MR)

C3- Longa / Resumptivo (LR)

C4- Curta / Lacuna (CL)

C5- Média/Lacuna (ML)

C6- Longa/Lacuna (LL)
Oblíquo: Eu/defendi/ o cozinheiro/ que/a garçonete/discutiu/ com ele/sobre o preparo /da refeição.

Genitivo: Eu / reconheci / a jogadora / que /o adversário /dela / atendeu /a imprensa local.

Oblíquo: Eu/abracei/ o cozinheiro/ que/na hora do jantar/a garçonete/discutiu/ com ele/sobre o preparo / da refeição.

Genitivo: Eu / reconheci / a jogadora / que /no final da partida /o adversário /dela / atendeu /a imprensa local.

Oblíquo: Eu/defendi/ o cozinheiro/ que/na hora do jantar/dentro do restaurante/a garçonete/discutiu/ com ele/sobre o preparo/da refeição.

Genitivo: Eu / reconheci / a jogadora / que /no final da partida /dentro do vestiário/ o adversário /dela / atendeu /a imprensa local.

Oblíquo: Eu/defendi/ o cozinheiro/ que/a garçonete/discutiu/ sobre o preparo /da refeição.

Genitivo: Eu / reconheci / a jogadora / que /o adversário /atendeu /a imprensa local.

Oblíquo: Eu/abracei/ o cozinheiro/ que/na hora do jantar/a garçonete/discutiu/sobre o preparo / da refeição.

Genitivo: Eu / reconheci / a jogadora / que /no final da partida /o adversário / atendeu /a imprensa local.

Oblíquo: Eu/defendi/ o cozinheiro/ que/na hora do jantar/dentro do restaurante/a garçonete/discutiu/ sobre o preparo /da refeição.

Genitivo: Eu / reconheci / a jogadora / que /no final da partida /dentro do vestiário/ o adversário /atendeu /a imprensa local.

Tabela 13: Exemplos de estímulos usados por condição experimental- experimento 4

\subsubsection{1}

Método

\section{Material}

O material utilizado seguiu o mesmo padrão do experimento 3. Assim como no experimento anterior, na gravação dos estímulos, garantimos que cada segmento de cada sentença tivesse a mesma duração em milissegundos.

\section{Participantes}

24 participantes de cada grupo realizaram a tarefa, porém, no grupo oblíquo, 2 foram eliminados por terem tido tempo de escuta inferior à duração total do 
segmento crítico $(1440 \mathrm{~ms})$ e 2 por terem apresentado tempos de escuta discrepantes da média em 2 desvios padrão. Os 20 participantes contabilizados para análise são graduandos residentes no Rio de Janeiro, com idade média de 31,3 anos (desvio padrão de 7,31 e do sexo feminino (58,33\%).

No grupo de genitivo, houve 3 eliminados no total, sendo 1 por não ter escutado todo o segmento crítico e 2 por terem apresentado tempos de escuta discrepantes da média em 2 desvios padrão, resultando em 21 participantes para análise. Este grupo também é formado por graduandos do Rio de Janeiro com idade média de 25,47 anos (desvio padrão 2,88) e majoritariamente do sexo feminino $(70,83 \%)$.

\section{Procedimento}

O mesmo seguido no experimento 3 .

\subsubsection{2 \\ Hipóteses e previsões}

Estudos em processamento convergem para a ideia de que relativas encabeçadas por um PP e genitivas são mais custosas ao processamento (para maior detalhamento, cf. capítulo 4). Assim como nas relativas de objeto direto, há custo associado à intervenção de material linguístico entre os elementos correferentes, como nos exemplos "...o cozinheiro que a garconete discutiu com ele sobre o preparo da refeição” e “... a jogadora que o adversário dela atendeu a imprensa local”, em que o parser necessita manter na memória de trabalho o DP interveniente ("a garçonete e o adversário"), além do elemento relativizado, que deve ser recuperado e então integrado na estrutura construída, o que despende mais recursos. No entanto, nas relativas de genitivo, o elemento anafórico (lacuna ou pronome resumptivo) está mais próximo de seu antecedente, o que o torna mais acessível à memória de trabalho, embora não se deva ignorar que, em termos derivacionais, essas estruturas apresentam uma ilha sintática. Nessas posições, é possível a aplicação das três estratégias de relativização, porém neste experimento contrastamos apenas as duas formas não-padrão: cortadoras e resumptivas. Relembrando, como mencionado no capítulo 3 e no experimento anterior, que 
mesmo cortadoras e resumptivas são estruturas que apresentam algum tipo de custo, sendo a cortadora mais econômica.

Em relação ao tipo de relativa, tendo em vista as diferentes previsões de custo para cortadoras e resumptivas, nossa hipótese é de que quando não há outro fator de custo (distância linear) além do elemento interventor, a estratégia cortadora será favorecida, apresentando tempos de escuta menores. Ao contrário, quando há aumento da distância linear, a estratégia resumptiva deve ser favorecida, pois, nesse caso, o antecedente está menos acessível e a presença do pronome, apesar de custosa, torna o processamento menos complexo, já que o resumptivo facilita a recuperação do antecedente.

Quanto à posição sintática, é esperada uma diferença entre o tempo de processamento de relativas de oblíquo e de genitivo. Nas genitivas, conforme já apresentado no experimento 2, a relativa está encaixada no sujeito da oração principal, o que torna os elementos correferentes mais próximos e o antecedente mais acessível. Dessa forma, é esperado tempos de escuta menores nessa posição.

\subsubsection{3}

\section{Resultados}

Abaixo, apresentamos os dados de estatística descritiva para as relativas investigadas:

\begin{tabular}{|c|c|c|c|c|c|c|c|c|c|c|}
\hline & \multicolumn{5}{|c|}{ OBLÍQUO } & \multicolumn{5}{|c|}{ GENITIVO } \\
\hline & Média & Mediana & $\begin{array}{l}\text { Desvio } \\
\text { Padrão }\end{array}$ & $\begin{array}{l}\text { Valor } \\
\text { mínimo }\end{array}$ & $\begin{array}{l}\text { Valor } \\
\text { máximo }\end{array}$ & Média & Mediana & $\begin{array}{l}\text { Desvio } \\
\text { Padrão }\end{array}$ & $\begin{array}{l}\text { Valor } \\
\text { mínimo }\end{array}$ & $\begin{array}{l}\text { Valor } \\
\text { máximo }\end{array}$ \\
\hline $\mathrm{C1}$ & 172,47 & 156,33 & 98,25 & 41,30 & 355,54 & 130,56 & 113,03 & 62,19 & 35,05 & 244,27 \\
\hline $\mathrm{C} 2$ & 189,45 & 164,72 & 104,60 & 70,30 & 359,59 & 211,39 & 201,26 & 89,35 & 58,68 & 352,93 \\
\hline $\mathrm{C} 3$ & 318,94 & 317,99 & 112,10 & 64,28 & 565,37 & 345,75 & 352,63 & 90,89 & 203,95 & 576,62 \\
\hline C4 & 212,09 & 168,87 & 115,62 & 40,27 & 465,89 & 219,86 & 192,81 & 93,74 & 69,12 & 425,48 \\
\hline $\mathrm{C} 5$ & 265,11 & 271,12 & 110,70 & 24,99 & 472,26 & 289,23 & 272,85 & 103,73 & 22,19 & 416,21 \\
\hline C6 & 282,86 & 271,47 & 114,85 & 77,44 & 500,36 & 401,34 & 390,09 & 93,74 & 209,83 & 626,61 \\
\hline
\end{tabular}

Tabela 14: Estatística descritiva para relativas de oblíquo e genitivo- experimento 4 $C 1=$ Curta/Resumptivo; $C 2=$ Média/Resumptivo; $C 3=$ Longa/Resumptivo; $C 4=$ Curta/Lacuna; C5= Média/Lacuna; $C 6=$ Longa/Lacuna

O teste estatístico Anova mostrou efeito significativo para a variável distância linear, $\mathrm{F}(1,40)=90,617 ; \mathrm{p}=0,0001$. O gráfico abaixo mostra as médias 
obtidas. Note que o tempo médio de escuta do segmento crítico aumenta em função da distância: distância curta apresenta tempos menores de escuta $(183,75 \mathrm{~ms})$ do que a distância média (238,80 ms) e essa menor do que a longa (337,23 ms).

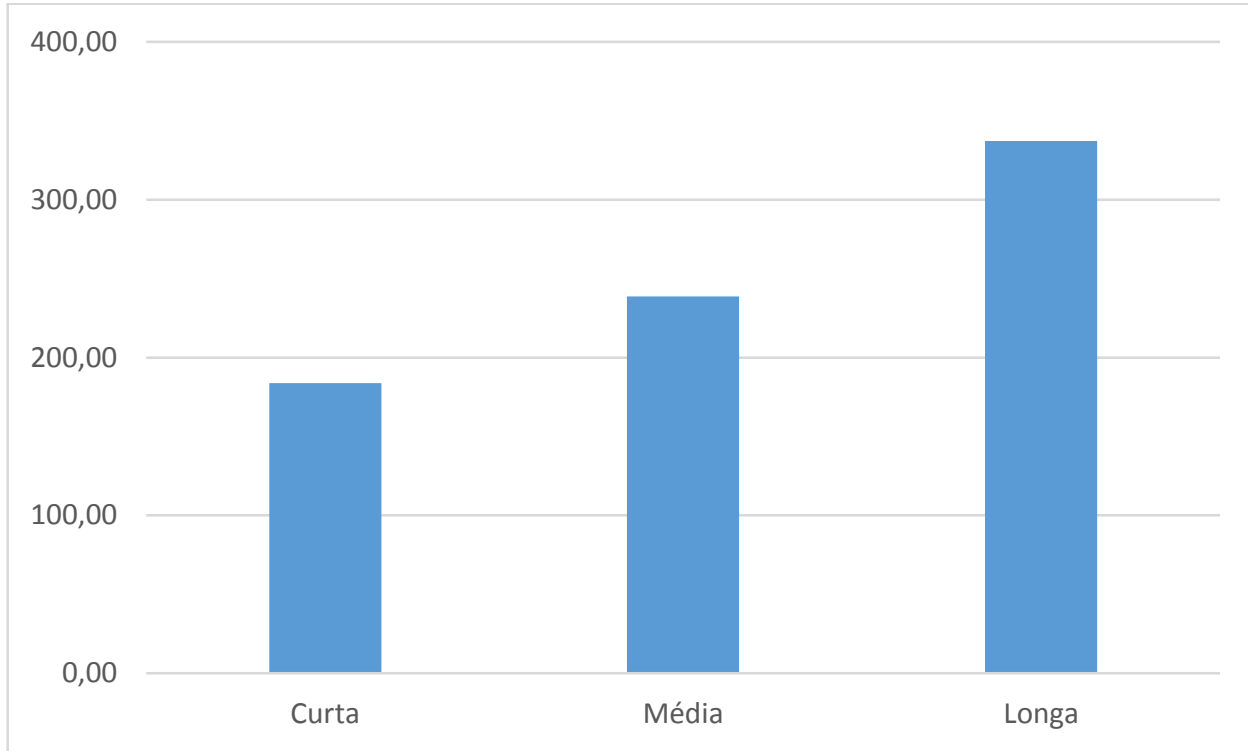

Gráfico 11: Médias dos tempos de escuta do segmento crítico em função da distância linear- experimento 4

A variável tipo de relativa também apresentou efeito significativo $(\mathrm{F}(1,40)=$ 23,685; $p=0,0001)$. As médias obtidas para cada tipo de relativa mostram tempos menores para resumptivas $(228,10 \mathrm{~ms})$ em relação às cortadoras $(278,42 \mathrm{~ms})$ :

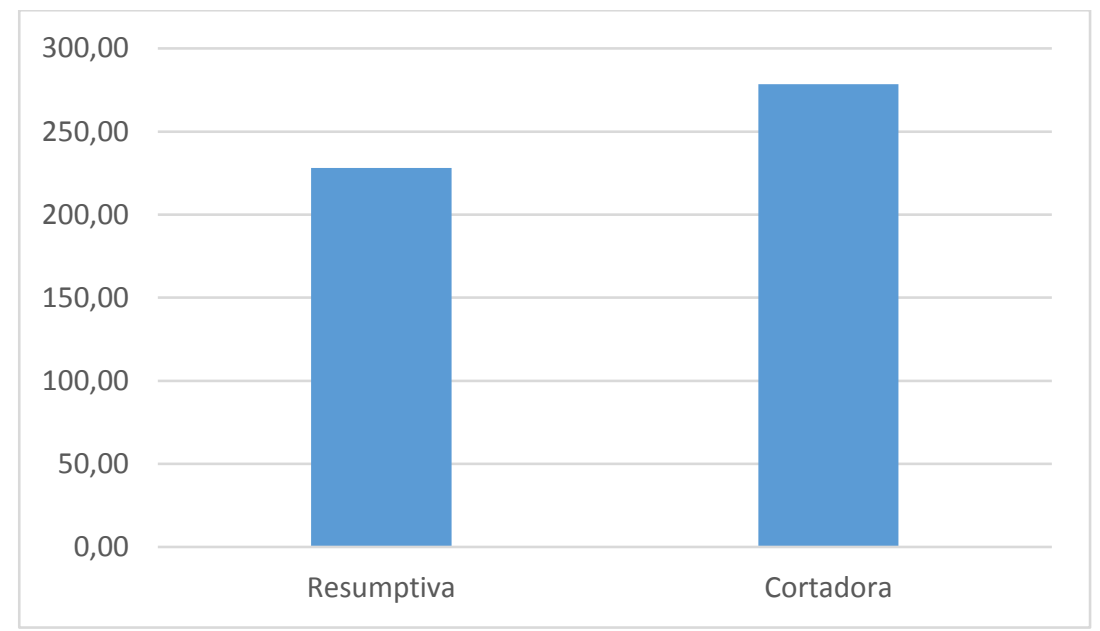

Gráfico 12: Médias dos tempos de escuta do segmento crítico em função do tipo de relativa experimento 4 
Embora não tenha havido efeito principal de posição sintática, na interação com distância linear e tipo de relativa, os resultados foram significativos: $(\mathrm{F}(1,40)$ $=6,172 ; \mathrm{p}=0,01)$. No gráfico 13 abaixo, observa-se que as relativas apresentam tempos maiores em função do aumento da distância linear, especialmente na posição de genitivo, em que esse incremento temporal é mais evidente:

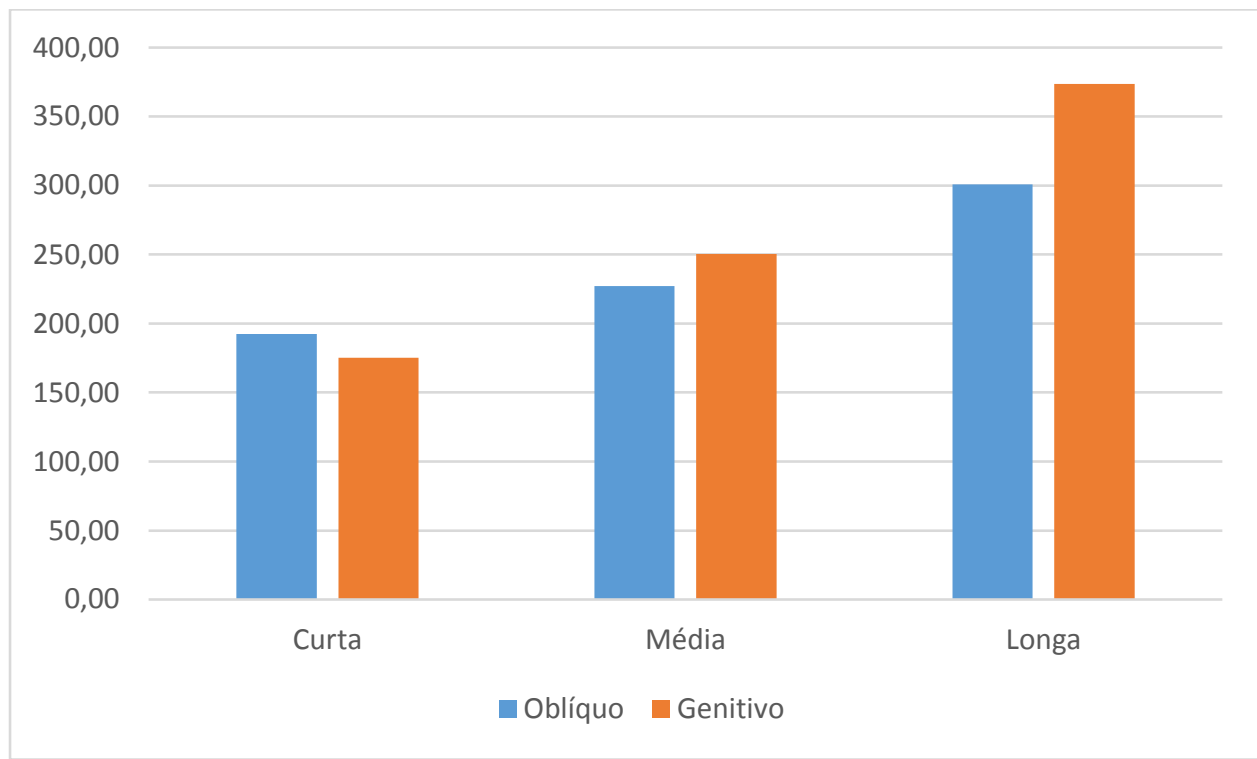

Gráfico 13: Médias dos tempos de escuta do segmento crítico em função da posição sintática e da distância linear - experimento 4

Em relação à interação entre posição sintática e tipo de relativa, os resultados sugerem que na posição de genitivo o processamento de relativas cortadoras é, significativamente, mais lento: $(\mathrm{F}(1,40)=4,931 ; \mathrm{p}=0,03)$. O gráfico a seguir apresenta as médias encontradas: 


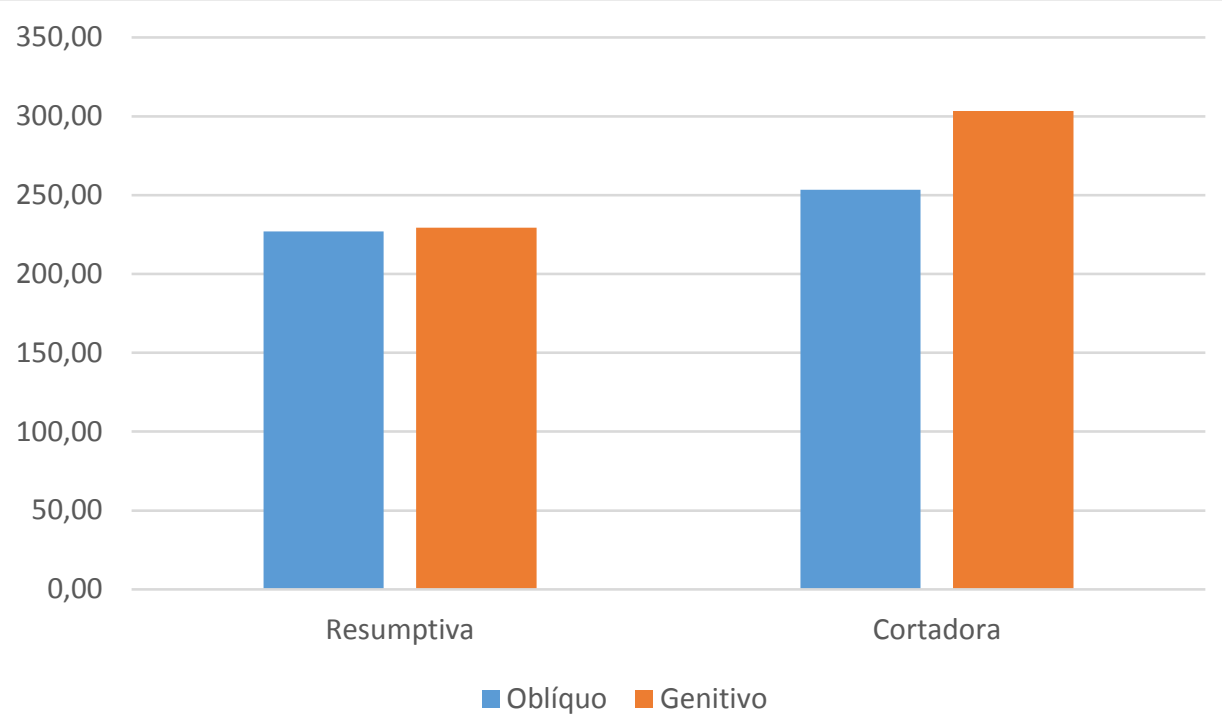

Gráfico 14: Médias dos tempos de escuta do segmento crítico em função da posição sintática e do tipo de relativa -experimento 4

Houve também interação entre tipo de relativa e distância linear. No gráfico 15 , nota-se que o tempo de processamento de relativas cortadoras e resumptivas é

maior à medida que a distância aumenta $(\mathrm{F}(1,40)=5,348 ; \mathrm{p}=0,02)$ :

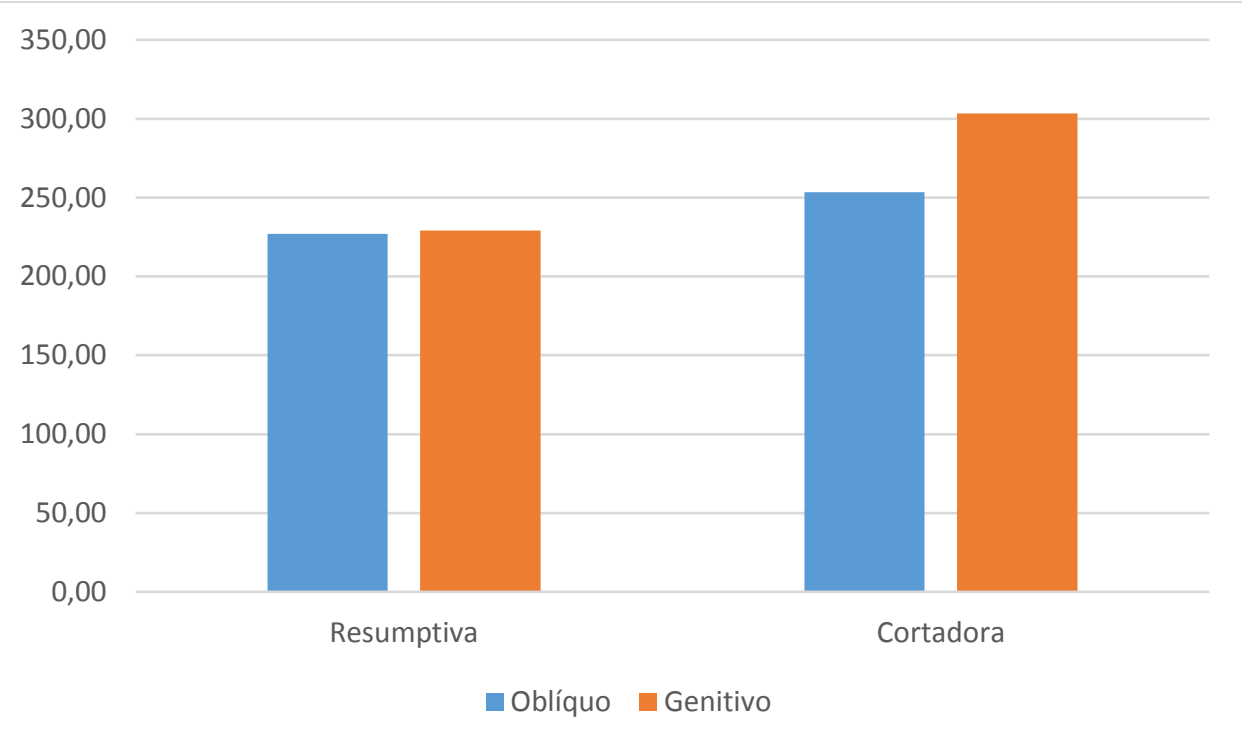

Gráfico 15: Médias dos tempos de escuta do segmento crítico em função do tipo de relativa e distância linear -experimento 4

Não houve efeito de interação entre as três variáveis manipuladas (tipo de relativa vs. distância linear vs. posição sintática). 
A seguir reportam-se, de forma sintética, os resultados relativos à comparação entre pares. Serão apresentados apenas os contrastes cuja análise estatística revelou efeito significativo:

Resumptivas de genitivo vs. de oblíquo em distância curta: $t(40)=1,993$; $\mathrm{p}=0,05$, com tempos maiores de escuta do segmento crítico para as de oblíquo $(172,47 \mathrm{~ms}$ vs. $130,56 \mathrm{~ms})$.

Cortadoras de genitivo vs. de oblíquo em distância longa: $t(40)=-3,279$; $\mathrm{p}=0,002$, com tempos maiores de escuta do segmento crítico para as de genitivo (401,35 ms vs. $282,86 \mathrm{~ms})$.

\section{Resumptivas de oblíquo em função da distância:}

- distância curta vs. distância longa: $\mathrm{t}(19)=-4,818 ; \mathrm{p}=0,0001$, com tempos maiores de escuta do segmento crítico para as longas (282, 86 ms vs. 172,47ms).

- distância média vs. distância longa: $\mathrm{t}(19)=-5,034 ; \mathrm{p}=0,0001)$, com os tempos de escuta para as longas sendo maiores (282, $86 \mathrm{~ms}$ vs 172,47 ms).

\section{Resumptivas de genitivo em função da distância:}

- distância curta vs. distância média: $\mathrm{t}(20)=-4,022 ; \mathrm{p}=0,001$, com tempos maiores de escuta do segmento crítico para as médias (211,39 ms vs 130,56 ms).

- distância curta vs. distância longa: $\mathrm{t}(20)=-7,597 ; \mathrm{p}=0,0001$, com tempos maiores de escuta para as longas (345,76 ms vs $130,56 \mathrm{~ms})$.

- distância média vs. distância longa: $\mathrm{t}(20)=-4,224 ; \mathrm{p}=0,0004$, com tempos maiores de escuta para as longas (345,76 ms vs 211,39 ms).

Cortadoras de oblíquo em função da distância:

- distância curta vs. distância média: $\mathrm{t}(19)=-2,59 ; \mathrm{p}=0,01$, com tempos maiores de escuta para as médias $(265,12$ vs 212,09).

-distância curta vs. distância longa: $\mathrm{t}(19)=-3,401 ; \mathrm{p}=0,003$, com tempos maiores de escuta para as longas $(282,86$ vs 212,09$)$.

\section{Cortadoras de genitivo em função da distância:}

- distância curta vs. distância média: $\mathfrak{t}(20)=-3,235 ; \mathrm{p}=0,004$, com tempos maiores de escuta para as médias $(289,23$ vs 219,87$)$.

-distância curta vs. distância longa: $\mathrm{t}(20)=-5,602 ; \mathrm{p}=0,0001$, com tempos maiores de escuta para as longas $(401,35$ vs 219,87$)$

- distância média vs. distância longa: $\mathrm{t}(20)=-4,290 ; \mathrm{p}=0,0001$, com tempos maiores de escuta para as longas $(401,35$ vs 289,23$)$. 
Relativas de oblíquo em função do tipo de relativa e distância:

- resumptivas vs cortadoras em distância média: $\mathrm{t}(19)=-4,217 ; \mathrm{p}=0,0001$, com as resumptivas tendo tempos de escuta menores.

\section{Relativas de genitivo em função do tipo de relativa e distância:}

- resumptivas vs cortadoras em distância curta: $\mathrm{t}(20)=-5,557 ; \mathrm{p}=0,0001$, com as resumptivas tendo tempos de escuta menores.

-resumptivas vs cortadoras em distância média: $\mathrm{t}(20)=-2,895 ; \mathrm{p}=0,009$, com as resumptivas tendo tempos de escuta menores.

\subsubsection{4}

\section{Discussão dos resultados}

Os resultados obtidos indicaram efeito principal para o tipo de relativa, com as resumptivas tendo tempos de escuta menores. A expectativa de que a estratégia cortadora seria favorecida em distância curta, quando não há outro fator de custo além do elemento interventor, não se confirmou. Na posição de oblíquo, não houve efeito significativo68 na comparação entre cortadoras e resumptivas em distância curta, mas as médias vão de encontro ao esperado, com as resumptivas tendo tempos menores (172, $47 \mathrm{~ms}$ vs $212,09 \mathrm{~ms}$ ). Nas relativas de genitivo, embora tenha havido diferença significativa entre resumptivas e cortadoras em distância curta, os tempos foram na direção oposta, com as resumptivas sendo processadas mais rápido: 130,56 ms vs. 219,87. Ao que parece, mesmo em distância curta, quando não há fator adicional de custo, a presença de um elemento interventor é fator de custo ao processamento e a presença de um pronome resumptivo parece ser capaz de agilizar o tempo demandado para a recuperação do antecedente, o que é percebido pelos tempos de escuta menores em relação às cortadoras.

A manipulação da distância linear foi fator que afetou o processamento, conforme esperado (ver experimento 3). Com o aumento da distância entre os elementos correferentes, observou-se que o processamento das relativas resumptivas foi mais rápido (ver gráfico 15), sugerindo que em contextos de maior

68 Valor de p encontrado: $\mathrm{p}=0,06$. 
dificuldade, em termos de maior distância linear, o antecedente se encontra menos acessível e pronome resumptivo facilita a resolução da correferência.

A posição sintática como fator isolado não apresentou efeito significativo, contrariando a hipótese de que as genitivas teriam tempos menores, o que pode estar relacionado ao efeito de ilha verificado nessa posição (cf. capítulo 3). As médias de tempo de escuta vão na direção contrária ao esperado, com as de genitivo apresentando tempos maiores que as de oblíquo (265,86 ms vs 240,15 ms). Esse resultado parece indicar que apesar do elemento anafórico e antecedente estarem mais próximos linearmente nas genitivas, o parser encontra dificuldades para estabelecer a relação entre possuído e possuidor. Conforme discutido no experimento 2, nos estímulos experimentais, o tipo de posse utilizado (alienável) e o tipo de relativa manipulado tornam a relação de posse menos nítida e menos explícita, dificultando a integração do antecedente à estrutura de posse estabelecida no interior da relativa, o que pode ter contribuído para as médias de tempos de escuta maiores nas cortadoras. Em outras palavras, na relativa cortadora há uma dificuldade para garantir uma leitura genitiva imediata antes do verbo, sendo, portanto, potencialmente ambígua em relação às demais estratégias.

$\mathrm{Na}$ interação entre posição sintática e tipo de relativa notou-se que o processamento de relativas cortadoras é maior que das resumptivas nas duas posições sintáticas, sendo mais visível para a posição de genitivo, evidenciando a dificuldade de recuperação do antecedente (possuidor) para estabelecer a relação de posse.

É provável que somente no tipo de posse inalienável haja, de fato, uma relação de posse entre o possuidor, que atua como argumento externo do DP possuído (cf. RODRIGUES, 2004). No caso da posse alienável, em que não há essa relação argumental, o processador encontra dificuldades em integrar o antecedente à posição argumental correspondente. Nesse caso, o pronome resumptivo ajudaria o parser a indicar a posição na qual o antecedente deve ser integrando, tornando o processamento mais fácil.

Em relação à variável distância linear, presença do pronome resumptivo parece, pois, facilitar a associação entre os nomes correferentes, já que em distância curta e média o processamento foi mais rápido em relação às cortadoras. Em distância longa, embora não tenha sido observada diferença significativa entre os dois tipos de elementos anafóricos, as médias dos tempos de escuta vão na direção 
esperada, com os resumptivos apresentando tempos menores: $345,76 \mathrm{~ms}$ vs 401,35 ms.

Na posição de oblíquo, o pronome resumptivo favorece o processamento em distância média. Em distância curta, apesar da ausência de resultado significativo, as médias apontam para um favorecimento da estratégia resumptiva $(172,47 \mathrm{~ms})$ em comparação à cortadora (212,09 ms). Em distância longa, as médias dos tempos de escuta mostraram a tendência de o processamento das cortadoras ser mais rápido (282,86 ms) do que as resumptivas (318,94 ms), o que está ao contrário do esperado, já que nesse contexto, há, além do efeito de intervenção, dois adjuntos que distanciam o elemento anafórico do seu antecedente, o que tornaria o processamento mais difícil. Esse resultado em sentido contrário ao esperado carece de uma análise mais detalhada e pode ter se dado pelo comportamento individual de alguns participantes que contribuíram para elevar a média de tempo de escuta de resumptivas de todo o grupo69.

\subsubsection{5}

\section{Análise dos tempos de reação para todas as posições sintáticas}

Partindo da hipótese de que a presença dos pronomes resumptivos dirime o custo de processamento em contextos onde há mais efeito de intervenção, comparamos as médias dos tempos de escuta do segmento crítico de todas as posições sintáticas em conjunto. Com base nos resultados dos experimentos 3 e 4, prevê-se a seguinte hierarquia em termos da menor para a maior dificuldade de processamento: sujeito < objeto direto< oblíquo / genitivo.

Nesta seção, contrastamos o tempo de processamento de todas as posições sintáticas em conjunto, analisando, no entanto, somente as relativas que apresentam pronome resumptivo. Isto porque a lacuna é de natureza diferente nas relativas contrastadas no experimento 3 (sujeito e objeto direto) e no 4 (oblíquo e genitivo). Nas relativas de sujeito, a lacuna corresponde a um vestígio resultante de movimento, caracterizando a estratégia padrão. Nas de objeto direto, a lacuna também corresponde a um vestígio, conforme discutimos no capítulo 3. Já no experimento 4 , a lacuna é resultado de apagamento, correspondendo à estratégia 
cortadora. Assim, nos deteremos em apresentar as análises relevantes somente para as estruturas com pronome resumptivo.

A análise da variância revelou efeito significativo para a posição sintática, $\mathrm{F}$ $(1,83)=5,287 ; p=0,02$. O gráfico abaixo mostra que, de fato, as relativas de sujeito têm processamento mais rápido em relação às demais posições:

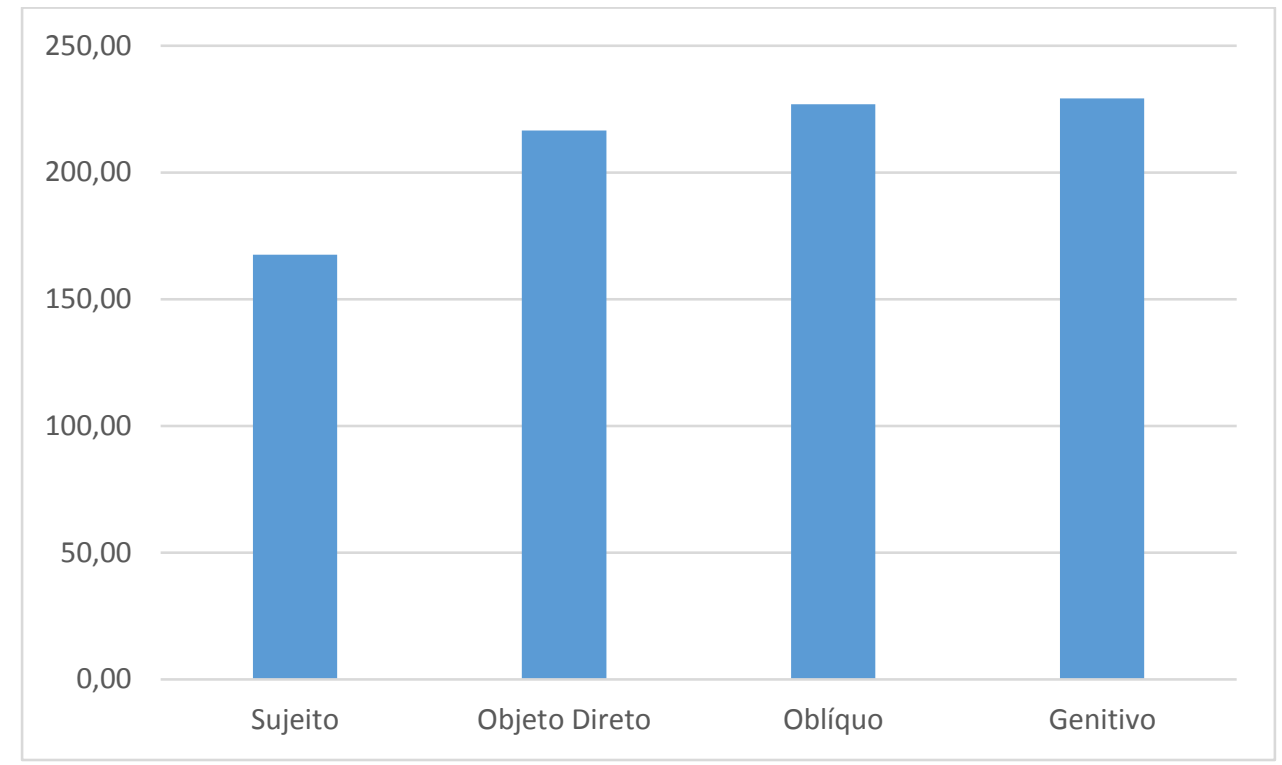

Gráfico 16: Médias dos tempos de escuta do segmento crítico em função da posição sintática- experimentos 3 e 4

A distância linear também foi fator atuante no processamento, quando comparadas todas as posições: $\mathrm{F}(1,83)=118,79 ; \mathrm{p}=0,0001$. $\mathrm{O}$ gráfico 17 mostra um aumento no tempo de escuta à medida que a distância é maior: 


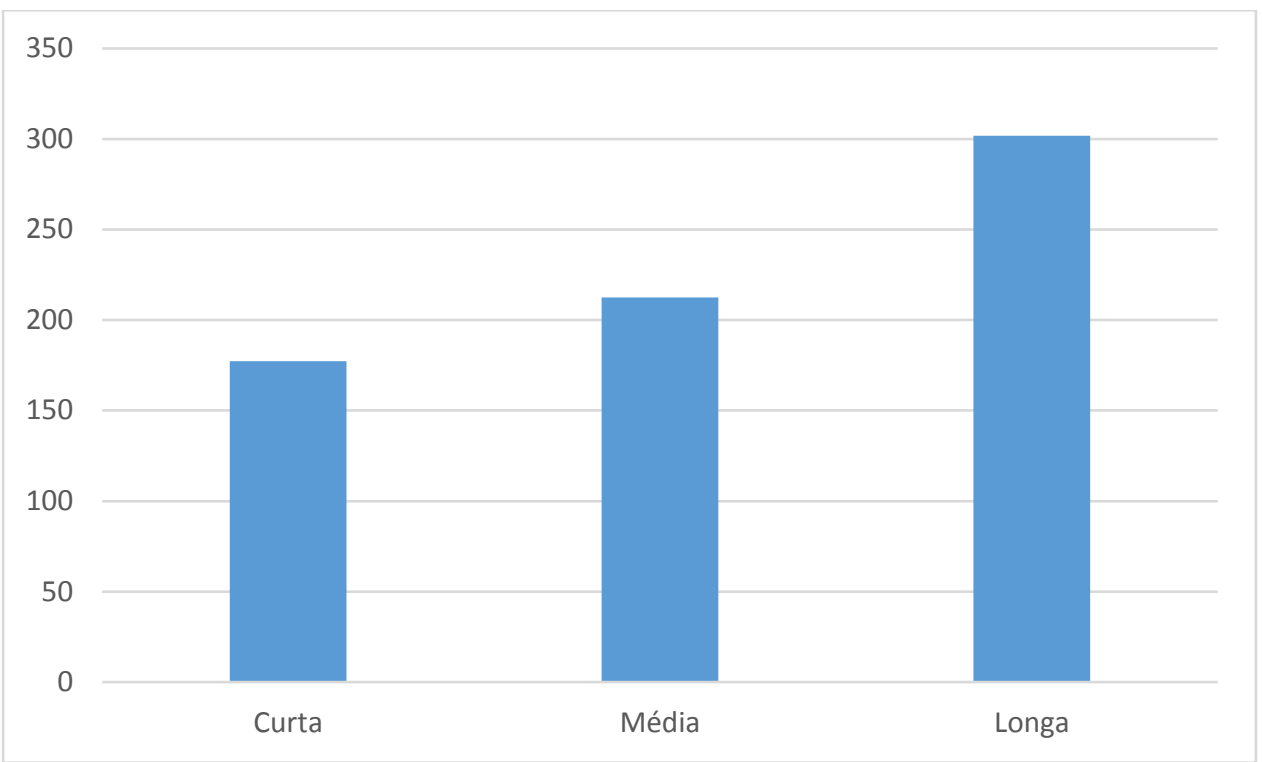

Gráfico 17: Médias dos tempos de escuta do segmento crítico em função da distância linear - experimentos 3 e 4

A interação entre posição sintática e distância linear também foi significativa: $F(1,83)=12,297 ; p=0,0001$. O gráfico abaixo apresenta as médias obtidas:

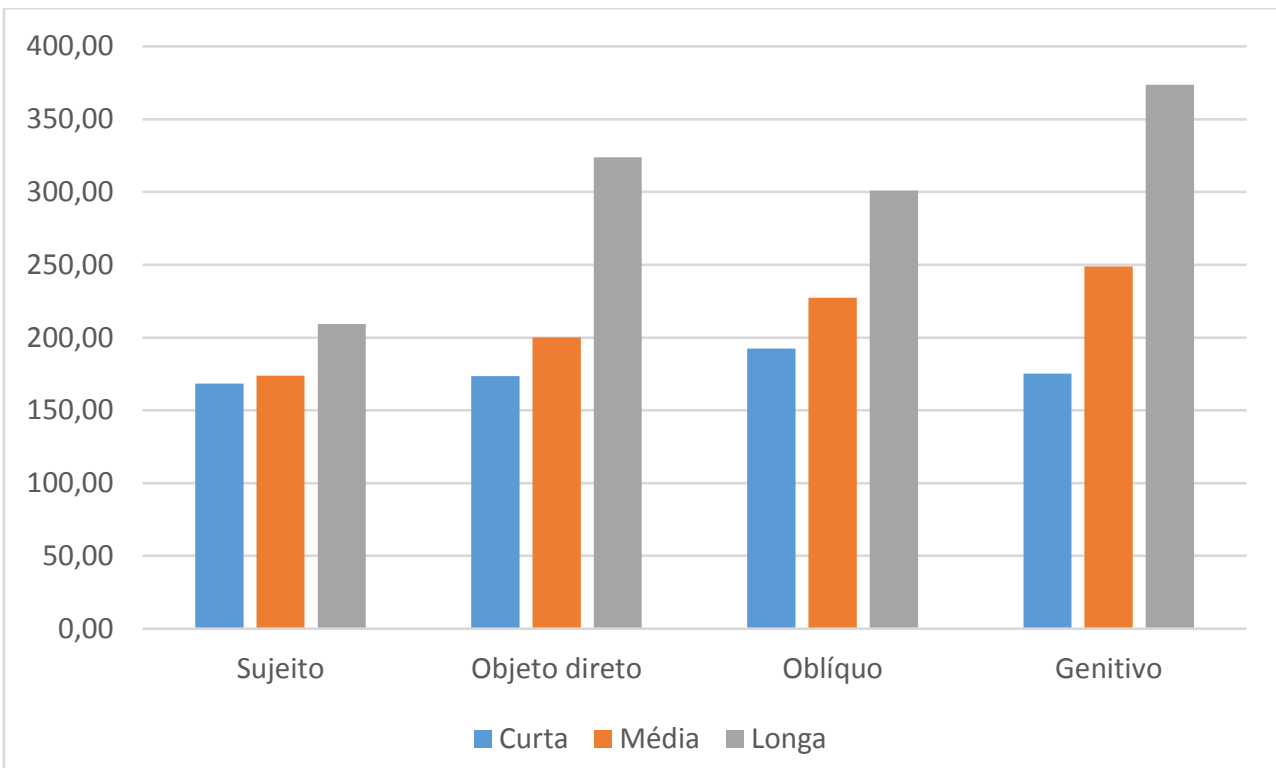

Gráfico 18: Médias dos tempos de escuta do segmento crítico em função da posição sintática e distância linear-experimentos 3 e 4

Apreende-se do gráfico 17 que em todas as posições, há um incremento no tempo de processamento à medida que a distância linear aumenta. Nas posições mais encaixadas, em que há sempre elemento interventor - o fator distância tem 
uma influência mais expressiva. Observa-se que nessas posições mais complexas, e principalmente nas de genitivo, há uma maior diferença no tempo de processamento entre distâncias curtas, médias e longas, se comparadas as de sujeito.

Foram feitos alguns contrastes entre pares e as diferenças que foram significativas estão apresentadas de forma sintética a seguir. Cabe ressaltar que não vão ser reportados aqui, novamente, as comparações par a par já feitas separadamente para cada experimento70:

Resumptivas de sujeito $\mathbf{x}$ genitivo: $\mathrm{t}(43)=-3,43 ; \mathrm{p}=0,002$, com as de sujeito tendo tempo de escuta menor (229,24 ms vs $167,51 \mathrm{~ms})$.

Resumptivas de sujeito x oblíquo: $t(43)=-3,40 ; p=0,01$, com as de sujeito apresentando tempo de escuta menor (226,95 ms vs 167,51$)$.

Na próxima seção, discutiremos esses resultados à luz das teorias sobre processamento apresentadas no capítulo 4.

\subsubsection{6 \\ Discussão geral dos experimentos}

Os dois experimentos de escuta automonitorada conduzidos indicam que o fator distância exerce um papel determinante no processamento de relativas, tornando-as mais custosas. Em distâncias longas, para as posições de oblíquo e genitivo, em que o antecedente está menos acessível, a presença do pronome resumptivo parece exercer papel de facilitador do processamento ao recuperar o antecedente. Esses dados estão de acordo com o princípio da acessibilidade de Ariel (1990) e também com os dados de Mollica (2003). As autoras argumentam, sob enfoques teóricos distintos, em favor dessa associação entre aumento da distância e favorecimento da estratégia resumptiva. Mesmo em posição de sujeito, os resumptivos são favorecidos em detrimento da lacuna quando estão linearmente distante de seu antecedente, o que também está de acordo com os dados de fala de Mollica (2003). O mesmo é observado para as de objeto direto, em que a estratégia resumptiva facilita o processamento em distância longa.

70 Os contrastes envolvendo sujeito x objeto direto e oblíquo x genitivo já foram reportados nas seções anteriores. 
Cabe ressaltar que, embora a literatura defenda que a ocorrência de resumptivos é favorecida quando o antecedente é indefinido (KATO E NUNES, 2009; MOLLICA, 1997; TARALLO, 1983), do ponto de vista da compreensão, a ocorrência de um antecedente definido, como foi o caso dos estímulos utilizados neste experimento, não parece ter sido relevante ao parser, já que em nenhum contraste efetuado a lacuna teve tempo de processamento menor.

$\mathrm{Na}$ comparação entre os tempos de escuta de todas as relativas resumptivas, observa-se uma clara diferença no processamento de relativas de sujeito e das demais posições. Corroborando a extensa literatura já reportada (cf. capítulo 4), relativas de sujeito são processadas mais rápido. Em todas as demais posições, que apresentam elemento interveniente, os tempos de escuta são bem próximos e não diferentes estatisticamente: OD: 216,51 ms; OBL: 226,95 ms; GEN: 229,24 ms. Diante de tais resultados, é possível apresentar a seguinte ordem (crescente) de dificuldade de processamento para as relativas resumptivas: $\mathrm{SUJ}<\mathrm{OD} / \mathrm{OBL} / \mathrm{GEN}$. Essa hierarquia ilustra a facilidade de processamento da posição de sujeito, em que não há efeito de intervenção, para as demais, em que há sempre um DP intervindo.

Em suma, os experimentos 3 e 4 apresentados nesta seção apresentam evidências de que fatores como distância linear e posição sintática ocupada pelo elemento anafórico impõem custo à compreensão de orações relativas, na medida em que podem tornar a recuperação do antecedente mais difícil. A presença do pronome resumptivo parece amenizar esse custo, facilitando a retomada do antecedente. Mesmo quando o pronome não parece tornar o processamento mais eficiente, sua presença parece não causar estranhamento ao processador linguístico.

\section{4}

\section{Em síntese}

Os experimentos conduzidos tiveram como objetivo investigar possíveis variáveis que afetam a compreensão de orações relativas. Os dois primeiros experimentos avaliaram, por meio de uma tarefa offline a percepção dos participantes acerca das diferentes estratégias de relativização do PB em função da posição sintática ocupada pelo elemento anafórico. No terceiro e quarto, avaliou-se a influência de possíveis fatores de custo no processamento de relativas através de 
uma tarefa online. Percebe-se, portanto, que cada conjunto de experimento buscou avaliar aspectos distintos associados ao processamento dos resumptivos.

$\mathrm{Na}$ tarefa de julgamento de aceitabilidade, que capta um momento pós processamento, relativas resumptivas foram julgadas piores que as cortadoras e padrão. Observou-se claramente julgamentos bem definidos para a posição de sujeito, que teve alta rejeição aos pronomes. Nas demais posições, em que havia maior complexidade, houve uma distribuição mais uniforme nos demais valores da escala. Além disso, não se verificou diferença entre resumptivas e cortadoras, o que não está de acordo com o pressuposto teórico de que essas seriam mais econômicas e, portanto, mais aceitas. Notou-se, contudo, que as cortadoras tiveram percentual de aceitação ligeiramente maior que as resumptivas (52,19\% vs 44,78\%)71, conforme visto na subseção 5.2.4. .

Os experimentos de escuta automonitorada (3 e 4) apresentaram medidas em tempo real (online). Os resumptivos não foram desfavorecidos em nenhum contexto. Ao contrário, nas posições encaixadas, tornam o processamento mais fácil em relação às cortadoras, sendo privilegiados quando há distância linear entre os elementos correferentes.

Se por um lado, os resumptivos receberam julgamentos baixos na posição de sujeito (experimento 1), no curso do processamento, esses elementos foram tratados de forma indistinta pelo processador em distância curta e média. Em distância longa, tornaram mais rápido o processamento.

A posição de objeto direto foi a que mais aceitou resumptivos na tarefa de julgamento de aceitabilidade, sendo essa aceitação significativamente maior em relação à posição de sujeito. No experimento online, relativas de objeto direto foram mais difíceis de serem processadas em relação às de sujeito. A maior aceitação de resumptivos por um lado e tempos de escuta maiores, por outro, sugerem que, de fato, o efeito de intervenção traz implicações de custo para posição de objeto direto.

Em relação às posições que envolvem um sintagma preposicionado e de genitivo, observou-se que, apesar de terem recebido julgamentos inferiores à forma padrão e não ter havido diferença em comparação à cortadora, os resumptivos não foram totalmente rejeitados. Especificamente em relação à posição de genitivo não houve diferença entre os julgamentos de cortadoras e resumptivas. Porém, no que

71 Percentual obtido a partir da média percentual de notas 3 e 4 para relativas resumptivas $\mathrm{x}$ cortadoras. 
tange ao processamento, a forma pronominal tornou o processamento mais rápido, sugerindo um papel facilitador dos resumptivos no momento de compreensão da sentença.

$\mathrm{Na}$ comparação entre relativas resumptivas para todas as posições investigadas, observa-se que, tanto os experimentos de julgamento de aceitabilidade, quanto os de escuta automonitorada, apresentam resultados na mesma direção: uma clara diferença entre a posição de sujeito, em que antecedente e elemento anafórico estão linearmente próximos e as demais (OD, Oblíquo, OPrep, Genitivo), que têm em comum um elemento interventor.

Dessa forma, foi possível notar que no momento do processamento, mais automático e menos consciente, a presença do resumptivo é, em alguns contextos, indiferente ao processador. Em outros, serve como meio de compensar o alto custo envolvido na recuperação e integração do antecedente. Após o processamento, no entanto, quando o participante deve avaliar, sem pressão de tempo, os resumptivos, esses elementos parecem gerar certo incômodo, o que resulta em julgamentos menos claros. Apesar disso, em conjunto, os experimentos indicam uma forte influência do efeito intervenção no custo das relativas. 


\section{6}

\section{Considerações finais}

Esta tese teve como objetivo investigar a compreensão de orações relativas com pronomes resumptivos no $\mathrm{PB}$, buscando avaliar possíveis fatores associados ao custo computacional e de processamento dessas estruturas, com foco particular em relativas com pronome resumptivo, elemento que tem sido associado na teoria linguística a uma estratégia de último recurso.

Investigam-se três possibilidades de relativização: a estratégia padrão (canônica) e as não-padrão, cortadora e resumptiva. Buscou-se neste trabalho prover uma caracterização dos tipos de custo implicados, por um lado, na derivação e na representação dessas estruturas nas interfaces, nos termos do que tem sido considerado em análises linguísticas de orientação gerativista e, por outro, no processamento on-line dos diferentes tipos de relativas, a partir de resultados de estudos conduzidos na área da Psicolinguística. Foi proposto no capítulo 3 que as estratégias de relativização impactam em custo computacional. No caso das relativas padrão, esse custo deve-se, entre outros fatores, à operação de movimento, mas, a depender do tipo de relativa é necessário considerar também custos específicos no próprio processo derivacional e também nas interfaces. Para explicar custo associado às relativas de objeto direto, tem-se proposto que este está associado à presença de um elemento interveniente, no caso, o DP sujeito da relativa (caraterizado a partir da hipótese de intervenção por Friedmann, Belletti e Rizzi, 2009); para as relativas padrão preposicionadas, o custo está ligado ao carregamento de mais traços (pied-piping do elemento QU- e da preposição). Nesse contexto, as estratégias cortadoras e resumptivas podem ser vistas como alternativas de último recurso, aplicados quando há algum tipo de violação nas interfaces. No caso das posições preposicionadas, a utilização da cortadora é a mais econômica, pois evita o pied-pipping da preposição, já que nesse caso move-se apenas o pronome relativo e depois faz-se o apagamento da preposição encalhada em PF. A resumptiva, por sua vez, apresenta custo tanto para PF quanto para LF e, segundo as análises linguísticas, é utilizada para salvar derivações (por exemplo, efeitos de ilha). No caso do $\mathrm{PB}$, os pronomes resumptivos são obrigatórios nas relativas em que não há apagamento da preposição encalhada. 
No campo do processamento, como vimos no capítulo 4, tem-se buscado caracterizar os fatores que podem impactar a produção/compreensão dessas estruturas, tanto na área de aquisição quanto nos estudos sobre processamento adulto. A questão da assimetria entre relativas de sujeito e de objeto tem sido um fenômeno bastante estudado. Resultados de estudos em produção têm mostrado que os participantes se esquivam de utilizar as relativas de objeto, optando por outras mais simples. Na compreensão, por sua vez, essas relativas também impõem dificuldades ao processamento, apresentando-se mais custosas do que as de sujeito, em que não há elemento interveniente entre a posição de origem e antecedente (GIBSON, 1998; 2000; GORDON et al., 2001). Diante disso, é possível pensar, no caso do PB, qual seria o papel do pronome resumptivo. Partindo das considerações de Ariel (1999) sobre fatores que tornam o antecedente da relativa menos acessível, é possível dizer que a aplicação da estratégia resumptiva está associada a contextos específicos, de alta demanda, relacionados, por exemplo, à distância (linear/hierárquica) do antecedente, à posição sintática ocupada, à natureza e características semânticas do antecedente, ao grau de encaixamento da oração relativa e etc.

O conjunto de experimentos reportados nesta tese investigou a interferência desses fatores de custo no processamento de orações relativas, confrontando as três possíveis estratégias de relativização no PB. Nos dois primeiros, analisamos a aceitabilidade dos diferentes tipos de relativa em função da posição sintática do pronome/lacuna. Contrastamos a aceitabilidade de relativas de sujeito em relação a outras posições mais complexas. Apesar de o PB ser relativamente flexível quanto ao licenciamento de pronomes resumptivos, essa é a estratégia minoritária em PB72.

Os resultados dos dois testes de aceitabilidade mostraram que, mesmo nos ambientes de maior complexidade estrutural e de processamento, como nas posições de objeto preposicionado e de genitivo, a estratégia padrão foi a preferida. Dentre as posições examinadas, a de sujeito foi a mais aceita na condição padrão e a mais recusada na estratégia resumptiva. $\mathrm{Na}$ estratégia padrão, na comparação entre pares, em que confrontamos a aceitabilidade do pronome em posições mais complexas- objeto direto, objeto preposicionado e genitivo-, observou-se maior aceitação das relativas de objeto direto, enquanto que não houve diferença na

72 Dados diacrônicos observaram, contudo, um incremento dessa estratégia em posições mais baixas e até mesmo na de sujeito (cf. capítulo 2). 
aceitação das relativas preposicionadas e genitivas. A preferência pela estratégia padrão nessas posições pode ser explicada pelo perfil de público investigado, que está inserido em ambiente acadêmico, marcado pela cultura escrita, normativa e formal.

Em relação aos experimentos de compreensão online, foi possível notar que os pronomes resumptivos facilitam o processamento em contextos de maior complexidade, como os envolvendo efeito de intervenção e maior distância entre os elementos da referência. Na posição de objeto direto, o resumptivo torna o processamento mais fácil em distância longa e até mesmo em distância curta. Em distância média, embora não tenha sido observado efeito significativo, as médias foram na direção esperada, com tempos de escuta menores para relativas resumptivas. Nesse caso, a complexidade processual gerada pela presença do DP interveniente é amenizada pelo pronome. Nas relativas de oblíquo e de genitivo, o processamento de resumptivas é mais rápido que das cortadoras, sendo ainda mais favorecido quando há aumento da distância.

Na posição de sujeito, que, de acordo com a teoria linguística (cap. 3) e com a literatura em processamento (cap. 4), não favorece a estratégia resumptiva, tempos menores foram associados à presença de pronomes em distância longa, o que está de acordo com os dados de fala analisados por Mollica (2003).

Cada grupo de experimento (tarefa off-line - julgamento de gramaticalidade; tarefa online - escuta automonitorada) captura aspectos diferentes relativos ao modo como os falantes lidam com os resumptivos no âmbito do conhecimento virtual (avaliação da aceitabilidade vs no processamento online (escuta automonitorada).

A tarefa de julgamento de aceitabilidade, feita sem pressão de tempo, mede a percepção dos falantes acerca de uma estrutura em um momento pósprocessamento. É, portanto, uma avaliação menos automática. A escuta automonitorada, ao contrário, capta o processamento em tempo real, mais automatizado e incremental. Nesse sentido, foi importante contrastar a compreensão das relativas resumptivas em tarefas distintas: julgamento de aceitabilidade (tarefa off-line) e escuta automonitorada (processamento online). A esse respeito, os resultados sinalizam que, apesar do estranhamento causado pela estrutura resumptiva na tarefa de julgamento, no curso do processamento, a ocorrência de uma forma pronominal não compromete o parsing. Resultado semelhante foi encontrado por Hofmeister e Norcliffe (2013), que também 
verificaram uma diferença entre dados offline e online, indicando uma disjunção entre o que o falante entende como sendo aceitável em sua língua e o que, de fato, se passa no momento de processamento.

A assimetria observada no comportamento dos resumptivos nos dois sistemas (gramática e processamento) parece indicar que o parser não apresenta a mesma sensibilidade às restrições identificadas para a Gramática. Isso porque, os pronomes resmptivos parecem tornar a compreensão mais rápida em contextos de custo (efeito de intervenção, distância, acessibilidade do antecedente), embora sejam pior avaliados em tarefa offline. Mesmo quando não há fator de custo (como é o caso das relativas de sujeito em distância curta), o parser parece não identificar a restrição gramatical associada à estrutura, já que, como vimos, os tempos de escuta de resumptivas não foram maiores que das lacunas.

Assim, toda a discussão apresentada nesta tese e, em especial, os experimentos conduzidos no capítulo 5 , fomentam uma discussão acerca da possível distinção entre o resumptivo na Gramática e o resumptivo no processamento, ao sugerir que o papel desempenhado pelo pronome é diferente nos dois sistemas.

Diante de tais evidências, outras questões de pesquisa surgem e podem vir a ser objeto de investigação futura. Sugere-se submeter as mesmas sentenças utilizadas nos experimentos online a um teste de julgamento de aceitabilidade, para verificar se a manipulação da distância linear apresenta algum efeito na avaliação dos participantes. Ainda, seria importante avaliar efeito de distância estrutural em contraste com distância linear no uso do resumptivo/lacuna, de modo análogo ao trabalho de Hofmeister e Norcliffe (2013). Neste caso, seria possível confrontar a aceitabilidade/processamento de relativas resumptivas envolvendo distância linear, como as investigadas no experimento 3 e 4, com outras envolvendo distância estrutural (hierárquica): “A garota confirmou que havia um prisioneiro que os policiais ajudaram (ele) a fugir".

Considera-se interessante, ainda, avaliar se os pronomes resumptivos facilitam a recuperação do antecedente, em casos onde há DPs de gêneros congruentes (ex: "O aluno que o professor encontrou ele...”), em comparação a sentenças em que os gêneros são diferentes (ex: “O aluno que a professora encontrou ele...). Outra questão de pesquisa é avaliar se de fato os resumptivos são mais empregados quando o antecedente corresponde a um DP indefinido, por meio 
do contraste com DPs definidosem diferentes posições sintáticas: "Eu encontrei uma atriz que ela é muito bonita pessoalmente" vs "Eu encontrei a atriz que ela é muito bonita pessoalmente". Outra questão instigante é avaliar se há, nas relativas de genitivo, alguma associação entre o tipo de posse (alienável ou inalienável) e o tipo de relativa (cortadora e resumptiva) empregado.

Enfim, ainda permanecem em aberto várias questões relacionadas ao processamento de orações relativas resumptivas no $\mathrm{PB}$, constituindo-se como um objeto intrigante com muitas possibilidades de investigação. Pretendemos, assim, incentivar novas pesquisas a serem desenvolvidos. 


\section{Referências bibliográficas}

ABNEY, S.P. The English noun phrase in its sentential aspect. MIT, 1987.

ACKERMAN, L.; FRAZIER, M.; YOSHIDA, M. Remarks and replies: resumptive pronouns can ameliorate illicit island extractions. Linguistic Inquiry, v. 49, n. 4, p. 847-859, 2018.

ALEXANDRE, N. A. Estratégia resumptiva em relativas restritivas do português europeu. Lisboa, 2000. 228 p. Dissertação de Mestrado. Faculdade de Letras, Universidade de Lisboa.

ALEXANDRE, N.; HAGEMEIJER, T. Estratégias de relativização de PPs no mundo luso-atlântico: crioulos de base lexical portuguesa e variedades do português. In: MOURA, D. e SIBALDO, M. (Eds). Para a História do Português Brasileiro - Volume III: Estudos Comparativos entre o Português Brasileiro e Língua Crioulas de Base Lexical Portuguesa. Maceió: EDUFAL, 2013, p. 49-71.

ALEXOPOULOU, T.; KELLER, F. Linguistic complexity, locality, and resumption. In: WCCFL, 22, 2003. Proceedings of WCCFL 22. Somerville, MA: Cascadilla Press, p.15-28, 2003.

Locality, cyclicity and resumption: at the interface between the grammar and the human sentence processor. Language, v. 83, n.1, p. 110-160, 2007.

ALEXPOULOU, T. Truly intrusive: Resumptive pronominals in questions and relative clauses. Lingua, v. 120, p.485-505,2010.

AOUN, J. Resumption .and last resort. D.E.L.T.A., v. 16, p.13-43, 2000.

AOUN, J.; CHOUEIRI, L.; HORNSTEIN, N. Resumption, Movement, and Derivational Economy. Linguistic Inquiry, v .32, n .2, p. 371-403, 2001.

ARIEL, M. Cognitive universals and linguistic conventions: the case of resumptive pronouns. Studies in Language, v. 23, n. 2, p. 217-269, 1999.

BELTRAMA, A.; XIANG, M. Intrusive resumptives as processing facilitators: An experimental investigation. In: IYER, J.; KUSMER, L. (Eds). In: Annual Meeting of the North East Linguistic Society, 44. Proceedings of the 44th Annual Meeting of the North East Linguistic Society, p. 41-54, 2014.

Unacceptable but comprehensible: the facilitation effect of resumptive pronouns. Glossa: a journal of general linguistics, v. 1, n. 29, p. 1-24, 2016.

BHATT, R. The raising analysis of relative clauses: evidence from adjectival modification. Natural Language Semantics, v. 10, n. 1, p. 43-90, 2002. 
BIANCHI, V. Headed Relative Clauses in Generative Grammar - Part 1. Glot International, v. 6, n. 7, p. 197-204, 2002 a.

Headed Relative Clauses in Generative Grammar - Part 2. Glot International, v. 6, n. 8, p. 235-247, 2002 b.

BLAUBERGS, M. S.; BRAINE, M. D. Short-term memory limitations on decoding self-embedded sentences. Journal of Experimental Psychology, v. 102, n .4, p. 745-748, 1974.

CHÁCON, D. Comparative Psychosyntax. Maryland, 2015. 240 p. Tese de Doutorado. Faculty of the Graduate School. University of Maryland.

CHÁCON, D.; LAKHANI, N. Resumptive pronouns affect later filler-gap dependency processing. Proceedings of NELS 47. Amherst, MA: 2016

CHOMSKY, N. Aspects of theory of syntax. Cambridge, MA: MIT Press, 1965.

On Wh-Movement. In: CULICOVER, P.; WASOW, T.; AKMAJIAN, A. (Eds.). Formal Syntax. New York: Academic Press, 1977, p. 71-132.

15,1980 .

Rules and representations. Behavioral and Brain Sciences, v.3, n.1, p.1-

Lectures on Government and Binding. Dordretch, 1981.

. Some concepts and consequences of the Theory of Government and Biding. Cambridge, MA: The MIT Press, 1982.

Barriers. Cambdrige: The MIT Press, 1986.

The Minimalist Program. Cambridge: The MIT Press, 1995.

Minimalist inquiries: the framework. In: Martin, R.; Michaels, D.; Uriagereka, J. (Orgs.). Step by step. Essays on minimalist syntax in honor of Howard Lasnik. Cambridge, MA: MIT Press, 2000, p. 89-155.

Derivation by phase. In: KENSTOWICZ, M.; HALE, K. (Eds.). A life in language. Cambridge, MA: MIT Press, 2001, p. 1-52.

On phases. In: FREIDIN, R.; OTERO, C. P.; ZUBIZARRETA, M. L. (Eds). Foundational issues in linguistic theory: essays in honor of Jean-Roger Vergnaud. Cambridge, MA: MIT Press, 2008, p. 133-166.

CHOMSKY, N.; MILLER, G. A. Introduction to the formal analysis of natural languages. In: DUNCAN, L. R.; BUSH, R. R.; GALANTER, E. (Eds.). Handbook of Mathematical Psychology. New York: Wiley, v .2, 1963, p. 269321. 
Finitary models of language users. In: DUNCAN, L. R.; BUSH, R. R.; GALANTER, E. (Eds.). Handbook of Mathematical Psychology. New York: Wiley, v .2, 1963, p. 269-321.

CABRAL, A.; LEITÃO, M.; KENEDY, E. A influência da animacidade no processamento de cláusulas relativas no Português Brasileiro. Letras de Hoje, v. $59, \mathrm{n} .1,2015$.

CAMACHO, R.G. Construções relativas nas variedades do português: uma interpretação discursivo-funcional. Filologia Linguística, v .15, n .1, p.179-214, 2013.

CORRÊA, V. Oração Relativa: o que se fala e o que se aprende no Português do Brasil. Campinas, 1998. 165 p. Tese de Doutorado. Instituo de Estudos da Linguagem. Universidade de Campinas.

CORRÊA, L. M. S.; AUGUSTO, M. R. A..; MARCILESE, M. Competing analyses and differential cost in the production of non-subject relative clauses. Glossa: a journal of general linguistics 3, v. 62, n. 1, p. 1-22, 2018.

CORRÊA, L. M. S.; AUGUSTO, M.R.A.; LONGCHAMPS, J.; FORSTER, R. Referência Anafórica com relativas restritivas de objeto: custo relativizado na interface gramática-pragmática. Revista Linguística, v .8, n. 2, p. 173-195, 2012.

CORRÊA, L. M. S.; AUGUSTO, M.R.A.; MIRANDA, F. V.; MARCILESE, M. Avoiding processing cost: differential strategies in the production of restrictive clauses. In: AMLap, 14, Cambridge. Abstracts. Cambridge, p.47, 2008.

CORRÊA, L. M. S. An Alternative Assessment of Children's Comprehension of Relative Clauses. Journal of Psycholinguistic Research, v .24, n .3, 1995.

Relação entre sintaxe experimental - psicolinguística experimental para além da metodologia. Revista da ABRALIN, v .13, n .2, p.21-54, 2014.

COSTA, J.; LOBO, M. Subject-object asymmetries in the acquisition of Portuguese relative clauses: adults vs children. Lingua, p.1083-1100, 2011.

COSTA, J. et al. The acquisition of PP relatives in Hebrew and European Portuguese: another window into the atoms of intervention. Language Acquisition and Development: Proceedings of GALA 2013, p.35-48, 2015.

CYRINO, S. M. L. O objeto nulo no Português do Brasil: um estudo sintáticodiacrônico. Campinas, 1994. 229 p. Tese de Doutorado. Campinas: Universidade de Campinas.

ENOCHSON, K.; CULBERSTON, J. Collecting Psycholinguistic Response Time Data Using Amazon Mechanical Turk. PLoS One, n. 10, v. 3, p. 1-17, 2015.

FRAZIER, L.; D'ARCAIS, G. Filler driven parsing: a study of gap filling in Dutch. Journal of Memory and Language, v .28, n .3, p.331-344, 1989. 
FERREIRA, F.; SWETS, B. The production .and comprehension of resumptive pronouns in relative clause" island" contexts. In: CUTLER, A. (Ed.). Twenty-first Century Psycholinguistics, 2005, p. 263-278.

FOSS, D. J.; LYNCH, R. H. Decision processes during sentence comprehension: effects of surface structure on decision times. Perception and Psychophysics, $\mathrm{n} .5$, p.145-148, 1969.

FRIEDMANN, N.; BELLETTI, A.; RIZZI, L. Relativized relatives: Types of intervention in the acquisition of A-bar dependencies. Lingua, v .119, p.67-88, 2009.

GAGNON, M.; MITROVIC, I. More evidence for the split analysis of relative clauses. Proceedings of the $\mathbf{2 0 1 2}$ annual conference of the Canadian Linguistics Association, p.1-15,2012.

GIBSON, E., e PEARLMUTTER, N. Constraints on sentence comprehension. Trends in Cognitive Science, p. 262-268, 1998.

GIBSON, E. Linguistic Complexity: locality of syntactic dependencies. Cognition, p. 1-76, 1998.

The Dependency Locality Theory: A Distance-Based Theory of Linguistic Complexity. In: MARANTZ, A.; MIYASHITA, Y. e O'NEIL, W. (Eds.). Image, language, brain: papers from the first mind articulation project symposium, Cambridge, Cambridge: MIT Press, 2000, p. 95-126.

GIBSON, E.; et al. Reading relative clauses in English. Cognitive Linguistics, p. 313-353, 2005.

GOUVÊA, A.C. Processing syntactic complexity: Cross-linguistic differences and ERP evidence. Maryland, 2003. Tese de Doutorado. University of Maryland.

- Complexidade sintática: o processamento de orações relativas em português brasileiro e em inglês. In: MAIA, M. e FINGER, I. (Orgs.). Processamento da linguagem. Pelotas: Educat, 2005, p.201 - 222.

GORDON, P.; HENDRICK, R.; JOHNSON, M. Memory interference during language processing. Journal of Experimental Psychology: Learning, Memory, and Cognition 27, p. 1411-23, 2001.

GORDON, P. C.; HENDRICK, R.; JOHNSON, M. Effects of noun phrase type on sentence complexity. Journal of Memory and Language, v .51, n.6, p. 14111423, 2004.

GORDON, P. C. et al. Similarity-Based Interference During Language Comprehension: evidence from Eye Tracking During Reading. Journal of Experimental Psychology: Learning, Memory, and Cognition, v .32, n. 6, p. 13041321, 2006. 
GRILLO, N. Generalized minimality: feature impoverishment and comprehension deficits in agrammatism. Lingua, v. 119, p. 1426-1443, 2009.

GROLLA, E. A aquisição da periferia esquerda da sentença em Português Brasileiro. Campinas, 2000. 106 p. Dissertação de Mestrado. Instituto de Estudos da Linguagem, Universidade Estadual de Campinas.

Resumptive pronouns as last resource: implications for language acquisition. U. Penn Working Papers in Linguistics, v .11, n .1, p. 71-83, 2005 a.

Pronomes resumptivos em português brasileiro adulto e infantil. D.E.L.T.A. Documentação de Estudos em Linguística Teórica e Aplicada (PUC-SP. Impresso), v. 21:2, p. 167-182, 2005 b.

Pronouns as elswhere elements: implications for language acquisiton. Connecticut, 2005 c. 203 p. Tese de Doutorado. University of Connecticut.

GROLlA, E.; AUGUSTO, M. R. A. Pronomes resumptivos em português brasileiro infantil: dados de produção e compreensão. Cadernos de Letras da UFF - Dossiê: Anáfora e correferência: temas, teorias e métodos, nº 49, p. 133-154, 2014.

Absolutive Constructions in Brazilian Portuguese and Relativized minimality effects in children's productions. Proceedings of Generative Approaches to Language Acquisition, p.36-47, 2016.

HAN, C.; et al. Processing strategies and resumptive pronouns in English. Proceedings of the $30^{\text {th }}$ Wes Coast Conference on Formal Linguistics, p.153$261,2012$.

HAUSER, M.; CHOMSKY, N.; FITCH, W. T. The Faculty of language: what is it, who has it, and how did it evolve?. Science, n. 298, p. $1569-1579,2002$.

HAWKINS, J. Processing complexity and filler-gap dependencies across grammars. Language, v. 75, p. 244-285, 1999.

Efficiency and complexity in grammars. In: SONG, J. (Ed.). The Oxford Handbook of Linguistic Typology. Cambridge: Oxford University Press, p. 121$152,2004$.

HEESTAND, D., XIANG, M.; POLINSKY, M. Resumption still does not rescue islands. Linguistic Inquiry, n. 42, v .1, p. 138-152, 2011.

HOFMEISTER, P.; NORCLIFFE, E.2013. Does resumption facilitate sentence comprehension? Disponível em: http://crl.ucsd.edu/ phofmeister/resumptionhofmeisterenorcliffe-rev1.pdf. Acesso em: 15 de junho de 2015.

HOLMES, V.M.; O'REGAN, J.K. Eye fixation patterns during the reading of relative-clause sentences. Journal of Verbal Learning \& Verbal Behavior, v.20, n.4, p.417-430, 1981. 
HORNSTEIN, N. Move! A minimalist theory of construal. Malden/Oxford: Blackwell, 2001.

Pronouns in minimal setting. In: COVER, N. e NUNES, J. (Eds.). The

Copy Theory of Movement. Amsterdam: John Benjamins, p. 351-385, 2007.

HULSEY, S.;SAUERLAND, U. Sorting out relatives. Natural Language Semantics, v .14, p. 111-137, 2006.

KATO, M.; NUNES, J. Recontando a história das relativas em uma perspectiva paramétrica, In: ROBERTS, I; KATO, M. (Org.). Português Brasileiro Uma Viagem Diacrônica Campinas. Editora da Unicamp, 1993, p. 223-261.

A uniform raising analysis for standard and nonstandard relative clauses in Brazilian Portuguese. In: NUNES, J. (Org.). Minimalist essays on Brazilian Portuguese syntax. Philadelphia: John Benjamins Publishing, p. 93-120, 2009.

Uma análise unificada dos três tipos de relativas restritivas do Português Brasileiro. Web-Revista Sociodialeto, v. 4, n. 12, p. 575-590, 2014.

KAYNE, R. The Antisymmetry of Syntax. Linguistic Inquiry Monograph Twenty-Five. Cambridge: MIT Press, 1994.

KEENAN, E; COMRIE, B. Noun phrase accessibility and universal grammar. Linguistic Inquiry 8, p. 63-99, 1977.

KEFFALA, B.; GOODALL, G. Do resumptive pronouns ever rescue illicit gaps in English? In: 24th Annual CUNY Conference on Human Sentence Processing. Standford, 2011.

KEFFALA, B. Resumption and gaps in English relative clauses: Relative acceptability creates an illusion of 'saving'. In: Proceedings of the 37th Annual Meeting of the Berkeley Linguistics Society, p. 140-154, 2013.

KENEDY, E. Aspectos estruturais da relativização em português - uma análise baseada no modelo raising. Rio de Janeiro, 2002. 158 p. Dissertação de Mestrado. Universidade Federal de Rio de Janeiro. Rio de janeiro.

. A antinaturalidade de pied-piping em orações relativas. Rio de Janeiro, 2007. 237 p. Tese de Doutorado. Faculdade de Letras, Universidade Federal do Rio de Janeiro.

As orações relativas preposicionadas e a hipótese da antinaturalidade de pied-piping. Revista de Estudos Linguísticos Veredas - Psicolinguística, v .1, p. 92-111, 2008.

As relativas preposicionadas padrão são naturais aos falantes do português do brasil? Evidências de pesquisa experimental em psicolinguística. Via Litterae, Anápolis, v .2, n .1, p.58-74,2010. 
KING, J.; JUST, M. Individual differences in syntactic processing: The role of working memory. Journal of Memory and Language, v .30, n. 5, p.580- 602, 1991.

KING, J.; KUTAS, M. Who did what to when?: Using word- and clause-level ERPs to monitor working memory usage in .reading. Journal of Cognitive Neuroscience, v .7, p. 376-395, 1995.

KWON, N.; KLUENDER, R.; KUTAS, M.; POLINSKY, M. Subject/object processing asymmetries in Korean relative clauses: evidence from ERP data. Language (Batim), v .89, n. 3, p.537-585, 2013.

LEVELT, W. J. M. Models of word production. Trends in Cognitive Sciences, v. 3, n. 6, p.223-232, 1989.

LESSA-DE-OLIVEIRA, A. S. C. As sentenças relativas em português brasileiro: aspectos sintáticos e fatores de aquisição. Campinas, 2008. 188 p. Tese de Doutorado. Instituo de Estudos da Linguagem, Universidade Estadual de Campinas.

A relativa resumptiva em dois momentos do português brasileiro. Revista do GEL. São Paulo, v. 6, n. 2, p. 61-84, 2009 a.

Aquisição de relativas e economia. Estudos da Lingua(gem). Vitória da Conquista, v .7, n .2, p.79-108, 2009 b.

LEWIS, S.; PHILLIPS, C. Aligning grammatical theories and language processing models. Journal of Psycholinguistic Research, v. 44, n. 1, p. 27-46, 2015.

LABELLE, M. Predication, wh-movement and the development of relative clauses. Language Acquisition, v. 1, n .1, p. 95-119, 1990.

LONGOBARDI, G. Reference and proper names. Linguistic Inquiry, v .25, p. 609-665, 1994.

MAK, W.; VONK, W.; SCHRIEFERS, H. The influence of animacy on relative clause processing. Journal of Memory and Language, v. 47, n. 1, p. 50-68, 2002.

MCCLOSKEY, J. Resumptive Pronouns, A' Binding, and Levels of representation in Irish. In: Syntax and Semantics of the Modern Celtic Languages. Syntax and Semantics, n .23. Nova York: Academic Press, 1990.

MC DANIEL, D.; COWART, W. Experimental evidence for a minimalista account of English resumptive pronouns. Cognition 70, p. B15-B24, 1999.

MACWHINNEY, B. The processing of restrictive relative clauses in Hungarian. Cognition, v.29, p. 95-141,1988. 
MILLER, G. A; ISARD, S. Free recall of self-embedded English sentences. Information and Control, v. 7, p. 292-303, 1964.

MIOTO, C.; SILVA, M. C.; LOPES, R. Novo Manual de sintaxe. Florianópolis: Insular, 3 ed., 2007.

MIRANDA, F. V. C. O custo de processamento de orações relativas: um estudo experimental sobre relativas com pronome resumptivo no Português Brasileiro. Rio de Janeiro, 2008. 178 p. Dissertação de Mestrado. Departamento de Letras, Pontifícia Universidade Católica do Rio de Janeiro.

MOLLICA, M. C. Anáforas em relativas no Português do Brasil. Alfa, n. 41, p. 171-179, 1997.

Relativas em tempo real no português brasileiro contemporâneo. In: PAIVA, M.C. de e DUARTE, M. E. L. (Orgs.). Mudança linguística em tempo real. Rio de Janeiro: Contracapa/FAPERJ, 2003, p. 129-138.

MORGAN, A.; WAGERS, M. English resumptive pronouns are more common where gaps are less acceptable. Linguistic Inquiry, v. 49, n. 4, p. 861-876, 2018.

PESETSKY, D. Optimality Theory and Syntax: Movement and Pronunciation. In. ARCHANGELI, D. e LANGENDOEN, T. (Eds.). Optimality Theory: An Overview. Blackwell: Mass, 1997, p. 134 -170;

Some optimality principles of sentence pronunciation. In: BARBOSA, P. PESETSKY, D. et al. (Eds.). Is the Best Good Enough: Optimality and Competition in Syntax. Cambridge, Mass.: MIT Press, 1998, p. 337-384.

PHILIPS, C.; WAGERS, M.; LAU, E. Grammatical illusions and selective fallibility in real-time language comprehension. In: RUNNER, J. (Ed.). Experiments at the Interfaces 'Syntax' and 'Semantics. Emerald Publications, v. 37, 2011, p. 147-178.

PICKERING, M. J.; FERREIRA, V. S. Structural Priming: a critical review. Psychological Bulletin, v. 134, n. 3, p. 427-459, 2008.

POLINSKY, M. et al. Resumption in English. In: SPROUSE, J. (Ed.). Experimental syntax and Island effects. Cambridge University Press, 2013, p. 341-360.

RANGEL, M. M. O traço de animacidade e as estratégias de relativização em português brasileiro infantile: um estudo experimental. São Paulo, 2017. Dissertação de Mestrado. Departamento de Linguística, Universidade de São Paulo.

REINHART, T. The Processing Cost of Reference Set Computation: Guess Patterns in Acquisition. OTS Working Papers in Linguistics, 99-001-CL/TL, Utrecht University, Utrecht, The Netherlands, 1999. 
The Processing Cost of Reference Set Computation: Acquisition of Stress

Shift and Focus. Language Acquisition, v. 12, n. 2, p. 109-155, 2004.

RIZZI, L. Relativized Minimality. Cambridge: MIT Press, 1990.

. On some properties of subjects and topics. In: BRUGÉ, L.; GIUSTI, G.; MUNARO, N.; SCHWEIKERT, W.; TURANO, G. (Eds.). Proceedings of the XXX Incontro di Grammatica Generativa, p. 203-224, 2005.

Locality. Lingua, v .130, p.169-186, 2013.

RODRIGUES, C. e DAL POZZO, L. Whose foot is it? Pronominal possessives in pro-drop language: an experimental study. Revista Letras, v. 96, p. 461-486, 2017.

SAFIR, K. Relative clauses in a theory of binding and levels. Lingusitic Inquiry, v. $17, \mathrm{n} .4$, p. 663-689, 1986.

SALZMANN, M. Reconstruction in German relative clauses: in favour of the matching analysis. In: DOTLACIL, J.; GEHRKE, B. (Eds.). UiL OTS Working Papers, p. 65-79, 2006.

- Silent resumptives in Zurich German possessor relativization. In: GallmanN, P.; WRATIL, M. (Eds.). Null Pronouns, p. 141-221. Berlin: Mouton de Gruyter, 2011.

SAUERLAND, U. Two structures for English restrictive relative clauses. In: SAITO, M. et al. Proceedings of the Nanzan Glow, p. 351-366, 2000.

Unpronounced heads in relative clauses. In: SCHWABE, K.; WINKLER, S. (Eds.). The interfaces, p. 205-226. Amsterdam/Philadelphia: John Benjamins, 2003.

SCHÜTZE, C.; SPROUSE, J. Judgment data. In: PODESVA, R.; SHARMA, D. (Eds.). Research Methods in Linguistics, p. 27-50. Cambridge: Cambridge University Press, 2014.

SELLS, P. Syntax and semantics of resumptive pronouns. Cambridge, 1984. Tese de Doutorado. University of Massachusetts.

SHLONSKY, U. Resumptive pronouns as a last resort. Linguistic Inquiry, n. 23, p. 443-468, 1992.

SPROUSE, J. A validation of Amazon Mechanical Turk for the collection of acceptability judgments in linguistic theory. Behav Res, n. 43, p. 155-167, 2011.

STOLZ, W. A study of the ability to decode grammatically novel sentences. Journal of verbal learning and verbal behavior, n .6, p.867-873, 1967.

STOWELL, T. Appositive and parenthetical relative clauses. In: BROEKHUIS, N. CORVER, J.; KOSTER, R.; HUYBREGTS, U. KLEINHENZ (Eds.). Organizing 
Grammar: Linguistic Studies in Honor of Henk van Riemsdijk, Mouton de Gruyter. Berlin/New York, 2005, p. 608-617.

TARALLO, F. Relativization Strategies in Brazilian Portuguese. Pennsylvania, 1983. 295 p. Tese de Doutorado. University of Pennsylvania.

TRAXLER, M.; MORRIS, R.; SEELY, R. Processing Subject and object relative clauses: evidence from eye movements. Journal of Memory and Language, v. 47, p. 69-90, 2002.

VERGNAUD, J.; ZUBIZARRETA, M. The Definite Determiner and Inalienable Construction in French and English. Linguistic Inquiry, v. 23, p. 595-652, 1992.

YNGVE, V. A model and a hypothesis for language structure. Proceedings of the American Philosophical Society, n .104, p. 444-466, 1960.

WANNER, H. E.; MARATSOS, M. P. An ATN approach to comprehension. In: HALLE, M. A.; BRESNAN, J.; MILLER, G.A. (Eds.). Linguistic theory and psychological reality. Cambridge, Mass.: M.I.T. Press, 1978.

WARREN, T.; GIBSON, E. The effects of discourse status on intuitive complexity: Implications for quantifying distance in a locality -based theory of linguistic complexity. Poster presented at the Twelfth CUNY Sentence Processing Conference. New York, 1999.

Cognition, n. 85, p. 79-112, 2002. 


\section{ANEXO I}

Parecer do comitê de ética da PUC-Rio

\section{Pontifícia Universidade C $_{\text {atóllica }}$} DO RIO DE JANEIRO

Câmara de Ética em Pesquisa da PUC - Rio

PARECER DA COMISSÃO DE ÉTICA EM PESQUISA DA PUC-RIO (2017-70)

A Câmara de Ética em Pesquisa da PUC-Rio foi constituída como uma Câmara específica do Conselho de Ensino e Pesquisa conforme decisão deste órgão colegiado com atribuição de avaliar projetos de pesquisa do ponto de vista de suas implicações éticas.

Identificação:

Título: Processamento de orações relativas com resumptivos na produção e compreensão de sentenças (Departamento de Letras da PUC-Rio)

Autora: Danielle Novais Uchôa (Doutoranda do Departamento de Letras da PUC-Rio)

Orientadora: Erica dos Santos Rodrigues (Professora do Departamento de Letras da PUC-Rio)

Coorientadora: Cilene Rodrigues (Professora do Departamento de Letras da PUC-Rio)

Apresentação: O projeto tem como foco a produção e a compreensão de um determinado tipo de estrutura sintática (orações relativas com pronomes resumptivos) por falantes adultos de português brasileiro (falantes de variante padrão). Tem como principais objetivos avaliar o custo relativo da produção dessas estruturas em função de fatores estruturais (como posição sintática do elemento relativizado) e relativos às condições de processamento; verificar a possibilidade de haver pistas prosódicas para a ocorrência do pronome resumptivo, além de avaliar a aceitabilidade de estruturas desse tipo. Está ancorado numa fundamentação dentro da Teoria Gerativa prevendo utilizar junto aos participantes voluntários as técnicas experimentais praticadas no Laboratório de Psicolinguística e Aquisição de Linguagem (LAPAL) da PUC-Rio.

Aspectos éticos: O projeto e os Termos de Consentimento Livre e Esclarecido apresentados estão de acordo com os princípios e valores do Marco Referencial, Estatuto e Regimento da Universidade no que se referem às responsabilidades de seu corpo docente e discente. Os Termos de Consentimento Livre e Esclarecido expõem com clareza os objetivos da pesquisa, os procedimentos a serem seguidos e a garantia do sigilo e da confidencialidade dos dados coletados e da identidade dos participantes. Informam sobre a possibilidade de interrupção na pesquisa sem aplicação de qualquer penalidade ou constrangimento.

Parecer: Considerando os elementos expostos acima somos de parecer Favorável à aprovação do projeto quanto aos princípios e critérios estabelecidos pela Comissão de Ética em Pesquisa da PUC-Rio.

Prof. José Ricdrdo Bergmann

Presidente do Conselho de Ensino e Pesquisa da PUC-Rio 


\title{
ANEXO II
}

Tela de instruções apresentadas aos participantes nos experimentos

\author{
Bem-vindo (a)! \\ Você é convidado a participar de uma pesquisa sobre o português do Brasil. Desde já muito obrigada pela sua participação. \\ Sua participação é voluntária, não havendo nenhum risco associado a essa atividade \\ Suas respostas são estritamente confidenciais e os dados obtidos serão reportados em conjunto. Se você tiver qualquer dúvida sobre a \\ pesquisa ou seus procedimentos, você pode enviar uma mensagem para um dos e-mails que se encontram no fim dessa página. \\ Sua tarefa será ouvir sentenças e julgar se essas são do português do Brasil. \\ Atenção: se você não for falante nativo do português do Brasil, por favor não faça esta atividade, pois ela não medirá sua proficiência na \\ língua. \\ Para escutar as sentenças com maior clareza, é recomendável o uso de fones de ouvido. \\ O teste tem duração aproximada de 15 minutos. \\ É importante que você faça o teste de uma única vez; não é permitido retomar uma atividade não realizada. \\ Muito obrigada pela sua contribuição com a pesquisa! \\ Danielle Novais Uchôa, aluna do Programa de Pós-Graduação em Estudos da Linguagem da PUC-Rio (uchoa.danielle@gmail.com) \\ Orientadoras: \\ Erica dos S. Rodrigues (ericasr@puc-rio.br) e Cilene A. N. Rodrigues (cilene.rodrigues@ucl.ac.uk)
}

Nesta atividade, você ouvirá uma sentença por vez e sua tarefa é analisar se cada sentença ouvida é do português do Brasil, usando uma escala de 0 (zero) a 4 (quatro). Nessa escala, zero significa que a sentença ouvida definitivamente não é possível no português do Brasil e quatro significa que ela é definitivamente possivel no português do Brasil.

Atenção: este não é um teste de gramática tradicional. Não existem respostas certas ou erradas; boas ou ruins. O importante é sua intuição de falante nativo do português do Brasil sobre as sentenças apresentadas. Você deve, portanto, registrar sua primeira impressão no momento de atribuir uma nota.

Clique em Prox. (próximo) para continuar e divirta-se! 


\section{ANEXO III}

Perguntas feitas aos participantes ao final dos experimentos

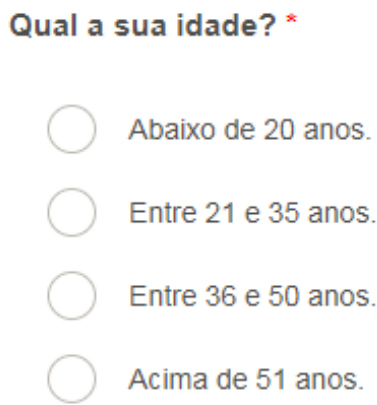

\section{Qual o seu sexo?*}

Acima de 51 anos.

\section{Em qual cidade e estado você nasceu? *}

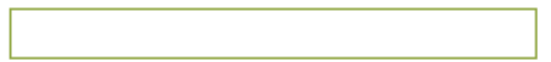

Qual o seu grau de escolaridade?

Incompleto Completo

Ensino Fundamental I $\left(1^{\circ}\right.$ ao

$5^{\circ}$ ano)

Ensino Fundamental II ( $6^{\circ}$ ao

Ensino Médio

Ensino Superior

Pós-Graduação

Caso tenha concluído Ensino Superior, indique abaixo o seu curso. Em caso negativo, escreva Não.

Você domina outro(s) idioma(s) além do Português? Em caso afirmativo, qual (is)? * 


\section{ANEXO IV}

Estímulos usados nos experimentos I e II

\section{Experimento 1}

a) Sentenças experimentais

\section{Resumptivas $\quad$ Padrão}

1. O porteiro que ele salvou uma menina ganhou uma recompensa.

2. A aluna que ela denunciou o professor pediu transferência.

Condição 1: sujeito

Condição 2:

objeto direto

\section{Condição 3:} genitivo
3. A médica indicou o psicólogo que ele estudou na melhor universidade do país.

4. O técnico escalou a jogadora que ela treinou no exterior durante muitos anos.

5. O passageiro que a aeromoça conhecia ele passou mal no avião.

6. A funcionária que o supervisor elogiou ela ganhou um aumento.

7. $\mathrm{O}$ advogado defendeu a garota que o vizinho acusou ela de roubo.

8. A juíza condenou o deputado que a empresária denunciou ele à polícia.

9. O empregado que a esposa dele é muito consumista pediu aumento.

10. A jogadora que o empresário dela desapareceu abandonou a carreira.

11. O médico demitiu a secretária que o primo dela agrediu um paciente.

12. A empresária multou o supervisor que a funcionária dele danificou um equipamento.
1. O porteiro que salvou uma menina ganhou uma recompensa.

2. A aluna que denunciou o professor pediu transferência.

3. A médica indicou o psicólogo que estudou na melhor universidade do país.

4. O técnico escalou a jogadora que ela treinou no exterior durante muitos anos.

5. O passageiro que a aeromoça conhecia passou mal no avião.

6. A funcionária que o supervisor elogiou ganhou um aumento.

7. O advogado defendeu a garota que o vizinho acusou de roubo.

8. A juíza condenou o deputado que a empresária denunciou à polícia.

9. O empregado cuja esposa é muito consumista pediu aumento.

10. A jogadora cujo empresário desapareceu abandonou a carreira.

11. O médico demitiu a secretária cujo primo agrediu um paciente.

12. A empresária multou o supervisor cuja funcionária danificou um equipamento. 
13. O menino que a enfermeira deu pra ele o antibiótico errado foi pro CTI ontem.

14. A nadadora que o prefeito entregou pra ela a tocha Olímpica Condição 4: $\quad$ ganhou uma medalha de ouro. objeto preposicionado

15. A advogada interrogou o menino que a empresária doou pra ele grande quantia de dinheiro.

16. $O$ senador denunciou a deputada que o assessor passou pra ela uma mala cheia de dólares.
13. O menino pra quem a enfermeira deu o antibiótico errado foi pro CTI ontem.

14. A nadadora pra quem o prefeito entregou a tocha Olímpica ganhou uma medalha de ouro.

15. A advogada interrogou o menino pra quem a empresária doou grande quantia de dinheiro.

16. O senador denunciou a deputada pra quem o assessor passou uma mala cheia de dólares.

b) Sentenças distratoras

1. O professor ensinou a mãe como ela deveria nadar o bebê.

2. Isso se eu fosse você não falaria de

3. Ela quando você falar com me avisa

4. Quem a Maria beijou o João depois de ter enviado flores para?

5. Toddy, a criança que toma leite com, passa mal

6. Açúcar, a pessoa que toma café sem, não engorda

7. A Maria, o João dançou com a Fernanda e conversou com

8. Qual time você não gostaria de disputar o campeonato contra?

9. Esse tipo de tecnologia eu não vivo mais sem

10. O deputado cujo fez delação premiada foi absolvido

11. O bebê sempre chora quando a mãe balança na rede.

12. O pirata colocou o tesouro na caixa depois que escondeu na caverna.

13. O avô correu os netos da sala por causa do barulho.

14. A professora estava a corrigir o exercício quando o diretor interrompeu.

15. O chefe afirmou que ausentar-se-á uma semana do escritório.

16. O rapaz resolveu passear o cachorro depois das reclamações da noiva.

17. A mãe decidiu emagrecer o filho pois o médico disse que ele estava com problemas graves de saúde.

18. O que que você não sabe quem vai trazer para a festa?

19. O que que o João disse quando comprou?

20. Ela estava namorando o Pedro quando o João a queria convidar para jantar.

21. O jogador convocou a imprensa para informar que irá se aposentar.

22. A aluna não conseguiu aceitar que foi reprovada por falta.

23. O juiz expulsou o jogador pela falta violenta cometida no primeiro tempo do jogo.

24. O turista disse que o que mais lhe agradou no Brasil foi a simpatia do povo.

\section{Experimento 2}

a) Sentenças experimentais 


\section{Condição 1: Padrão Condição 2: Cortadora genitivo genitivo \\ Condição 3: Resumptiva genitivo}

1. O supervisor cuja estagiária é muito competente pediu aumento.

2. A jogadora cujo empresário desapareceu abandonou a carreira.

3. $O$ juiz puniu a treinadora cujo jogador ofendeu a torcida adversária.

4. A diretora premiou o professor cuja aluna ganhou uma competição.

5. O médico cuja secretária pediu demissão cancelou a agenda desta semana.

6. A reitora conheceu o universitário cuja orientadora foi acusada de assédio.

7. O juiz multou a empresária cujo funcionário trabalhava sem férias por cinco anos.

8. O detento cuja defensora abandonou o caso foi condenado.

9. O garoto cuja babá entrou de férias ficou doente.

10. A médica atendeu o jogador cuja treinadora
1. O supervisor que a estagiária é muito competente pediu aumento.

2. A jogadora que o empresário desapareceu abandonou a carreira.

3. O juiz puniu a treinadora que o jogador ofendeu a torcida adversária.

4. A diretora premiou o professor que a aluna ganhou uma competição.

5. O médico que a secretária

pediu

demissão cancelou a agenda desta semana.

6. A reitora conheceu o universitário que a orientadora foi acusada de assédio.

7. O juiz multou a empresária que o funcionário trabalhava sem férias por cinco anos.

8. O detento que a defensora abandonou o caso foi condenado.

9. O garoto que a babá entrou de férias ficou doente.

10. A médica atendeu o jogador que a treinadora
1. O supervisor que a estagiária dele é muito competente pediu aumento.

2. A jogadora que o empresário dela desapareceu abandonou a carreira.

3. O juiz puniu a treinadora que o jogador dela ofendeu a torcida adversária.

4. A diretora premiou o professor que a aluna dele ganhou uma competição.

5. O médico que a secretária dele pediu demissão cancelou a agenda desta semana.

6. A reitora conheceu o universitário que a orientadora dele foi acusada de assédio.

7. O juiz multou a empresária que o funcionário dela trabalhava sem férias por cinco anos.

8. O detento que a defensora dele abandonou o caso foi condenado.

9. O garoto que a babá dele entrou de férias ficou doente.

10. A médica atendeu o jogador que a treinadora 


\begin{tabular}{lllllll}
\hline $\begin{array}{l}\text { indicou para fazer } \\
\text { tratamento. }\end{array}$ & & $\begin{array}{l}\text { indicou para fazer } \\
\text { tratamento. }\end{array}$ & & $\begin{array}{l}\text { dele indicou para fazer o } \\
\text { tratamento. }\end{array}$
\end{tabular}

11. A aluna cujo orientador criticou foi reprovada no exame.

\section{A empresária} contratou o jogador cuja treinadora é reconhecida mundialmente.

13. A deputada cujo assessor abandonou $\mathrm{O}$ cargo deu entrevista ontem.

14. $O$ diretor elogiou a atriz cujo maquiador faz uma sobrancelha perfeita.

15. O bandido assaltou a milionária cujo empregado deixou a porta aberta.

16. A noiva cujo fotógrafo desmarcou o ensaio cancelou o contrato.

17. O torcedor ofendeu a jogadora cujo técnico invadiu o campo na hora do gol.

18. A garota cujo vizinho é muito barulhento resolveu se mudar.
11. A aluna que o orientador criticou foi reprovada no exame.

12. A empresária contratou o jogador que a treinadora é reconhecida mundialmente.

13. A deputada que o assessor abandonou $\mathrm{O}$ cargo deu entrevista ontem.

14. $\mathrm{O}$ diretor elogiou a atriz que o maquiador faz uma sobrancelha perfeita.

15. O bandido assaltou a milionária que 0 empregado deixou a porta aberta.

16. A noiva que o fotógrafo desmarcou $\mathrm{o}$ ensaio cancelou contrato.

17. O torcedor ofendeu a jogadora que o técnico invadiu o campo na hora do gol.

18. A garota que o vizinho é muito barulhento resolveu se mudar.
11. A aluna que o orientador dela criticou foi reprovada no exame.

12. A empresária contratou o jogador que a treinadora dele é reconhecida mundialmente.

13. A deputada que o assessor dela abandonou o cargo deu entrevista ontem.

14. $O$ diretor elogiou a atriz que o maquiador dela faz uma sobrancelha perfeita.

15. O bandido assaltou a milionária que o empregado dela deixou a porta aberta.

16. A noiva que o fotógrafo dela desmarcou o ensaio cancelou 0 contrato.

17. O torcedor ofendeu a jogadora que o técnico dela invadiu o campo na hora do gol.

18. A garota que o vizinho dela é muito barulhento resolveu se mudar.

\section{Condição 4: Padrão Condição 2: Cortadora oblíquo oblíquo \\ Condição 3: Resumptiva oblíquo}



1. A funcionária com 1. A funcionária que o 1. A funcionária com que quem o diretor simpatiza diretor simpatiza ganhou ganhou uma promoção. uma promoção.
o diretor simpatiza com
ela ganhou uma promoção.

2. O aluno com quem a cozinheira discutiu pediu transferência da escola.

3. O senador demitiu a secretária com quem o deputado topou na manifestação.

4. $\mathrm{O}$ bandido esfaqueou a garota com quem o exnamorado reencontrou antes do assalto.

5. O reitor acusou a professora com quem o inspetor brigou semana passada.

6. $\mathrm{O}$ cantor com quem a blogueira antipatiza pediu desculpas publicamente.

7. A atriz com quem o diretor implicou foi afastada da novela.

8. A psicóloga com quem o motoqueiro desabafou sobre o acidente prestou depoimento.

9. O jurado elogiou a adversária com quem o bailarino competiu no festival.

10. O idoso com quem a cuidadora conviveu sofreu uma queda da escada.
2. O aluno que a cozinheira discutiu pediu transferência da escola.

3. O senador demitiu a secretária que o deputado topou na manifestação.

4. $\mathrm{O}$ bandido esfaqueou a garota que o exnamorado reencontrou antes do assalto.

5. O reitor acusou a professora que o inspetor brigou semana passada.

6. O cantor que a blogueira antipatiza pediu desculpas publicamente.

7. A atriz que o diretor implicou foi afastada da novela.

8. A psicóloga que o motoqueiro desabafou sobre o acidente prestou depoimento.

9. O jurado elogiou a adversária que o bailarino competiu no festival.

10. O idoso que a cuidadora conviveu sofreu uma queda da escada.
2. O aluno que a cozinheira discutiu com ele pediu transferência da escola.

3. O senador demitiu a secretária que o deputado topou com ela na manifestação.

4. $\mathrm{O}$ bandido esfaqueou a garota que o exnamorado dela reencontrou antes do assalto.

5. O reitor acusou a professora que o inspetor brigou com ela semana passada.

6. O cantor que a blogueira antipatiza com ele pediu desculpas publicamente.

7. A atriz com que o diretor implicou com ela foi afastada da novela.

8. A psicóloga que o motoqueiro desabafou com ela sobre o acidente prestou depoimento.

9. O jurado elogiou a adversária que o bailarino competiu com ela no festival.

10. O idoso que a cuidadora conviveu com ele sofreu uma queda da escada. 


\begin{tabular}{|c|c|c|}
\hline $\begin{array}{l}\text { 11. A aposentada } \\
\text { encontrou o garoto com } \\
\text { quem a zeladora sonhou } \\
\text { na noite passada. }\end{array}$ & $\begin{array}{l}\text { 11. A aposentada } \\
\text { encontrou o garoto que a } \\
\text { zeladora sonhou na noite } \\
\text { passada. }\end{array}$ & $\begin{array}{l}\text { 11. A aposentad } \\
\text { encontrou o garoto que } \\
\text { zeladora sonhou com el } \\
\text { na noite passada. }\end{array}$ \\
\hline $\begin{array}{l}\text { 12. A advogada defendeu } \\
\text { o prefeito com quem a } \\
\text { juíza combinou o acordo } \\
\text { de delação premiada. }\end{array}$ & $\begin{array}{l}\text { 12. A advogada defendeu } \\
\text { o prefeito que a juíza } \\
\text { combinou o acordo de } \\
\text { delação premiada. }\end{array}$ & $\begin{array}{l}\text { 12. A advogada defendeu } \\
\text { o prefeito que a juíza } \\
\text { combinou com ele o } \\
\text { acordo de delação } \\
\text { premiada. }\end{array}$ \\
\hline
\end{tabular}

13. A cabeleireira reconheceu o costureiro com quem a noiva concordou sobre o estilo do vestido.

14. A diretora defendeu $o$ aluno com quem a professora colaborou na elaboração do trabalho final.

15. O apresentador com quem a atriz conversou ganhou fama internacional.

16. A delegada com quem o bandido cooperou sofreu um atentado na saída da delegacia.

17. A avaliadora criticou o candidato com quem a pesquisadora concorreu no concurso.

18. O professor com quem a universitária ficou trocou de departamento.
13. A cabeleireira reconheceu o costureiro que a noiva concordou sobre o estilo do vestido.

14. A diretora defendeu o aluno que a professora colaborou na elaboração do trabalho final.

15. O apresentador que a atriz conversou ganhou fama internacional.

16. A delegada que o bandido cooperou sofreu um atentado na saída da delegacia.

17. A avaliadora criticou o candidato que a pesquisadora concorreu no concurso.

18. O professor que a universitária ficou trocou de departamento.
13. A cabeleireira reconheceu o costureiro que a noiva concordou com ele sobre o estilo do vestido.

14. A diretora defendeu o aluno que a professora colaborou com ele na elaboração do trabalho final.

15. O apresentador que a atriz conversou com ele ganhou fama internacional.

16. A delegada que o bandido cooperou com ela sofreu um atentado na saída da delegacia.

17. A avaliadora criticou o candidato que a pesquisadora concorreu com ele no concurso.

18. O professor que a universitária ficou com ele trocou de departamento.

b) Distratoras:

1. O bebê sempre chora quando a mãe balança na rede. 
2. O pirata colocou o tesouro na caixa depois que escondeu na caverna.

3. O segurança presenciou o assalto com a idosa.

4. A chefe pediu para comunicar-te que a empresa passa por uma crise e precisará demitir-te.

5. O juiz mandou a oficial de justiça entregar-lho.

6. A professora estava a corrigir o exercício quando o diretor interrompeu.

7. O avô correu os netos da sala por causa do barulho.

8. O rapaz resolveu passear o cachorro depois das reclamações da noiva.

9. A mãe decidiu emagrecer o filho pois o médico disse que ele estava com problemas graves de saúde.

10. Isso se eu fosse você não falaria de

11. Ela quando você falar com me avisa

12. Toddy, a criança que toma leite com, passa mal

13. O rapaz perguntou sobre o documento cujo ninguém sabia onde estava.

14. O deputado cujo fez delação premiada foi absolvido

15. A supervisora cujo cabelo dela todo mundo gosta foi demitida.

16. A professora perguntou às crianças o que que elas querem ser no futuro.

17. O que que você não sabe quem vai trazer para a festa?

18. O que que o João disse quando comprou?

19. O chefe afirmou que ausentar-se-á uma semana do escritório.

20. Ela estava namorando o Pedro quando o João a queria convidar para jantar.

21. O jogador convocou a imprensa para informar que irá se aposentar.

22. A aluna não conseguiu aceitar que foi reprovada por falta.

23. O jogador foi expulso pela falta violenta cometida no jogo.

24. O turista disse que o que mais lhe agradou no Brasil foi a simpatia do povo.

25. Que os brasileiros são muito alegres é sabido.

26. O motorista assumiu no depoimento que foi o culpado pelo acidente.

27. A cozinheira não assumiu que exagerou no tempero da comida.

28. O presidente anunciou que aumentar-se-ão os impostos.

29. A vítima disse em depoimento que há de se vingar do assaltante.

30. O namorado disse que não admitiria que a namorada tivesse um emprego.

31. A mãe convenceu o filho de que ele deveria seguir a profissão do pai.

32. O padrasto ordenou que a enteada termine a faculdade.

33. A jornalista conseguiu com que o deputado confessasse a compra de votos.

34. Que policial multou a senhora por estacionar em local proibido?

35. O taxista não soube o que fazer quando foi abordado por bandidos.

36. A modelo assumiu em uma entrevista que já sofreu preconceito na adolescência. 


\section{ANEXO V}

Montagem do quadrado latino (experimento 2)

\begin{tabular}{|c|c|c|c|c|c|}
\hline $\begin{array}{l}\text { Frase } 1 \\
\text { Gen } \\
\text { padrão }\end{array}$ & \begin{tabular}{|lr} 
O supervisor & cuja \\
estagiária é & muito \\
competente & pediu \\
aumento. &
\end{tabular} & $\begin{array}{l}\text { Frase } 7 \\
\text { Gen } \\
\text { padrão }\end{array}$ & $\begin{array}{l}\text { O juiz multou a } \\
\text { empresária cujo } \\
\text { funcionário } \\
\text { trabalhava sem férias } \\
\text { por cinco anos. }\end{array}$ & $\begin{array}{l}\text { Frase } 13 \\
\text { Gen } \\
\text { padrão }\end{array}$ & $\begin{array}{l}\text { A deputada cujo } \\
\text { assessor abandonou } \\
\text { o cargo deu } \\
\text { entrevista ontem. }\end{array}$ \\
\hline $\begin{array}{l}\text { Frase } 2 \\
\text { Gen } \\
\text { padrão }\end{array}$ & $\begin{array}{|lr|}\text { A jogadora } & \text { cujo } \\
\text { empresário } & \\
\text { desapareceu } & \\
\text { abandonou } & \text { a } \\
\text { carreira. } & \\
\end{array}$ & $\begin{array}{l}\text { Frase } 8 \\
\text { Gen } \\
\text { padrão }\end{array}$ & 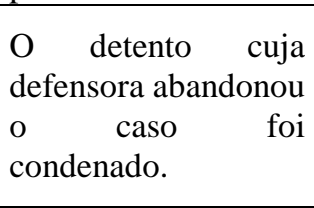 & $\begin{array}{l}\text { Frase } 14 \\
\text { Gen } \\
\text { padrão }\end{array}$ & $\begin{array}{l}\text { O diretor elogiou a } \\
\text { atriz cujo maquiador } \\
\text { fez uma sobrancelha } \\
\text { perfeita. }\end{array}$ \\
\hline $\begin{array}{l}\text { Frase } 3 \\
\text { Gen } \\
\text { padrão }\end{array}$ & \begin{tabular}{|l|} 
O juiz puniu a \\
treinadora cujo \\
jogador ofendeu a \\
torcida adversária. \\
\end{tabular} & $\begin{array}{l}\text { Frase } 9 \\
\text { Gen } \\
\text { padrão }\end{array}$ & $\begin{array}{l}\text { O garoto cuja babá } \\
\text { entrou de férias ficou } \\
\text { doente. }\end{array}$ & $\begin{array}{l}\text { Frase } 15 \\
\text { Gen } \\
\text { padrão }\end{array}$ & $\begin{array}{l}\text { O bandido assaltou a } \\
\text { milionária cujo } \\
\text { mordomo deixou a } \\
\text { porta aberta. }\end{array}$ \\
\hline $\begin{array}{l}\text { Frase } 4 \\
\text { Gen } \\
\text { padrão }\end{array}$ & $\begin{array}{l}\text { A diretora premiou o } \\
\text { professor cuja aluna } \\
\text { ganhou uma } \\
\text { competição. }\end{array}$ & $\begin{array}{l}\text { Frase } 10 \\
\text { Gen } \\
\text { padrão }\end{array}$ & $\begin{array}{l}\text { A médica atendeu o } \\
\text { jogador cuja } \\
\text { treinadora indicou } \\
\text { para fazer o } \\
\text { tratamento }\end{array}$ & $\begin{array}{l}\text { Frase } 16 \\
\text { Gen } \\
\text { padrão }\end{array}$ & $\begin{array}{l}\text { A noiva cujo } \\
\text { fotógrafo desmarcou } \\
\text { o ensaio cancelou o } \\
\text { contrato. }\end{array}$ \\
\hline $\begin{array}{l}\text { Frase } 5 \\
\text { Gen } \\
\text { padrão }\end{array}$ & $\begin{array}{|lr|}\text { O médico } & \text { cuja } \\
\text { secretária } & \text { pediu } \\
\text { demissão cancelou a } \\
\text { agenda } & \text { desta } \\
\text { semana. } & \\
\end{array}$ & $\begin{array}{l}\text { Frase } 11 \\
\text { Gen } \\
\text { padrão }\end{array}$ & $\begin{array}{l}\text { A aluna cujo } \\
\text { orientador criticou } \\
\text { foi reprovada no } \\
\text { exame }\end{array}$ & $\begin{array}{l}\text { Frase } 17 \\
\text { Gen } \\
\text { padrão }\end{array}$ & $\begin{array}{l}\text { O torcedor ofendeu a } \\
\text { jogadora cujo } \\
\text { técnico invadiu o } \\
\text { campo na hora do } \\
\text { gol. }\end{array}$ \\
\hline $\begin{array}{c}\text { Frase } 6 \\
\text { Gen } \\
\text { padrão }\end{array}$ & \begin{tabular}{|lr|}
\multicolumn{4}{|l|}{ A reitora conheceu o } \\
universitário cuja \\
orientadorar foi \\
acusada de assédio.
\end{tabular} & $\begin{array}{l}\text { Frase } 12 \\
\text { Gen } \\
\text { padrão }\end{array}$ & $\begin{array}{l}\text { A empresária } \\
\text { contratou o jogador } \\
\text { cuja treinadora é } \\
\text { reconhecida } \\
\text { mundialmente. }\end{array}$ & $\begin{array}{l}\text { Frase } 18 \\
\text { Gen } \\
\text { padrão }\end{array}$ & $\begin{array}{l}\text { A garota cujo } \\
\text { vizinho é muito } \\
\text { barulhento resolveu } \\
\text { se mudar. }\end{array}$ \\
\hline $\begin{array}{l}\text { Frase } 7 \\
\text { Gen } \\
\text { cortadora }\end{array}$ & $\begin{array}{l}\text { O juiz multou a } \\
\text { empresária que } \quad \text { o } \\
\text { funcionário } \\
\text { trabalhava } \\
\text { férias por sem } \\
\text { anos. }\end{array}$ & $\begin{array}{l}\text { Frase } 13 \\
\text { Gen } \\
\text { cortadora }\end{array}$ & $\begin{array}{l}\text { A deputada que o } \\
\text { assessor abandonou } \\
\text { o cargo deu } \\
\text { entrevista ontem. }\end{array}$ & $\begin{array}{c}\text { Frase } 1 \text { Gen } \\
\text { cortadora }\end{array}$ & $\begin{array}{l}\text { O supervisor que a } \\
\text { estagiária é } \\
\text { competente } \\
\text { aumento. }\end{array}$ \\
\hline $\begin{array}{l}\text { Frase } 8 \\
\text { Gen } \\
\text { cortadora }\end{array}$ & $\begin{array}{l}\text { O detento que a } \\
\text { defensora } \\
\text { abandonou o caso } \\
\text { foi condenado. }\end{array}$ & $\begin{array}{l}\text { Frase } 14 \\
\text { Gen } \\
\text { cortadora }\end{array}$ & $\begin{array}{l}\text { O diretor elogiou a } \\
\text { atriz que o } \\
\text { maquiador fez uma } \\
\text { sombrancelha } \\
\text { perfeita. }\end{array}$ & $\begin{array}{c}\text { Frase } 2 \\
\text { Gen } \\
\text { cortadora }\end{array}$ & 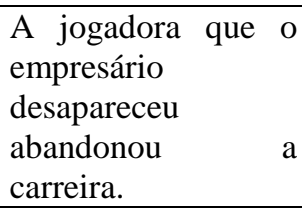 \\
\hline $\begin{array}{l}\text { Frase } 9 \\
\text { Gen } \\
\text { cortadora }\end{array}$ & $\begin{array}{l}\text { O garoto que a babá } \\
\text { entrou de férias } \\
\text { ficou doente. }\end{array}$ & $\begin{array}{l}\text { Frase } 15 \\
\text { Gen } \\
\text { cortadora }\end{array}$ & $\begin{array}{l}\text { O bandido assaltou a } \\
\text { milionária que o } \\
\text { mordomo deixou a } \\
\text { porta aberta. }\end{array}$ & $\begin{array}{c}\text { Frase } 3 \\
\text { Gen } \\
\text { cortadora }\end{array}$ & $\begin{array}{l}\text { O juiz puniu a } \\
\text { treinadora que o } \\
\text { jogador ofendeu a } \\
\text { torcida adversária. }\end{array}$ \\
\hline $\begin{array}{l}\text { Frase } 10 \\
\text { Gen } \\
\text { cortadora }\end{array}$ & $\begin{array}{l}\text { A médica atendeu o } \\
\text { jogador que a } \\
\text { treinadora indicou } \\
\text { para fazer o } \\
\text { tratamento. }\end{array}$ & $\begin{array}{l}\text { Frase } 16 \\
\text { Gen } \\
\text { cortadora }\end{array}$ & $\begin{array}{l}\text { A noiva que o } \\
\text { fotógrafo desmarcou } \\
\text { o ensaio cancelou o } \\
\text { contrato. }\end{array}$ & $\begin{array}{c}\text { Frase } 4 \\
\text { Gen } \\
\text { cortadora }\end{array}$ & $\begin{array}{l}\text { A diretora premiou o } \\
\text { professor que a } \\
\text { aluna ganhou uma } \\
\text { competição. }\end{array}$ \\
\hline $\begin{array}{l}\text { Frase } 11 \\
\text { Gen } \\
\text { cortadora }\end{array}$ & $\begin{array}{l}\text { A aluna que o } \\
\text { orientador criticou } \\
\text { foi reprovada no } \\
\text { exame }\end{array}$ & $\begin{array}{l}\text { Frase } 17 \\
\text { Gen } \\
\text { cortadora }\end{array}$ & $\begin{array}{l}\text { O torcedor ofendeu a } \\
\text { jogadora que o } \\
\text { técnico invadiu o } \\
\text { campo na hora do gol }\end{array}$ & $\begin{array}{c}\text { Frase } 5 \\
\text { Gen } \\
\text { cortadora }\end{array}$ & $\begin{array}{lr}\text { O médico que a } \\
\text { secretária } & \text { pediu } \\
\text { demissão cancelou a } \\
\text { agenda } & \text { desta } \\
\text { semana. } & \\
\end{array}$ \\
\hline
\end{tabular}




\begin{tabular}{|c|c|c|c|c|c|}
\hline $\begin{array}{l}\text { Frase } 12 \\
\text { Gen } \\
\text { cortadora }\end{array}$ & \begin{tabular}{|l|} 
A \\
contratou o jogador \\
que a treinadora é \\
reconhecida \\
mundialmente. \\
\end{tabular} & $\begin{array}{l}\text { Frase } 18 \\
\text { Gen } \\
\text { cortadora }\end{array}$ & $\begin{array}{l}\text { A garota que o } \\
\text { vizinho é muito } \\
\text { barulhento resolveu } \\
\text { se mudar. }\end{array}$ & $\begin{array}{c}\text { Frase } 6 \\
\text { Gen } \\
\text { cortadora }\end{array}$ & $\begin{array}{l}\text { A reitora conheceu o } \\
\text { universitário que a } \\
\text { orientadora foi } \\
\text { acusada de assédio. }\end{array}$ \\
\hline $\begin{array}{c}\text { Frase } 13 \\
\text { Gen } \\
\text { resumptiva }\end{array}$ & $\begin{array}{lrr}\text { A deputada } & \text { que o } \\
\text { assessor } & & \text { dela } \\
\text { abandonou } & \text { o } & \text { cargo } \\
\text { deu } & \text { entrevista } \\
\text { ontem. } & \end{array}$ & $\begin{array}{c}\text { Frase 1 } \\
\text { Gen } \\
\text { resumptiva }\end{array}$ & $\begin{array}{l}\text { O supervisor que a } \\
\text { estagiária dele é } \\
\text { muito competente } \\
\text { pediu aumento. }\end{array}$ & $\begin{array}{c}\text { Frase } 7 \\
\text { Gen } \\
\text { resumptiva }\end{array}$ & $\begin{array}{lr}\text { O juiz multou a } \\
\text { empresária que o } \\
\text { funcionário } & \text { dela } \\
\text { trabalhava } & \text { sem } \\
\text { férias por } & \text { cinco } \\
\text { anos. }\end{array}$ \\
\hline $\begin{array}{l}\text { Frase } 14 \\
\text { Gen } \\
\text { resumptiva }\end{array}$ & \begin{tabular}{|l} 
O diretor elogiou a \\
atriz que \\
maquiador dela fez \\
uma sombrancelha \\
perfeita.
\end{tabular} & $\begin{array}{c}\text { Frase } 2 \\
\text { Gen } \\
\text { resumptiva }\end{array}$ & $\begin{array}{l}\text { A jogadora que o } \\
\text { empresário dela } \\
\text { desapareceu } \\
\text { abandonou a carreira. }\end{array}$ & $\begin{array}{c}\text { Frase } 8 \\
\text { Gen } \\
\text { resumptiva }\end{array}$ & 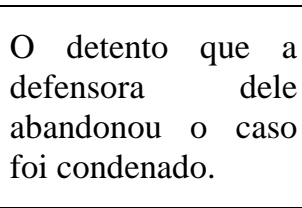 \\
\hline $\begin{array}{l}\text { Frase } 15 \\
\text { Gen } \\
\text { resumptiva }\end{array}$ & $\begin{array}{lrr}\text { O bandido assaltou a } \\
\text { milionária } & \text { que o } \\
\text { mordomo } & \text { dela } \\
\text { deixou } & \text { a } & \text { porta } \\
\text { aberta. } & & \\
\end{array}$ & $\begin{array}{c}\text { Frase } 3 \\
\text { Gen } \\
\text { resumptiva }\end{array}$ & $\begin{array}{l}\text { O juiz puniu a } \\
\text { treinadora que o } \\
\text { jogador dela ofendeu } \\
\text { a torcida adversária. }\end{array}$ & $\begin{array}{c}\text { Frase } 9 \\
\text { Gen } \\
\text { resumptiva }\end{array}$ & $\begin{array}{l}\text { O garoto que a babá } \\
\text { dele entrou de férias } \\
\text { ficou doente. }\end{array}$ \\
\hline $\begin{array}{l}\text { Frase } 16 \\
\text { Gen } \\
\text { resumptiva }\end{array}$ & $\begin{array}{l}\text { A noiva que o } \\
\text { fotógrafo } \\
\text { desmarcou } \\
\text { cancelou o ensaio } \\
\text { cantrato. }\end{array}$ & $\begin{array}{c}\text { Frase } 4 \\
\text { Gen } \\
\text { resumptiva }\end{array}$ & $\begin{array}{l}\text { A diretora premiou o } \\
\text { professor que a aluna } \\
\text { dele ganhou uma } \\
\text { competição. }\end{array}$ & $\begin{array}{c}\text { Frase } 10 \\
\text { Gen } \\
\text { resumptiva }\end{array}$ & $\begin{array}{l}\text { A médica atendeu o } \\
\text { jogador que a } \\
\text { treinadora dele } \\
\text { indicou para fazer o } \\
\text { tratamento }\end{array}$ \\
\hline $\begin{array}{c}\text { Frase } 17 \\
\text { Gen } \\
\text { resumptiva }\end{array}$ & $\begin{array}{l}\text { O torcedor ofendeu a } \\
\text { jogadora que o } \\
\text { técnico dela invadiu } \\
\text { o campo na hora do } \\
\text { gol. }\end{array}$ & $\begin{array}{c}\text { Frase } 5 \\
\text { Gen } \\
\text { resumptiva }\end{array}$ & $\begin{array}{l}\text { O médico que a } \\
\text { secretária dele pediu } \\
\text { demissão cancelou a } \\
\text { agenda desta semana. }\end{array}$ & $\begin{array}{c}\text { Frase } 11 \\
\text { Gen } \\
\text { resumptiva }\end{array}$ & $\begin{array}{lr}\text { A aluna que o } \\
\text { orientador } & \text { dela } \\
\text { criticou } & \text { foi } \\
\text { reprovada no exame }\end{array}$ \\
\hline $\begin{array}{c}\text { Frase } 18 \\
\text { Gen } \\
\text { resumptiva }\end{array}$ & $\begin{array}{l}\text { A garota que o } \\
\text { vizinho dela é muito } \\
\text { barulhento resolveu } \\
\text { se mudar. }\end{array}$ & $\begin{array}{c}\text { Frase } 6 \\
\text { Gen } \\
\text { resumptiva }\end{array}$ & $\begin{array}{l}\text { A reitora conheceu o } \\
\text { universitário que a } \\
\text { orientadora dele foi } \\
\text { acusada de assédio. }\end{array}$ & $\begin{array}{c}\text { Frase } 12 \\
\text { Gen } \\
\text { resumptiva }\end{array}$ & $\begin{array}{l}\text { A empresária } \\
\text { contratou o jogador } \\
\text { que a treinadora dele } \\
\text { érar reconhecida } \\
\text { mundialmente. } \\
\end{array}$ \\
\hline $\begin{array}{l}\text { Frase } 1 \\
\text { Obl } \\
\text { padrão }\end{array}$ & $\begin{array}{l}\text { A funcionária com } \\
\text { quem o diretor } \\
\text { simpatiza ganhou } \\
\text { uma promoção. }\end{array}$ & $\begin{array}{c}\text { Frase } 7 \\
\text { Obl } \\
\text { padrão }\end{array}$ & $\begin{array}{l}\text { A atriz com quem o } \\
\text { diretor implicou foi } \\
\text { afastada da novela. }\end{array}$ & $\begin{array}{l}\text { Frase } 13 \\
\text { Obl } \\
\text { padrão }\end{array}$ & $\begin{array}{lr}\text { A cabeleireira } \\
\text { reconheceu } \\
\text { costureiro } \\
\text { quem a com } \\
\text { concordou sobre o } \\
\text { estilo do vestido. } \\
\end{array}$ \\
\hline $\begin{array}{c}\text { Frase } 2 \\
\text { Obl } \\
\text { padrão }\end{array}$ & $\begin{array}{l}\text { O aluno com quem a } \\
\text { cozinheira discutiu } \\
\text { pediu transferência } \\
\text { da escola. }\end{array}$ & $\begin{array}{c}\text { Frase } 8 \\
\text { Obl } \\
\text { padrão }\end{array}$ & $\begin{array}{l}\text { A psicóloga com } \\
\text { quem o motoqueiro } \\
\text { desabafou sobre o } \\
\text { acidente prestou } \\
\text { depoimento. }\end{array}$ & $\begin{array}{l}\text { Frase } 14 \\
\text { Obl } \\
\text { padrão }\end{array}$ & $\begin{array}{l}\text { A diretora defendeu } \\
\text { o aluno com quem a } \\
\text { professora } \\
\text { colaborou } \\
\text { elaboração na } \\
\text { trabalho final do }\end{array}$ \\
\hline $\begin{array}{c}\text { Frase } 3 \\
\text { Obl } \\
\text { padrão }\end{array}$ & $\begin{array}{l}\text { O senador demitiu a } \\
\text { secretária com quem } \\
\text { o deputado topou na } \\
\text { manifestação }\end{array}$ & $\begin{array}{c}\text { Frase } 9 \\
\text { Obl } \\
\text { padrão }\end{array}$ & $\begin{array}{l}\text { O jurado elogiou a } \\
\text { adversária com quem } \\
\text { o bailarino competiu } \\
\text { no festival. }\end{array}$ & $\begin{array}{l}\text { Frase } 15 \\
\text { Obl } \\
\text { padrão }\end{array}$ & $\begin{array}{l}\text { O apresentador com } \\
\text { quem a atriz } \\
\text { conversou ganhou } \\
\text { fama internacional. }\end{array}$ \\
\hline $\begin{array}{c}\text { Frase } 4 \\
\text { Obl } \\
\text { padrão }\end{array}$ & $\begin{array}{lr}\mathrm{O} & \text { bandido } \\
\text { esfaqueou a } & \text { garota } \\
\text { com quem } & \mathrm{o} \text { ex- } \\
\text { namorado } & \\
\text { reencontrou antes do } \\
\text { assalto. }\end{array}$ & $\begin{array}{l}\text { Frase } 10 \\
\text { Obl } \\
\text { padrão }\end{array}$ & $\begin{array}{l}\text { O idoso com quem a } \\
\text { cuidadora conviveu } \\
\text { sofreu uma queda da } \\
\text { escada. }\end{array}$ & $\begin{array}{c}\text { Frase } 16 \\
\text { Obl } \\
\text { padrão }\end{array}$ & $\begin{array}{l}\text { A delegada com } \\
\text { quem o bandido } \\
\text { cooperou sofreu um } \\
\text { atentado na saída da } \\
\text { delegacia. }\end{array}$ \\
\hline
\end{tabular}




\begin{tabular}{|c|c|c|c|c|c|}
\hline $\begin{array}{c}\text { Frase } 5 \\
\text { Obl } \\
\text { padrão }\end{array}$ & $\mid \begin{array}{lr}\text { O reitor } & \text { acusou a } \\
\text { professora } & \text { com } \\
\text { quem o } & \text { inspetor } \\
\text { brigou } & \text { semana } \\
\text { passada. } & \end{array}$ & $\begin{array}{l}\text { Frase } 11 \\
\text { Obl } \\
\text { padrão }\end{array}$ & $\begin{array}{l}\text { A aposentada } \\
\text { encontrou o garoto } \\
\text { com quem a zeladora } \\
\text { sonhou na noite } \\
\text { passada. }\end{array}$ & $\begin{array}{l}\text { Frase } 17 \\
\text { Obl } \\
\text { padrão }\end{array}$ & \begin{tabular}{|lr} 
A & avaliadora \\
criticou o candidato \\
com quem a \\
pesquisadora \\
concorreu \\
concurso.
\end{tabular} \\
\hline $\begin{array}{c}\text { Frase } 6 \\
\text { Obl } \\
\text { padrão }\end{array}$ & 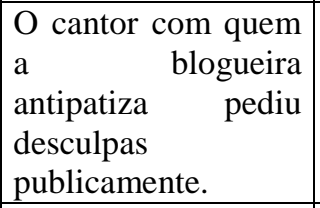 & $\begin{array}{l}\text { Frase } 12 \\
\text { Obl } \\
\text { padrão }\end{array}$ & 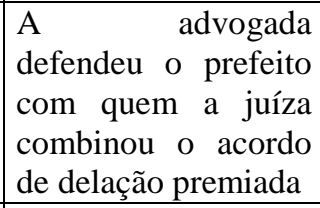 & $\begin{array}{l}\text { Frase } 18 \\
\text { Obl } \\
\text { padrão }\end{array}$ & $\begin{array}{l}\text { O professor com } \\
\text { quem a universitária } \\
\text { ficou trocou de } \\
\text { departamento. }\end{array}$ \\
\hline $\begin{array}{c}\text { Frase } 7 \\
\text { Obl } \\
\text { cortadora }\end{array}$ & $\begin{array}{l}\text { A atriz que o diretor } \\
\text { implicou foi } \\
\text { afastada da novela. }\end{array}$ & $\begin{array}{l}\text { Frase } 13 \\
\text { Obl } \\
\text { cortadora }\end{array}$ & $\begin{array}{|lr|}\text { A } & \text { cabeleireira } \\
\text { reconheceu } & \text { o } \\
\text { costureiro que a } \\
\text { noiva concordou } \\
\text { sobre o estilo do } \\
\text { vestido. } \\
\end{array}$ & $\begin{array}{l}\text { Frase } 1 \\
\text { Obl } \\
\text { cortadora }\end{array}$ & $\begin{array}{lr}\text { A funcionária que o } \\
\text { diretor } & \text { simpatiza } \\
\text { ganhou } & \text { uma } \\
\text { promoção. } & \end{array}$ \\
\hline $\begin{array}{c}\text { Frase } 8 \\
\text { Obl } \\
\text { cortadora }\end{array}$ & $\begin{array}{|ll|}\text { A psicóloga } & \text { que } \\
\text { motoqueiro } & \\
\text { desabafou } & \text { sobre } \quad \text { o } \\
\text { acidente } & \text { prestou } \\
\text { depoimento. } & \\
\end{array}$ & $\begin{array}{l}\text { Frase } 14 \\
\text { Obl } \\
\text { cortadora }\end{array}$ & $\begin{array}{l}\text { A diretora defendeu } \\
\text { o aluno que a } \\
\text { professora colaborou } \\
\text { na elaboração do } \\
\text { trabalho final. } \\
\end{array}$ & $\begin{array}{l}\text { Frase } 2 \\
\text { Obl } \\
\text { cortadora }\end{array}$ & $\begin{array}{l}\text { O aluno que a } \\
\text { cozinheira discutiu } \\
\text { pediu transferência } \\
\text { da escola. }\end{array}$ \\
\hline $\begin{array}{c}\text { Frase } 9 \\
\text { Obl } \\
\text { cortadora }\end{array}$ & \begin{tabular}{|l|} 
O jurado elogiou a \\
adversária que o \\
bailarino competiu \\
no festival. \\
\end{tabular} & $\begin{array}{l}\text { Frase } 15 \\
\text { Obl } \\
\text { cortadora }\end{array}$ & \begin{tabular}{|lr} 
O apresentador que a \\
atriz conversou \\
ganhourama \\
internacional.
\end{tabular} & $\begin{array}{l}\text { Frase } 3 \\
\text { Obl } \\
\text { cortadora }\end{array}$ & $\begin{array}{l}\text { O senador demitiu a } \\
\text { secretária que o } \\
\text { deputado topou na } \\
\text { manifestação }\end{array}$ \\
\hline $\begin{array}{l}\text { Frase } 10 \\
\text { Obl } \\
\text { cortadora }\end{array}$ & $\begin{array}{l}\text { O idoso que a } \\
\text { cuidadora conviveu } \\
\text { sofreu uma } \\
\text { escada. }\end{array}$ & $\begin{array}{l}\text { Frase } 16 \\
\text { Obl } \\
\text { cortadora }\end{array}$ & $\begin{array}{l}\text { A delegada que o } \\
\text { bandido cooperou } \\
\text { sofreu um atentado } \\
\text { na saída da } \\
\text { delegacia. }\end{array}$ & $\begin{array}{c}\text { Frase } 4 \\
\text { Obl } \\
\text { cortadora }\end{array}$ & $\begin{array}{lr}\text { O } & \text { bandido } \\
\text { esfaqueou a garota } \\
\text { que o ex-namorado } \\
\text { reencontrou antes } \\
\text { do assalto. } \\
\end{array}$ \\
\hline $\begin{array}{l}\text { Frase } 11 \\
\text { Obl } \\
\text { cortadora }\end{array}$ & $\begin{array}{|lrr|}\text { A } & \text { aposentada } \\
\text { encontrou } & \text { o } & \text { garoto } \\
\text { que a } & \text { zeladora } \\
\text { sonhou na } & \text { noite } \\
\text { passada. } & & \\
\end{array}$ & $\begin{array}{l}\text { Frase } 17 \\
\text { Obl } \\
\text { cortadora }\end{array}$ & $\begin{array}{l}\text { A avaliadora criticou } \\
\text { o candidato que a } \\
\text { pesquisadora } \\
\text { concorreu no } \\
\text { concurso. }\end{array}$ & $\begin{array}{l}\text { Frase } 5 \\
\text { Obl } \\
\text { cortadora }\end{array}$ & $\begin{array}{l}\text { O reitor acusou a } \\
\text { professora que o } \\
\text { inspetor brigou } \\
\text { semana passada. }\end{array}$ \\
\hline $\begin{array}{l}\text { Frase } 12 \\
\text { Obl } \\
\text { cortadora }\end{array}$ & $\begin{array}{|lrr|}\text { A } & & \text { advogada } \\
\text { defendeu } & \text { o } & \text { prefeito } \\
\text { que } & \text { a } & \text { juíza } \\
\text { combinou } & \text { o } & \text { acordo } \\
\text { de delação } & \text { premiada } \\
\end{array}$ & $\begin{array}{l}\text { Frase } 18 \\
\text { Obl } \\
\text { cortadora }\end{array}$ & \begin{tabular}{|lr} 
O professor que a \\
universitária ficou \\
trocou & de \\
departamento. &
\end{tabular} & $\begin{array}{l}\text { Frase } 6 \\
\text { Obl } \\
\text { cortadora }\end{array}$ & $\begin{array}{l}\text { O cantor que a } \\
\text { bloqueira antipatiza } \\
\text { pediu desculpas } \\
\text { publicamente. }\end{array}$ \\
\hline $\begin{array}{l}\text { Frase } 13 \\
\text { Obl } \\
\text { resumptiva }\end{array}$ & 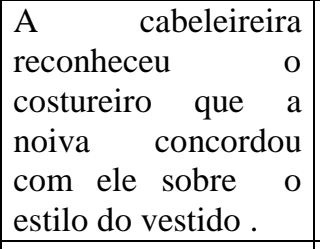 & $\begin{array}{c}\text { Frase 1 } \\
\text { Obl } \\
\text { resumptiva }\end{array}$ & $\begin{array}{l}\text { A funcionária que o } \\
\text { diretor simpatiza } \\
\text { com ela ganhou uma } \\
\text { promoção. }\end{array}$ & $\begin{array}{c}\text { Frase } 7 \\
\text { Obl } \\
\text { resumptiva }\end{array}$ & $\begin{array}{l}\text { A atriz que o diretor } \\
\text { implicou com ela foi } \\
\text { afastada da novela. }\end{array}$ \\
\hline $\begin{array}{l}\text { Frase } 14 \\
\text { Obl } \\
\text { resumptiva }\end{array}$ & \begin{tabular}{|lr} 
A diretora defendeu \\
o aluno que a \\
professora \\
colaborou com ele \\
na elaboração do \\
trabalho final. \\
\end{tabular} & $\begin{array}{c}\text { Frase } 2 \\
\text { Obl } \\
\text { resumptiva }\end{array}$ & $\begin{array}{lr}\text { O aluno que a } \\
\text { cozinheira discutiu } \\
\text { com ele } & \text { pediu } \\
\text { transferência } & \text { da } \\
\text { escola. } & \end{array}$ & $\begin{array}{c}\text { Frase } 8 \\
\text { Obl } \\
\text { resumptiva }\end{array}$ & $\begin{array}{l}\text { A psicóloga que o } \\
\text { motoqueiro } \\
\text { desabafou com ela } \\
\text { sobre o acidente } \\
\text { prestou depoimento. }\end{array}$ \\
\hline $\begin{array}{l}\text { Frase } 15 \\
\text { Obl } \\
\text { resumptiva }\end{array}$ & $\begin{array}{l}\text { O apresentador que a } \\
\text { atriz conversou com } \\
\text { ele ganhou fama } \\
\text { internacional. }\end{array}$ & $\begin{array}{c}\text { Frase } 3 \\
\text { Obl } \\
\text { resumptiva }\end{array}$ & $\begin{array}{l}\text { O senador demitiu a } \\
\text { secretária que o } \\
\text { deputado topou com } \\
\text { ela na manifestação }\end{array}$ & $\begin{array}{c}\text { Frase } 9 \\
\text { Obl } \\
\text { resumptiva }\end{array}$ & $\begin{array}{l}\text { O jurado elogiou a } \\
\text { adversária que o } \\
\text { bailarino competiu } \\
\text { com ela no festival. }\end{array}$ \\
\hline
\end{tabular}




\begin{tabular}{|c|c|c|c|c|c|}
\hline $\begin{array}{c}\text { Frase } 16 \\
\text { Obl } \\
\text { resumptiva }\end{array}$ & $\begin{array}{l}\text { A delegada que o } \\
\text { bandido cooperou } \\
\text { com ela sofreu um } \\
\text { atentado na saída da } \\
\text { delegacia. }\end{array}$ & $\begin{array}{c}\text { Frase } 4 \\
\text { Obl } \\
\text { resumptiva }\end{array}$ & $\begin{array}{l}\text { O bandido esfaqueou } \\
\text { a garota que o ex- } \\
\text { namorado } \\
\text { reencontrou com ela } \\
\text { antes do assalto. }\end{array}$ & $\begin{array}{c}\text { Frase } 10 \\
\text { Obl } \\
\text { resumptiva }\end{array}$ & $\begin{array}{l}\text { O idoso que a } \\
\text { cuidadora conviveu } \\
\text { com ele sofreu uma } \\
\text { queda da escada. }\end{array}$ \\
\hline $\begin{array}{l}\text { Frase } 17 \\
\text { Obl } \\
\text { resumptiva }\end{array}$ & $\begin{array}{l}\text { A criticou o candidato } \\
\text { criadora } \\
\text { que a pesquisadora } \\
\text { concorreu com ele } \\
\text { no concurso. }\end{array}$ & $\begin{array}{c}\text { Frase } 5 \\
\text { Obl } \\
\text { resumptiva }\end{array}$ & $\begin{array}{l}\text { O reitor acusou a } \\
\text { professora que o } \\
\text { inspetor brigou com } \\
\text { ela semana passada. }\end{array}$ & $\begin{array}{c}\text { Frase } 11 \\
\text { Obl } \\
\text { resumptiva }\end{array}$ & $\begin{array}{l}\text { A aposentada } \\
\text { encontrou o garoto } \\
\text { que a zeladora } \\
\text { sonhou com ele na } \\
\text { noite passada. }\end{array}$ \\
\hline $\begin{array}{c}\text { Frase } 18 \\
\text { Obl } \\
\text { resumptiva }\end{array}$ & $\begin{array}{l}\text { O professor que a } \\
\text { universitária ficou } \\
\text { com ele trocou de } \\
\text { departamento. }\end{array}$ & $\begin{array}{c}\text { Frase 6 } \\
\text { Obl } \\
\text { resumptiva }\end{array}$ & $\begin{array}{l}\text { O cantor que a } \\
\text { bloqueira antipatiza } \\
\text { com ele pediu } \\
\text { desculpas } \\
\text { publicamente. }\end{array}$ & $\begin{array}{c}\text { Frase } 12 \\
\text { Obl } \\
\text { resumptiva }\end{array}$ & $\begin{array}{lrr}\text { A } & \text { advogada } \\
\text { defendeu o prefeito } \\
\text { que a juíza } \\
\text { combinou com ele o } \\
\text { acordo de delação } \\
\text { premiada }\end{array}$ \\
\hline
\end{tabular}




\section{ANEXO VI}

Termo de consentimento livre e esclarecido utilizado nos experimentos 3 e 4

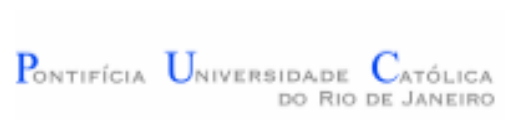

Termo de Consentimento Livre e Esclarecido (TCLE)

Experimento de compreensão de sentenças

\section{PONTIFÍCIA UNIVERSIDADE CATÓLICA DO RIO DE JANEIRO PROGRAMA DE PÓS-GRADUAÇÃO EM ESTUDOS DA \\ LINGUAGEM - PPGEL \\ LAPAL - LABORATÓRIO DE PSICOLINGUÍSTICA E AQUISIÇÃO \\ DA LINGUAGEM}

Este termo de consentimento livre e esclarecido pode conter trechos que não estejam claros para seu entendimento. Peça ao pesquisador(a) que explique as informações que você desejar.

\section{Do convite}

Você foi convidado(a) a participar desta pesquisa por atender a pré-requisitos necessários. Se decidir participar, é importante que você leia as informações contidas neste documento a respeito do estudo e do seu papel nesta atividade. Sua participação não é obrigatória, e, a qualquer momento, você pode desistir de participar e retirar seu consentimento. Sua recusa não trará nenhum prejuizo à relação com o pesquisador ou com a Pontifícia Universidade Católica do Rio de Janeiro. É preciso entender a natureza de sua participação e dar o seu consentimento livre e esclarecido por escrito ao final deste documento. Você poderá fazer todas as perguntas que precisar para entender os objetivos da pesquisa, esclarecer dúvidas e inteirar-se dos possíveis beneficios desta empreitada. Você receberá uma cópia desde termo no qual constam as informações relativas à pesquisa bem como os contatos (telefone, e-mail e endereço) dos pesquisadores, por meio dos quais você poderá dirimir dúvidas acerca do projeto e de sua participação. Caso seja de seu interesse, deixe seu nome completo e e-mail ao final deste termo para que possamos enviar a você uma cópia de uma possível publicação referente a esta pesquisa.

Em caso de concordar em participar desta pesquisa, o participante deverá assinar este termo em duas vias, uma que ficará em sua posse e a outra pertencente à pesquisadora.

\section{Dos pesquisadores}

Esta pesquisa tem como responsáveis a Profa. Dra. Erica dos Santos Rodrigues, professora do PPGEL, cujo endereço é Rua Marquês de S. Vicente, 225 Ala Kennedy, sala K-121 Gávea - Rio de Janeiro, CEP: 22451-900; +55 (21) 3527-1297, ericasr@apucrio.br e a doutoranda Danielle Novais Uchôa, orientanda da professora supracitada; +55 (32) 9195-1072, uchoa.danielle $a$ gmail.com. 


\section{Do objetivo e da justificativa}

O objetivo deste estudo é entender melhor como individuos adultos, falantes nativos do português brasileiro, compreendem sentenças com determinadas estruturas, com vistas a caracterizar como se dá o processamento sintático em situações de compreensão de sentenças.

\section{Do procedimento}

Se concordar em participar deste estudo, você será solicitado a ler algumas sentenças, que serão apresentadas na tela de um computador. Sua tarefa será avaliar cada sentença, atribuindo-lhe nota e/ou respondendo a perguntas de compreensão. O material coletado durante esta tarefa será catalogado sob um número de referência, preservando-se a confidencialidade de seus dados pessoais, e será analisado de acordo com fundamentos teóricos e métodos de análise que orientam esta pesquisa. A duração estimada desta atividade é de $20 \mathrm{~min}$.

\section{Dos desconfortos e riscos}

A coleta de dados ocorrerá por meio de um laptop em um ambiente que seja confortável para o participante e cuja influência de elementos extemos, tais como ruidos, conversas, barulhos provenientes do trânsito, etc., seja mínima. Os possiveis riscos associados a essa atividade são mínimos, os mesmos relacionados a atividades que envolvam leitura de textos em tela de computador, ou a assistir a programas de TV, por exemplo. Salienta-se, no entanto, que esta pesquisa será realizada somente se você se sentir em boas condições físicas e emocionais para realizar as tarefas e a atividade poderá ser interrompida a qualquer momento que você solicitar.

\section{Dos beneficios esperados}

Esta tarefa não the trará beneficios diretos. Todavia as informações obtidas serão de extrema relevância para o entendimento de aspectos morfossintáticos envolvidos no processamento de sentenças em Português Brasileiro em situação de compreensão de linguagem.

\section{Dos custos e reembolsos para o participante}

Sua participação deve ser espontânea e voluntária. Você não terá nenhum tịpo de despesa para participar desta pesquisa, bem como nada será pago por sua participação.

\section{Da confidencialidade}

Todas as informações coletadas neste estudo são estritamente confidenciais. Somente a pesquisadora e a orientadora terão conhecimento de seus dados pessoais. Você munca será identificado quando o material de seu registro for utilizado, seja para propósitos de publicação cientifica ou educativa. 


\section{Da declaração de consentimento livre e esclarecido}

$\mathrm{Eu}$,

RG declaro que tive tempo suficiente para ler e entender as informações acima. Declaro também que fui devidamente informado(a) pela pesquisadora Danielle Novais Uchôa, sobre os procedimentos, os desconfortos e riscos envolvidos, os beneficios, o custo/reembolso dos participantes e a confidencialidade da pesquisa. Confirmo que a linguagem técnica utilizada neste documento foi satisfatoriamente esclarecida e que recebi respostas para todas as minhas dúvidas. Declaro ainda que me foi assegurado que posso retirar meu consentimento a qualquer momento, sem que isso leve a qualquer penalidade ou perda de beneficios. Confirmo ainda que recebi uma cópia fidedigna deste Termo de Consentimento Livre e Esclarecido.

Dou meu consentimento de espontânea vontade e sem reservas para participar deste estudo.

Assinatura do participante:

Local: Data:

Eu, Danielle Novais Uchôa, RG 13.295-305 SSPMG, CPF 083.576.066-95, atesto que expliquei a natureza e o objetivo deste estudo, os possiveis riscos e beneficios da participação na pesquisa. Acredito que o participante recebeu todas as informações necessárias em linguagem adequada e compreensivel, e que 0 participante as compreendeu.

Assinatura do pesquisador:

Assinatura do orientador:

Local: Data: 


\section{ANEXO VII}

Estímulos usados nos experimentos 3 e 4

\section{Experimento 3}

\section{Relativas de Sujeito}

\section{Curta Resumptivo (C1) /Lacuna (C4) \\ 1. Eu / reconheci /o supervisor/que /(ele) / recebeu /um prêmio importante. \\ 2.Eu/fotografei/a cantora/que /(ela) / divulgou /a música nova. \\ 3.Eu/aplaudi/ a médica/ que/(ela) /evitou/a infecção generalizada.}

\section{Eu/conheci/o} bombeiro/ que/(ele) / inalou/ a fumaça tóxica.

\section{Eu/contratei/a} recreadora/que/(ela)/ animou/o aniversário infantil.

$$
\begin{gathered}
\text { 6.Eu/entrevistei/o } \\
\text { procurador/que/(ele)/ } \\
\text { aceitou/a denúncia } \\
\text { anônima. }
\end{gathered}
$$

7.Eu/ visitei/ a religiosa/que/(ela)/promo veu/ um bazar beneficente.

\section{Média Resumptivo (C2) /Lacuna (C5) \\ $\mathrm{Eu} /$ reconheci / o supervisor /que / na semana passada/ (ele) / recebeu / um prêmio importante.}

Eu/fotografei/a cantora /que/ na véspera do show/(ela) / divulgou / a música nova.

\section{Eu/aplaudi/a médica /que /depois do} acidente/ (ela) /evitou/

$$
\begin{gathered}
\text { a infecção } \\
\text { generalizada. }
\end{gathered}
$$

$\mathrm{Eu} /$ conheci/ o bombeiro/que/durante a enchente/ (ele) /inalou/

$$
\text { a fumaça tóxica. }
$$

\section{$\mathrm{Eu} /$ contratei/ a} recreadora/que/no final

de semana/ (ela)/ animou/ o aniversário infantil.

$$
\begin{gathered}
\text { Eu/ entrevistei/o } \\
\text { procurador/que/na } \\
\text { semana passada/ (ele)/ } \\
\text { aceitou/a denúncia } \\
\text { anônima. }
\end{gathered}
$$

$\mathrm{Eu} /$ visitei/ a religiosa/que/durante o inverno/(ela)/promoveu / um bazar beneficente.

\section{Longa Resumptivo \\ (C3)/Lacuna (C6)}

$\mathrm{Eu} / \mathrm{reconheci/o}$ supervisor/que / na semana passada/na festa da empresa /(ele) /recebeu /um prêmio importante.

Eu/fotografei/a cantora / que/ na véspera do show/do quarto do hotel/ (ela) / divulgou / a música nova

Eu/aplaudi/a médica /que /depois do acidente/dentro da ambulância /(ela) / evitou /a infecção generalizada.

Eu/conheci/o bombeiro/ que/durante o incêndio/no centro da cidade /(ele)/ inalou/a fumaça tóxica.

Eu/contratei/ a recreadora/ que / no final de semana/ no parque ecológico /(ela)/ animou/ o aniversário infantil.

Eu/ entrevistei/o procurador/ que/na semana passada/ no ministério público/ (ele)/ aceitou/ a denúncia anônima.

$\mathrm{Eu} /$ visitei/ a religiosa/que/durante o inverno/no pátio da igreja/(ela)/ promoveu/um bazar beneficente.

\section{Perguntas de compreensão}

\section{O supervisor foi} premiado?

A música divulgada era conhecida?

A médica provocou a infecção?

O bombeiro inalou a fumaça tóxica?
O procurador ignorou a denúncia?

\section{A festa teve recreadora?}

bazar era beneficente? 


\begin{tabular}{c}
\hline 8.Eu/entrevistei/o \\
estagiário/que/(ele)/ \\
descobriu / a transação \\
fraudulenta.
\end{tabular}

9.Eu/agradeci/o jogador/que/(ele)/leiloou/ as chuteiras usadas.

\section{Eu / critiquei / a psicóloga /que/ (ela)/ cancelou/ os} atendimentos agendados.

\begin{abstract}
11.Eu/elogiei/ o investigador/ que/ (ele)/descobriu/o dinheiro escondido.
\end{abstract}

\section{Eu/investiguei/ o criminoso/ que/ (ele) / cometeu / o crime perfeito.}

\section{Eu/parabenizei/ a médica/que/ (ela)/ receitou/o medicamento barato.}

14.Eu/acompanhei/a voluntária/que/(ela)/ divulgou/o projeto social.

\section{Eu/incentivei/o} blogueiro /que/ (ele)/ estreou/ um aplicativo novo.

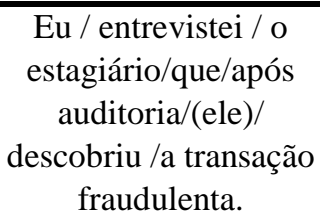

Eu/agradeci/o

jogador/que/no final da

partida/(ele)/ leiloou/

as chuteiras usadas.

Eu / critiquei / a psicóloga /que/no retorno das férias/ (ela)/ cancelou/

os atendimentos agendados.

\section{Eu/elogiei/ o} investigador/ que/

depois de vários anos/ (ele)/ descobriu/o dinheiro escondido.

Eu/investiguei/ o criminoso/ que/ durante o almoço/(ele) / cometeu /o crime perfeito.

Eu/parabenizei/ a médica/ que/após as reclamações/(ela)/receit ou/o medicamento barato.

Eu/acompanhei/a voluntária/que/ao longo da semana/ (ela)/ divulgou/o projeto social.

\section{Eu/incentivei/o} blogueiro /que/ após muitos pedidos/ (ele)/ estreou/ um aplicativo novo.

Eu/lancei/ a escritora/ que/no começo das férias/(ela)/ estreou/
$\mathrm{Eu} /$ entrevistei / o

estagiário / que /após auditoria/nas contas da empresa/ (ele) / descobriu / a transação fraudulenta.

O estagiário cometeu uma fraude?

O jogador jogou fora a chuteira? jogo/beneficente /(ele)/ leiloou/as chuteiras usadas.

Eu / critiquei / a psicóloga / que /no retorno das

férias/ no posto de saúde/ (ela)/ cancelou / os atendimentos agendados.

Eu/elogiei/ o investigador/ que/depois de vários anos/ no terraço da casa/(ele)/ descobriu/ o dinheiro

escondido.

Eu/investiguei/ o

criminoso/ que/durante o almoço /dentro do

O crime teve erros?

A psicóloga cumpriu com a agenda de atendimentos?

$\mathrm{O}$ investigador encontrou 0 dinheiro? refeitório/ (ele) / cometeu / o crime perfeito.

Eu/parabenizei/ a médica/ que/após reclamações/ na farmácia do posto/ (ela)/receitou/ o medicamento barato.

Eu/acompanhei/a voluntária/ que/ ao longo da semana/ na praça da cidade/ (ela)/ divulgou/ o projeto social.

Eu/incentivei/o blogueiro /que/ após muitos pedidos/ nas redes sociais/(ele)/ estreou/ um aplicativo

novo.

A voluntária promoveu um projeto social?

O blogueiro abandonou o aplicativo novo?

Eu/lancei/ a escritora/ que/ no começo das férias/ dentro do shopping center/
O programa da escritora é voltado para adolescentes? 
um programa infantil. (ela)/ estreou/um programa infantil.

17.Eu/ indiquei/o diretor/ que/(ele)/ divulgou/uma comédia romântica.

18.Eu/critiquei/a milionária/ que/(ela)/ celebrou/ a fusão empresarial.

19.Eu/chamei/ o técnico/que/(ele)/ consertou/ o ar condicionado antigo.

20.Eu/demiti/ o contador/que/ (ele)/ apagou/os registros financeiros.

\section{Eu/recompensei/a} estagiária/que/ (ela)/ formatou/ o computador estragado.

22.Eu/ desprezei/ o porteiro/que/(ele)/descob riu/os carros arrombados.

\section{Eu/premiei/ a engenheira/ que/}

(ela)/ construiu/ um viaduto moderno.

24.Eu/processei/a advogada/que/(ela)/descu mpriu/a ordem judicial.
$\mathrm{Eu} /$ indiquei/o diretor/ que/ na semana passada/(ele)/ divulgou/uma comédia romântica.

$\mathrm{Eu} / \mathrm{critiquei/a}$ milionária/ que/após a reunião/(ela)/ celebrou/ a fusão empresarial.

Eu/chamei/ o técnico/que/durante o almoço/(ele)/ consertou/o ar condicionado antigo.

$\mathrm{Eu} / \mathrm{demiti} / \mathrm{o}$ contador/que/antes do pagamento/ (ele)/ apagou/os registros financeiros.

Eu/ recompensei/a estagiária/que/no momento de folga/ (ela)/ formatou/ o computador estragado.

Eu/ desprezei/ o porteiro/que/logo pela manhã/(ele)/descobriu/

os carros arrombados.

Eu/premiei/ a engenheira/ que/em apenas um ano/(ela)/ construiu/um viaduto moderno.

Eu/processei/a advogada/ que/depois da audiência/(ela)/ descumpriu/a ordem judicial.
$\mathrm{Eu} /$ indiquei/o diretor/ que/na semana passada/ no festival de filmes/(ele)/ divulgou/ uma comédia romântica.

Eu/ critiquei/a milionária/ que/após a reunião / na sede da empresa/(ela)/ celebrou/ a fusão empresarial.

Eu/chamei/ o técnico/que/durante o almoço/na sala da chefia/ (ele)/ consertou/o ar condicionado antigo.

Eu/demiti/ o contador/que/antes do pagamento/nos livros fiscais/ (ele)/ apagou/os registros financeiros.

$\mathrm{Eu} /$ recompensei/a estagiária/que/no momento de folga/ na sede da empresa/(ela)/ formatou/ o computador estragado.

$\mathrm{Eu} /$ desprezei/ o porteiro/que/logo pela manhã/ no portão da garagem/(ele)/descobriu/ os carros arrombados.

Eu/premiei/ a engenheira/ que/em apenas um ano/ na maior avenida/(ela)/ construiu/um viaduto moderno.

Eu/processei/a advogada/ que/depois da audiência/na calçada do fórum/(ela)/ descumpriu/a ordem judicial.
O filme divulgado era de terror?

A milionária reprovou a fusão?

$\mathrm{O}$ ar condicionado estava com defeito?

Os registros financeiros foram apagados?

$$
\begin{gathered}
\text { O computador } \\
\text { apresentava } \\
\text { defeito? }
\end{gathered}
$$

Os carros arrombados foram encontrados?

$\mathrm{O}$ viaduto construído era ultrapassado?

A advogada desobedeceu a ordem judicial? 


\section{Relativas de Objeto Direto}

\begin{tabular}{c}
\hline Curta Resumptivo (C1) \\
/Lacuna (C4) \\
1. Eu/denunciei / a \\
prisioneira / que / o \\
carcereiro / ajudou /(ela)/ \\
na fuga /da cela. \\
\\
2. Eu/visitei/ o \\
deputado/que/a \\
senadora/ofendeu/(ele)/ no \\
evento/de campanha.
\end{tabular}

3. Eu/parabenizei/ o aluno /que / a diretora /premiou/(ele)/pela nota / de matemática.

\section{Eu/indiquei/o pintor/} que/a

arquiteta/demitiu/(ele)/ da obra / do prédio.
Eu/visitei/ o deputado / que /antes das eleições/ a senadora / ofendeu /(ele)/ no evento do partido.

Eu/parabenizei/ o aluno /que / no final do semestre /a diretora / premiou/(ele)/pela nota / de matemática.

Eu/critiquei/a empresária / que /durante a audiência/ o estagiário / favoreceu /(ela)/nas acusações de assédio.

\section{Eu/ajudei/o estrangeiro/ que/ a \\ garçonete/ajudou/(ele)/ na leitura / do cardápio.}

\section{Eu/reconheci/o} compositor/que/a produtora/criticou/(ele)/por atraso / no show.

\section{Eu/encontrei/a idosa/ que/ o garoto/} derrubou/(ela)/ no chão / sem querer.
Eu/indiquei/o pintor/ que/durante uma briga/a arquiteta/demitiu/(ele)/ da obra / do prédio.

Eu/ajudei/o estrangeiro/ que/ durante o jantar/a garçonete/ ajudou/(ele)/ na leitura / do cardápio.

$\mathrm{Eu} / \mathrm{reconheci/o}$ compositor/que/ durante uma briga/ a produtora/criticou/(ele)/ por atraso / no show.

Eu/encontrei/ a idosa/ que/ durante o tumulto/ o garoto/ derrubou/(ela)/ no chão/sem querer.

\section{Longa Resumptivo \\ (C3)/Lacuna (C6)}

Perguntas de compreensão

Eu / denunciei / a prisioneira / que / no

final de semana /dentro do presídio/ o carcereiro/ ajudou /(ela)/ na fuga / da cela.

Eu/visitei/ o deputado / que /antes das eleições/na sede do partido/ a senadora/ ofendeu/(ele)/ no evento/ de campanha.

Eu/parabenizei/ o aluno /que /no final do semestre /na sala de aula /a diretora/premiou/(ele)/ pela nota / de matemática.

Eu/critiquei/a empresária /que /durante a audiência

/ na frente do juiz / o estagiário / favoreceu/(ela)/nas acusações de assédio.
Eu/indiquei/o pintor/ que/durante uma briga/dentro do escritório/a arquiteta/demitiu/(ele)/ da obra / do prédio.

Eu/ajudei/o estrangeiro/ que/ durante o jantar/dentro do restaurante/a garçonete/ ajudou/(ele)/ na leitura/ do cardápio.

Eu/reconheci/o compositor/que/durante uma briga/ dentro do camarim/ a produtora/criticou/(ele)/ por atraso / no show.

Eu/encontrei/ a idosa/ que/ durante o tumulto/ na estação do trem/ o
A prisioneira teve ajuda na fuga?

O deputado foi elogiado no evento de campanha?

O aluno foi premiado?

O estagiário denunciou a empresária por assédio?

O pintor foi demitido da obra?

A garçonete ajudou 0 estrangeiro?

O show atrasou?

A idosa caiu no chão? 


9. Eu/atendi/ a servidora/
que/ o aposentado/
agrediu/(ela)/com arma /
de fogo.
10. Eu/reencontrei/ a
candidata/que/o médico/
reprovou/(ela)/no
concurso/ de professor.

11. Eu/ encontrei/ o funcionário/ que /a supervisora/demitiu/(ele)/ por reclamações / dos clientes.

12. Eu/avistei/ a treinadora/ que/ o árbitro/ reprimiu/(ela)/ nas partidas / do campeonato.

13. Eu/socorri/o motoqueiro/que/a médica/internou/(ele)/ pra exames / de coração.

14. $\mathrm{Eu} / \mathrm{abracei} / \mathrm{o}$ universitário/que/a professora/aprovou/(ele)/n a seleção / de monitores.

15. Eu/conheci/a reitora/que/o formando/ elogiou/(ela)/ pela fala / de encerramento.

16. Eu/amparei/ o garoto/ que/a inspetora/ castigou/(ele)/ por falta / de uniforme.
Eu/atendi/a

servidora/que/durante a perícia/o

aposentado/agrediu/(ela)/

com arma/ de fogo.

Eu / critiquei / a

psicóloga /que/no retorno

das férias/ (ela)/

cancelou/os

atendimentos agendados.

Eu/ encontrei/ o funcionário/ que /na véspera das férias/a supervisora/demitiu/(ele) / por reclamações / dos clientes.

Eu/ avistei/ a treinadora/ que/após a confusão/ o árbitro/

reprimiu/(ela)/nas partidas / do campeonato.

Eu/socorri/o motoqueiro/que/depois do acidente/a médica/internou/(ele)/ pra exames / de coração.

Eu/ abracei/o universitário/ que/após muita pressão/a professora/ inseriu/(ele)/na seleção / de monitores.

$\mathrm{Eu} / \mathrm{conheci/a}$ reitora/que/após a formatura/o formando/ elogiou/(ela)/ pela fala / de encerramento.

$\mathrm{Eu} /$ amparei/ o garoto/ que/na hora do recreio/a inspetora/ castigou/(ele)/ por falta / de uniforme. garoto/ derrubou/(ela)/

no chão / sem querer.
Eu/atendi/a
servidora/que/durante a
perícia/na repartição pública/ o
aposentado/agrediu/(ela)/
com arma/ de fogo.

$\mathrm{Eu} / \mathrm{critiquei} / \mathrm{a}$

psicóloga / que /no

retorno das férias/ no

posto de saúde/ (ela)/

cancelou / os

A servidora foi agredida?

\section{A candidata passou no concurso?}

atendimentos agendados.

$\mathrm{Eu} /$ encontrei/ o funcionário/ que /na véspera das férias/ na sala de reuniões/ a supervisora/demitiu/(ele) /por reclamações / dos clientes.

$\mathrm{Eu} /$ avistei/ a treinadora/ que/após a confusão/ dentro do vestiário/o árbitro/ reprimiu/(ela)/ nas partidas / do campeonato.

Eu/socorri/o motoqueiro/que/depois do acidente/na piscina do clube/a médica/internou/(ele)/ pra exames do coração.

\section{A supervisora atendeu as} reclamações dos clientes?

O árbitro elogiou a treinadora?

O motoqueiro foi liberado dos exames?

$\mathrm{Eu} / \mathrm{abracei} / \mathrm{o}$ universitário/ que/após muita pressão/na direção do campus/ a professora/aprovou/(ele)/ na seleção /de monitores.

Eu/conheci/a reitora/que/após a que/na hora do recreio/na inspetora/ castigou/(ele)/ formatura/ no ginásio da faculdade/o formando/ elogiou/(ela)/ pela fala/ de encerramento.

$\mathrm{Eu} /$ amparei/ o garoto/ quadra da escola/a O garoto estava sem uniforme?

O formando elogiou a fala da reitora? por falta / de uniforme.
O universitário passou na seleção?


17. Eu/ escolhi/a

pesquisadora/que/o

biólogo/ indicou/(ela)/pra

bolsas / de estudo

18. Eu/apoiei/ o professor/ que/ a pedagoga/

criticou/(ele)/ pelas notas /

da prova.

\author{
19. Eu/ observei/ a \\ bailarina/que/o \\ cabeleireiro/ \\ arrumou/(ela)/ pra \\ apresentação / de Natal.
}

\section{Eu/ elogiei/ a noiva/ que/o cabeleireiro/ penteou/(ela)/ pra cerimônia / de casamento.}

21. Eu/atendi/o rapaz/ que/a

empregada/medicou/(ele)/ com remédio / pra febre.

22. Eu/anunciei/ o dançarino/ que/a jurada/aplaudiu/(ele)/no início / da exibição.

23. Eu/elogiei/a costureira/o consultor/desprezou/(ela)/ em público / por preconceito.

24. Eu/apoiei/a competidora/que/o avaliador/eliminou/(ela)/ por suspeita / de doping.
Eu/escolhi/a

pesquisadora/que/durante a palestra/o biólogo/ indicou/(ela)/pra bolsas / de estudo.

Eu/ apoiei/ o professor/ que/no final do semestre/a pedagoga/criticou/(ele)/ pelas notas na prova.

Eu/ observei/ a bailarina/que/antes do espetáculo/

arrumou/(ela)/ pra apresentação / de Natal.

$\mathrm{Eu/} \mathrm{elogiei/} \mathrm{a} \mathrm{noiva/}$ que/na semana passada/o cabeleireiro/ penteou/(ela)/pra cerimônia / de casamento.

Eu/atendi/o garoto/ que/ durante o natal/ a empregada/medicou/(ele) /com remédio / pra febre.

Eu/anunciei/ o dançarino/ que/durante o concurso/ a jurada/aplaudiu/(ele)/no início / da exibição.

Eu/elogiei/ a costureira/ que/ no final de semana/o consultor/desprezou/(ela) / em público / por preconceito.

Eu/apoiei/a competidora/na etapa final/que/o avaliador/eliminou/(ela)/ por suspeita / de doping.
$\mathrm{Eu} /$ escolhi/a

pesquisadora/que/durante a palestra/ na feira mundial/o biólogo/ indicou/(ela)/pra bolsas / de estudo.

Eu/ apoiei/ o professor/ que/no final do semestre/na reunião de pais/a pedagoga/criticou/(ele)/

pelas notas na prova.

Eu/ observei/ a bailarina/que/antes do espetáculo/ dentro do camarim/ o cabeleireiro/ arrumou/(ela)/ pra apresentação / de Natal.

\section{$\mathrm{Eu} /$ elogiei/ a noiva/ que/na semana passada/no ensaio de fotos/ o cabeleireiro/ penteou/(ela)/ pra cerimônia / de casamento.}

Eu/atendi/o garoto/ que/ durante o natal/ na festa de família/ a

empregada/medicou/(ele) /com remédio / pra febre.

Eu/anunciei/ o dançarino/ que/durante o concurso/no festival de dança/a

jurada/aplaudiu/(ele)/no início / da exibição.

Eu/ elogiei/a costureira/ que/ no final de semana/ no desfile de moda/ o consultor/desprezou/(ela) / em público / por preconceito.

Eu/apoiei/a competidora/que/na etapa final/na vila esportiva/ o

avaliador/eliminou/(ela)/ por suspeita / de doping.
O biólogo reprovou a pesquisadora pra bolsas de estudo?

A pedagoga elogiou $o$ professor?

O cabeleireiro atrasou a bailarina pra apresentação?

O cabelo da noiva

foi penteado?

O rapaz estava com febre?

A jurada vaiou o dançarino?

O consultor elogiou a costureira?
A competidora estava sob suspeita de doping? 


\section{Experimento 4}

\section{Relativas de Oblíquo}

\begin{tabular}{cc}
\hline Curta Resumptivo (C1) & Média Resumptivo (C2) \\
/Lacuna (C4) & /Lacuna (C5) \\
& Eu/reconheci/o \\
1. Eu/reconheci/o & candidato/que/no momento \\
candidato/que/a & da prova/a \\
professora/discutiu/(com & professora/discutiu/(com \\
ele)/sobre o edital/do & ele)/sobre/o edital. \\
concurso. &
\end{tabular}

2. Eu/critiquei/a deputada/que/o apresentador/conversou/

(com ela)/sobre as promessas/de campanha.

\author{
Eu/critiquei/a \\ deputada/que/ ao final do \\ debate/o \\ apresentador/conversou/ \\ (com ela)/sobre as \\ promessas de campanha.
}

Eu/elogiei/o

passageiro/que/na fila do embarque/a comissária/ concordou/(com ele)/sobre o atraso/no embarque.

\section{Eu/defendi/ a consumidora/que/o vendedor/conversou/}

(com ele)/sobre a entrega/do produto.

\section{Eu/contratei/a estagiária/que/ o executivo/simpatizou/ (com ela)/pela iniciativa/no trabalho.}

\section{Eu/treinei/ o} corredor/que/durante a maratona/na linha de chegada/a adversária/

(com ele)/sobre a entrega/do produto.

Eu/contratei/a estagiária/que/ após o treinamento/o executivo/simpatizou/

(com ela)/pela

$$
\begin{gathered}
\mathrm{Eu} / \text { treinei/ o } \\
\text { corredor/que/durante a } \\
\text { maratona/a } \\
\text { adversária/competiu/ (com }
\end{gathered}
$$

\section{Longa Resumptivo \\ (C3)/Lacuna (C6)}

Perguntas de

compreensão

Eu/reconheci/o

candidato/que/no

momento da prova/ na

universidade/ a

professora/discutiu/(com

ele)/sobre os critérios/ de seleção.

\section{Eu/critiquei/ a}

deputada/que/ao final do debate/ dentro do camarim/o

apresentador/conversou/

(com ela)/sobre as promessas/de campanha.

Eu/elogiei/o

passageiro/que/na fila do

embarque/no aeroporto

internacional/ a

comissária/

concordou/(com

ele)/sobre o atraso/no embarque.

Eu/defendi/ a consumidora/que/após a discussão/ na frente dos clientes/o

vendedor/conversou/ iniciativa/no trabalho.
A professora discutiu com o aluno?

$\mathrm{O}$ apresentador conversou sobre as promessas de campanha?

$$
\begin{aligned}
& \text { O embarque } \\
& \text { atrasou? }
\end{aligned}
$$

\section{A consumidora e o vendedor conversaram sobre a entrega??}

(com ele)/sobre a entrega/do produto.

Eu/contratei/a estagiária/que/ após o treinamento/ na sede da empresa/ o executivo/simpatizou/ (com ela)/pela iniciativa/no trabalho.

$$
\begin{aligned}
& \mathrm{Eu} / \text { treinei/ o } \\
& \text { corredor/que/durante a } \\
& \text { maratona/na linha de } \\
& \text { chegada/a adversária/ }
\end{aligned}
$$

\author{
O corredor \\ competiu pela \\ medalha de \\ ouro?
}




\author{
competiu/ (com ele)/pela \\ medalha/ de bronze.
7. Eu/conheci/ o delegado/ que/a suspeita/ cooperou/(com ele)/ nas investigações/do assassinato.

\section{Eu/defendi/ o cozinheiro/que/a} \\ garçonete/discutiu/ (com \\ ele)/sobre o preparo/da \\ refeição.
}

\section{Eu/aplaudi/a} enfermeira/que/o médico/ concordou/(com ela)/sobre a qualidade/ dos atendimentos.

11. Eu/escutei/a maquiadora/que/a atriz/desabafou/(com ela)/sobre o papel/na
Eu/abracei/ o cozinheiro/ que/na hora do jantar/a garçonete/discutiu/(com ele)/sobre o preparo da refeição.

Eu/aplaudi/a enfermeira/que/durante o atendimento/o médico/ concordou/(com ela)/sobre a qualidade/ dos atendimentos.

\section{Eu/agradeci/ o} empresário/que/ao longo de um ano/a voluntária/trabalhou/(com ele)/pela criação/de escolas.

Eu/escutei/a minissérie.

\section{Eu/motivei/o} candidato/que/a professora/implicou/(com ele)/pela falta/de atenção.

13. Eu/defendi/a universitária/que/o calouro/desabafou/(com ela)/sobre as atividades/do trote. atriz/desabafou/(com ela)/sobre o papel/na minissérie.

Eu/motivei/o candidato/que/na véspera da prova/a professora/implicou/(com ele)/pela falta/de atenção.

Eu/defendi/a
universitária/que/durante
reunião/o
calouro/desabafou/(com

competiu/(com ele)/pela medalha/ de bronze.

Eu/conheci/ o delegado/ que/depois da ameaça/no tribunal de justiça/a suspeita/ cooperou/(com ele)/ nas investigações/do assassinato.

Eu/defendi/ o cozinheiro/ que/na hora do jantar/dentro do restaurante/a garçonete/discutiu/(com ele)/sobre o preparo/da refeição.

Eu/aplaudi/a

enfermeira/que/durante o atendimento/ no hospital público/o médico/ concordou/(com ela)/sobre a qualidade/ dos atendimentos.

Eu/agradeci/ o empresário/que/ao longo de um ano/na instituição de caridade/a voluntária/trabalhou/ (com ele)/pela criação/de escolas.

Eu/escutei/a maquiadora/que/durante a filmagem/dentro do camarim/a atriz/desabafou/(com ela)/sobre o papel/na minissérie.

A garçonete e o cozinheiro discutiram?

O médico concordou com a enfermeira?

$$
\begin{aligned}
& \text { A voluntária } \\
& \text { ajudou o } \\
& \text { empresário na } \\
& \text { criação de } \\
& \text { escolas? }
\end{aligned}
$$

A atriz comemorou com a

Eu/motivei/o candidato/que/na véspera da prova/ na sala de aula/a professora/implicou/ (com ele)/pela falta/da atenção.

Eu/defendi/a universitária/que/durante reunião/no grêmio estudantil/o calouro/desabafou/
A professora elogiou o candidato?

O calouro desabafou com a professora sobre o trote? 
ela)/sobre as atividades/do trote.

14. Eu/elogiei/a advogada/que/a consumidora/antipatizou/

(com ela)/pela demora/no atendimento.

15. Eu/repreendi/o aluno/que/ a professora/dialogou/

(com ele)/sobre a matéria/ da recuperação.

16. Eu/defendi/o caminhoneiro/que/a empresária/debateu/

(com ele)/sobre o preço/do combustível.
18. Eu/incentivei/a pintora/que/o colecionador/combinou/

(com ela)/sobre a compra/dos quadros.

19. Eu/apoiei/a consumidora/que/o técnico/discutiu/(com ela)/sobre o conserto/do equipamento.

\section{Eu/critiquei/o} promotor/ que/ a defensora/compactuou/

(com ele)/ sobre a motivação/do assalto.

(com ela)/sobre as atividades/do trote.

$$
\begin{gathered}
\text { Eu/elogiei/a } \\
\text { advogada/que/durante } \\
\text { audiência/a } \\
\text { consumidora/antipatizou/ } \\
\text { (com ela)/pela demora/no } \\
\text { atendimento. }
\end{gathered}
$$

Eu/repreendi/o aluno/que/ no final da aula/a professora/dialogou/

(com ele)/sobre a matéria/ da recuperação

Eu/defendi/o caminhoneiro/que/no retorno da greve/a empresária/debateu/

(com ele)/sobre o preço/do combustível.

Eu/admirei/o invasor/que/durante a guerra/a inimiga/batalhou/(com ele)/pela conquista/de território.

Eu/incentivei/a pintora/que/no festival de cultura/o

colecionador/combinou/

(com ela)/sobre a compra/dos quadros.

Eu/apoiei/a consumidora/que/na hora da entrega/o técnico/discutiu/(com ela)/sobre o conserto/do equipamento.

Eu/critiquei/o promotor/ que/ durante audiência/a defensora/compactuou/

(com ele)/ sobre a motivação/do assalto.
Eu/elogiei/a advogada/que/durante audiência/no juizado especial/a consumidora/antipatizou/ (com ela)/pela demora/no atendimento.

Eu/repreendi/o aluno/que/ no final da aula/na sala da direção/a professora/dialogou/

(com ele)/sobre a matéria/ da recuperação.

Eu/defendi/o caminhoneiro/que/no retorno da greve/no posto de gasolina/a empresária/debateu/(com ele)/sobre o preço/do combustível.

Eu/admirei/o invasor/que/durante a guerra/no campo de batalha/a inimiga/batalhou/(com ele)/pela conquista/de território.

Eu/incentivei/a pintora/que/no festival de cultura/na galeria de arte/o

colecionador/combinou/

(com ela)/sobre a compra/dos quadros.

Eu/apoiei/a consumidora/que/na hora da entrega/na assistência técnica/o técnico/discutiu/(com ela)/sobre o conserto/do equipamento.

\section{$\mathrm{Eu} /$ critiquei/o promotor/ que/ durante audiência/no fórum criminal/a defensora/compactuou/}

A consumidora elogiou a advogada pelo atendimento?

A professora dialogou com o aluno?

\section{A empresária argumentou com o} caminhoneiro sobre o salário?

A inimiga e o invasor disputaram território?

A pintora $\mathrm{e}$ colecionador discordaram sobre a compra dos quadros?

\section{$\mathrm{O}$ equipamento estava no conserto?}
A defensora compactuou com o promotor sobre a motivação do assalto? 
(com ele)/ sobre a motivação/do assalto.

21. Eu/ofendi/ a deputada/que/o adversário/debateu/(com ela)/pela aprovação/ do projeto.

22. Eu/apoiei/a

farmacêutica/que/o enfermeiro/discordou/(com ela)/sobre a campanha/ de vacinação.

23. Eu/indiquei/o corregedor/ que/a prisioneira/desabafou/(com ela)/sobre os problemas/do presídio.

24. Eu/indiquei/o coordenador/que/a aluna/desabafou/(com ele)/ sobre as dificuldades /de aprendizado.
Eu/ofendi/ a

deputada/que/no final do mandato/o

adversário/debateu/(com ela)/pela aprovação/ do projeto.

\section{Eu/apoiei/a}

farmacêutica/que/durante muitos anos/o

enfermeiro/discordou/(com ela)/sobre a campanha/ de vacinação.

Eu/indiquei/o corregedor/ que/depois da rebelião/a prisioneira/desabafou/(com ela)/sobre os problemas/do presídio.

\section{Eu/indiquei/o}

coordenador/que/depois da prova/a

aluna/desabafou/(com ele)/ sobre as dificuldades /de aprendizado.
Eu/ofendi/ a

deputada/que/no final do mandato/no congresso nacional/o

adversário/debateu/com ela)/pela aprovação/ do projeto.

Eu/apoiei/a

farmacêutica/que/durante muitos anos/no posto de saúde/o

enfermeiro/discordou/

(com ela)/sobre a campanha/ de vacinação.

Eu/indiquei/o corregedor/ que/depois da rebelião/dentro da delegacia/a prisioneira/desabafou/

(com ela)/sobre os problemas/do presídio.

Eu/indiquei/o coordenador/que/depois da prova/na sala da direção/ a aluna/desabafou/(com ele)/ sobre as dificuldades /de aprendizado.
Houve um debate pela aprovação do projeto?

O enfermeiro e a farmacêutica discordaram sobre a campanha de vacinação?

A prisioneira desabafou sobre os problemas do presídio?

A aluna reclamou com o coordenador?

\section{Relativas de Genitivo}

Curta Resumptivo (C1)
/Lacuna (C4)
1. Eu / reconheci / a
jogadora / que /o adversário
/(dela)/ atendeu /a imprensa
local.
2. Eu/ajudei/o aposentado /
que /antes do jantar/ a
cuidadora /(dele)/ aplicou /o
remédio incorreto.
Média Resumptivo (C2) /Lacuna (C5)

$\mathrm{Eu} /$ reconheci / a jogadora / que /no final da partida /o adversário /(dela)/ atendeu /a imprensa local.

Eu/ajudei/o aposentado/que /antes do jantar / a cuidadora

\section{Longa Resumptivo (C3)/Lacuna (C6) \\ $\mathrm{Eu} / \mathrm{reconheci} / \mathrm{a}$ jogadora / que /no final da partida /dentro do vestiário/ o adversário /(dela)/ atendeu /a imprensa local.}

\section{Perguntas de compreensão}

Eu/ajudei/o aposentado / que /antes do jantar / na casa de repouso/ a cuidadora /(dele)/
O adversário atendeu a imprensa?

A cuidadora acertou no remédio? 


3. Eu/critiquei/a atriz /que /o
cabeleireiro/(dela)/ escolheu
/o penteado errado.
4. Eu/processei/ o
empresário /que /a
contadora/(dele)/acessou
/documentos sigilosos.
5. Eu/consolei/a noiva/ que/o

fotógrafo/(dela)/deletou/ as fotos arquivadas.

6. Eu/apoiei/o redator/que/a editora/(dele)/publicou/as notícias falsas.

Eu/processei/ o empresário

7. Eu/elogiei/ a professora/que/o aluno/(dela)/divulgou/um livro infantil.

\section{Eu/abracei/o} nadador/que/a treinadora/(dele)/ recebeu/ um prêmio internacional.

9. Eu/visitei/a idosa/que/o enfermeiro/(dela)/descumpri u/ordens médicas.

10. Eu/contratei /o advogado/que/a estagiária/(dele)/ignorou/

os prazos judiciais. um prêmio internacional. /(dele)/ aplicou /o remédio incorreto.

$\mathrm{Eu} / \mathrm{critiquei} / \mathrm{a}$ atriz /que /na estreia do filme /o cabeleireiro/(dela)/ escolheu /o penteado errado. /que /no início do dia/ a contadora/(dele) /acessou /documentos sigilosos.
Eu/consolei/a noiva/ que/no final da cerimônia/o fotógrafo/(dela)/deletou/ as fotos arquivadas.

Eu/apoiei/o redator /que/durante revisão/a editora/(dele)/publicou/as notícias falsas.

Eu/elogiei/ a

aplicou /o remédio incorreto.

$\mathrm{Eu} / \mathrm{critiquei/a}$ atriz /que /na estreia do filme /na festa de lançamento/ o cabeleireiro/(dela)/ escolheu /o penteado errado.

\section{Eu/processei/ o} empresário /que /no início do dia/ na sede da empresa/ a contadora/ (dele) /acessou /documentos sigilosos.

\section{Eu/consolei/a noiva/ que/no final da cerimônia/no salão da igreja/o}

fotógrafo/(dela)/deletou/ as fotos arquivadas.

Eu/apoiei/o redator /que/durante revisão/na redação do jornal/a editora/(dele)/publicou/a s notícias falsas. professora/que/na semana passada/o aluno/(dela)/divulgou/um livro infantil.

Eu/abracei/o

nadador/que/após a competição/a treinadora/(dele)/ recebeu/

\author{
$\mathrm{Eu} / \mathrm{visitei} / \mathrm{a}$ \\ idosa/que/durante \\ tratamento/o
} enfermeiro/(dela)/descump riu/ordens médicas.

$\mathrm{Eu} /$ contratei /o advogado/que/durante o processo/a estagiária/(dele)/ignorou/ os prazos judiciais.
Eu/elogiei/ a professora/que/na semana passada/na feira literária/o

aluno/(dela)/divulgou/um livro infantil.

Eu/abracei/o nadador/que/após a competição/no ginásio do clube/a treinadora/(dele)/ recebeu/ um prêmio internacional.

$\mathrm{Eu} / \mathrm{visitei} / \mathrm{a}$ idosa/que/durante tratamento/na enfermaria do hospital/o enfermeiro/(dela)/descu mpriu/ordens médicas.

Eu/contratei /o advogado/que/durante $o$ processo/no fórum criminal/a estagiária/(dele)/ignorou/ os prazos judiciais.
O penteado escolhido foi adequado?

A contadora acessou documentos secretos?

O fotógrafo apagou as fotos?

A editora publicou notícias falsas?

O livro divulgado era para adultos?

A treinadora foi premiada?

O enfermeiro cumpriu ordens médicas?

A estagiária cumpriu os prazos? 


\begin{tabular}{|c|c|}
\hline $\begin{array}{c}\text { 11. Eu/encontrei/o } \\
\text { executivo/que/a } \\
\text { secretária/(dele)/cancelou/ as } \\
\text { palestras agendadas. }\end{array}$ & $\begin{array}{c}\text { Eu/encontrei/o } \\
\text { executivo/que/no início da } \\
\text { semana/a } \\
\text { secretária/(dele)/cancelou/ } \\
\text { as palestras agendadas. }\end{array}$ \\
\hline $\begin{array}{l}\text { 12. Eu/adverti/a } \\
\text { convidada/que/o } \\
\text { tradutor/(dela)/cometeu/ } \\
\text { erros gravíssimos. }\end{array}$ & $\begin{array}{c}\text { Eu/adverti/a } \\
\text { convidada/que/durante a } \\
\text { palestra/o } \\
\text { tradutor/(dela)/cometeu/ } \\
\text { erros gravíssimos. }\end{array}$ \\
\hline $\begin{array}{c}\text { 13. Eu/conheci/o } \\
\text { freguês/que/a } \\
\text { cabeleireira/(dele)/empregou } \\
\text { /uma técnica nova. }\end{array}$ & $\begin{array}{c}\text { Eu/conheci/o } \\
\text { freguês/que/durante } \\
\text { atendimento/ a } \\
\text { cabeleireira/(dele)/empreg } \\
\text { ou/uma técnica nova. }\end{array}$ \\
\hline $\begin{array}{c}\text { 14. Eu/acusei/o } \\
\text { professor/que/a } \\
\text { monitora/(dele)/corrigiu/os } \\
\text { trabalhos finais. }\end{array}$ & $\begin{array}{c}\text { Eu/acusei/o } \\
\text { professor/que/em pouco } \\
\text { tempo/ a } \\
\text { monitora/(dele)/corrigiu/os } \\
\text { trabalhos finais. }\end{array}$ \\
\hline
\end{tabular}

15. Eu/defendi/o

fazendeiro/ que/a

empregada/(dele)/exigiu/um salário melhor.

16. Eu/aplaudi/o goleiro/que/o treinador/(dele)/ preparou/um treino pesado.

\section{Eu/acompanhei/a cantora/que/o} assessor/(dela)/cancelou/a turnê internacional.

18. Eu/ajudei/o convidado/que/a anfitriã/(dele)/reservou/o hotel errado.
Eu/encontrei/o

executivo/que/no início

da semana/na sede da empresa/a

secretária/(dele)/cancelo $\mathrm{u} /$ as palestras agendadas.

Eu/adverti/a convidada/que/durante a palestra/ na feira internacional/o tradutor/(dela)/cometeu/

erros gravíssimos.

\section{Eu/conheci/o}

freguês/que/durante atendimento/no salão de beleza/a

cabeleireira/(dele)/empre gou/uma técnica nova.

\section{Eu/acusei/o}

professor/que/em pouco tempo/na sala da faculdade/a monitora/(dele)/corrigiu/ os trabalhos finais.

Eu/defendi/o fazendeiro/ que/ no retorno das férias/ a empregada/(dele)/exigiu/

um salário melhor.

$$
\begin{gathered}
\text { Eu/aplaudi/o } \\
\text { goleiro/que/durante a } \\
\text { competição/ a } \\
\text { treinadora/(dele)/ } \\
\text { preparou/um treino pesado. }
\end{gathered}
$$

Eu/acompanhei/a cantora/que/na véspera do show/ o assessor/(dela)/cancelou/a turnê internacional.

$$
\text { Eu/ajudei/o }
$$

convidado/que/durante a viagem/ a

anfitriã/(dele)/reservou/o hotel errado.
Eu/defendi/o fazendeiro/ que/ no retorno das férias/na sede da fazenda/a empregada/(dele)/exigiu/

um salário melhor.

Eu/aplaudi/o goleiro/que/durante a competição/no centro de treinamento/a treinadora/(dele)/ preparou/um treino pesado.

Eu/acompanhei/a cantora/que/na véspera do show/no quarto do hotel/o assessor/(dela)/cancelou/ a turnê internacional.

Eu/ajudei/o convidado/que/durante a viagem/no litoral brasileiro/a A empregada exigiu férias?

A secretária cancelou as palestras?

O tradutor cometeu erros gravíssimos?

A massagista utilizou técnica nova?

A monitora corrigiu os trabalhos?

O treino do goleiro era pesado?

O assessor da cantora manteve a turnê?

A anfitriã reservou o hotel correto? 


\begin{tabular}{|c|c|c|c|}
\hline & & $\begin{array}{l}\text { anfitriã/(dele)/reservou/o } \\
\text { hotel errado. }\end{array}$ & \\
\hline $\begin{array}{c}\text { 19. Eu/conheci/a } \\
\text { noiva/que/o } \\
\text { costureiro/(dela)/sugeriu/o } \\
\text { vestido perfeito. }\end{array}$ & $\begin{array}{c}\mathrm{Eu} / \text { conheci/a noiva/que/na } \\
\text { primeira visita/ o } \\
\text { costureiro/(dela)/sugeriu/o } \\
\text { vestido perfeito. }\end{array}$ & $\begin{array}{c}\text { Eu/conheci/a } \\
\text { noiva/que/na primeira } \\
\text { visita/no ateliê de } \\
\text { costura/o } \\
\text { costureiro/(dela)/sugeriu/ } \\
\text { o vestido perfeito. }\end{array}$ & $\begin{array}{l}\text { O costureiro } \\
\text { sugeriu o } \\
\text { vestido } \\
\text { errado? }\end{array}$ \\
\hline $\begin{array}{c}\text { 20. Eu/abracei/a } \\
\text { bancária/que/o } \\
\text { sequestrador/(dela)/aceitou/o } \\
\text { acordo policial. }\end{array}$ & $\begin{array}{c}\text { Eu/abracei/a } \\
\text { bancária/que/depois de } \\
\text { muitas horas/ o } \\
\text { sequestrador/(dela)/aceitou } \\
\text { /o acordo policial. }\end{array}$ & $\begin{array}{c}\text { Eu/abracei/a } \\
\text { bancária/que/depois de } \\
\text { muitas horas/dentro do } \\
\text { cativeiro/o } \\
\text { sequestrador/(dela)/aceit } \\
\text { ou/o acordo policial. }\end{array}$ & $\begin{array}{l}\mathrm{O} \\
\text { sequestrador } \\
\text { recusou o } \\
\text { acordo? }\end{array}$ \\
\hline $\begin{array}{c}\text { 21. Eu/acusei/o } \\
\text { detento/que/a } \\
\text { defensora/(dele)/conseguiu/a } \\
\text { prisão domiciliar. }\end{array}$ & $\begin{array}{c}\text { Eu/acusei/o } \\
\text { detento/que/logo depois da } \\
\text { prisão/ a } \\
\text { defensora/(dele)/conseguiu } \\
\text { /a prisão domiciliar. }\end{array}$ & $\begin{array}{c}\text { Eu/acusei/o } \\
\text { detento/que/logo depois } \\
\text { da prisão/na audiência de } \\
\text { custódia/a } \\
\text { defensora/(dele)/ } \\
\text { conseguiu/a prisão } \\
\text { domiciliar. }\end{array}$ & $\begin{array}{l}\text { A defensora } \\
\text { conseguiu } \\
\text { prisão } \\
\text { domiciliar? }\end{array}$ \\
\hline $\begin{array}{c}\text { 22. Eu/critiquei/a } \\
\text { milionária/que/o } \\
\text { mordomo/(dela)/preparou/ } \\
\text { um jantar requintado. }\end{array}$ & $\begin{array}{c}\text { Eu/critiquei/a } \\
\text { milionária/que/no final de } \\
\text { semana/o } \\
\text { mordomo/(dela)/preparou/ } \\
\text { um jantar requintado. }\end{array}$ & $\begin{array}{c}\text { Eu/critiquei/a } \\
\text { milionária/que/no final } \\
\text { de semana/na casa de } \\
\text { veraneio/o } \\
\text { mordomo/(dela)/ } \\
\text { preparou/ } \\
\text { um jantar requintado. }\end{array}$ & $\begin{array}{l}\text { O jantar era } \\
\text { sofisticado? }\end{array}$ \\
\hline $\begin{array}{c}\text { 23. Eu/defendi /a } \\
\text { lutadora/que/o } \\
\text { adversário/(dela)/aplicou/um } \\
\text { a técnica infalível. }\end{array}$ & $\begin{array}{c}\text { Eu/defendi /a } \\
\text { lutadora/que/durante o } \\
\text { concurso/ o } \\
\text { adversário/(dela)/aplicou/u } \\
\text { ma técnica infalível. }\end{array}$ & $\begin{array}{c}\text { Eu/defendi /a } \\
\text { lutadora/que/durante o } \\
\text { concurso/na frente da } \\
\text { plateia/o } \\
\text { adversário/(dela)/aplicou } \\
\text { /uma técnica infalível. }\end{array}$ & $\begin{array}{c}\text { A técnica era } \\
\text { infalível? }\end{array}$ \\
\hline $\begin{array}{c}\text { 24. Eu/avaliei/a } \\
\text { universitária/que/o } \\
\text { orientador } \\
\text { /(dela)/recebeu/um prêmio } \\
\text { importante. }\end{array}$ & $\begin{array}{c}\text { Eu/avaliei/a } \\
\text { universitária/que/no final } \\
\text { do evento/ o orientador } \\
\text { /(dela)/recebeu/um prêmio } \\
\text { importante. }\end{array}$ & $\begin{array}{c}\text { Eu/avaliei/a } \\
\text { universitária/que/no final } \\
\text { do evento/na feira } \\
\text { científica/o orientador } \\
\text { /(dela)/recebeu/um } \\
\text { prêmio importante. }\end{array}$ & $\begin{array}{l}\text { O orientador } \\
\text { foi criticado? }\end{array}$ \\
\hline
\end{tabular}

\section{Distratoras}

\section{Sentenças}

1

$\mathrm{Eu} /$ reconheci/ que/ na semana passada/ em uma praia deserta/ fotografei/ uma modelo /sem permissão.

Perguntas de compreensão A modelo me permitiu fotografá-la? 
2 Eu / descobri/ que/ a matéria publicada/ na semana passada/ sobre o leilão/ era
falsa.

3

Eu / assumi/ que /o comentário/ na página da empresa/ causou/ um mal estar desnecessário

4 Ew/

Eu/ considerei/ que/no último final de semana/ na feira de adoção/ a

veterinária/maltratou/ os animais abandonados.

$5 \mathrm{Eu} /$ ponderei/ que/ o acusado do crime/poderia/ contribuir / com a polícia/nas investigações.

6

$\mathrm{Eu} /$ concordei/ que/ a comissária/ cometeu/ um erro/ ao se recusar/ a ajudar/ o passageiro/ com as bagagens.

$7 \mathrm{Eu} /$ indiquei/que/ na última reunião com os clientes/o diretor/demonstrou/ insegurança/ na apresentação dos resultados.

8 Eu/afirmei/ que/ depois da confusão/ na saída do estádio/a torcida/ receberia/ uma punição/ do clube.

$9 \mathrm{Eu} /$ confirmei/ que/ durante a prova/ o candidato/consultou/ a fiscal/ sem autorização.

10

$\mathrm{Eu} /$ analisei/ que/o candidato/ estava/ desconfortável/ durante o debate/com os outros candidatos.

11

$\mathrm{Eu} /$ confirmei/que/a teoria defendida/ pelo renomado pesquisador/ estava/errada.

12

Eu/ argumentei/ que/o critério utilizado/ para contratação/ de estagiários/ era injusta.

13

Eu e meu amigo/observamos/ que/ durante a viagem/ na estrada perigosa/ o motorista/ dormiu/ no volante.

14

Eu e a professora/ concordamos/ que/ durante a apresentação/no congresso internacional/a palestrante/rebateu/as críticas/com maestria.

15

Eu e o motorista/ percebemos/ que/ durante todo o trajeto/ pra casa/fomos seguidos/ por um carro.
A matéria

publicada era

falsa?

O comentário na página da empresa trouxe satisfação?

A veterinária maltratou os animais?

O acusado poderia ajudar nas

investigações?

A comissária recusou ajuda ao passageiro?

O diretor parecia inseguro na apresentação?

Teve confusão na saída do estádio?

O fiscal autorizou a consulta do candidato?

Teve debate entre os candidatos?

A teoria do renomado pesquisador estava certa?

O critério de contratação era justo?

O motorista dormiu enquanto dirigia?

A palestrante soube rebater as críticas?

Um carro nos seguiu durante o percurso? 
Eu e minha amiga/ avaliamos/ que/ o churrasco de confraternização/ da escola/ foi mal organizado.

17

Eu e minha secretária/ combinamos/ que/ por conta do feriado prolongado/ a agenda da semana/ seria cancelada.

18

Eu e a psicóloga/ decidimos/ que/ a partir do próximo mês/a terapia/ ocorrerá/ quinzenalmente.

19

Eu e o palestrante / definimos/ que/ uma vez por mês/ no auditório da faculdade/ haverá/ debates/ de assuntos atuais.

20

Eu e a promotora/ concluímos/ que/ diante das provas coletadas/ no local do crime/ o suspeito/ é inocente das acusações.

21

Eu e o coordenador/ acordamos/ que/o projeto social/deverá receber/ patrocínio/para continuar.

22

Eu e o policial/ testemunhamos/ que/ a vítima/ omitiu/ fatos/ em depoimento/ na delegacia/ após o flagrante.

23

Eu e o vizinho/ propusemos/que/ os moradores/ assinem/ um abaixo-assinado/ com as reclamações/ sobre o síndico.

24

Eu e a empregada/denunciamos/que/ o milionário/ descumpriu/com acordos trabalhistas.

25

O deputado/ admitiu /que/ quando interrogado/ na delegacia/ mentiu /em depoimento.

26

A milionária/pediu/que/ em apenas 30 minutos/ o mordomo/ organizasse/ um jantar/ para os convidados.

O torcedor/ afirmou/ que/depois do jogo/ em uma churrascaria/ a treinadora/ impediu/ a torcida /de fotografar/ os jogadores. A secretária/anunciou/ que/o médico/cancelou/os atendimentos/ por motivo de saúde.

29 O suspeito/reforçou/ que/ no momento/ do crime/ estava/ trabalhando.

30 A vereadora/ exigiu/ que/ o prefeito/cumpra/ as promessas/ de campanha.
O churrasco era

de

confraternização?

A agenda foi cancelada?

A terapia ocorrerá toda semana?

Os debates serão de temas atuais?

O suspeito é culpado pelo crime?

O projeto poderá continuar sem patrocínio?

A vítima contou tudo que sabia após o flagrante?

Os moradores têm reclamações contra o síndico?

O milionário cumpriu com acordos trabalhistas?

O deputado falou a verdade no depoimento?

O mordomo deveria organizar um jantar?

A treinadora deixou fotografarem os jogadores?

O médico manteve os atendimentos?

O suspeito afirmou estar trabalhando?

A vereadora quer que o prefeito cumpra as promessas? 
31

32

A empresária/ assumiu/ durante a fiscalização/nas lojas da cidade/ que/ repassou/ mercadorias falsificadas/ aos clientes.

33 O médico/ perguntou/ que injeção/a enfermeira/aplicou/ no paciente/ em estado grave.

34

A cliente/ questionou/ que estratégia de defesa/ a advogada/ utilizou/ no processo.

35

O jogador/perguntou/que técnico/ comandará/ o time/ após a derrota/ na final do campeonato.

36

A apresentadora/ quis saber/ que horário/o seu novo programa/ será transmitido/ na emissora.

37

O gerente/ questionou/ que cardápio/ a cozinheira/ preparou/ pro jantar de gala/ dos sócios da multinacional.

38

A vereadora/ quis saber/ que recursos/ o prefeito/ utilizou/ para a construção/ da escola infantil/ na periferia da cidade.

39

O vendedor/ perguntou/ que tamanho/ de calça/ a cliente/ levaria/ de presente/para seu marido.

$40 \mathrm{O}$ técnico/ questionou/ que defeito/ o equipamento eletrônico/apresentava.

41 A síndica/ afirmou/ que/ o porteiro/ não a reconheceu/ na portaria do prédio/ ontem.

42 A jornalista/ admitiu /que/o deputado/ assediou-a/ durante uma entrevista/ no gabinete.

43

O bancário/ confessou/ que/ a criminosa/ induziu-o/ a participar/ do assalto/na semana passada.

44

O cadeirante/ declarou/ que/ a estrangeira/discriminou - o/ durante o passeio turístico.
$\mathrm{O}$ agricultor usou produtos proibidos?

A empresária comercializava produtos falsos?

O paciente está fora de perigo?

A cliente quis saber sobre a estratégia de defesa?

O time venceu a final do campeonato?

A apresentadora sabe o horário do seu novo programa?

Haverá um jantar de gala?

O prefeito usou recursos para construir uma escola infantil?

A cliente comprou um presente pro filho?

O equipamento eletrônico estava com defeito?

O porteiro reconheceu a síndica na portaria?

A jornalista entrevistou o deputado no gabinete?

O bancário participou do crime?

A estrangeira agiu com preconceito com o cadeirante? 
45 A modelo/ considerou/ que/ o estilista/ não a escolheu/para o desfile/ da grife internacional/ por ser inexperiente.

46

O motorista/disse/ que/ a policial/ multou-o/ injustamente/pelo estacionamento em local proibido/ na rodoviária.

O estilista

escolheu a

modelo

inexperiente?

O motorista recebeu uma multa?

47 A ambulante/ negou/ que/ o cliente/ insultou-a/ por ter se recusado a negociar/ o

A cliente insultou a ambulante?

O instrutor recebeu um presente da aluna? exame. 


\section{ANEXO VIII}

Organização das listas (quadrado latino)

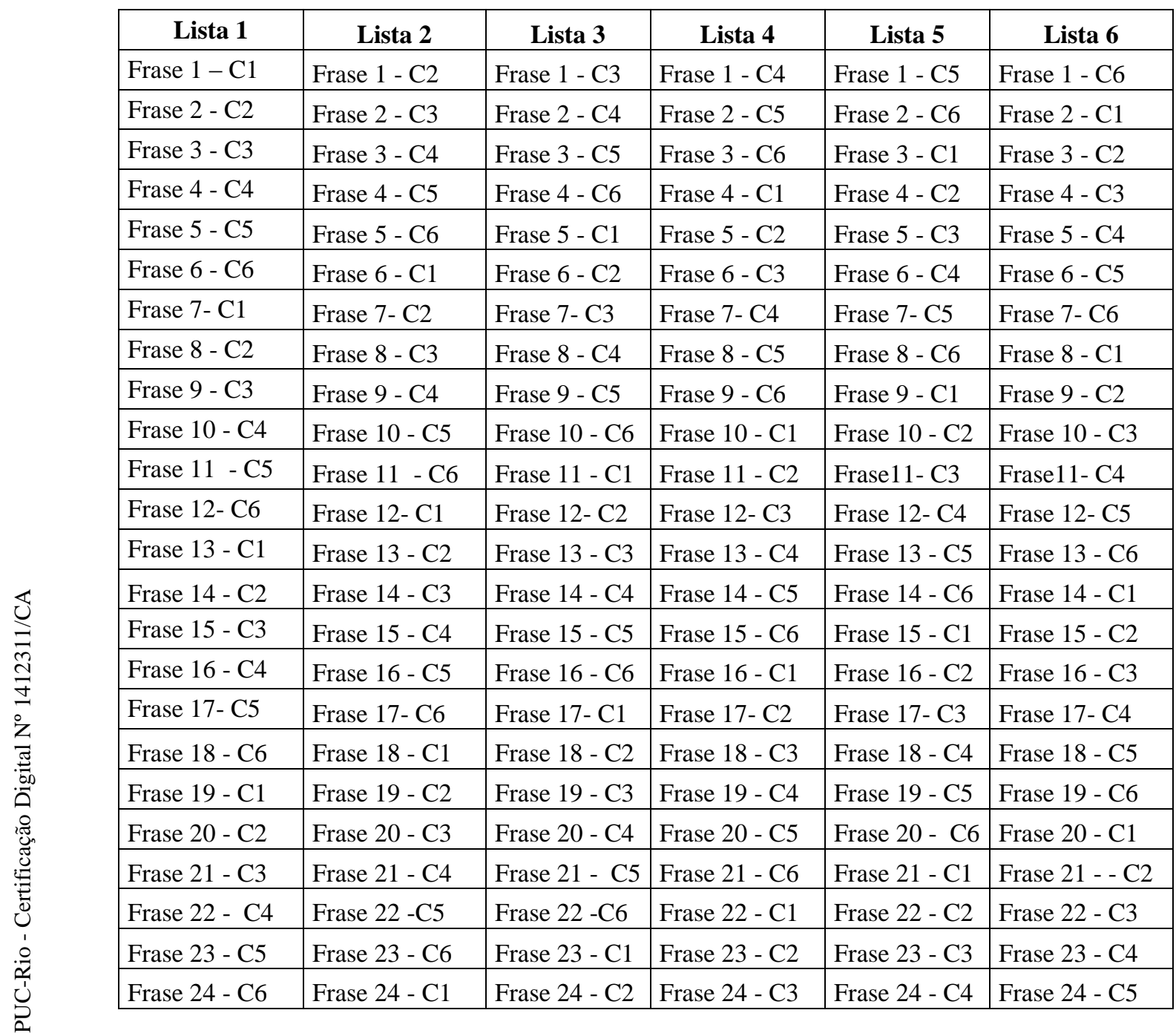




\section{ANEXO IX}

Tempos de reação por condição experimental - Experimentos 3 e 4

\section{Sujeito}

\begin{tabular}{|c|c|c|c|c|c|c|}
\hline & $\begin{array}{c}\text { Curta } \\
\text { Resumptivo } \\
\text { (C1) } \\
\end{array}$ & $\begin{array}{c}\text { Curta } \\
\text { Lacuna }(\mathrm{C4})\end{array}$ & $\begin{array}{c}\text { Média } \\
\text { Resumptivo } \\
\text { (C2) }\end{array}$ & $\begin{array}{c}\text { Média } \\
\text { Lacuna (C5) }\end{array}$ & $\begin{array}{c}\text { Longa } \\
\text { Resumptivo } \\
\text { (C3) } \\
\end{array}$ & $\begin{array}{c}\text { Longa } \\
\text { Lacuna (C6) }\end{array}$ \\
\hline 1 & 200,57 & 132,14 & 72,11 & 111,30 & 106,58 & 135,72 \\
\hline 2 & 124,20 & 137,37 & 153,92 & 47,08 & 401,60 & 483,35 \\
\hline 3 & 83,50 & 46,32 & 211,79 & 99,65 & 64,28 & 263,45 \\
\hline 4 & 134,60 & 196,06 & 125,24 & 169,63 & 209,19 & 155,66 \\
\hline 5 & 77,44 & 72,15 & 75,13 & 24,99 & 84,54 & 223,72 \\
\hline 6 & 196,74 & 359,28 & 285,85 & 238,66 & 175,13 & 252,41 \\
\hline 7 & 316,82 & 416,85 & 294,01 & 104,94 & 187,55 & 203,23 \\
\hline 8 & 82,28 & 127,87 & 71,43 & 82,39 & 175,13 & 116,25 \\
\hline 9 & 119,36 & 260,15 & 294,97 & 235,76 & 192,63 & 189,99 \\
\hline 10 & 304,68 & 281,79 & 359,59 & 320,45 & 252,12 & 237,83 \\
\hline 11 & 355,54 & 335,94 & 394,82 & 326,15 & 286,70 & 309,38 \\
\hline 12 & 98,46 & 122,28 & 140,91 & 173,80 & 119,07 & 41,30 \\
\hline 13 & 193,48 & 123,11 & 195,63 & 165,45 & 68,10 & 61,97 \\
\hline 14 & 78,80 & 179,03 & 139,23 & 124,79 & 241,76 & 216,52 \\
\hline 15 & 82,17 & 160,75 & 102,74 & 165,49 & 144,72 & 293,57 \\
\hline 16 & 96,83 & 40,27 & 111,58 & 85,95 & 85,12 & 445,49 \\
\hline 17 & 183,58 & 86,35 & 155,71 & 316,84 & 229,81 & 311,90 \\
\hline 18 & 162,28 & 304,18 & 201,09 & 355,08 & 164,39 & 264,94 \\
\hline 19 & 219,67 & 86,32 & 166,10 & 262,61 & 153,10 & 311,15 \\
\hline 20 & 91,15 & 234,37 & 73,76 & 105,31 & 69,36 & 324,23 \\
\hline 21 & 78,45 & 140,37 & 145,86 & 197,87 & 216,93 & 240,38 \\
\hline 22 & 159,68 & 173,69 & 186,28 & 142,30 & 175,95 & 274,58 \\
\hline 23 & 123,76 & 164,06 & 70,30 & 106,82 & 162,41 & 304,73 \\
\hline Médias & 154,96 & 181,77 & 175,13 & 172,32 & 172,44 & 246,16 \\
\hline
\end{tabular}


Objeto direto

\begin{tabular}{|c|c|c|c|c|c|c|}
\hline & $\begin{array}{c}\text { Curta } \\
\text { Resumptivo } \\
\text { (C1) } \\
\end{array}$ & $\begin{array}{c}\text { Curta } \\
\text { Lacuna (C4) }\end{array}$ & $\begin{array}{c}\text { Média } \\
\text { Resumptivo } \\
\text { (C2) }\end{array}$ & $\begin{array}{c}\text { Média } \\
\text { Lacuna (C5) }\end{array}$ & $\begin{array}{c}\text { Longa } \\
\text { Resumptivo } \\
\text { (C3) } \\
\end{array}$ & $\begin{array}{c}\text { Longa } \\
\text { Lacuna (C6) }\end{array}$ \\
\hline 1 & 215,51 & 238,195 & 160,64 & 290,4975 & 386,82 & 455,22 \\
\hline 2 & 191,62 & 313,785 & 310,55 & 343,9 & 438,32 & 402,73 \\
\hline 3 & 188,72 & 85,82 & 282,20 & 22,195 & 250,28 & 401,67 \\
\hline 4 & 53,80 & 69,125 & 178,73 & 184,46 & 274,71 & 209,83 \\
\hline 5 & 35,05 & 101,1925 & 204,79 & 258,5475 & 246,23 & 312,24 \\
\hline 6 & 52,89 & 98,3475 & 126,56 & 57,2275 & 203,95 & 260,00 \\
\hline 7 & 244,27 & 332,575 & 352,93 & 287,3475 & 293,20 & 313,42 \\
\hline 8 & 242,22 & 196,16 & 146,40 & 125,925 & 319,77 & 319,83 \\
\hline 9 & 111,28 & 116,005 & 60,67 & 86,0625 & 203,95 & 260,00 \\
\hline 10 & 164,91 & 84,42 & 58,68 & 109,93 & 227,91 & 356,71 \\
\hline 11 & 171,78 & 187,08 & 205,67 & 272,56 & 342,125 & 277,02 \\
\hline 12 & 115,30 & 228,5025 & 288,59 & 192,0725 & 313,23 & 326,63 \\
\hline 13 & 175,78 & 279,38 & 139,19 & 336,6425 & 421,99 & 396,54 \\
\hline 14 & 117,76 & 105,9425 & 99,34 & 362,0475 & 312,70 & 281,82 \\
\hline 15 & 217,55 & 176,2225 & 112,81 & 178,385 & 393,81 & 379,42 \\
\hline 16 & 91,60 & 251,12 & 236,775 & 273,87 & 278,80 & 440,37 \\
\hline 17 & 199,89 & 208,685 & 118,05 & 188,9375 & 235,37 & 430,425 \\
\hline 18 & 112,88 & 227,575 & 335,98 & 181,5375 & 406,63 & 441,565 \\
\hline 19 & 180,76 & 247,26 & 172,0125 & 315,895 & 253,09 & 264,7925 \\
\hline 20 & 215,59 & 294,0225 & 156,1625 & 188,9375 & 341,9275 & 273,095 \\
\hline Médias & 154,96 & 192,07 & 187,33 & 212,85 & 307,24 & 340,17 \\
\hline
\end{tabular}


Oblíquo

\begin{tabular}{|c|c|c|c|c|c|c|}
\hline & $\begin{array}{c}\text { Curta } \\
\text { Resumptivo } \\
\text { (C1) }\end{array}$ & $\begin{array}{c}\text { Curta } \\
\text { Lacuna }(\mathrm{C4})\end{array}$ & $\begin{array}{c}\text { Média } \\
\text { Resumptivo } \\
\text { (C2) }\end{array}$ & $\begin{array}{c}\text { Média } \\
\text { Lacuna (C5) }\end{array}$ & $\begin{array}{c}\text { Longa } \\
\text { Resumptivo } \\
\text { (C3) }\end{array}$ & $\begin{array}{c}\text { Longa } \\
\text { Lacuna (C6) }\end{array}$ \\
\hline 1 & 85,70 & 200,93 & 82,86 & 279,34 & 314,76 & 212,84 \\
\hline 2 & 129,68 & 167,83 & 176,80 & 162,76 & 125,39 & 287,62 \\
\hline 3 & 86,26 & 173,76 & 157,94 & 216,34 & 226,58 & 302,58 \\
\hline 4 & 90,20 & 180,98 & 109,33 & 178,16 & 335,19 & 351,92 \\
\hline 5 & 290,14 & 210,17 & 312,34 & 248,70 & 400,77 & 197,78 \\
\hline 6 & 235,20 & 135,72 & 304,27 & 288,34 & 367,82 & 316,90 \\
\hline 7 & 182,89 & 312,06 & 264,71 & 280,97 & 301,74 & 276,56 \\
\hline 8 & 343,28 & 373,86 & 332,96 & 278,05 & 433,42 & 362,70 \\
\hline 9 & 96,06 & 211,68 & 228,17 & 416,32 & 524,84 & 250,60 \\
\hline 10 & 165,93 & 164,67 & 162,62 & 310,59 & 391,93 & 427,85 \\
\hline 11 & 146,75 & 225,11 & 125,58 & 191,96 & 270,39 & 241,36 \\
\hline 12 & 217,27 & 373,22 & 209,85 & 391,06 & 262,66 & 234,27 \\
\hline 13 & 298,25 & 151,76 & 103,77 & 189,54 & 184,23 & 279,85 \\
\hline 14 & 130,64 & 224,42 & 95,43 & 210,12 & 342,98 & 243,63 \\
\hline 15 & 131,68 & 131,29 & 154,33 & 325,90 & 164,26 & 266,38 \\
\hline 16 & 94,51 & 291,74 & 157,78 & 226,62 & 321,24 & 373,07 \\
\hline 17 & 179,62 & 187,49 & 160,18 & 264,20 & 255,88 & 236,63 \\
\hline 18 & 226,74 & 251,16 & 276,63 & 402,99 & 516,57 & 425,65 \\
\hline 19 & 137,57 & 174,76 & 166,83 & 155,17 & 512,06 & 203,34 \\
\hline 20 & 181,06 & 99,23 & 206,63 & 285,21 & 126,11 & 165,73 \\
\hline Médias & 172,47 & 212,09 & 189,45 & 265,12 & 318,94 & 282,86 \\
\hline
\end{tabular}




\section{Genitivo}

\begin{tabular}{|c|c|c|c|c|c|c|}
\hline & $\begin{array}{c}\text { Curta } \\
\text { Resumptivo } \\
\text { (C1) }\end{array}$ & $\begin{array}{c}\text { Curta } \\
\text { Lacuna }(\mathbf{C 4})\end{array}$ & $\begin{array}{c}\text { Média } \\
\text { Resumptivo } \\
\text { (C2) }\end{array}$ & $\begin{array}{c}\text { Média } \\
\text { Lacuna (C5) }\end{array}$ & $\begin{array}{c}\text { Longa } \\
\text { Resumptivo } \\
\text { (C3) }\end{array}$ & $\begin{array}{c}\text { Longa } \\
\text { Lacuna (C6) }\end{array}$ \\
\hline 1 & 45,48 & 233,78 & 224,875 & 197,17 & 273,94 & 155,11 \\
\hline 2 & 144,32 & 279,66 & 194,58 & 352,82 & 315,31 & 660,4075 \\
\hline 3 & 262,82 & 218,145 & 235,0325 & 340,495 & 213,63 & 314,0525 \\
\hline 4 & 80,52 & 189,8175 & 96,5425 & 189,33 & 532,2475 & 408,305 \\
\hline 5 & 82,95 & 232,7525 & 228,5675 & 216,9125 & 446,075 & 304,5 \\
\hline 6 & 59,04 & 189,2875 & 346,31 & 300,765 & 237,76 & 178,3 \\
\hline 7 & 88,85 & 211,4525 & 194,4825 & 181,66 & 388,595 & 348,6975 \\
\hline 8 & 214,35 & 334,43 & 366,97 & 262,13 & 281,4575 & 360,5075 \\
\hline 9 & 192,47 & 246,115 & 207,95 & 316,1775 & 373,5625 & 309,1825 \\
\hline 10 & 189,07 & 167,4225 & 240,835 & 333,035 & 327,485 & 441,65 \\
\hline 11 & 124,56 & 180,095 & 370,91 & 216,645 & 234,185 & 289,17 \\
\hline 12 & 218,8475 & 152,615 & 150,1975 & 268,7575 & 158,1875 & 371,885 \\
\hline 13 & 93,3775 & 185,4375 & 138,775 & 257,705 & 331,0675 & 361,435 \\
\hline 14 & 109,7625 & 179,675 & 103,005 & 224,51 & 373,56 & 212,615 \\
\hline 15 & 102,6125 & 195,815 & 135,0175 & 276,955 & 382,35 & 546,075 \\
\hline 16 & 152,7275 & 334,02 & 226,4125 & 514,7775 & 350,765 & 564,56 \\
\hline 17 & 175,245 & 356,6875 & 347,455 & 321,1 & 474,97 & 528,3725 \\
\hline 18 & 97,275 & 278,675 & 253,8175 & 499,86 & 465,265 & 525,8225 \\
\hline 19 & 108,4225 & 180,395 & 119,7725 & 165,8175 & 354,495 & 413,1925 \\
\hline 20 & 116,315 & 157,9825 & 145,8225 & 233,3325 & 298,025 & 457,615 \\
\hline 21 & 82,75 & 112,9975 & 111,865 & 403,9975 & 448,0225 & 676,7925 \\
\hline Médias & 130,56 & 219,87 & 211,39 & 289,24 & 345,76 & 401,35 \\
\hline
\end{tabular}

